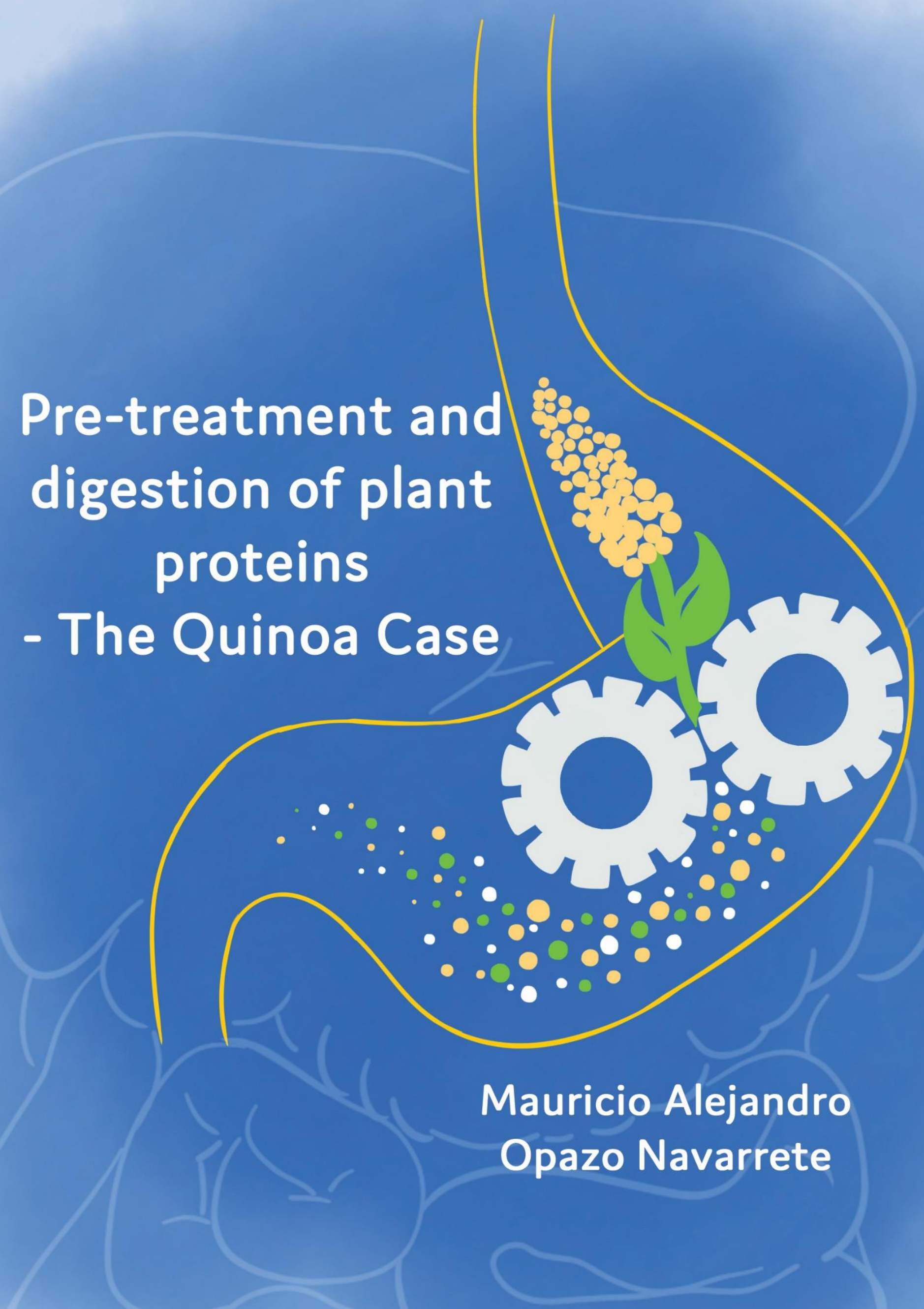




\section{Propositions}

1. Protein digestibility is affected by both high-temperature processing and the presence of starch and fibre.

(this thesis)

2. The design of high-protein food products without a study of the impact of the pre-treatments on the protein digestibility is as much as designing a Ferrari with a two-cylinder engine. (this thesis)

3. Anyone can be a scientist, but to become a good scientist requires more than studying.

4. Before becoming a scientist, you should carefully read the contraindications about it.

5. Good scientists are made of knowledge acquired from their mistakes.

6. It is almost impossible to do a PhD study when having children, but without them, it would be impossible to finish it.

7. The development of more sustainable processes should be a public policy.

8. True science is built between friends and drinks.

Propositions belonging to the thesis entitled:

Pre-treatment and digestion of plant proteins - The quinoa case.

Mauricio Opazo Navarrete

Wageningen, 28 August 2018 


\section{Pre-treatment and digestion of plant proteins - The quinoa case}

Mauricio Opazo Navarrete 


\section{Thesis committee}

\section{Promotor}

Prof. Dr R.M. Boom

Professor of Food Process Engineering

Wageningen University \& Research

\section{Co-promotor}

Dr A.E.M. Janssen

Associate professor, Food Process Engineering

Wageningen University \& Research

\section{Other members}

Prof. Dr G. Tabilo Munizaga, University of Bío Bío, Chillán, Chile

Prof. Dr V. Fogliano, Wageningen University \& Research

Dr A. Sein, DSM Food Specialties BV, Delft

Dr M. Mars, Wageningen University \& Research

This research was conducted under the auspices of the Graduate School VLAG (Advanced studies in Food Technology, Agrobiotechnology, Nutrition and Health Sciences). 


\title{
Pre-treatment and digestion of plant proteins - The quinoa case
}

\section{Mauricio Opazo Navarrete}

\author{
Thesis \\ submitted in fulfilment of the requirements for the degree of doctor \\ at Wageningen University \\ by the authority of the Rector Magnificus, \\ Prof. Dr A.P.J. Mol, \\ in the presence of the \\ Thesis Committee appointed by the Academic Board \\ to be defended in public \\ on Tuesday 28 August 2018 \\ at 4 p.m. in the Aula
}


Mauricio Opazo Navarrete

Pre-treatment and digestion of plant proteins - The quinoa case, 184 pages.

$\mathrm{PhD}$ thesis, Wageningen University, Wageningen, the Netherlands (2018) Which references, with summary in English

ISBN: 978-94-6343-783-7

DOI: https://doi.org/10.18174/451326 


\section{Contents}

Chapter 1. General introduction

Chapter 2. Effect of pre-treatment on in vitro gastric digestion of quinoa protein (Chenopodium quinoa Willd.) obtained by wet and dry fractionation

Chapter 3. Denaturation and in vitro gastric digestion of heat-treated quinoa protein isolates obtained at various extraction $\mathrm{pH}$

Chapter 4. The effect of gel microstructure on simulated gastric digestion of protein gels

Chapter 5. Dry fractionation of quinoa sweet varieties Atlas and Riobamba for sustainable production of protein and starch fractions

Chapter 6. The influence of starch and fibre on in vitro protein digestibility of dry fractionated quinoa (Riobamba variety)

Chapter 7. In vitro protein gastric digestibility of soy and pea protein isolates in relation to their aggregation behaviour

Chapter 8. General discussion

References

Summary

Acknowledgements

About the author

Publications

Training activities 

Chapter 1

General Introduction 


\subsection{Plant proteins}

The global demand for protein-rich foods is expected to double in the coming years, driven by the increasing world population, increasing urbanization, the recognition of the role of protein in a healthy diet, and the combination of an ageing population and the larger need for protein for elderly. The annual global meat production is projected to increase from 218 million tonnes in 1997-1999 to 376 million tonnes by 2030 (WHO, 2003), and it is expected that the growth in demand for animal-sourced food products will strain our natural resources to unsustainable levels. A partial transition from an animal-based diet to a plant-based diet is desirable: the production of meat requires more energy, land, and water resources than the plant-based protein food. Thus, there is an active search plant-based sources of proteins that can replace part of the meat in our diet.

\subsection{Quinoa}

Among plant proteins sources, quinoa (Chenopodium quinoa Willd.) stands out as one of the most interesting. Quinoa has been cultivated in the Andean region of Latin America, in the region of Ecuador, Peru, Bolivia and Chile for thousands of years (Risi \& Galwey, 1984; Tang et al. 2015). In Pre-Columbian times, quinoa was the major crop in Latin America. After the Spanish colonization, its production and consumption were largely replaced by European crops and only remained as part of farmers' traditions (Martínez et al. 2009). Outside that world, quinoa became virtually unknown.

Quinoa could play a significant role in food security due to the great genetic diversity (Li \& Zhu, 2017) and an extraordinary adaptability to grow from sea level to 4000 meters above sea level, at extreme temperatures from -4 to $38{ }^{\circ} \mathrm{C}$ and humidities ranging from $40 \%$ to $88 \%$ (Alan, 2011). It has a high tolerance to adverse environmental conditions such as drought and salinity with low input costs (Jacobsen, 2003). All these features make quinoa a strategic crop for providing nutrition and food security in the face of climate change (Ruiz et al., 2014; FAO, 2014).

Quinoa protein is known to have high nutritional value, having an excellent amino acid balance, which exceeds that of most of the major cereals. The FAO considers it as a perfect food (FAO, 1985). Quinoa proteins are therefore considered promising food ingredients as they can supplement other plant proteins to increase their nutritional value (Abugoch et al., 2008). 
In addition, quinoa, being a gluten-free pseudo-cereal, has attracted the attention for gluten-free diets.

A disadvantage of traditional quinoa is that the seeds contain significant levels of saponins, which give it a bitter taste. Therefore, quinoa needs to be washed using large amounts of water to remove the saponins.

Nowadays, newly bred sweet varieties of quinoa can provide high-quality protein in a more economic and sustainable way than the bitter quinoa varieties: one does not need to rinse out the saponins, which makes post-harvest processing more efficient and resource efficient, while these 'sweet' varieties are better adapted to North West European climates and soils, and may also be adapted to other regions in the world, making local quinoa production possible (Limburg \& Masterbroek, 1997; Masterbroek et al., 2002).

\subsection{Quinoa proteins}

Quinoa seeds have a high protein content of up to about 15\% depending on its variety. Quinoa has two main storage proteins, globulins and albumins, making up 37\% and 35\% of the total protein content, respectively (Vilcacundo \& Hernández-Ledesma, 2017). Prolamins are present in low concentrations (Abugoch, 2009).

The nutritional value of a food is determined by its protein quality, which depends on its amino acid content, its digestibility, the influence of antinutritional factors, and the tryptophan level, relative to the level of larger neutral amino acids (Comai et al., 2007). 
Table 1.1. Essential amino acid profiles of raw quinoa and suggested requirements for adults.

\begin{tabular}{lcc}
\hline \multirow{2}{*}{ Amino acid } & \multicolumn{2}{c}{ Amino acid content (g/100 g protein) } \\
\cline { 2 - 3 } & Quinoa $^{1}$ & FAO/WHO/UNU ${ }^{2}$ \\
\hline Histidine & $1.8-3.4$ & 1.5 \\
Leucine & $2.3-6.8$ & 5.9 \\
Isoleucine & $0.8-4$ & 3 \\
Lysine & $2.4-17.1$ & 4.5 \\
Methionine & $0.3-2.2$ & 1.6 \\
Phenylalanine & $1.5-4.6$ & 3.8 \\
Threonine & $1.5-8.9$ & 2.3 \\
Valine & $0.8-4.8$ & 3.9 \\
Tryptophan & $0.9-1.2$ & 0.6
\end{tabular}

${ }^{1}$ Values derived from the following articles: Elsohaimy et al. (2015), Escudero et al. (2014), USDA (2013) and Johnson \& Aguilera (1980).

${ }^{2}$ Adapted from WHO/FAO/UNU (2007) suggested indispensable amino acid requirements for adults.

Table 1.1 shows that quinoa protein contains high levels of lysine and tryptophan, which are the limiting amino acids in cereals and legumes, respectively. Therefore, quinoa may well be used to complement these crops. In contrast, quinoa is low in sulfuric amino acids methionine and cysteine (Koziol, 1992).

An important index for protein quality is the protein efficiency ratio, which for uncooked quinoa protein is similar to that of casein, while for cooked quinoa protein is $30 \%$ larger than casein (Mahoney et al., 1975; Ranhotra et al., 1993).

Therefore, the effect of processing on the nutritional value needs to be included in any assessment on protein quality.

\subsection{Overview of processing of food proteins}

Processing can alter the nutritional quality of proteins for better or for worse, specially digestibility and bioavailability. In addition, proteins may react with the other components through physical, chemical and enzymatic interaction (Table 1.2). 
Table 1.2. Processing and modifications in food proteins.

\begin{tabular}{|c|c|}
\hline Treatments and interactions & Modifications in food proteins \\
\hline \multicolumn{2}{|l|}{ Physical treatment } \\
\hline Fractionation (pH, leaching) & Change in the amino acid composition \\
\hline \multirow[t]{3}{*}{ Heat treatment } & Denaturation (enzymes, antinutritional factors) \\
\hline & $\begin{array}{l}\text { Destruction of amino acids (desulfuration dehydration, } \\
\text { deamidation) }\end{array}$ \\
\hline & Interaction with food components \\
\hline \multicolumn{2}{|l|}{ Chemical treatment } \\
\hline Alkali $\left(\mathrm{NaOH}, \mathrm{NH}_{3}\right)$ & $\begin{array}{l}\text { Amino acid destruction (cysteine, serine, arginine, } \\
\text { recemization) }\end{array}$ \\
\hline Oxidizing agents $\left(\mathrm{H}_{2} \mathrm{O}_{2}, \mathrm{NaClO}\right)$ & Oxidation of methionine, cysteine, tryptophan \\
\hline Reducing agents $\left(\mathrm{SO}_{2}\right)$ & Sulfocysteine \\
\hline Solvents (chlorinated solvents) & Reaction with cysteine \\
\hline \multicolumn{2}{|l|}{ Interactions with other food components } \\
\hline \multirow[t]{2}{*}{ Proteins } & Isopeptides \\
\hline & Lysinoalanine-lanthionine \\
\hline $\begin{array}{l}\text { Oxidizing molecules (oxygen, lipid oxidation, } \\
\text { polyphenols, pigments) }\end{array}$ & Oxidation of methionine, cysteine, tryptophan \\
\hline Sugars & Maillard reaction \\
\hline \multirow[t]{2}{*}{ Polyphenols } & Reaction with lysine \\
\hline & Oxidation of methionine \\
\hline
\end{tabular}

Adapted from Finot (1983).

The creation of structured solid or semi-solid food relies heavily on the solidification of proteins, by chemical or thermal aggregation. This aggregation has also a large effect on the rate and extend to which these proteins can be digested by humans (Gerrard et al., 2012; Pearce et al., 2007). Depending on the chosen conditions, the pathway of aggregation and the final structure may vary (Lucey, 2002; Foegeding et al., 2006), which can affect the functional properties of the resultant protein network (Lassé, 2013). Also, proteins may be modified chemically during processing (e.g. oxidation) or as a result of reactions with other food ingredients (e.g. Maillard reaction) (Liu et al., 2012). The combination of structural and chemical modifications influence the nutritional value of the proteins (Wang \& Ismail, 2012). These complex relationships among protein structure, chemical modifications and nutritional value are explained schematically in the Figure 1.1. 


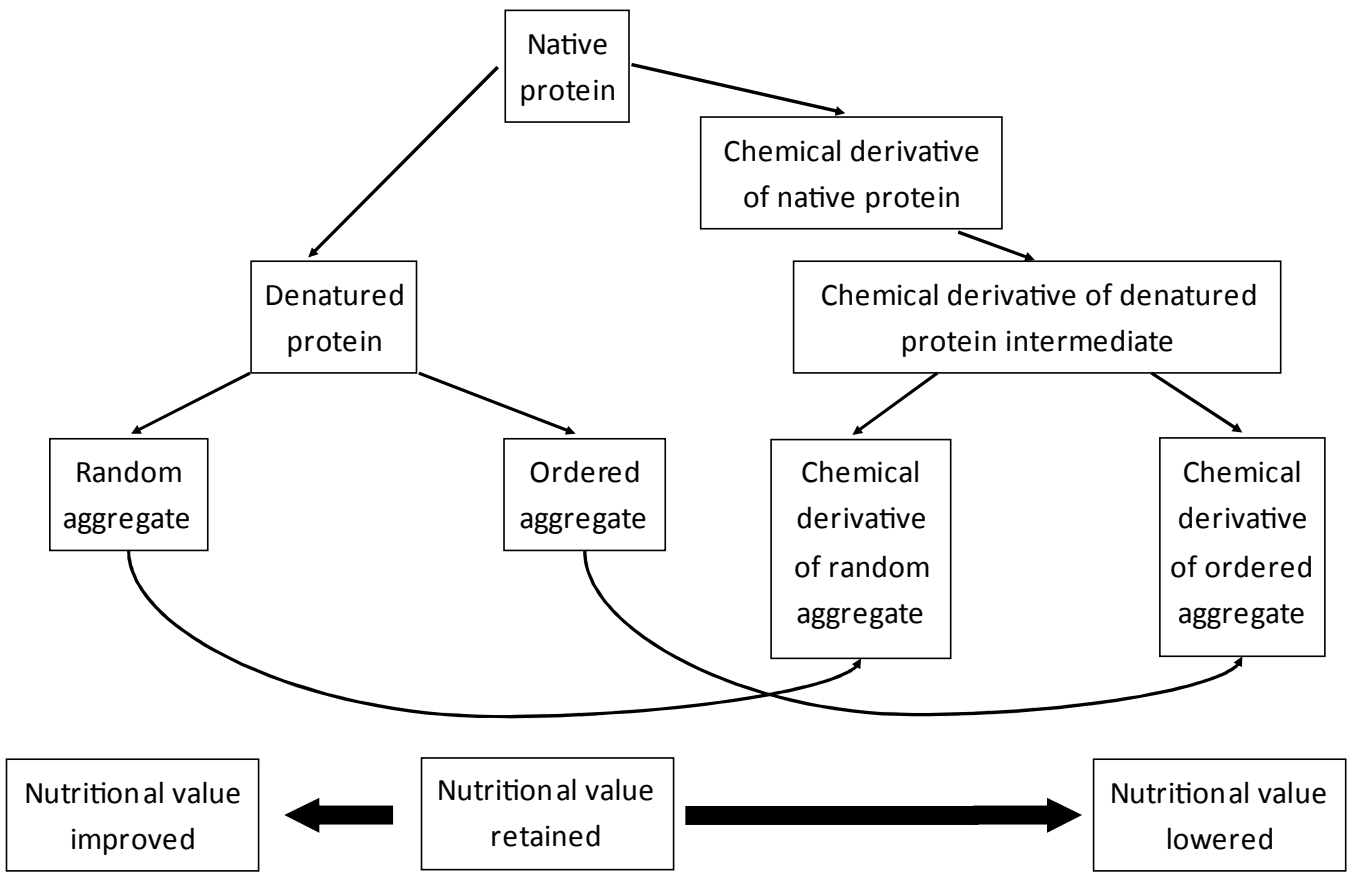

Figure 1.1. Possible interrelationships among food protein structure, protein chemical derivatisation and nutritional value in the final food. Adapted from Gerrard et al. (2012).

As mentioned above, depending on the conditions, the aggregation process can result in random aggregates or in highly ordered structures such as amyloid fibrils (Dobson, 2001). Also, the protein may unfold into an intermediate state, from which it is susceptible for aggregation. The different pathways of protein unfolding and aggregation are shown in Figure 1.2.

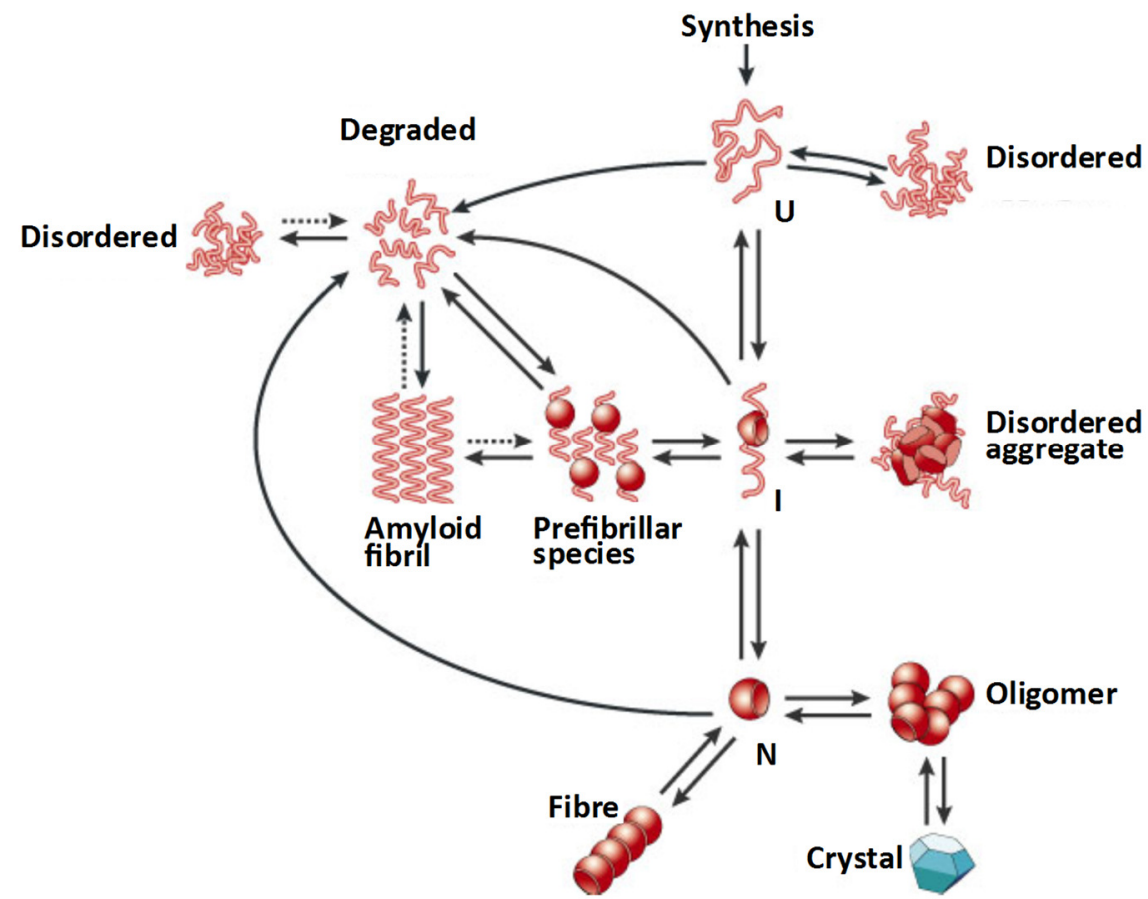

Figure 1.2. Protein aggregation states. $\mathbf{N}$ : native state, $\mathbf{U}$ : protein unfold, I: intermediate state. Adapted from Lassé, (2013) and Dobson (2001). 
Thermal processing is the widely used in the food industry and can significantly affect digestion of proteins (Ruales \& Nair, 1994). Ruales \& Nair (1994) found that cooking at $91{ }^{\circ} \mathrm{C}$ increased the in vitro protein digestibility of quinoa seeds. Shimelis \& Rakshit (2007) found that in vitro protein digestibility of kidney bean was increased after autoclaving. Meanwhile, Hamaker et al. (1986) found that digestibility of sorghum protein decreased significantly after boiling in water for $20 \mathrm{~min}$. The relation between digestibility and heat-induced denaturation is therefore not a simple one and many vary between crops and between different treatments.

\subsection{Protein gastric digestion}

Gastric digestion is a crucial step in the absorption of energy and nutrients from foods (Bornhorst \& Singh, 2014). Protein digestion starts in the stomach and is completed in the small intestine. Protein digestion in the human stomach is facilitated by the presence of acids and protease and subsequently by the pancreatic and intestinal enzymes in the small intestine (Whitney et al., 1998). Two types of gastric digestion can be distinguished; the mechanical digestion by physical division of a mass of food into small masses and chemical digestion by enzyme activity (Figure 1.3). The chemical digestion is catalysed by pepsin, an endopeptidase which is released by chief cells as a zymogen called pepsinogen. In the stomach acid is released from parietal cells. The acid environment is useful to inactivate potential pathogens, to swell the matrix of foods, increasing the accessibility for pepsin, and to improve the digestibility of dietary proteins by further denaturation. It also converts the pepsinogen into pepsin, attaining the most active form of the enzyme at low $\mathrm{pH}(\mathrm{pH} 1.5$ - 3.5). When food is ingested, the vagus nerve and the hormone gastrin are responsible for the trigger of releasing both pepsinogen and $\mathrm{HCl}$ from the stomach lining.

Pepsin is an endopeptidase with a preference for cleavage of peptide bonds involving tryptophan, phenylalanine, tyrosine, methionine, and other amino acids with hydrophobic side chains (Bhagavan, 2002). It does not cleave peptide bonds from valine, alanine and glycine (Sweeny \& Walker, 1993). Protein digestion later continues in the small intestine where trypsin, chymotrypsin and peptidases hydrolyse them into small peptides and amino acids. 


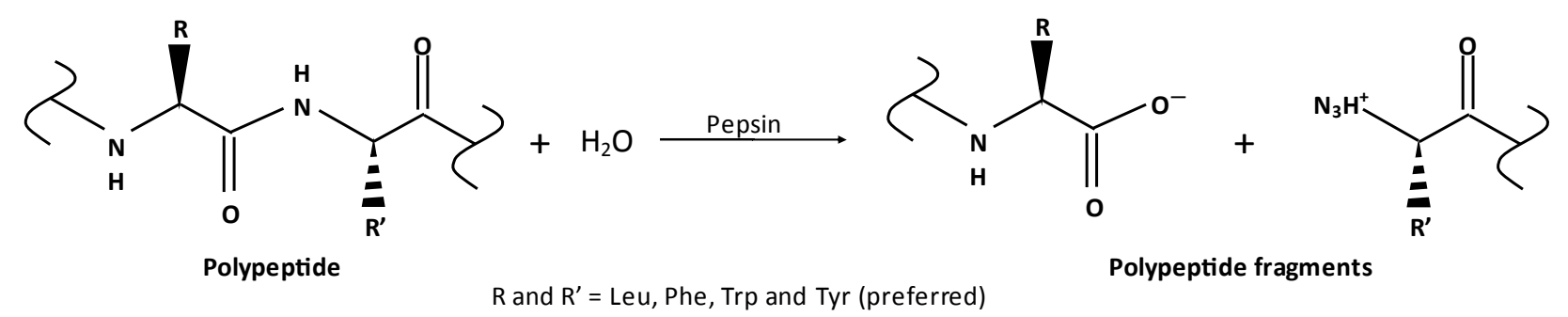

Figure 1.3. Schematic representation of protein hydrolysis by pepsin.

While the ultimate test for digestibility is in in vivo testing in human beings, this is not always the best route. Human studies have many ethical restrictions, which limit the type of testing and conditions that can be employed. Second, the conditions during digestion are different with every individual, and vary over time for every individual. Therefore, in vivo studies are complex for systematic series of experiments. Third, in vivo tests do not allow experiments under simplified conditions, which are very useful in obtaining mechanistic understanding of the digestive process on molecular or colloidal scale.

The breakdown of dietary proteins by the human digestive system therefore also be assessed using in vitro assays that mimic physiological conditions, e.g. $\mathrm{pH}$, temperature, enzyme composition and concentration, among others. Several methods are described in the literature with different scope and aims.

There are as many in vitro digestion protocols as there are published articles in the scientific literature that use them. Digestion conditions can be static, dynamic or a combination. For instance, the $\mathrm{pH}$ may remain constant (static), while digestion is slowly fed in and out of the digestion vessel (dynamic). A constant temperature of $37{ }^{\circ} \mathrm{C}$, is probably one of the few conditions that can be found in most of the research. Other than that, a wide array of conditions is described in the literature. In 2014, an international group of 29 authors reached a consensus that aimed at harmonizing the methodologies for studying in vitro gastrointestinal digestion (Minekus et al., 2014). This document gives detailed recommendations in regard to the composition of simulated digestion fluids, digestion conditions and residence times, among others. One of the downsides of the consensus is that some of the recommended conditions are based on averages which render the methodology too general and inadequate for specific research questions.

The selection of conditions and equipment should serve the research question at hand. Conditions chosen for the assays affect directly enzyme activity and as a consequence, the 
measured digestibility (Dekkers et al., 2016). Table 1.3 presents a brief compendium of parameters that must be considered for a specific gastric digestion study.

Table 1.3. Considerations for the choice of conditions for in vitro digestion assays.

\begin{tabular}{|c|c|c|}
\hline Condition & & Reference \\
\hline Compartments & $\begin{array}{l}\text { Methodologies can focus on a single compartment (mouth, stomach, } \\
\text { small or large intestine), two and up to the full gastrointestinal tract. }\end{array}$ & \\
\hline Gastric pH & $\begin{array}{l}\mathrm{pH} \text { in the gastrointestinal tract depends on the overall health of the } \\
\text { individual, meal volume and composition. The optimal } \mathrm{pH} \text { for maximum } \\
\text { pepsin activity is close to } 2 \text {. Dynamic } \mathrm{pH} \text { models have demonstrated that } \\
\text { the choice of } \mathrm{pH} \text { affects enzyme activity, digestion kinetics and final } \\
\text { digestion. }\end{array}$ & $\begin{array}{l}\text { Minekus et al. (2014) } \\
\text { Dekkers et al. (2016) } \\
\text { Ruiz et al. (2016) }\end{array}$ \\
\hline Ionic strength & $\begin{array}{l}\text { Salts, especially calcium salts, alter enzyme activity. The consensus } \\
\text { proposes a salt buffer composed of } \mathrm{NaCl}, \mathrm{NaHCO}_{3}, \mathrm{KCl}, \mathrm{KH}_{2} \mathrm{PO}_{4} \text {, } \\
\mathrm{CaCl}_{2}\left(\mathrm{H}_{2} \mathrm{O}\right)_{2}, \quad\left(\mathrm{NH}_{4}\right)_{2} \mathrm{CO}_{3}, \mathrm{MgCl}_{2}\left(\mathrm{H}_{2} \mathrm{O}\right)_{6} \text {. Other SGFs reach the } \\
\text { recommended ionic strength only with } \mathrm{NaCl} \text {. }\end{array}$ & $\begin{array}{l}\text { Minekus et al. (2014) } \\
\text { Kong and Singh (2010) }\end{array}$ \\
\hline Enzymes & $\begin{array}{l}\text { Pepsin secretion varies between subjects (generally higher for adults } \\
\text { than for the elderly), external cues and circadian rhythm. The consensus } \\
\text { recommends a meal to SGF ratio of } 1 \text { to } 1 \text {. } \\
\text { Pancreatin is a mix of trypsin, chymotrypsin and other proteases, } \\
\text { commonly used for the intestinal phase. }\end{array}$ & $\begin{array}{l}\text { Minekus et al. (2014) } \\
\text { Luo et al. (2017) }\end{array}$ \\
\hline $\begin{array}{l}\text { Accompanying } \\
\text { substances }\end{array}$ & $\begin{array}{l}\text { The use of phospholipids and bile salts is advised in the consensus, these } \\
\text { become increasingly important for complex food matrices or if } \\
\text { gastrointestinal digestion will be studied. } \\
\text { The downside of incorporating proteic compounds such as mucin to the } \\
\text { digestion mix is that they can by hydrolysed and may cause to } \\
\text { overestimate digestibility. }\end{array}$ & $\begin{array}{l}\text { Minekus et al. (2014) } \\
\text { Kong and Singh (2010) }\end{array}$ \\
\hline Peristalsis & $\begin{array}{l}\text { Motion within the compartments of the gastrointestinal tract can be } \\
\text { simulated by continuous magnetic stirring. Closer approximations to } \\
\text { gastric motion have been developed, these are especially useful for the } \\
\text { disintegration of solid foods. }\end{array}$ & $\begin{array}{l}\text { Kong and Singh (2010) } \\
\text { Ruiz et al. (2016) }\end{array}$ \\
\hline Transit & $\begin{array}{l}\text { Some advanced dynamic models, including TNO's gastrointestinal } \\
\text { model TIM, allow controlling the secretion of digestive fluids into the } \\
\text { system as well as the emptying rate of each compartment. The use of } \\
\text { these systems is desirable in late stages of research, once understanding } \\
\text { of digestion within individual compartments has been achieved. }\end{array}$ & Minekus (2015) \\
\hline
\end{tabular}

Among these, the $\mathrm{pH}$ in the gastrointestinal tract is of prime importance. When the meal reaches the stomach, the $\mathrm{pH}$ in the stomach increases due to the buffering capacity of the meal, and is then slowly reduced again as $\mathrm{HCl}$ is being secreted in the gastric juice. While the optimal $\mathrm{pH}$ 
for pepsin activity is close to 2, the consensus as described by Minekus et al. (2014) recommends a $\mathrm{pH}$ of 3 as represents a "mean value for a general meal". It is clear however that the contents of the stomach not have $\mathrm{pH} 3$ during most of the gastric digestion time.

The dosage of the enzymes is another important parameter. While enzyme secretion varies strongly between groups and between individuals, the consensus recommends a ratio of 1:1 between the meal and SGJ. However, the amount of secreted enzymes varies greatly depending on the type and size of the meal. We consider the protein-to-enzyme ratio to be better suited for the study of protein digestibility.

\subsection{Research aim}

The overall objective of the work described in this thesis was to obtain understanding of the effect of processing of plant proteins, mainly quinoa, on the in vitro gastric protein digestibility. While different proteins were investigated, one of the prime protein sources was quinoa, due to its potential. Different processing methods were compared, including dry milling, which avoids any hydration or heating during processing. In addition the influence of the state of the product was investigated: as dissolved or dispersed protein in solution, or as protein gel. The digestibility was assessed with in vitro essays, to maximise the reproducibility and to allow conditions that allow mechanistic conclusions by avoiding too much complexity.

\subsection{Thesis outline}

This thesis is on the in vitro gastric digestibility of plant protein and more specific on quinoa.

Chapter 2 explores how the method of extraction used to isolate or concentrate quinoa protein and the preheating of proteins at different temperatures affect the protein digestibility.

Chapter 3 presents a study of the thermal properties, protein aggregation and in vitro gastric digestibility of unheated and pre-heated quinoa protein suspensions obtained at various extraction $\mathrm{pH}$. The protein yield and purity obtained after the extraction were determined. The in vitro gastric protein digestibility of unheated and pre-heated quinoa protein suspensions was assessed and compared to that of the quinoa protein isolates.

Chapter 4 analyses the impact on the protein gastric digestibility of the gel structure obtained at different temperatures prepared from soy protein isolate, pea protein concentrate, albumin from chicken egg white and whey protein isolate. The influence of temperature on the 
microstructure was evaluated. The in vitro gastric digestion of gels was evaluated via OPA method and HPSEC analysis.

Chapter 5 evaluate dry milling and subsequent sieving as an alternative to the conventional wet extraction of quinoa proteins and starch from two sweet quinoa varieties. The fractions obtained were characterized according to the proximate composition. Some functional properties of the quinoa fractions were evaluated.

Chapter 6 investigates the effect of quinoa starch and fibre on the in vitro gastric digestibility of quinoa protein. A sweet variety called Riobamba was used in this study. In turn, the protein digestibility of quinoa protein concentrate obtained via a dry fractionation method was compared with quinoa protein isolate extracted via a wet fractionation method. The quinoa samples were analysed prior and after preheating.

Chapter 7 provides an better understanding of the role of heat-induced aggregation on the protein digestibility of soy and pea proteins. The heat-induced aggregates were characterised and its impact on molecular weight distribution was evaluated. The in vitro gastric digestibility and protein hydrolysis were evaluated according to the OPA method and HPSEC analysis, respectively.

Chapter 8 provides a general discussion and overall evaluation and gives a perspective on the future of the research into and application of the digestibility plant proteins.

\subsection{References}

Abugoch, J.L.E. (2009). Quinoa (Chenopodium quinoa Willd.): composition, chemistry, nutritional, and functional properties. Advances in Food Nutrition Research, 58, 1-31.

Abugoch, L.E., Romero, N., Tapia, C.A., Silva, J., \& Rivera, M. (2008). Study of some physicochemical and functional properties of quinoa (Chenopodium quinoa Willd.) protein isolates. Journal of Agricultural and Food Chemistry, 56,4745-4750.

Alan, B. (2011). Quinoa, an ancient crop to contribute to world food security. In $37^{\text {th }}$ FAO conference.

Bhagavan, N.V. (2002). Chapter 12 - Gastrointestinal Digestion and Absorption, in Medical Biochemistry (Fourth Edition). Academic Press: San Diego, pp. 197-224. 
Bornhorst, G.M., \& Singh, R.P. (2014). Gastric Digestion In Vivo and In Vitro: How the Structural Aspects of Food Influence the Digestion Process. Annual Review of Food Science and Technology, 5, 111-132.

Comai, S., Bertazzo, A., Bailoni, L., Zancato, M., Costa, C., \& Allegri, G. (2007). The content of proteic and nonproteic (free and protein-bound) tryptophan in quinoa and cereal flours. Food Chemistry, 100, 1350-1355.

Dekkers, B.L., Kolodziejczyk, E., Acquistapace, S., Engman, J., \& Wooster, T.J. (2016). Impact of gastric $\mathrm{pH}$ profiles on the proteolytic digestion of mixed $\beta$ lg-Xanthan biopolymer gels. Food \& Function, 7(1), 58-68.

Dobson, C.M. (2001). The structural basis of protein folding and its links with human disease. Philosophical Transactions of the Royal Society of London, 356(1406), 133-145.

Elsohaimy, S.A., Refaay, T.M., \& Zaytoun, M.A.M. (2015). Physicochemical and functional properties of quinoa protein isolate. Annals of Agricultural Science, 60(2), 297-305.

Escudero, O., González-Martín, M.M., Wells, G., Fisher, S., \& Hernández-Hierro, J.M. (2014). Amino acid profile of the quinoa (Chenopodium quinoa Willd.) using near infrared spectroscopy and chemometric techniques. Journal of Food Cereal Science, 60, 67-74.

Finot, P.A. (1983). Influence of processing on the nutritional value of proteins. Plant Foods for Human Nutrition, 32, 439-453.

Foegeding, E.A., Luck, P.J. \& Davis, J.P. (2006). Factors determining the physical properties of protein foams. Food Hydrocolloids, 20(2-3), 284-292.

Food and Agriculture Organization (FAO) (1985). Food and Agriculture Organization of the United States/World Health Organization/United Nations University, Energy and Protein Requirement Report of a joint FAO/WHO/UNU meeting. World Health Organization, Geneva.

Food and Agriculture Organization (FAO) (2014). Assessment of the international year of quinoa 2013. Hundred and forty-ninth session. CL 149/10. Rome, Italy.

Gerrard, J.A., Lasse, M., Cottam, J., Healy, J.P., Fayle, S.E., Risiah, I., Brown, P.K., BinYasir, S.M., Sutton, K.H., \& Larsen, N.G. (2012). Aspects of physical and chemical alterations 
to proteins during food processing - some implications for nutrition. British Journal of Nutrition, 108, S288-S297.

Hamaker, B.R., Kirlesi, A.W., Mertz, E.T., \& Axtell, J.D. (1986). Effect of Cooking on the Protein Profiles and in Vitro Digestibility of Sorghum and Maize. Journal of Agricultural and Food Chemistry, 34, 647-649.

Jacobsen, S. E. (2003). The worldwide potential for quinoa (Chenopodium quinoa Willd.). Food Reviews International, 19, 167-177.

Johnson, R., \& Aguilera, R. (1980). Processing varieties of oilseeds (Lupine and Quinoa). In Report to natural fibres and foods commission of Texas, 1978-1980 (Reported by D. Cusack, 1984, The Ecologist, 14, 21-31).

Kong, F., \& Singh, R.P. (2010). A human gastric simulator (HGS) to study food digestion in human stomach. Journal of food science, 75(9), 627-635.

Koziol, M. (1992). Chemical composition and nutritional evaluation of quinoa (Chenopodium quinoa Willd.). Journal of Food Composition and Analysis, 5, 35-68.

Lassé, M. (2013). Does the Protein Aggregation State Affect the Digestibility and Safety of Foods?. PhD Thesis. University of Canterbury.

Li, G., \& Zhu, F. (2017). Quinoa starch: Structures, properties, and applications. Carbohydrate Polymers, 181, 851-861.

Limburg, H., Masterbroek, H.D. (1997). Breeding high yielding lines of Chenopodium quinoa Willd. with saponin free seed. In: Stølen, O., Bruhn, K., Pithan, K., \& Hill, J. (eds) Amall Grain Cereals and Pseudo-Cereals. Proc. COST 814 workshop, 22-24 February 1996, Copenhagen, Denmark, pp. 103-114.

Liu, J., Ru, Q., \& Ding, Y. (2012). Glycation a promising method for food protein modification: physicochemical properties and structure, a review. Food Research International, 49(1), $170-183$.

Lucey, J.A. (2002). Formation and physical properties of milk protein gels. Journal of Dairy Science, 85(2), 281-294. 
Luo, Q., Borst, J.W., Westpha;, A.H., Boom, R.M., \& Janssen, A.E.M. (2017). Pepsin diffusivity in whey protein gels and its effect on gastric digestion. Food Hydrocolloids, $66,318-325$.

Mahoney, A., Lopez, J., \& Hendricks, D. (1975). Evaluation of the protein quality of quinoa. Journal of Agricultural and Food Chemistry, 23(2), 190-193.

Minekus, M. (2015). The TNO Gastro-Intestinal Model (TIM), in The Impact of Food Bioactives on Health: in vitro and ex vivo models. In: Verhoeckx, K., Cotter, K., LópezExpósito, I., Kleiveland, C., Lea, T., Mackie, A., Requena, T., Swiatecka, D., \& Wichers, H. (eds). Springer International Publishing: Cham., pp. 37-46.

Minekus, M., Alminger, M., Alvito, P., Ballance, S., Bohn, T., Bourlieu, C., Carrière, F., Boutrou, R., Corredig, M., Dupont, D., Dufour, C., Egger, L., Golding, M., Karakaya, S., Kirkhus, B., Le Feunteun, S., Lesmes, U., Macierzanka, A., Mackie, A., Marze, S., McClements, D.J., Ménard, O., Recio, I., Santos, C.N., Singh, R.P., Vegarud, G.E., Wickham, M.S., Weitschies, W., \& Brodkorb, A. (2014). A standardised static in vitro digestion method suitable for food - an international consensus. Food \& Function, 5(6), 1113-1124.

Martínez, E.A., Veas, E., Jorquera, C., San Martín, R., \& Jara, P. (2009). Re-introduction of Quinoa into arid Chile: cultivation of two lowland races under extremely low irrigation. Journal of Agronomy and Crop Science, 195, 1-10.

Pearce, F.G., Mackintosh, S.H. \& Gerrard, J.A. (2007). Formation of amyloid-like fibrils by ovalbumin and related proteins under conditions relevant to food processing. Journal of Agricultural and Food Chemistry, 55(2), 318-322.

Ranhotra, G., Gelroth, J., Glaser, B., Lorenz, K., \& Johnson, D. (1993). Composition and protein nutritional quality of quinoa. Cereal Chemistry Journal, 70(3), 303-305.

Risi, C.J., \& Galwey, N.W. (1984). The Chenopodium grains of the Andes: Inca crops for modern agriculture. Advances in Applied Biology, 10, 145-216.

Ruales, J., \& Nair, B.M. (1994). Effect of processing on in vitro digestibility of protein and starch in quinoa seeds. International Journal of Food Science \& Technology, 29(4), $449-56$. 
Ruales, J., \& Nair, B. (1992). Nutritional quality of the protein in quinoa (Chenopodium quinoa Willd) seeds. Plant Foods for Human Nutrition, 42, 1-11.

Ruiz, G.A., Opazo-Navarrete, M., Meurs, M., Minor, M., Sala, G., van Boekel, T., Stieger, M., \& Janssen, A.E.M. (2016). Denaturation and in Vitro Gastric Digestion of Heat-Treated Quinoa Protein Isolates Obtained at Various Extraction pH. Food Biophysics, 11, 184197.

Ruiz, K.B., Biondi, S., Oses, R., Acuña-Rodríguez, I.S., Antognoni, F., Martinez-Mosqueira, E.A., Coulibaly, A., Canahua-Murillo, A., Pinto, M., Zurita-Silva, A., Bazile, D., Jacobsen, S.-E., \& Molina-Montenegro, M.A. (2014). Quinoa biodiversity and sustainability for food security under climate change. A review. Agronomy for Sustainable Development, 34(2), 349-359.

Shimelis, E.A., \& Rakshit, S.K. (2007). Effect of processing on antinutrients and in vitro protein digestibility of kidney bean (Phaseolus vulgaris L.) varieties grown in East Africa. Food Chemistry, 103, 161-172.

Tang, Y., Li, X., Zhang, B., Chen, P.X., Liu, R., \& Tsao, R. (2015). Characterisation of phenolics, betanins and antioxidant activities in seeds of three Chenopodium quinoa Willd. genotypes. Food Chemistry, 166, 380-388.

U.S. Department of Agriculture, Agricultural Research Service. (2013). USDA national nutrient database for standard reference, release 26. Nutrient Data Laboratory, Beltsville Human Nutrition Research Center, Agriculture Research Service, United States Department of Agriculture. Retrieved from Nutrient Data Laboratory Home Page, http://www.ars.usda.gov/ba/bhnrc/ndl.

Vilcacundo, R., \& Hernandez-Ledesma, B. (2017). Nutritional and biological value of quinoa (Chenopodium quinoa Willd.). Current Opinion in Food Science, 14, 1-6.

WHO/FAO/UNU (2007). Protein and amino acid requirements in human nutrition. Report of a joint WHO/FAO/UNU expert consultation, Geneva, Switzerland.

WHO (2003). Diet, nutrition and the preventing of chronic diseases. WHO Technical Report Series, Geneva, Switzerland. 
Chapter 1

Whitney, E.N., Cataldo, B.C., \& Sharon, R.R. (1998). Understanding normal and clinical nutrition. 5th ed. Belmont, USA: Wadsworth Publishing Company Inc. 


\section{Chapter 2}

Effect of pre-treatment on in vitro gastric digestion of quinoa protein (Chenopodium quinoa Willd.) obtained by wet and dry fractionation

This chapter has been published as: Opazo-Navarrete, M., Schutyser, M.A.I., Boom, R.M. \& Janssen, A.E.M. (2017). Effect of pre-treatment on in vitro gastric digestion of quinoa protein (Chenopodium quinoa Willd.) obtained by wet and dry fractionation. International Journal of Food Sciences and Nutrition, 69(1), 1-11. 


\subsection{Abstract}

Quinoa protein was isolated from quinoa seeds using wet fractionation that resulted in a protein isolate (QPI) with a high protein purity of $87.1 \%(\mathrm{w} / \mathrm{dw})$ and a protein yield of around $54 \%$, and a dry fractionation method delivered a quinoa protein concentrate (QPC) with a purity of $27.8 \%(\mathrm{w} / \mathrm{dw})$ and yield of around $47 \%$. The dry fractionation process only involves milling and sieving and keeps the protein in its natural, native state. The aim was to study the in vitro gastric digestibility of both protein. Attention was paid to thermal pre-treatment of QPI and QPC. QPC showed significantly higher $(\mathrm{p}<0.05)$ digestibility than QPI samples. The results were interpreted with a simple double exponential model. The fraction of easily digested protein in QPC is higher than for QPI. The better digestibility of the QPC was explained by the prevention of the formation of large aggregates during pre-heating of the protein. 


\subsection{Introduction}

Quinoa (Chenopodium quinoa Willd.) has been cultivated in the Andean region of Latin America for thousands of years (Tang et al., 2015). Its production was largely replaced by European crops after the Spanish conquest (Martínez et al., 2009). Nowadays, there is a renewed interest worldwide in quinoa due to its high nutritional value, especially the essential amino acid balance. Quinoa proteins are therefore considered promising food ingredients as they can supplement other plant proteins to increase their nutritional value (Abugoch et al., 2008). In addition, quinoa, being a gluten-free pseudo-cereal, has attracted the attention of gluten-free manufacturers.

Traditionally, wet fractionation has been used to obtain protein-rich fractions. During this process, the starting material is reduced in size and subsequently diluted to achieve complete disentanglement of the tissue structures to allow extraction of individual or classes of components as proteins, starch and lipids (Schutyser \& van der Goot, 2011). This process is not only energy intensive, but also affects the functionality of the protein (Pelgrom et al., 2014). Dry fractionation is a more sustainable alternative to wet fractionation for quinoa seeds. During dry fractionation, a protein-enriched fraction can be obtained by milling and dry separation by for example, sieving or air classification. This delivers a protein fraction that is still in its natural state. A disadvantage of this technique is the lower protein purity that can be obtained in the concentrate.

While the amino acid profile including the essential amino acids is important for the nutritive quality of a protein source, its digestibility is another important factor in determining the quality of a protein source (FAO/WHO/UNU, 2007). Generally, the potential use of plant proteins and thus also quinoa protein as a food ingredient is limited by their relatively lower digestibility as compared with animal proteins (Guillaume et al., 2001).

Protein digestion in the human stomach is facilitated by the presence of acids and pepsin and subsequently by the pancreatic and intestinal enzymes in the small intestine (Whitney et al., 1998). Heating often leads to an increase in digestibility. For example, heat treatment of sweet potato protein isolate (PPI) at $100{ }^{\circ} \mathrm{C}(20$ and $60 \mathrm{~min}), 110$ and $127{ }^{\circ} \mathrm{C}$ for $20 \mathrm{~min}$ resulted in a significant increase in the gastrointestinal digestibility compared to that of native protein (Sun et al., 2012). Whey protein isolate (WPI) heat treated at $80{ }^{\circ} \mathrm{C}$ for $30 \mathrm{~min}$ significantly enhanced its gastric digestibility compared with native WPI (He et al., 2013). However, heating can also 
result in a decrease of the digestibility. Heating soy protein isolate (SPI) at $100{ }^{\circ} \mathrm{C}$ for $60 \mathrm{~min}$ decreased its gastric digestibility compared with native SPI (Sun et al., 2012).

In vitro assays simulating digestion processes have been used to study the effect of temperature on quinoa protein isolate (Avila et al., 2016a) and quinoa seeds (Ruales \& Nair, 1992). However, the in vitro gastric digestion of quinoa protein concentrate in solution has not been studied before. Since the fractionation processes to obtain quinoa protein isolate (QPI) and quinoa protein concentrate (QPC) are different, there may be differences in the digestibility of the protein fractions.

The aim of this paper is to study in vitro gastric digestion of the untreated protein fractions as well as heat-treated protein fractions in solution. Both QPI and QPC will be studied. We hypothesise that QPC, where the protein is in its natural, native state, is more digestible as compared to QPI, where the protein properties may have changed due to the harsh conditions during the wet fractionation process.

\subsection{Materials and methods}

\subsubsection{Materials}

Quinoa (Chenopodium quinoa Willd.) with a protein content of $11.6 \%(\mathrm{w} / \mathrm{dw})$ purchased from Notenstore (The Netherlands). Pepsin from porcine gastric mucosa (400 - 800 units/mg, P7125), mucin from porcine stomach (Type III, M2378-100 G) and all other chemicals were purchased from Sigma-Aldrich Inc. (St. Louis, MO). Milli-Q water $\left(18.2 \mathrm{MX} \mathrm{cm}\right.$ at $25{ }^{\circ} \mathrm{C}$, Millipore Corporation, Molsheim, France) was used for all experiments.

\subsubsection{Wet fractionation method}

The wet fractionation method was carried out according to Avila et al. (2016a) with minor modifications. Quinoa seeds were pre-milled with a laboratory scale mill (Fritsch Mill Pulverisette 14, Indar-Oberstein, Germany) at 7,000 rpm and sieved through a $200 \mu \mathrm{m}$ sieve. Oil extraction was performed in a Soxhlet for $24 \mathrm{~h}$ using petroleum ether as solvent. The defatted flour was suspended in deionised water $(10 \% \mathrm{w} / \mathrm{w})$ and the $\mathrm{pH}$ was adjusted to 8 by addition of $2 \mathrm{~N} \mathrm{NaOH}$. The extraction was performed at room temperature for $4 \mathrm{~h}$. The suspensions were centrifuged for $30 \mathrm{~min}$ at $6000 \mathrm{~g}$ and $10{ }^{\circ} \mathrm{C}$. The supernatants were then acidified to $\mathrm{pH} 4.5$ by addition of $2 \mathrm{~N} \mathrm{HCl}$ and incubated at room temperature for $1 \mathrm{~h}$. The suspensions were centrifuged for $30 \mathrm{~min}$ at $13,000 \mathrm{xg}$ and $10^{\circ} \mathrm{C}$. The precipitated pellets were 
re-suspended in deionised water $(5 \% \mathrm{w} / \mathrm{w})$. To rinse remaining salts the suspensions were centrifuged twice for $30 \mathrm{~min}$ at $13000 \mathrm{xg}$ and $10{ }^{\circ} \mathrm{C}$, re-suspended in deionised water $(5 \% \mathrm{w} / \mathrm{w})$ and neutralised by addition of $2 \mathrm{~N} \mathrm{NaOH}$. The suspensions were frozen overnight and subsequently freeze-dried for $72 \mathrm{~h}$ (Chris Epsilon 2-6D Freeze Dryer, Osterode am Harz,Germany). The dried protein isolates were mixed and ground with an IKA A11 basic grinder (IKA-Werke GmbH and Co., Staufen, Germany) for a few seconds to obtain powders.

\subsubsection{Dry fractionation method}

Quinoa seeds were pre-milled to separate the cotyledons from the seed with a laboratory scale mill (Fritsch Mill Pulverisette 14, Idar-Oberstein, Germany) with a 1.5 and $2.0 \mathrm{~mm}$ screen at room temperature. The rotor speed was $6,000 \mathrm{rpm}$ with a feed rate of $\sim 20 \mathrm{~g} / \mathrm{min}$. The milling experiments were performed in triplicate.

The pre-milled quinoa seeds were sieved by air jet sieving (Alpine200 LS-N, HosokawaAlpine, Augsburg, Germany) with different sieves (1, 0.85, 0.63, 0.5 and $0.315 \mathrm{~mm})$ at 1,500 Pa for 2.5 min. During these sieving experiments, each time a sample of $25 \mathrm{~g}$ of pre-milled seeds was sieved. The protein separation efficiency was measured as the percentage of protein in each fraction. All experiments were performed in triplicate. The fraction with the highest protein content was chosen for gastric digestion analysis.

\subsubsection{Determination of protein content}

The protein content was measured by Dumas analysis (Nitrogen analyser, FlashEA 1112 series, Thermo Scientific, Interscience, Breda, The Netherlands). A conversion factor of $\mathrm{N}$ x 6.25 for quinoa protein was used (Ruales \& Nair 1994; Nascimento et al. 2014). Protein purity was defined as mass protein/mass dry matter $(\mathrm{w} / \mathrm{dw})$. The measurements were carried out in triplicate. All protein contents reported are based on dry matter basis.

\subsubsection{Heat treatment of quinoa protein solutions}

All solutions were prepared by dissolving $0.1 \mathrm{~g}$ of pure quinoa protein in $2 \mathrm{~mL}$ of solution with Milli-Q water, prepared at room temperature into an Eppendorf tube of $2 \mathrm{~mL}$. The solutions were stirred vigorously using a stirrer for $30 \mathrm{~min}$. Subsequently, the solutions were subjected to heat treatment at 60 and $90{ }^{\circ} \mathrm{C}, 30 \mathrm{~min}$ and 1,400 rpm of shaking in a pre-heated Eppendorf thermomixer (Eppendorf AG, Hamburg, Germany). Heat treatment at $120{ }^{\circ} \mathrm{C}$ during $30 \mathrm{~min}$ was carried out without shaking in a heating block (Grant QBT4, Cambridge, UK). After 
heating, the samples were immediately cooled and kept at room temperature until measurement the same day.

\subsubsection{In vitro gastric digestion of quinoa protein}

The suspensions of 5\% protein (w/v, in Milli-Q water) were incubated in the simulated gastric juice at $37^{\circ} \mathrm{C}$ for $6 \mathrm{~h}$. The simulated gastric juice was prepared according to Luo et al. (2015). For this, pepsin $(1 \mathrm{~g} / \mathrm{L})$, mucin $(1.5 \mathrm{~g} / \mathrm{L})$ and $\mathrm{NaCl}(8.775 \mathrm{~g} / \mathrm{L})$ were dissolved in Milli-Q water and the $\mathrm{pH}$ was adjusted to 2.0. The enzyme:substrate ratio during all experiment was constant at $1: 2$ (weight/weight).

The quinoa suspension was added to $50 \mathrm{~mL}$ of simulated gastric juice in a jacketed glass vessel connected to a water bath of $37{ }^{\circ} \mathrm{C}$ (Julabo $\mathrm{GmbH}$, Seelbach, Germany). The solution was stirred at $100 \mathrm{rpm}$ and the vessel was sealed with Parafilm (Pechiney Plastic Packaging Inc., IL) to avoid evaporation. Samples were taken at 5, 10, 20, 30, 60, 90, 120, 180, 240 and 360 min for further analyses. Immediately after sampling, the samples were heated in a pre-heated Eppendorf thermomixer (Eppendorf AG, Hamburg, Germany) at $90{ }^{\circ} \mathrm{C}$ and $1,400 \mathrm{rpm}$ for 5 min to inactivate the pepsin, which is rapidly inactivated at a temperature above $62{ }^{\circ} \mathrm{C}$ (Casey \& Laidler, 1951). All digestion experiments were performed in triplicate.

\subsubsection{Effect of starch concentration on digestibility}

Because starch is the main component in the dry fractionated protein concentrate, the effect of starch was evaluated. The effect of starch on protein digestibility was measured using two different ratios of protein and starch. Starch is obtained by the dry fractionation method (fraction $>1 \mathrm{~mm}$ ). The suspensions with $5 \%$ of protein (w/v, in Milli-Q water) were used and starch was added. Solutions of QPI with $20 \%$ and $50 \%$ of starch added were used. These solutions were heated at 90 and $120^{\circ} \mathrm{C}$ for $30 \mathrm{~min}$ and the protein digestibility was measured. All measurements were carried out in triplicate.

\subsubsection{Size exclusion chromatography (SEC)}

In vitro digested samples were analysed via high-performance size-exclusion chromatography using an Ultimate 3000 UHPLC system (Thermo Scientific, MA) equipped with a TSKgel G2000SWX1 column (7.8mm x $300 \mathrm{~mm}$ ) (Tosoh Bioscience LLC, PA). For analysis $0.5 \mathrm{~mL}$ of undiluted sample was filtered using a $0.22 \mathrm{~lm}$ filter. A $10 \mu \mathrm{L}$ sample was injected each time. The mobile phase was acetonitrile (30\%) in Milli-Q water (70\%) containing trifluoroacetic acid 
$(0.1 \%)$. The flow rate was $1 \mathrm{~mL} / \mathrm{min}$ and the UV detector was set at $214 \mathrm{~nm}$. Calibration was carried out with: carbonic anhydrase $(29 \mathrm{kDa}), \alpha$-lactalbumin $(14.1 \mathrm{kDa})$, aprotinin $(6.51 \mathrm{kDa})$, insulin $(5.7 \mathrm{kDa})$, bacitracin $(1.42 \mathrm{kDa})$ and phenylalanine (165 Da) (Sigma-Aldrich Inc., St. Louis, MO). The molecular mass was estimated based on the elution time of molecular weights markers. All measurements were carried out in triplicate.

\subsubsection{Degree of hydrolysis (DH)}

The degree of hydrolysis was measured using the OPA method (Nielsen et al., 2001) in order to determine the degree of hydrolysis attained. The OPA reagent $(100 \mathrm{~mL})$ was prepared by dissolving $3.81 \mathrm{~g}$ sodium tetraborate decahydrate (Borax) and $0.1 \mathrm{~g}$ of sodium dodecyl sulphate (SDS) in $80 \mathrm{~mL}$ Milli-Q water. o-Phthaldialdehyde (OPA), $80 \mathrm{mg}$ dissolved in $2 \mathrm{~mL}$ ethanol, was added to the Borax-SDS solution together with $88 \mathrm{mg}$ of dithiothreitol (DTT). The solution was filled up to $100 \mathrm{~mL}$ with milli-Q water and filtered over a $0.45 \mu \mathrm{m}$ filter. The solution was stored in a bottle covered with aluminium foil because OPA reagent is sensitive to light.

A standard curve was prepared using L-serine in a concentration range of $50-200 \mathrm{mg} / \mathrm{L}$ (Nielsen et al., 2001). The OPA assay was carried out by the addition of $200 \mu \mathrm{L}$ of sample (or standard) to $1.5 \mathrm{~mL}$ of OPA reagent. The samples were pipetted into the Amicon Ultra- $0.510 \mathrm{~K}$ Centrifugal Filter Units (Millipore) and centrifuged for $20 \mathrm{~min}$ at 14,000 g. The absorbance of these solutions was measured after 3 minutes at $340 \mathrm{~nm}$ with a spectrophotometer DU 720 (Beckman Coulter Inc., Pasadena, CA). Free amino groups in quinoa protein digest were expressed as serine amino equivalents (Serine NH2). The DH was calculated using the following equations (2.1) and (2.2):

$D H=\frac{h}{h_{t o t}} \cdot 100$

Equation 2.1

$h=\frac{\left(\text { Serine } \mathrm{NH}_{2}-\beta\right)}{\propto}$

Equation 2.2

Where, the value of constants $\alpha$ and $\beta$ used here are the values reported by Adler-Nielsen (1986), $\alpha$ equal 1 and $\beta$ equal 0.4. While $h_{\text {tot }}$ was estimated according to the concentration of each amino acid present in the protein (Lindeboom, 2005) and found to be 7.4 mequv/g for quinoa protein. All measurements were carried out in triplicate.

\subsubsection{Scanning Electron Microscope}


The images of quinoa fractions were obtained by scanning electron microscopy (Phenom G2 Pure, Phenom- World BV, Eindhoven, The Netherlands). Carbon tabs (SPI Supplies/Structure Probe Inc., West Chester, PA) were used to fix the samples on aluminium pin mounts (SPI Supplies/Structure Probe Inc., West Chester, PA). Pre-treatment of the samples was not necessary.

\subsubsection{Particle size distribution}

Particle size distribution of QPI samples unheated and heated at 60, 90 and $120 \mathrm{C}$ for $30 \mathrm{~min}$ was measured using a Mastersizer 2000 (Malvern Instruments Ltd., Worcestershire, UK). Before the measurements were taken, the samples were diluted to $2 \%$ at $\mathrm{pH} 2$. A refractive index of 1.45 was used for the dispersed phase and 1.33 for the continuous phase (water). Samples were diluted in milli-Q water in the measurement cell of the equipment until the obscuration reached $15 \%$ for the digested samples. The mean particle sizes and distribution were determined as the average of three repeated measurements.

\subsubsection{Optical microscopy}

The quinoa protein isolates (QPI) unheated and heated $\left(60,90\right.$ and $120{ }^{\circ} \mathrm{C}$ for $\left.30 \mathrm{~min}\right)$ were studied using optical light microscopy (Axio Scope A1, Carl Zeiss Microscopy GmbH, G€ottingen, Germany). The images were captured by the connected video camera (Axio Cam MRc5, Carl Zeiss Meditec) and acquisition software Zeiss AxioVision Rel 4.8. Images were obtained with a $40 x$ objective.

\subsubsection{Statistical analysis}

Significance testing was performed using Fisher's least significant difference (LSD) test and the differences were taken to be statistically significant when the $p$ value was $<0.05$. The multiple range test (MRT) included in the statistical programme was used to prove the existence of homogeneous groups within each of the parameters analysed. All analyses were performed using Statgraphics Centurion XVI Statistical Software (Statistical Graphics Corp., Herdon, VA).

\subsection{Results and discussion}

\subsubsection{Dry fractionation method}


Dry fractionation by milling and subsequent sieving appears to be a good alternative to wet fractionation for most grains and especially for quinoa. The milling process must be controlled to obtain the parts of interest. Of these, the embryo that consists of the radicle and two cotyledons (Figure 2.1) is the part of the seed which is richest in protein. The embryo contains $23.5 \%$ protein, while the bran and the perisperm contain only 6.1 and $7.2 \%$, respectively (Ando et al. 2002).

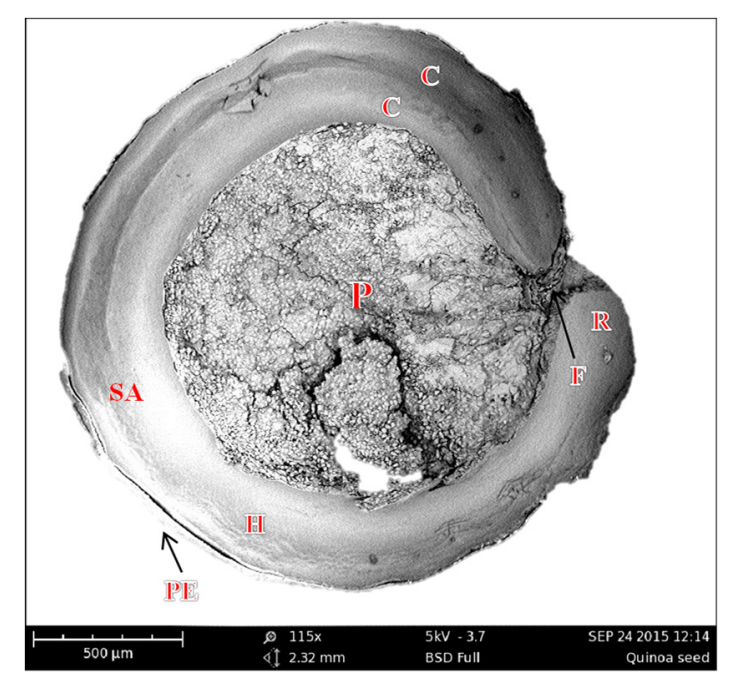

Figure 2.1. SEM image of medial longitudinal section of quinoa seed. Perisperm $(\mathrm{P})$, hypocotyl-radical axis $(\mathrm{H})$, shoot appendix (SA), cotyledons $(\mathrm{C})$, radicle $(\mathrm{R})$, funicle $(\mathrm{F})$ and pericarp $(\mathrm{PE})$.

The results of the air jet sieving experiments are presented in Table 2.1. The coarse material (> $1 \mathrm{~mm}$ ) has a low protein content. The protein content of the coarse fraction is slightly dependent on the sieve used during the milling $(1.5$ or $2.0 \mathrm{~mm})$. The richer protein fraction was obtained between the sieves $0.315-0.5 \mathrm{~mm}$ and reached $27.8 \%(\mathrm{w} / \mathrm{dw})$, which is almost three times higher than the protein content of the whole quinoa seed $(11.5 \% \mathrm{w} / \mathrm{dw})$. The protein yield of this fraction was around $45 \%$. This is higher compared to the literature values for wet fractionation (Avila et al., 2016b) and can be explained with the help of SEM images (Figure 2.2), where the different quinoa fractions are shown. The coarse fraction mainly consists of the body of the quinoa seed (perisperm), which contains mostly starch (around 82\%) and only low amounts of protein (Lindeboom, 2005). The $0.315-0.5 \mathrm{~mm}$ fraction contains high amounts of the radicle/cotyledons, which is in agreement with the high protein content. 
Table 2.1. Experimental characterization of quinoa fractions after sieving.

\begin{tabular}{lcccccc}
\hline \multirow{2}{*}{$\begin{array}{c}\text { Sieve } \\
(\mathrm{mm})\end{array}$} & \multicolumn{3}{c}{ Pre-milled (sieve 1.5 mm) } & \multicolumn{3}{c}{ Pre-milled (sieve 2.0 mm) } \\
\cline { 2 - 7 } & $\begin{array}{c}\text { Protein } \\
\text { content } \\
(\mathrm{w} / \mathrm{dw})\end{array}$ & Yield & $\begin{array}{c}\text { Protein } \\
\text { yield } \\
\end{array}$ & $\begin{array}{c}\text { Protein } \\
\text { content } \\
(\mathrm{w} / \mathrm{dw})\end{array}$ & $\begin{array}{c}\text { Yield } \\
(\%)\end{array}$ & $\begin{array}{c}\text { Protein } \\
\text { yield } \\
(\%)\end{array}$ \\
\hline$>1$ & $4.7 \pm 1.3$ & $19.5 \pm 1.3$ & $7.9 \pm 0.6$ & $3.8 \pm 0.7$ & $37.8 \pm 0.7$ & $12.1 \pm 0.3$ \\
$1-0.85$ & $3.2 \pm 0.0$ & $10.4 \pm 0.0$ & $2.9 \pm 0.0$ & $3.5 \pm 0.6$ & $8.4 \pm 0.5$ & $2.5 \pm 0.1$ \\
$0.85-0.63$ & $7.5 \pm 0.1$ & $14.3 \pm 0.4$ & $9.2 \pm 0.4$ & $7.8 \pm 0.6$ & $10.9 \pm 0.4$ & $7.1 \pm 0.2$ \\
$0.63-0.5$ & $19.3 \pm 0.3$ & $11.2 \pm 0.9$ & $18.6 \pm 1.3$ & $22.4 \pm 1.7$ & $13.1 \pm 0.9$ & $24.6 \pm 1.5$ \\
$0.5-0.315$ & $23.3 \pm 0.6$ & $23.3 \pm 0.1$ & $46.8 \pm 0.5$ & $27.8 \pm 0.0$ & $19.1 \pm 0.1$ & $44.7 \pm 0.3$ \\
$<0.315$ & $7.9 \pm 0.1$ & $21.3 \pm 0.7$ & $14.5 \pm 0.3$ & $10 \pm 0.2$ & $10.7 \pm 1.2$ & $9.0 \pm 1.1$ \\
\hline
\end{tabular}

Values are expressed as mean \pm standard deviation of three replicates.

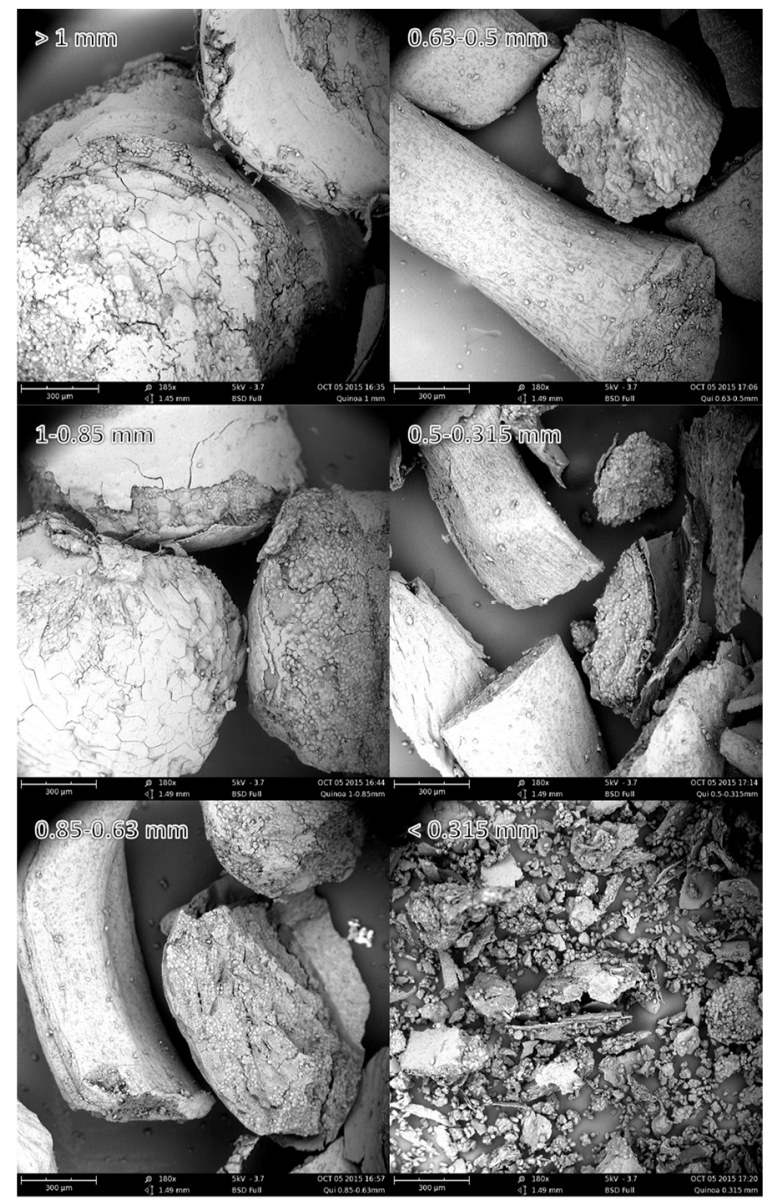

Figure 2.2. SEM images of quinoa fractions obtained by air jet sieve.

The protein content obtained is higher than was reported by previous studies (Becker \& Hanners, 1990; Ando et al., 2002; Avila et al., 2016c). Differences in protein content are related to the yield, where increased protein purity is usually reflected in lower yield. Föste et al. (2015) obtained similar results after sieving and subsequent purification of quinoa bran (31.3\%), however, they were purified using water and chemicals. There is no evidence in our fractions of damage to the perisperm after pre-milling and subsequent sieving; thus, the high-starch 
fraction will also remain a high value.

\subsubsection{Hydrolysis of quinoa protein solutions}

\subsubsection{In vitro gastric digestion of quinoa protein isolate (QPI)}

QPI with a protein content of $87.1 \%$ (w/dw) was used during digestion experiments. The yield of this method was around 54\%. The in vitro gastric digestion of QPI that was obtained via wet fractionation was measured on time and is shown in Figure 2.3. Before digestion, QPI was pretreated at various temperatures. The degree of hydrolysis (DH) increased rapidly in the first 20 min of digestion by pepsin, and then increased steadily from 20 to $360 \mathrm{~min}$. The unheated samples and samples heated at $60{ }^{\circ} \mathrm{C}$ yielded significantly higher $\mathrm{DH}$ values $(\mathrm{p}<0.05)$ at $20 \mathrm{~min}$ of digestion as compared to samples pre-treated at 90 and $120^{\circ} \mathrm{C}$, while above $20 \mathrm{~min}$ of digestion, the rates of digestion are basically similar. After $360 \mathrm{~min}$, only the samples heated at $120^{\circ} \mathrm{C}$ exhibited significantly lower digestibility $(\mathrm{p}<0.05)$. These $\mathrm{DH}$ values are slightly lower compared to the previous study by Avila et al. (2016a) using the same conditions. The reason may be the variety used in the previous study. In fact, a sweet variety (saponins free) was used, while in our study a bitter variety was used (with saponins). Avila et al. (2016b) indicated that the absence of saponins increases the solubility of proteins, so this factor could increase protein digestibility.

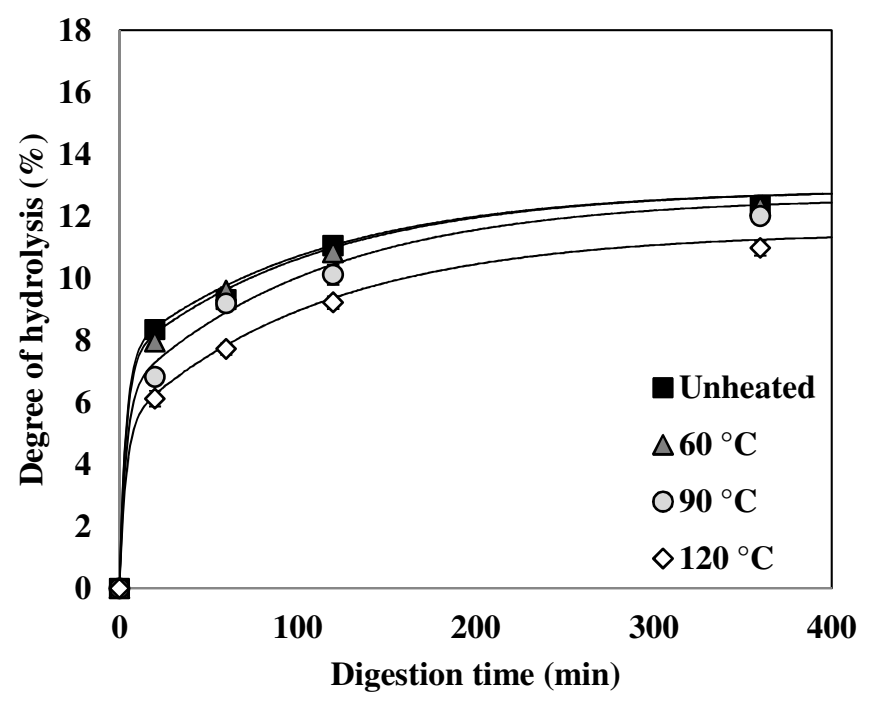

Figure 2.3. Degree of hydrolysis (DH) of QPI obtained by the wet fractionation process unheated and pre-heated at 60,90 and $120^{\circ} \mathrm{C}$.

The final amount of hydrolysed peptide bonds produced during in vitro gastric digestion is higher for a native protein solution compared to denatured protein solutions. These results are 
in line with the hypothesis that heating protein above the denaturation temperature $\left(98.1{ }^{\circ} \mathrm{C}\right)$ (Abugoch et al., 2008) leads to the formation of protein aggregates which become less accessible for pepsin to hydrolyse (Figure 2.4). The fact that heating to $120^{\circ} \mathrm{C}$ results in slower overall digestion suggests that the aggregation here leads to poorer accessibility due to stronger aggregation. This may imply a different localisation of amino acid residues that are specific to pepsin action in the quinoa protein after heating.

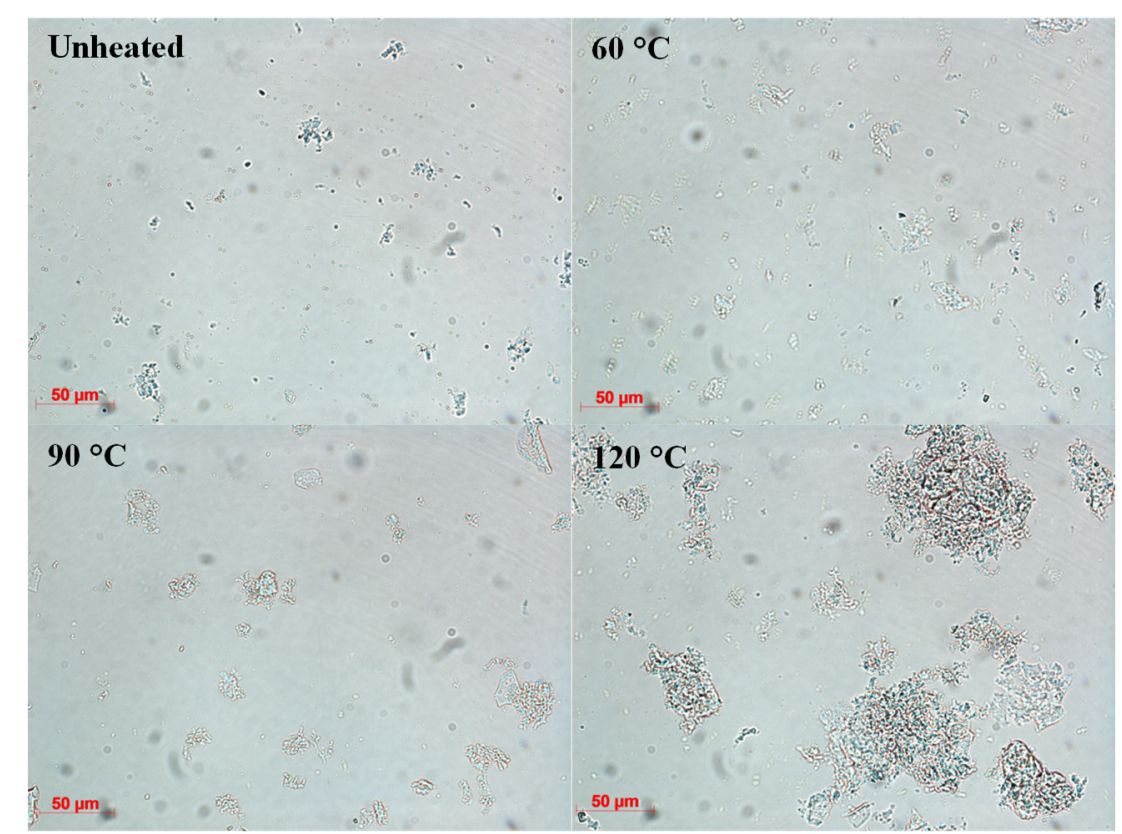

Figure 2.4. Light microscopy images of QPI solutions obtained by wet fractionation unheated and pre-heated at 60,90 and $120{ }^{\circ} \mathrm{C}$.

To evaluate the protein aggregation, particle size distribution of the suspensions before digestion was carried out (Figure 2.5). The particle size distributions showed that the QPI heated at 60 and $90{ }^{\circ} \mathrm{C}$ did not show any difference with the unheated protein, the QPI heated at 120 ${ }^{\circ} \mathrm{C}$ showed much larger aggregates, which was supported by microscopy. The samples heated at $120{ }^{\circ} \mathrm{C}$ after $30 \mathrm{~min}$ also had a gel-like substance. A similar effect was observed for spaghetti made from durum wheat, where protein aggregation due to intensive heat treatment reduced protein digestibility (Stuknyte et al., 2014). 


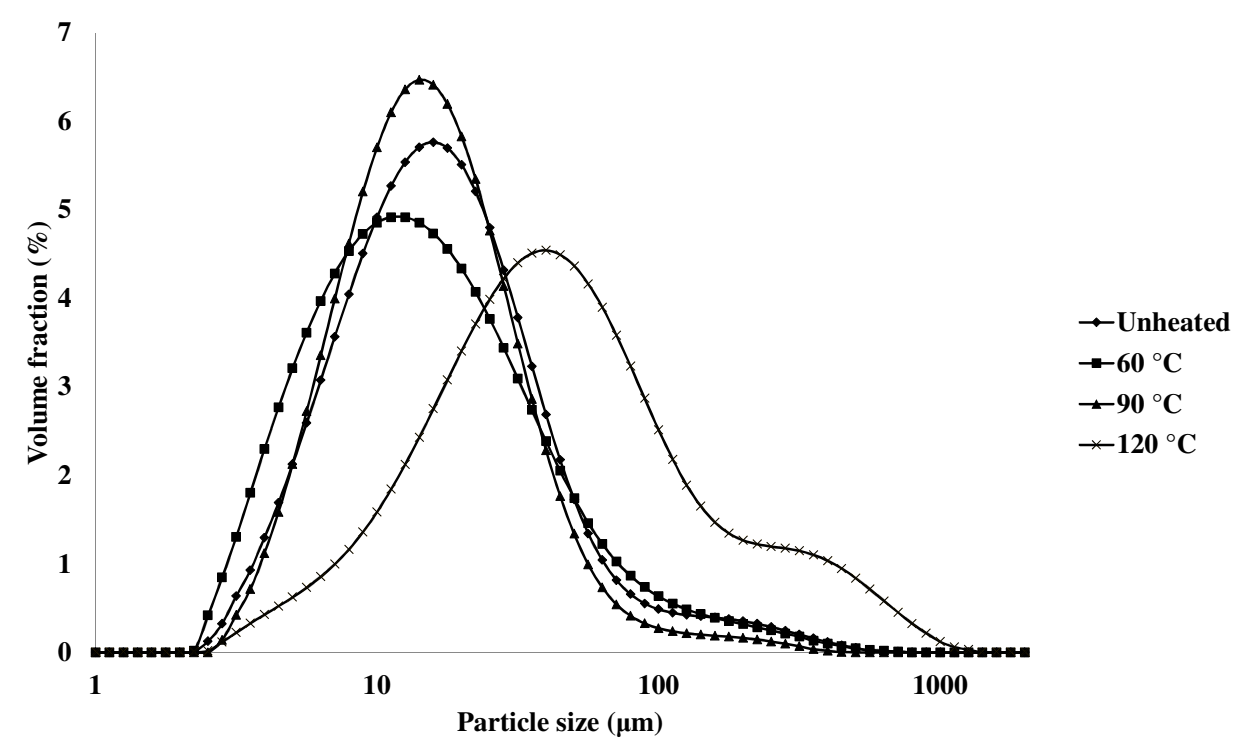

Figure 2.5. Particle size distribution of QPI unheated and pre-heated at 60,90 and $120{ }^{\circ} \mathrm{C}$ and dissolved in Milli$\mathrm{Q}$ water at $\mathrm{pH}$ 2. Curves represent the average of three independent measurements.

The differences in protein digestion between heated and unheated samples are similar to previous observations for casein digestion. In pre-heated casein, the formation of protein aggregates and thus curd-like structure in simulated gastric juice slows down the protein digestibility (Lambers et al., 2013). Some authors ascribe the decreased digestibility to the reduced solubility of the native protein after denaturation.

Carbonaro et al. (1997) indicated that heating is responsible for protein denaturation, possibly followed by aggregation of the unfolded molecules, which results in reduced solubility. This effect was also observed for meat proteins, where protein aggregation during heating was linked to the increase in surface hydrophobicity which resulted in protein insolubility (Bax et al., 2012).

The effect of temperature on plant proteins has not been studied extensively. Lupine protein concentrate unheated and heated at $60^{\circ} \mathrm{C}$ showed a higher amount of peptides formed after 30 min of gastric digestion than samples heated at $90{ }^{\circ} \mathrm{C}$ (Pelgrom et al., 2014). Soy protein isolate (SPI) heated at $100{ }^{\circ} \mathrm{C}$ for $20 \mathrm{~min}$ showed a lower digestibility than native SPI, while autoclaving at 110 and $127^{\circ} \mathrm{C}$ for 20 min significantly enhanced its digestibility (Sun et al., 2012).

From the different digestion stages of each sample, the size exclusion chromatograms (SEC) of the digested samples are presented in Figure 2.6. For all samples (heated and unheated), QPI showed a significant increase in the molecular range of $0.5-5 \mathrm{kDa}$. This confirmed the fact 
that when digestion progresses, pepsin cleaves more and more peptide sites, resulting in an increase of oligopeptides of widely varying sizes (Kaur \& Boland, 2013). As the digestion time increased, larger molecules are gradually converted into smaller peptides. After $2 \mathrm{~h}$ of pepsin proteolysis, the increase of peptides between 0.5 and $5 \mathrm{kDa}$ slows down.

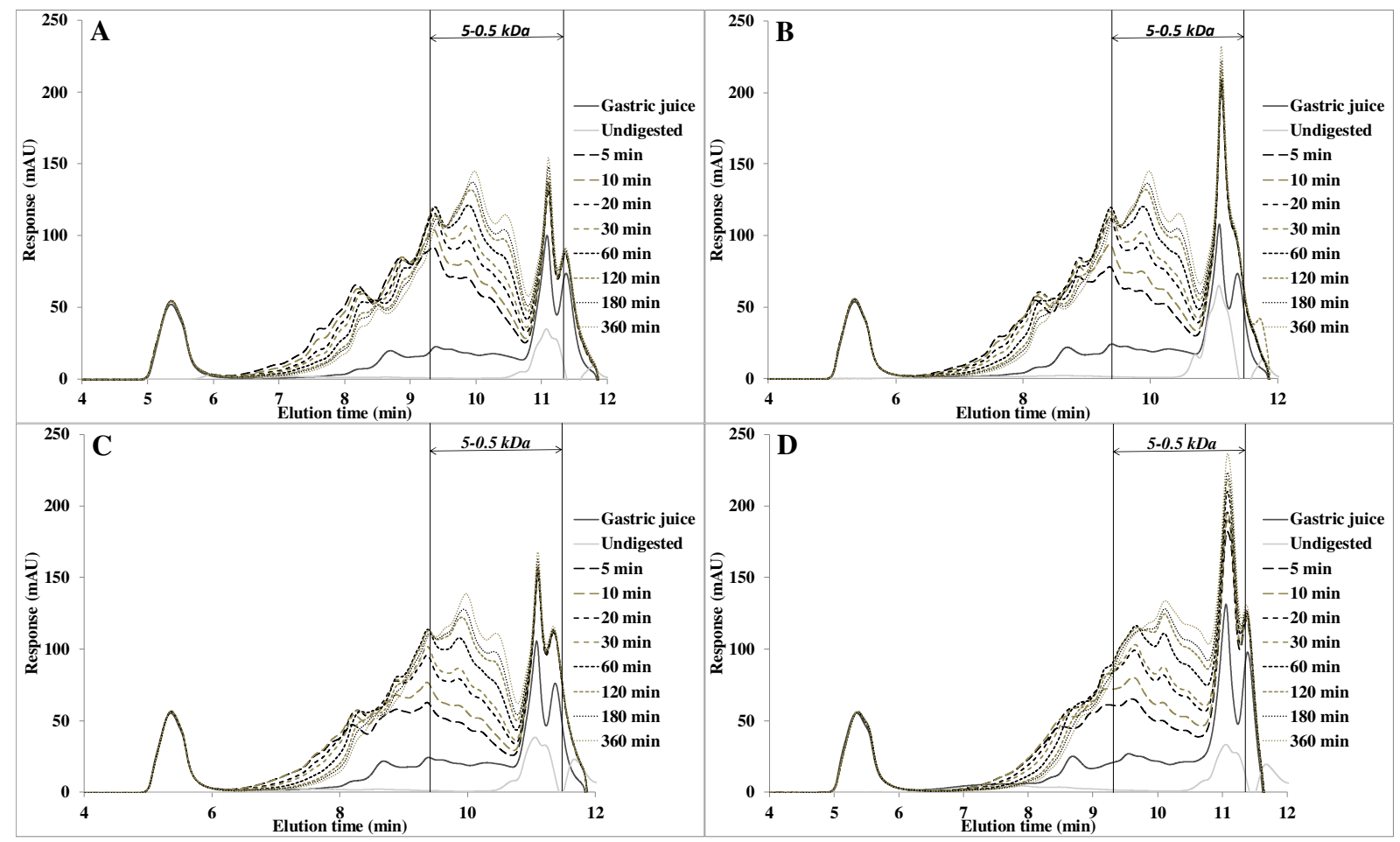

Figure 2.6. SEC-HPLC profiles of gastric digestion of QPI digested by pepsin for $6 \mathrm{~h}$ at $37^{\circ} \mathrm{C}$. (A) Unheated samples, (B) pre-heated at $60{ }^{\circ} \mathrm{C},(\mathrm{C})$ pre-heated at $90{ }^{\circ} \mathrm{C}$ and (D) pre-heated at $120{ }^{\circ} \mathrm{C}$.

The size exclusion chromatograms show only minor differences between the proteins heated to different temperatures. The main difference is that from the QPI heated to $120{ }^{\circ} \mathrm{C}$, less larger peptides (elution time between 6 and $9 \mathrm{~min}$ ) are produced, and more smaller peptides (elution time around $11 \mathrm{~min}$ ); this is indicative of the poorer accessibility of the aggregated protein for hydrolysis.

\subsubsection{In vitro gastric digestion of quinoa protein concentrate (QPC)}

While QPI obtained by means of wet fractionation is relatively pure, it has been dissolved and dehydrated by freeze drying, and its properties may have been changed by this. Dry fractionation leaves the protein in its original state, however the concentrate obtained is less pure. To determine the digestibility of quinoa protein obtained by dry fractionation, the protein fraction with a particle size of $0.315-0.5 \mathrm{~mm}$ obtained via air jet sieving was used. This quinoa protein concentrate (QPC) has a protein content of $27.8 \%(\mathrm{w} / \mathrm{dw})$ (compare with the $87.1 \%$ for 
the wet fractionated QPI). The in vitro gastric digestion of this protein-rich concentrate, dispersed in water and pre-treated at various temperatures, was followed in time (Figure 2.7). This QPC, whether heated or unheated, is digested more quickly than the QPI. This may be explained by the fact that the protein is more available for pepsin after dry fractionation. The samples heated at $60{ }^{\circ} \mathrm{C}$ do not present significant differences $(\mathrm{p}<0.05)$ in their digestibility during $6 \mathrm{~h}$ of gastric digestion process as compared to the unheated samples. However, the samples heated at 90 and $120^{\circ} \mathrm{C}$ presented a significantly lower digestibility $(\mathrm{p}<0.05)$ compared with the others during $6 \mathrm{~h}$ of digestion by pepsin.

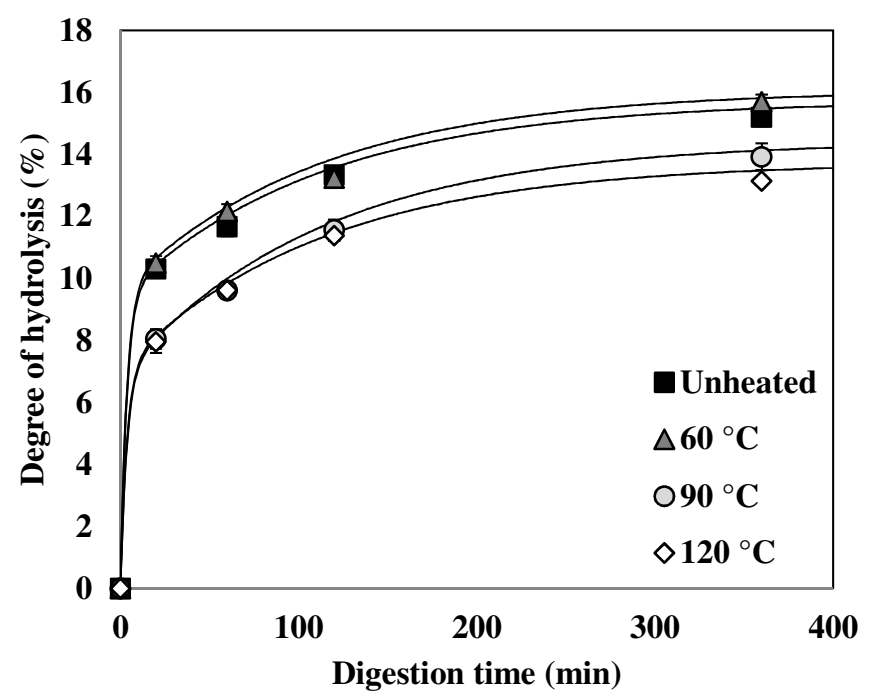

Figure 2.7. Degree of hydrolysis (DH) of quinoa protein obtained by the dry fractionation process unheated and pre-heated at 60,90 and $120^{\circ} \mathrm{C}$.

These results are opposite to those obtained with unfractionated quinoa flour heated at $91{ }^{\circ} \mathrm{C}$ for $30 \mathrm{~min}$ and autoclaved for 10 and $30 \mathrm{~min}$, because the protein digestibility increased significantly as compared with unheated quinoa flour (Ruales \& Nair, 1994). Likewise, Rathod $\&$ Annapure (2016) found that lentil protein was digested more quickly after heat treatment at $140{ }^{\circ} \mathrm{C}$. However, sorghum heated for $20 \mathrm{~min}$ in boiling water increased the amount of molecular aggregates, and reduced protein digestibility (Nunes et al., 2004).

The chromatograms of the digested QPC are presented in Figure 2.8. For all samples (heated and unheated), the chromatograms show an increase in the molecular range of $0.5-5 \mathrm{kDa}$. A comparison of the chromatograms (obtained by dry and wet fractionation) shows that in general QPI releases more small peptides than QPC. This, in combination with the faster hydrolysis of the QPC, increases the number of very small aggregates with a large specific surface area, but which do not allow access to cleave off big peptides. 


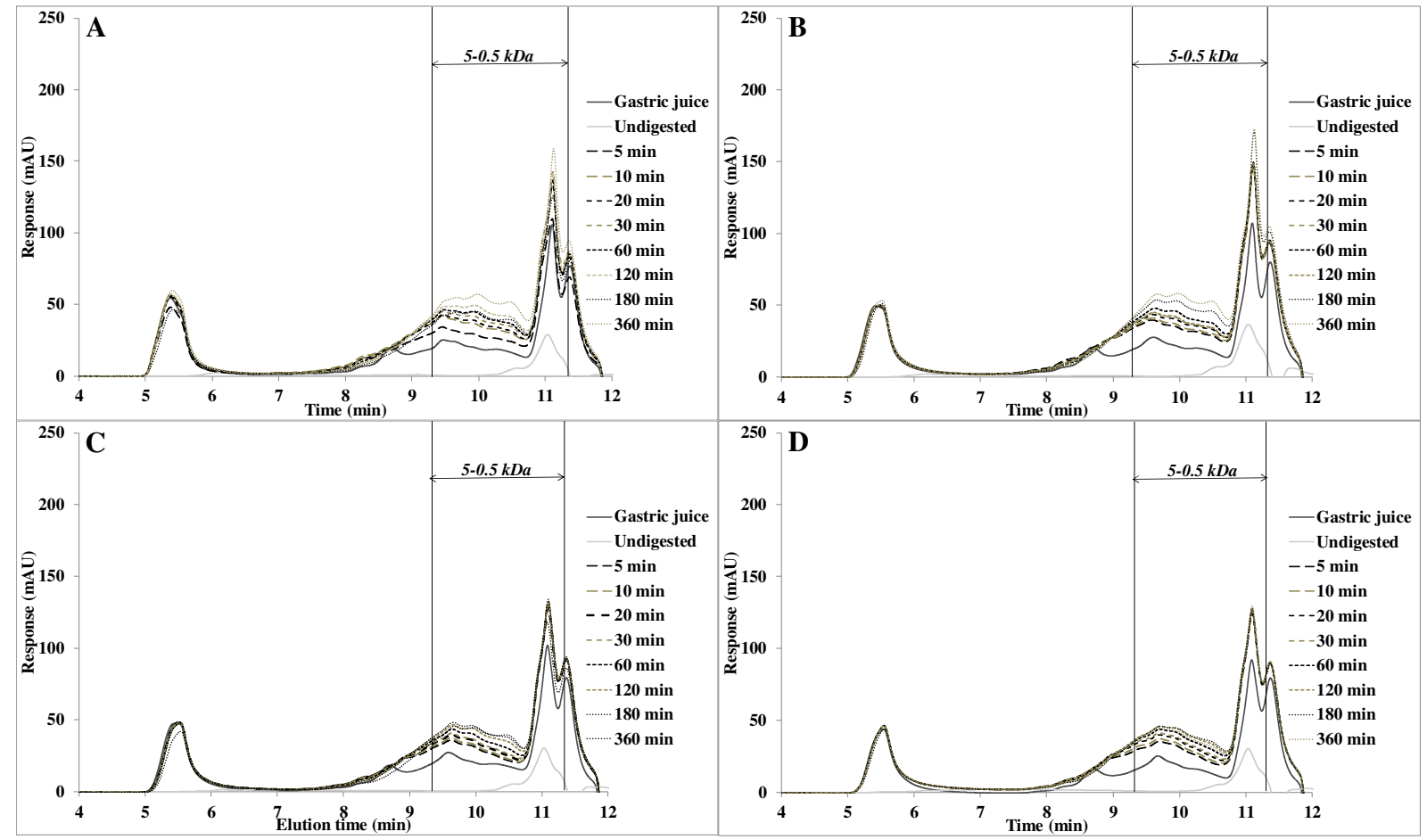

Figure 2.8. SEC-HPLC profiles of gastric digestion of DF fraction digested by pepsin for $6 \mathrm{~h}$ at $37{ }^{\circ} \mathrm{C}$. (A) Unheated samples, (B) pre-heated at $60{ }^{\circ} \mathrm{C},(\mathrm{C})$ pre-heated at $90{ }^{\circ} \mathrm{C}$ and (D) pre-heated at $120{ }^{\circ} \mathrm{C}$.

\subsubsection{Double exponential model}

We can interpret the results in Figures 2.3 and 2.7 with a simple model, in which we assume that the protein consists of a part that is easily hydrolysed (e.g. the relatively exposed residues), one part that is hydrolysed with more difficulty and one part that is not hydrolysed at all. This is represented in a simple double- exponential model according to Equation 2.3:

$D H=\alpha_{1}\left(1-e^{-k_{1} t}\right)+\alpha_{2}\left(1-e^{-k_{2} t}\right)$

In which $\alpha_{1}$ is the fraction that is most easily digested, $\alpha_{2}$ the fraction that is hydrolysed with more difficulty, and $k_{1}$ and $k_{2}$ are the hydrolysis rate constants. Fitting the results with this model, assuming that $k_{1}$ and $k_{2}$ are the same for all temperatures, we obtain Figure 2.9. While a pre-treatment below $60{ }^{\circ} \mathrm{C}$ does not have much effect on the digestion, with a pre-treatment above this temperature the quickly digestible fraction is reduced, and the slowly digestible and the undigested fraction increases above $60{ }^{\circ} \mathrm{C}$. 

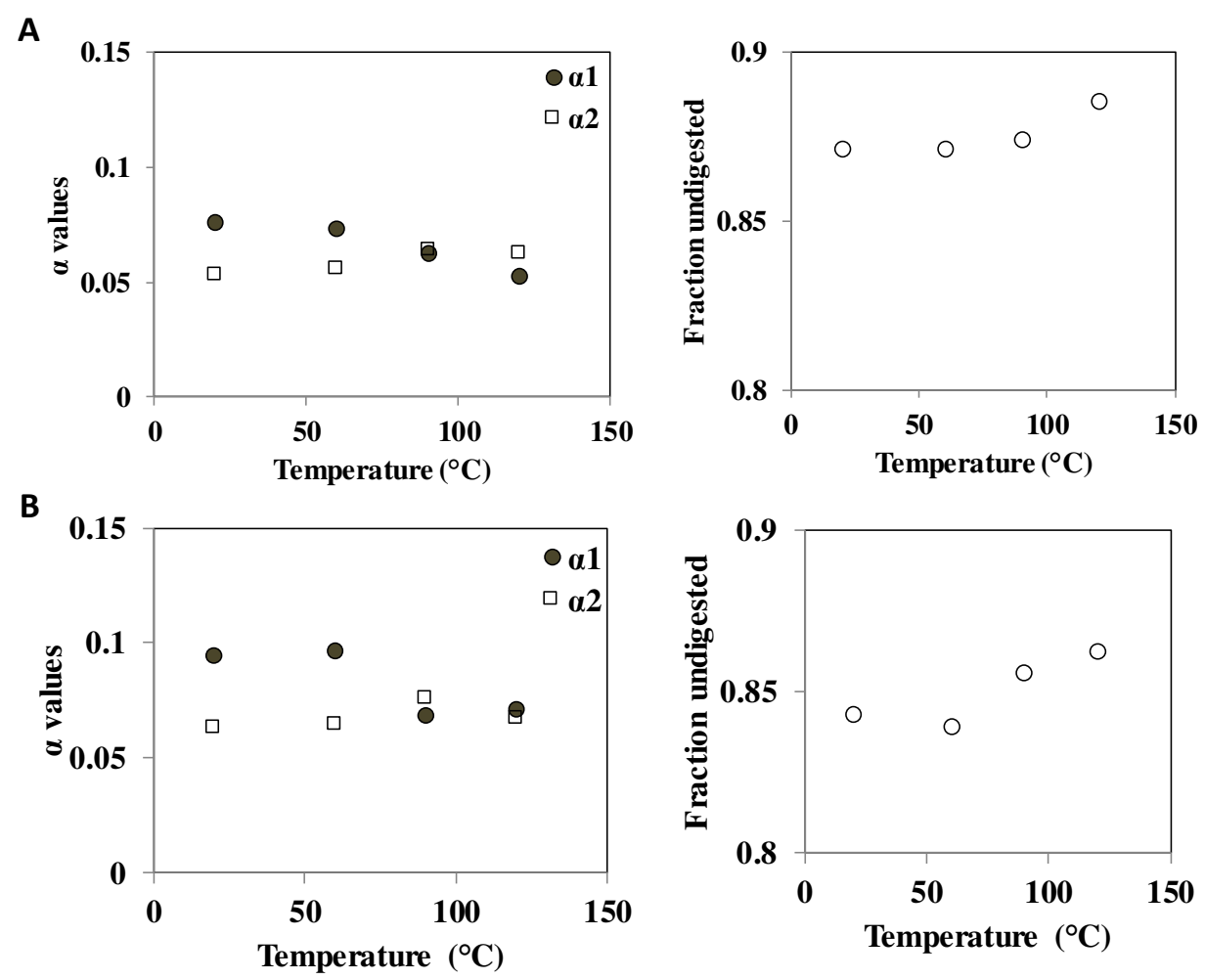

Figure 2.9. Digested fractions (left hand figure) and undigested fraction (right hand figure), as function of the pretreatment temperature. The rate constants were assumed to be the same for QPI and QPC, and were fitted at $\mathrm{k} 1=0.280 \mathrm{~min}-1$, and $\mathrm{k} 2=0.00895 \mathrm{~min}-1$. (A) Wet fractionated QPI and (B) dry fractionated QPC.

We see that the wet fractionated QPI (Figure 2.9A) and the dry fractionated QPC (Figure 2.9B) both show similar behaviour: both show an increase of the indigestible fraction, and a decrease of the rapidly digestible fraction, when the protein is pre-heated above $60{ }^{\circ} \mathrm{C}$. The non-digested fraction of the QPC is lower than that of the QPI, while the slowly digested fraction is only slightly higher. Overall, QPC is better digestible. In the fits, the values for the rate constants were assumed to be the same for QPI and QPC. This can, of course, be disputed; the precise value of at least $k_{1}$ was found to barely influence the quality of the fit; the values for $k_{2}$ are more important, however, fitting separate values for QPI and QPC gives almost the same value.

One can observe that pre-heating the QPC to temperatures higher than $60{ }^{\circ} \mathrm{C}$, leads to a sudden loss in rapidly digestible protein. Even though the digestibility of the QPI also decreases at higher temperatures, this drop is more gradual. We hypothesise that this is because of the presence of starch in the QPC, which will reduce the accessibility of the protein for pepsin.

\subsubsection{Effect of starch on digestibility of quinoa protein}

To asses this hypothesis, we added starch to QPI, and heated solutions to 90 and $120^{\circ} \mathrm{C}$. Figure 
2.10 shows the digestibility, compared to QPI, that was pre-heated at 90 and $120{ }^{\circ} \mathrm{C}$ (compare Figure 2.3). Indeed, an increase in the starch concentration results in a significantly lower $(\mathrm{p}<0.05)$ protein digestibility. In fact, with QPI heated at $90{ }^{\circ} \mathrm{C}$ the lower digestibility does not seem to depend on the starch concentration, while at $120{ }^{\circ} \mathrm{C}$ a dependency on the starch concentration is shown. The DH after $6 \mathrm{~h}$ of digestion by pepsin was $11.5 \pm 0.2 \%$ for heated samples at $120{ }^{\circ} \mathrm{C}$, while these were $9.4 \pm 0.1 \%$ and $8.4 \pm 0.2 \%$ for the samples with 20 and $50 \%$ of starch, respectively. These values are significantly lower $(\mathrm{p}<0.05)$ than those obtained by digestion of dry fractionated samples subjected to the same treatment (Figure 2.4). This result shows that starch has an effect on protein digestibility. Wong et al. (2009) found that when starch was removed by $\alpha$-amylase from sorghum flour, the protein digestibility by pepsin became considerably higher. When starch is removed, the quinoa proteins are more exposed and thus more accessible to pepsin digestion. Furthermore, the increase in viscosity reduces the diffusivity of both the enzyme and the protein. The quinoa starch yields a high final viscosity 5.67 $\mathrm{Pa} \mathrm{s}$ (measured in this work) in comparison with rice (4.47 $\mathrm{Pa} \mathrm{s}$ ), potato (3.89 $\mathrm{Pa} \mathrm{s}$ ), cassava (2.91 Pa s), wheat (2.99 Pa s) and corn (2.99 Pa s) (Araujo-Farro et al. 2005). This final viscosity is associated with retrogradation between starch molecules (particularly amylose component) and in sufficient concentration causes the formation of a gel.

A

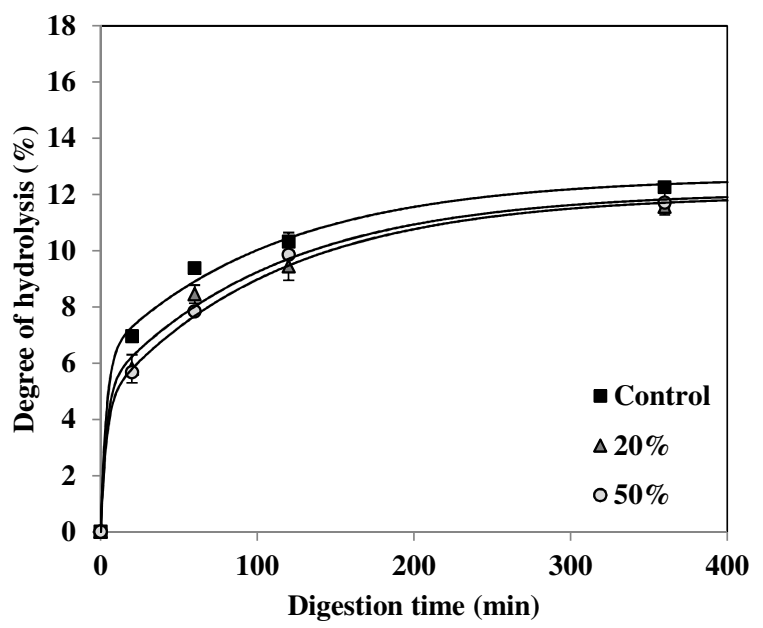

B

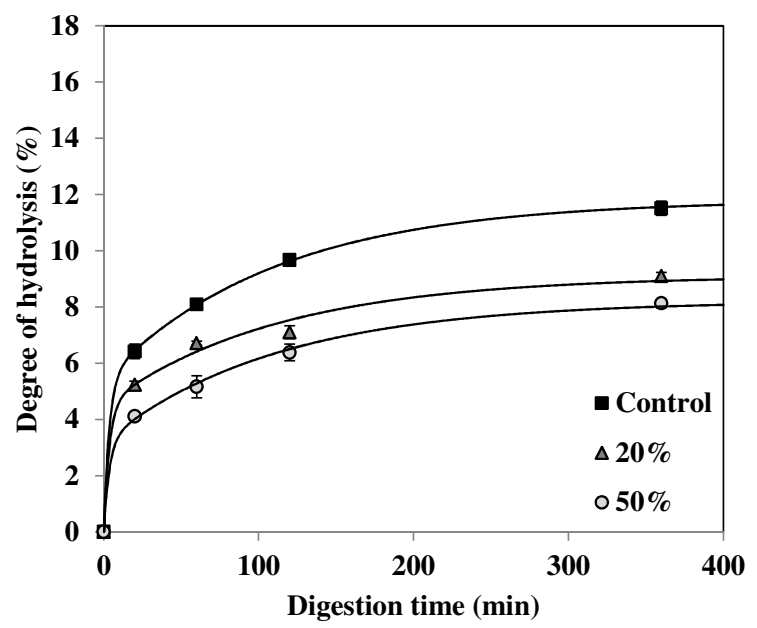

Figure 2.10. Degree of hydrolysis (DH) of the mixture of 5\% of QPI and starch added at different concentrations $\left(0,20\right.$ and $50 \%$ of starch) and pre-heated at (A) $90{ }^{\circ} \mathrm{C}$ and (B) $120{ }^{\circ} \mathrm{C}$ for $30 \mathrm{~min}$.

Our finding that QPC is better digestible than the QPI can therefore not be ascribed to the presence of starch and possibly other components, but must be attributed to the condition of the protein itself. In our experiments, starch was added only after isolation of the quinoa protein. It 
may be then that the protein is already aggregated into larger aggregates, making the protein relatively inaccessible to pepsin. In the case of QPC, the protein was kept in its natural state, i.e. in the form of protein bodies surrounded by some matrix components, such as carbohydrates and starch. These matrix components may inhibit the formation of larger aggregates when the protein is denatured and lead to smaller aggregates that are better accessible for pepsin.

\subsection{Conclusions}

In conclusion, the method proposed in the present study can provide a protein concentrate with a protein purity of $28 \%(\mathrm{w} / \mathrm{dw})$ and a protein yield of $45 \%$. QPI showed slower digestibility than QPC with all preheating temperatures, even though all fractions showed reduced digestibility when preheated to higher temperatures. QPC showed reduced digestibility above $60{ }^{\circ} \mathrm{C}$. This could be explained by the presence of starch, which after being heated above its gelatinisation temperature $\left(64.5^{\circ} \mathrm{C}\right)$ increases the viscosity and reduces the accessibility of the protein for pepsin. The better digestibility of the dry fractionated QPC was found not to be linked to the carbohydrates present in this fraction, but may be due to the prevention of the formation of large aggregates during pre-heating of the protein.

\subsection{References}

Abugoch, L.E., Romero, N., Tapia, C.A., Silva, J., \& Rivera, M. (2008). Study of some physicochemical and functional properties of quinoa (Chenopodium quinoa Willd) protein isolates. Journal of Agricultural and Food Chemistry, 56, 4745-4750.

Adler-Nielsen, J. (1986). Enzymic hydrolysis of food proteins. New York: Elsevier Applied Science Publishers. pp. 110-169.

Ando, H., Chen, Y.-C., Tang, H., Shimizu, M., Watanabe, K., \& Mitsunaga, T. (2002). Food components in fractions of quinoa seed. Food Science and Technology Research, 8, 8084.

Araujo-Farro, P.C., Amaral, J.P., \& Menegalli, F.C. (2005). Comparison of starch pasting and retrogradation properties of Quinoa (Chenopodium quinoa Willd), rice, potato, cassava, wheat and corn starches. Presented at 2nd Mercosur Congress on Chemical Engineering; Rio de Janeiro, Brazil.

Avila, R.G., Opazo-Navarrete, M., Meurs, M., Minor, M., Sala, G., van Boekel, M., \& Janssen, 
A.E.M. (2016a). Denaturation and in vitro gastric digestion of heat-treated quinoa protein isolates obtained at various extraction pH. Food Biophysics. 11, 184-197.

Avila, R.G., Xiao, W., van Boekel, M., Minor, M., \& Stieger, M. (2016b). Effect of extraction $\mathrm{pH}$ on heat induced, gelation and microstructure of protein isolate from quinoa (Chenopodium quinoa Willd). Food Chemistry, 209, 203-210.

Avila, R.G., Arts, A., Minor, M., \& Schutyser, M.A.I. (2016c). A hybrid dry and aqueous fractionation method to obtain protein-rich fractions from Quinoa (Chenopodium quinoa Willd). Food and Bioprocess Technology, 9, 1502-1510.

Bax, M.L., Aubry, L., Ferreira, C., Daudin, J.D., Gatellier, P., Rémond, D., \& Santé-Lhoutellier, V. (2012). Cooking temperature is a key determinant of in vitro meat protein digestion rate: investigation of underlying mechanisms. Journal of Agricultural and Food Chemistry, 60, 2569-2576.

Becker, R., \& Hanners, G.D. (1990). Compositional and nutritional evaluation of quinoa whole grain flour and mill fractions. LWT-Food Science and Technology, 23, 441-444.

Carbonaro, M., Cappelloni, M., Nicoli, S., Lucarini, M., \& Carnovale, E. (1997). Solubilitydigestibility relationship of legume proteins. Journal of Agricultural and Food Chemistry, 45, 3387-3394.

Casey, B.E., \& Laidler, K.J. (1951). The kinetics and mechanism of the heat inactivation of pepsin. Journal of the American Chemical Society, 73, 1455-1457.

FAO/WHO/UNU. (2007). Report of a Joint FAO/WHO/UNU Expert Consultation; Protein and Amino Acid Requirements in Human Nutrition. WHO Technical Report Series; Geneva, Switzerland.

Föste, M., Elgeti, D., Brunner, A.-K., Jekle, M., \& Becker, T. (2015). Isolation of quinoa protein by milling fractionation and solvent extraction. Food and Bioproducts Processing, 96, 20-26.

Guillaume, J., Kaushik, S., Bergot, P., \& Metailler, R. (2001). Digestive physiology and nutrient digestibility in fishes. In Nutrition and Feeding of Fish and Crustaceans. Chichester, U.K: Praxis Publishing. 
He, J.-S., Mu, T.-H., \& Wang, J. (2013). A comparative in vitro study of the digestibility of heat- and high pressure-induced gels prepared from industrial milk whey proteins. High Pressure Research, 33, 328-335.

Kaur, L., \& Boland, M. (2013). Influence of kiwifruit on protein digestion. Advances in Food and Nutrition Research, 68,149-167.

Lambers, T.T., Van Den Bosch, W.G., \& De Jong, S. (2013). Fast and slow proteins: modulation of the gastric behavior of whey and casein in vitro. Food Digestion, 4, 1-6.

Lindeboom, N. (2005). Studies on the characterization, biosynthesis and isolation of starch and protein from quinoa (Chenopodium quinoa Willd). Department of Applied Microbiology and Food Science University of Saskatchewan; Saskatoon, Canada (PhD Thesis).

Luo, Q., Boom, R.M., \& Janssen, A.E.M. (2015). Digestion of protein and protein gels in simulated gastric environment. LWT - Food Science and Technology, 63, 161-168.

Martínez, E.A., Veas, E., Jorquera, C., San Martín, R., \& Jara, P. (2009). Re-introduction of Quinoa into arid Chile: cultivation of two lowland races under extremely low irrigation. Journal of Agronomy and Crop Science, 195, 1-10.

Nascimento, A.C., Mota, C., Coelho, I., Gueifão, S., Santos, M., Matos, A.S., Gimenez, A., Lobo. M, Samman, N., \& Castanheira, I. (2014). Characterisation of nutrient profile of quinoa (Chenopodium quinoa), amaranth (Amaranthus caudatus), and purple corn (Zea mays L.) consumed in the North of Argentina: proximates, minerals and trace elements. Food Chemistry, 148, 420-426.

Nielsen, P.M., Petersen, D., \& Dambmann, C. (2001). An improved method for determining food protein degree of hydrolysis. Journal of Food Science, 66, 642-646.

Nunes, A., Correia, I., Barros, A., \& Delgadillo, I. (2004). Sequential in vitro pepsin digestion of uncooked and cooked sorghum and maize samples. Journal of Agricultural and Food Chemistry, 52, 2052-2058.

Pelgrom, P.J.M., Berghout, J.A.M., van der Goot, A.J., Boom, R.M., \& Schutyser, M.A.I. (2014). Preparation of functional lupine protein fractions by dry separation. LWT - Food 
Science and Technology, 59, 680-688.

Rathod, R.P., \& Annapure, U.S. (2016). Effect of extrusion process on antinutritional factors and protein and starch digestibility of lentil splits. LWT - Food Science and Technology, $66,114-123$.

Ruales, J., \& Nair, B.M. (1994). Effect of processing on in vitro digestibility of protein and starch in quinoa seeds. International Journal of Food Science \& Technology, 29, 449456.

Ruales, J., \& Nair, B.M. (1992). Nutritional quality of the protein in quinoa (Chenopodium quinoa Willd) seeds. Plant Foods for Human Nutrition, 42, 1-11.

Schutyser, M.A.I., \& van der Goot, A.J. (2011). The potential of dry fractionation processes for sustainable plant protein production. Trends in Food Science \& Technology, 22, 154 164.

Sun, M., Mu, T., Zhang, M., \& Arogundade, L.A. (2012). Nutritional assessment and effects of heat processing on digestibility of Chinese sweet potato protein. Journal of Food Composition and Analysis, 26, 104-110.

Stuknyte, M., Cattaneo, S., Pagani, M.A., Marti, A., Micard, V., Hogenboom, J., \& De Noni, I. (2014). Spaghetti from durum wheat: effect of drying conditions on heat damage, ultrastructure and in vitro digestibility. Food Chemistry, 149, 40-46.

Tang, Y., Li, X., Zhang, B., Chen, P.X., Liu, R., \& Tsao, R. (2015). Characterisation of phenolics, betanins and antioxidant activities in seeds of three Chenopodium quinoa Willd. genotypes. Food Chemistry, 166, 380-388.

Whitney, E.N., Cataldo, B.C., \& Sharon, R.R. (1998). Understanding normal and clinical nutrition. 5th ed. Belmont, USA: Wadsworth Publishing Company Inc.

Wong, J.H., Lau, T., Cai, N., Singh, J., Pedersen, J.F., Vensel, W.H., Hurkman, W.L., Wilson, J.D., Lemaux, P.G., \& Buchanan, B. (2009). Digestibility of protein and starch from sorghum (Sorghum bicolor) is linked to biochemical and structural features of grain endosperm. Journal of Cereal Science, 49, 73-82. 


\section{Chapter 3}

Denaturation and in vitro gastric digestion of heat-treated quinoa protein isolates obtained at various extraction $\mathrm{pH}$

The first two authors contributed equally to this work

This chapter has been published as: Avila Ruiz, G., Opazo-Navarrete, M., Meurs, M., Minor, M., Sala, G., van Boekel, M., Stieger, M., \& Janssen, A.E.M. (2016). Denaturation and in vitro gastric digestion of heat-treated quinoa protein isolates obtained at various extraction $\mathrm{pH}$. Food Biophysics, 11, 184-197. 


\subsection{Abstract}

The aim of this study was to determine the influence of heat processing on denaturation and digestibility properties of protein isolates obtained from sweet quinoa (Chenopodium quinoa Willd) at various extraction $\mathrm{pH}$ values $(8,9,10$ and 11$)$. Pre-treatment of suspensions of protein isolates at 60,90 and $120^{\circ} \mathrm{C}$ for $30 \mathrm{~min}$ led to protein denaturation and aggregation, which was enhanced at higher treatment temperatures. The in vitro gastric digestibility measured during 6 $\mathrm{h}$ was lower for protein extracts pre-treated at 90 and $120{ }^{\circ} \mathrm{C}$ compared to $60{ }^{\circ} \mathrm{C}$. The digestibility decreased with increasing extraction $\mathrm{pH}$, which could be ascribed to protein aggregation. Protein digestibility of the quinoa protein isolates was higher compared to wholemeal quinoa flour. We conclude that an interactive effect of processing temperature and extraction $\mathrm{pH}$ on in vitro gastric digestibility of quinoa protein isolates obtained at various extraction $\mathrm{pH}$ is observed. This gives a first indication of how the nutritional value of quinoa protein could be influenced by heat processing, protein extraction conditions and other grain components. 


\subsection{Introduction}

Quinoa has a balanced amino acid profile with high amounts of lysine and methionine. Sweet varieties of quinoa are more promising to provide high-quality protein in a more economic and sustainable way than the bitter quinoa varieties. More economic because saponins do not have to be removed, which saves in post-harvest processing. More sustainable because sweet varieties have been successfully adapted to North West European climates and soils, and could also be adapted to other regions in the world, making local quinoa production possible (Limburg \& Mastebroek, 1997; Mastebroek et al., 2002). Protein functionality is an important aspect to evaluate the potential of a new protein and give guidance for usage in applications. To avoid influences from other grain components in assessing the protein potential as a food ingredient, the protein can best be isolated from the grain for subsequent analysis. Conventionally, solvent extraction is used to isolate protein from plant material. During this process, protein properties and thus functionality can be affected (Avila Ruiz et al., 2016). Only a few studies have examined the impact of extraction conditions on functional properties of quinoa protein so far, and only our previous study has investigated properties of quinoa protein from sweet quinoa (saponin-free) (Aora et al., 2009; Abugoch et al., 2008; Valenzuela et al., 2008). The absence of saponins has been found to influence protein efficiency ratio, nitrogen solubility, emulsifying and foaming properties (Avila Ruiz et al., 2016). Next to extraction conditions, post-extraction processing can also influence protein properties. A few recent studies have investigated the effects of post-extraction heating on some properties of Quinoa Protein Isolates (QPI). We previously found that QPI suspensions started to gel at about $70{ }^{\circ} \mathrm{C}$ when extracted at $\mathrm{pH} 8$ and 9 but no gelation was observed when extracted at pH 10 or 11.Maekinen et al. (2015) reported that cold-set QPI gels were finer, more regularly structured and had a higher storage modulus when QPI suspensions were heat-treated $\left(100{ }^{\circ} \mathrm{C}, 15 \mathrm{~min}\right)$ at $\mathrm{pH} 10.5$ than when heat-treated at pH 8.5 (Mäkinen et al., 2015). Silva et al. (2015) found that heat treatments (100 $\left.{ }^{\circ} \mathrm{C}, 30 \mathrm{~min}\right)$ of quinoa protein fractions containing anti-nutritional factors increased in vitro protein digestibility. To the best of our knowledge, no studies have investigated the effect of varying heat processing parameters on protein denaturation and digestibility of QPIs. Protein denaturation and digestibility are main determinants of protein quality and would be important for application of quinoa (protein) in food products (Guo et al., 2007). Gastric protein digestibility is a first indicator of overall protein digestibility and nutritional value of the protein (Sarker et al., 2015; Budryn et al., 2013; Hoppe et al., 2013; Mokrane et al., 2010; Mertz et al., 1984). Therefore, in the present study, we examined how heat processing at different 
temperatures influenced denaturation properties and in vitro gastric digestibility of sweet quinoa protein isolated at various extraction $\mathrm{pH}$ values. Based on literature, we hypothesize that heat processing in the temperature range of 60 to $120{ }^{\circ} \mathrm{C}$ increases in vitro gastric digestibility of the quinoa protein at mildly alkaline extraction $\mathrm{pH}$ and decreases the digestibility at strongly alkaline extraction $\mathrm{pH}$.

\subsection{Material and methods}

\subsubsection{Materials}

Quinoa seeds (Chenopodium quinoa Willd) of the sweet variety Atlas were supplied by the Agricultural Research Institute (INIA) in Santiago, Chile. Petroleumether (boiling range 40 $60{ }^{\circ} \mathrm{C}$ ) was used (Sigma-Aldrich Chemie $\mathrm{GmbH}$, Schnelldorf, Germany). Chemicals for preparation of the simulated gastric juice were purchased from Sigma-Aldrich, Inc. (St. Louis, MO, U.S.A.).

\subsubsection{Preparation of quinoa protein isolates}

Quinoa seeds were ground with a Fritsch Mill Pulverisette 14 (Idar-Oberstein, Germany) using a speed of $7000 \mathrm{rpm}$ and sieved through a $200 \mu \mathrm{m}$ sieve. The flour was defatted in a Soxhlet using petroleum ether with a sample-to-solvent mass ratio of 1:5 for $24 \mathrm{~h}$ (Pelgrom et al., 2015). The petroleum ether was removed by evaporation. The defatted flour was suspended in deionized water (10\% w/w) and the $\mathrm{pH}$ was adjusted to $8,9,10$ and 11 by addition of $1 \mathrm{~N}$ $\mathrm{NaOH}$. The suspensions were stirred for $1 \mathrm{~h}$ at room temperature and centrifuged for $20 \mathrm{~min}$ at $6,000 \mathrm{~g}$ and $10^{\circ} \mathrm{C}$. The obtained supernatants were acidified to $\mathrm{pH} 5.5$ by addition of $1 \mathrm{~N} \mathrm{HCl}$. The suspensions were centrifuged for $30 \mathrm{~min}$ at $13,000 \mathrm{~g}$ and $10{ }^{\circ} \mathrm{C}$. The precipitated pellets were re-suspended in deionized water $(5 \% \mathrm{w} / \mathrm{w})$. To rinse remaining salts the suspensions were centrifuged for $20 \mathrm{~min}$ at $11,000 \mathrm{~g}$ and $10{ }^{\circ} \mathrm{C}$, re-suspended in deionized water (5\% w/w) and neutralized by addition of $1 \mathrm{~N} \mathrm{NaOH}$. The suspensions were frozen by dipping into liquid nitrogen and subsequently freeze-dried for 72 h (Chris Epsilon 2-6D Freeze Dryer, Osterode am Harz, Germany). The dried protein isolates were ground with a spoon for about $30 \mathrm{~s}$ to obtain powders. Isolates were obtained in duplicate from two separate extractions.

\subsubsection{Determination of protein yield and purity}

8 to $15 \mathrm{mg}$ QPI was weighed in tin cups and dried overnight at $60^{\circ} \mathrm{C}$. The nitrogen content was determined by sample combustion in a Dumas Flash EA 1112, Series NC analyzer (Wigan, 
UK) and converted to crude percentage of protein using a protein factor of 5.85 (Abugoch et al., 2008; Castellani et al., 1998; Becker et al., 1981). Measurements were performed in duplicate. Protein yield and protein purity were calculated as follows:

Protein yield $(\%)=\frac{\text { protein content isolate }(\%) \cdot \operatorname{dry} \text { isolate }(g)}{\text { protein content flour }(\%) \cdot \text { flour }(g)} \cdot 100$
Protein purity $(\%)=\frac{\text { protein content isolate }(\%) \cdot \operatorname{dry} \text { isolate }(g)}{\text { dry isolate }(g)} \cdot 100$

Equation 3.1

Equation 3.2

\subsubsection{Heat processing of quinoa protein isolates}

Suspensions of the QPIs obtained at the different extraction $\mathrm{pH}$ values were prepared at protein concentrations 1,5 and $20 \% \mathrm{w} / \mathrm{w}$ in deionized water and stirred for $1 \mathrm{~h}$ at room temperature. For the heat processed samples, the suspensions were heat-treated in an Eppendorf thermomixer (Eppendorf AG, Hamburg, Germany) for $30 \mathrm{~min}$ at 60,90 and $120{ }^{\circ} \mathrm{C}$ and then cooled down to room temperature. The temperatures were selected based on temperatures used in applications and to test within a wide range of temperatures. A temperature of $90{ }^{\circ} \mathrm{C}$ represents pasteurization conditions, while a temperature of $120{ }^{\circ} \mathrm{C}$ is representative for sterilization conditions. Treatment at $60{ }^{\circ} \mathrm{C}$ was chosen as mild heating temperature without causing denaturation of the quinoa protein. The terms "processing temperature of $20{ }^{\circ} \mathrm{C}$ " and "unprocessed" refer to the incubation of QPI suspensions at $20^{\circ} \mathrm{C}$ without further treatment.

\subsubsection{Determination of molecular weight}

Sodium dodecyl sulphate-polyacrylamide gel electrophoresis (SDS-PAGE) was used to determine the molecular weight distribution of the quinoa protein isolate fractions. Heatprocessed and unprocessed suspensions of $1 \% \mathrm{w} / \mathrm{w}$ protein concentration were prepared. The suspensions were then re-suspended in deionized water $(\mathrm{pH} 6.5 \pm 0.1)$ and centrifuged for 1 min at $13,000 \mathrm{~g}$ to obtain the solubilized protein. The supernatants were diluted with $1 \mathrm{x}$ NuPAGE ${ }^{\circledR}$ LDS Sample Buffer and deionized water before applying the samples to the gel. NuPAGE ${ }^{\circledR}$ Novex ${ }^{\circledR}$ Bis-Tris Gels $(1-200 \mathrm{kDa})$ containing $12 \%$ acrylamide $(4 \%$ acrylamide stacking gel) were used. The molecular weight markers were from NuPAGE ${ }^{\circledR}$ Novex $^{\circledR}$ (Mark $12^{\mathrm{TM}}$ Unstained Standard, $2.5-200 \mathrm{kDa}$ ). Protein bands were stained with Simply Blue $\mathrm{T}^{\mathrm{TM}}$ SafeStain.

\subsubsection{Determination of thermal properties}


The thermal properties of the QPIs were assessed by Differential Scanning Calorimetry (DSC). Heat-processed and unprocessed suspensions of $20 \% \mathrm{w} / \mathrm{w}$ protein concentration were prepared. Hermetically sealed aluminum pans were filled with $25-50 \mathrm{mg}$ of heat-processed or unprocessed QPI suspensions. DSC samples were heated at a rate of $10{ }^{\circ} \mathrm{C} / \mathrm{min}$ from 20 to 140 ${ }^{\circ} \mathrm{C}$ using a PerkinElmer Diamond series differential scanning calorimeter equipped with an intracooler 2P. A double, empty pan was used as reference. The denaturation parameters were calculated using Pyris Software (Version 11, PerkinElmer) with the denaturation temperature $\left(T_{d}\right)$ value corresponding to the maximum transition peak and the transition enthalpy (denaturation enthalpy $\Delta H$ ) calculated from the area below the transition peaks. Measurements were performed in duplicate for isolates obtained in duplicate.

\subsubsection{Determination of in vitro gastric protein digestibility}

Simulated gastric juice was prepared according to Kong \& Singh (2009) and Luo et al. (2015). Pepsin $(1 \mathrm{~g} / \mathrm{L})$, mucin $(1.5 \mathrm{~g} / \mathrm{L})$, and $\mathrm{NaCl}(8.775 \mathrm{~g} / \mathrm{L})$ were dissolved in Milli-Q water and the $\mathrm{pH}$ was adjusted to 2.0 with $2 \mathrm{M} \mathrm{HCl}$. Heat-processed and unprocessed QPI suspensions, as well as suspensions of whole meal quinoa flour (5\% w/w protein, $2 \mathrm{~mL})$, were prepared and added to $50 \mathrm{~mL}$ of simulated gastric juice in a jacketed glass vessel connected to a water bath at $37{ }^{\circ} \mathrm{C}$ (Julabo $\mathrm{GmbH}$, Seelbach, Germany). The vessel was sealed with Parafilm (Pechiney Plastic Packaging, Inc., IL, U.S.A.) to avoid evaporation and the gastric juice solutions were stirred at $100 \mathrm{rpm}$. Samples of $1 \mathrm{~mL}$ were taken after 0, 5, 10, 15, 20, 30, 45, 60, 90, 120, 150, 180, 240 and $360 \mathrm{~min}$ and heated under stirring in a pre-heated Eppendorf thermomixer (Eppendorf AG, Hamburg, Germany) at $90{ }^{\circ} \mathrm{C}$ and 1,400 rpm for $5 \mathrm{~min}$ to inactivate pepsin (Casey \& Laidler, 1951). All measurements were performed in triplicate.

\subsubsection{Determination of degree of hydrolysis (DH)}

The degree of hydrolysis (DH) is defined as the percentage of cleaved peptide bonds over the total number of peptide bonds. The latter was calculated as follows:

Total number of peptide bonds $=\frac{1000 \mathrm{~g} \text { protein }}{\text { average molecular weigth of amino acids }(k D a)} \quad$ Equation 3.3

To estimate DH, the OPA method was used as described by Luo et al. (2015). The OPA reagent was prepared and stored in a bottle covered with aluminium foil to protect the reagent from light. A spectrophotometer DU 720 (Beckman Coulter Inc. Pasadena, CA, U.S.A) was set at $340 \mathrm{~nm}$ with $1.5 \mathrm{~mL}$ OPA reagent $+0.2 \mathrm{~mL}$ Milli-Q water. Serine standard solutions of $200 \mu \mathrm{L}$ 
of $50 \mathrm{mg} / \mathrm{L}, 100 \mathrm{mg} / \mathrm{L}, 150 \mathrm{mg} / \mathrm{L}$ and $200 \mathrm{mg} / \mathrm{L}$ were added to $1.5 \mathrm{~mL}$ OPA reagent and mixed. The solutions were measured with the spectrophotometer after standing for $3 \mathrm{~min}$. The samples were pipetted into the Amicon Ultra-0.5 $10 \mathrm{~K}$ Centrifugal Filter Units (Millipore, USA) and centrifuged for $20 \mathrm{~min}$ at 14,000 g. All measurements were performed in triplicate.

\subsubsection{Size exclusion chromatography (SEC)}

The peptide profile after digestion was analyzed using SEC Ultimate 3000 UHPLC system (Thermo Scientific, MA, U.S.A.) equipped with a TSKgel G2000SWxl column (Tosoh Bioscience LLC, PA, U.S.A.). $0.1 \mathrm{~mL}$ sample was used for analysis. The running buffer consisted of acetonitrile and 70\% Milli-Q water with $0.1 \%$ Trifluoro Acetic Acid (TFA). The flow rate of the running buffer was $1 \mathrm{~mL} / \mathrm{min}$ and the UV detector was set at $214 \mathrm{~nm}$. In order to standardize the molecular weight range of the chromatographic separation, the following purified proteins and amino acids were used for calibration: carbonic anhydrase (29 kDa), $\alpha-$ lactalbumin $(14.1 \mathrm{kDa})$, aprotinin $(6.51 \mathrm{kDa})$, insulin $(5.7 \mathrm{kDa})$, bacitracin $(1.42 \mathrm{kDa})$ and phenylalanine (165 Da) (Sigma-Aldrich, Inc., St. Louis, MO, U.S.A.). The area under the curves was determined and the relative area for each segment calculated. All measurements were done in triplicate.

\subsection{Results and discussions}

\subsubsection{Protein yield and purity}

When extracting quinoa protein in a $\mathrm{pH}$ range of $8-11$, a protein purity of $90-93 \%$ was obtained (Figure 3.1). These values are the highest reported in literature so far (Avila Ruiz et al., 2016a; Aora et al., 2009; Abugoch et al., 2008; Lindeboom, 2005; Aluko \& Monu, 2003; Chauhan et al., 1999). In our previous study, we used a similar extraction protocol, only the alkalinization time was longer and the precipitation $\mathrm{pH}$ lower, resulting in a lower protein purity (82-88 \%) (Avila Ruiz et al., 2016a). Protein yield increased from 24 to 37\% when increasing the extraction $\mathrm{pH}$ from 8 to 11 . These values are lower than in our previous study (35-50\% going from extraction $\mathrm{pH} 8$ to 11 ) but they also increased with extraction $\mathrm{pH}$. For industrial production of quinoa protein isolates, this means that the extraction $\mathrm{pH}$ would need to be controlled carefully. 


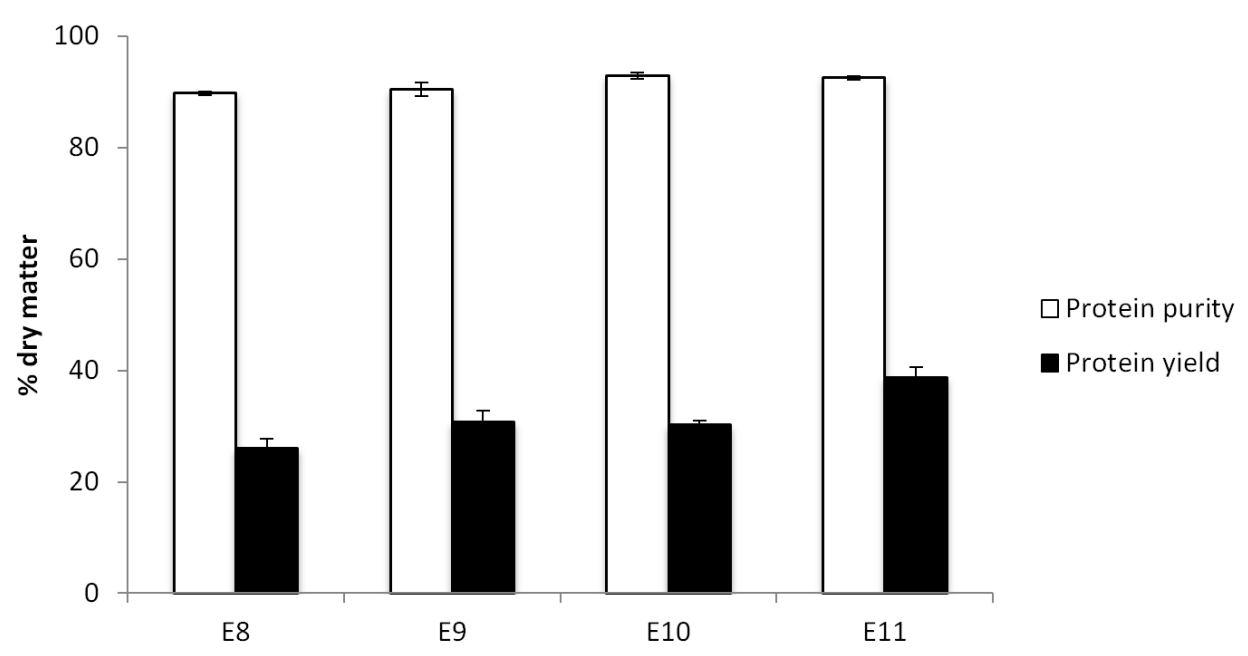

Figure 3.1. Protein yield and protein purity on dry matter basis of the quinoa protein isolates E8, E9, E10 and E11. Error bars represent the standard deviation based on duplicate extraction experiments.

\subsubsection{Thermal properties}

Unprocessed and processed 20\% QPI suspensions showed an endotherm from 96 to $102{ }^{\circ} \mathrm{C}$ (denaturation temperature range) (Figures A3.1, A3.2, A3.3, A3.4 and A3.5), which is in line with denaturation temperatures $\left(T_{d}\right)$ previously found for quinoa, amaranth and sunflower protein. These denaturation temperatures have been attributed to 11S globulin (Abugoch et al., 2008; Castellani et al., 1998; Avila Ruiz et al., 2016a; Martínez \& Añón, 1996; Molina et al., 2004). Therefore, we assume that the endotherm found in our study also mainly corresponds to $11 \mathrm{~S}$ globulin. There was no significant change in $T_{d}$ with processing temperature, but $T_{d}$ decreased with increasing extraction $\mathrm{pH}$. This decrease was also observed by Martínez \& Añón (1996) for amaranth protein and indicates that protein is less heat-stable when extracted at higher pH (Martínez \& Añón, 1996).

The denaturation enthalpy of the unprocessed QPI suspensions decreased considerably from 13.5 to $3.8 \mathrm{~J} / \mathrm{g}$ protein with increasing extraction $\mathrm{pH}$ (Figure 3.2). This trend has also been observed in several other studies on quinoa, amaranth and sunflower protein, showing that the protein is more denatured at higher extraction pH (Abugoch et al., 2008; Castellani et al., 1998; Avila Ruiz et al., 2016a; Martínez \& Añón, 1996; Molina et al., 2004)17. When QPI suspensions were processed at 90 and $120^{\circ} \mathrm{C}$, the denaturation enthalpy was reduced to $0-3.4$ $\mathrm{J} / \mathrm{g}$ protein. However, the enthalpy was significantly higher after processing at $60{ }^{\circ} \mathrm{C}$ than at 20 ${ }^{\circ} \mathrm{C}$ for E9, E10 and E11. 
A
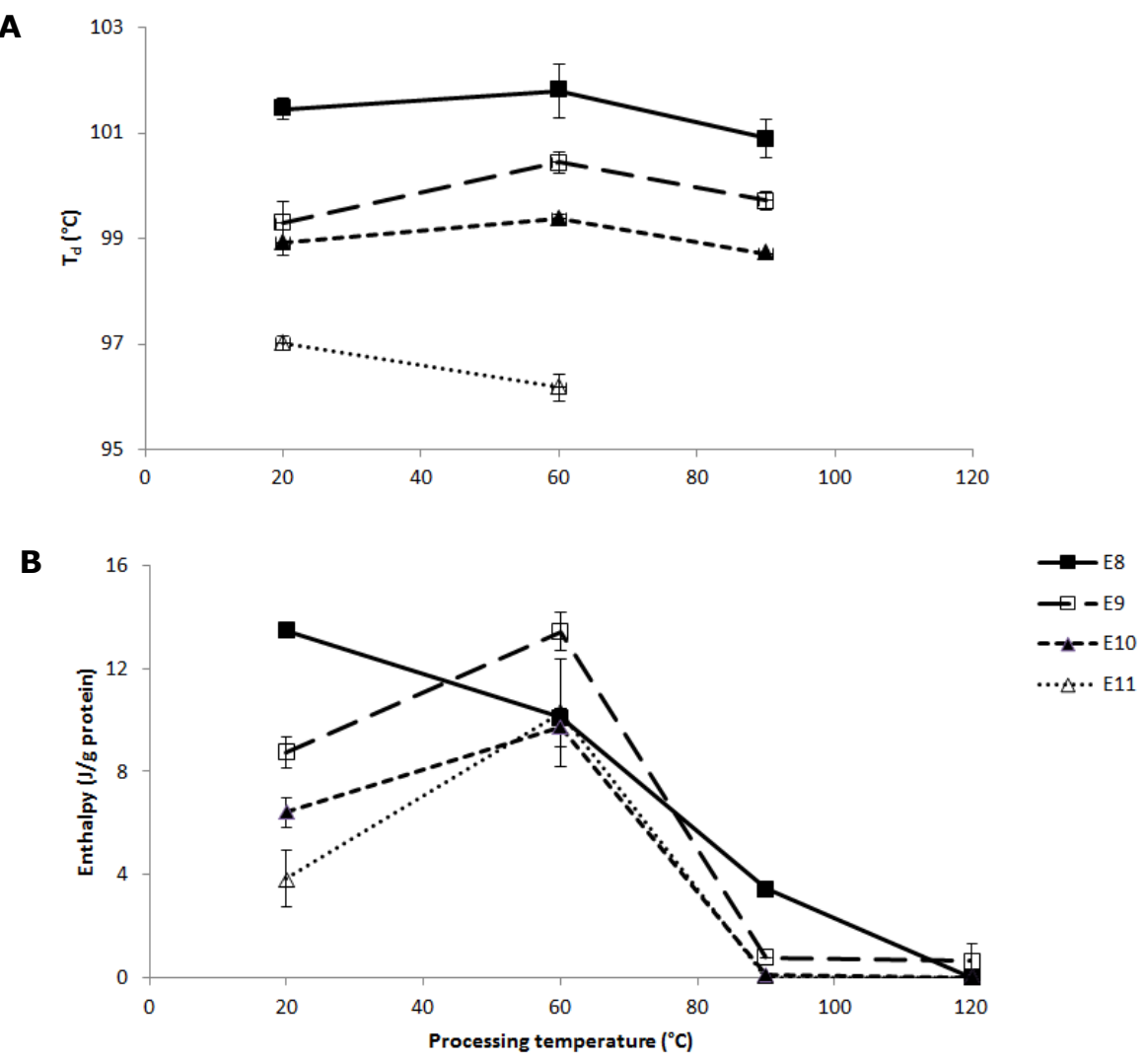

Figure 3.2. (A) Denaturation temperature (Td) and (B) denaturation enthalpy $(\Delta H)$ of $20 \%$ w/w suspensions of QPI E8, E9, E10 and E11 after processing at different temperatures. Data were obtained from DSC measurements.

Martínez \& Añón (1996) have summarized the notion of denaturation enthalpy to be the result of endothermal processes, e.g. disruption of hydrogen bonds, and exothermal processes, e.g. protein aggregation and disruption of hydrophobic interactions. The higher denaturation enthalpy (or transition enthalpy) of E9, E10 and E11 at $60{ }^{\circ} \mathrm{C}$ might thus indicate a conformation of the protein that was stabilized by a greater extent of hydrophobic interactions and/or hydrogen bonds and that cost more transition energy than at 20,90 or $120{ }^{\circ} \mathrm{C}$. The exception was E8, which showed a continuous decrease in enthalpy from 20 to $120{ }^{\circ} \mathrm{C}$. Based on the notion of denaturation enthalpy of Martínez \& Añón (1996) it might be that at an extraction $\mathrm{pH}$ of 8 the protein initially contained a higher degree of hydrophobic interactions and/or hydrogen bonds as compared to the protein obtained at other extraction $\mathrm{pH}$ values. These molecular interactions might have decreased in number from a processing temperature of 20 to $60{ }^{\circ} \mathrm{C}$ in contrast to the other extraction $\mathrm{pH}$ values, where the protein initially had undergone more extensive conformational changes due stronger alkaline extraction conditions, resulting in a different degree of molecular interactions after processing at $60^{\circ} \mathrm{C}$. In summary, the effect of processing temperature on the thermal properties of QPIs seemed to depend on the protein 
properties predetermined by the extraction $\mathrm{pH}$.

\subsubsection{Protein fractions}

SDS profiles showed major bands at $50 \mathrm{kDa}$ for all QPIs and at $37 \mathrm{kDa}$ for E8, E9 and E10 (Figure 3.3). The bands of E8 were the most intense and decreased in intensity with increasing extraction $\mathrm{pH}$. The SDS profiles were similar to the ones of previous quinoa protein studies, suggesting a correspondence of the bands at $50 \mathrm{kDa}$ to $11 \mathrm{~S}$ globulin (Abugoch et al., 2008; Avila Ruiz et al., 2006a; Brinegar \& Goundan, 1993). Furthermore, bands at $37 \mathrm{kDa}$ might correspond to the acidic subunit and bands at $23 \mathrm{kDa}$ might be attributed to the basic subunit of $11 \mathrm{~S}$ globulin. Alkali is known to cause disulfide bond cleavage, resulting in the dissociation of $11 \mathrm{~S}$ globulin into acidic and basic subunits of $32-39 \mathrm{kDa}$ and $22-23 \mathrm{kDa}$, respectively (Kinsella et al., 1985).

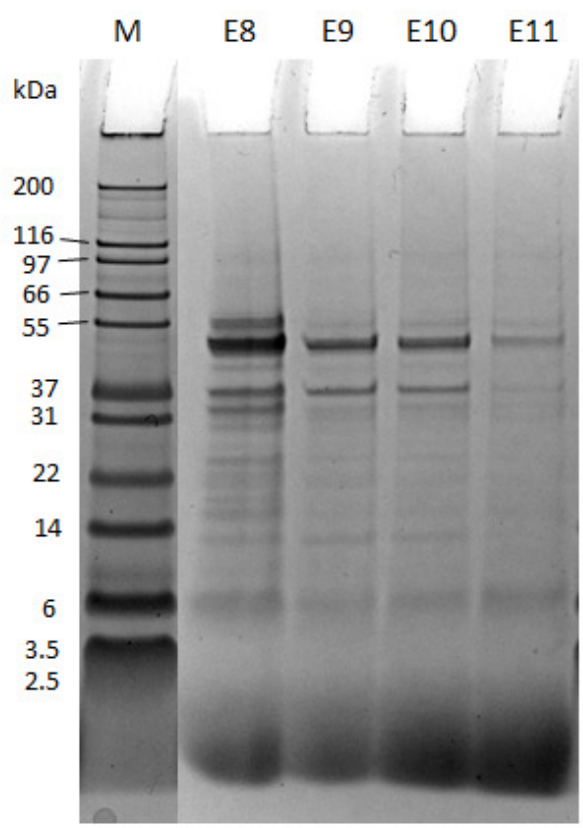

Figure 3.3. SDS-PAGE profile of the unprocessed QPI's E8, E9, E10 and E11. Lane M: molecular weight marker.

After heat processing, the SDS profiles showed less bands with less intensity for all QPIs (Figure 3.4). In some lanes specific bands were even not visible anymore. 


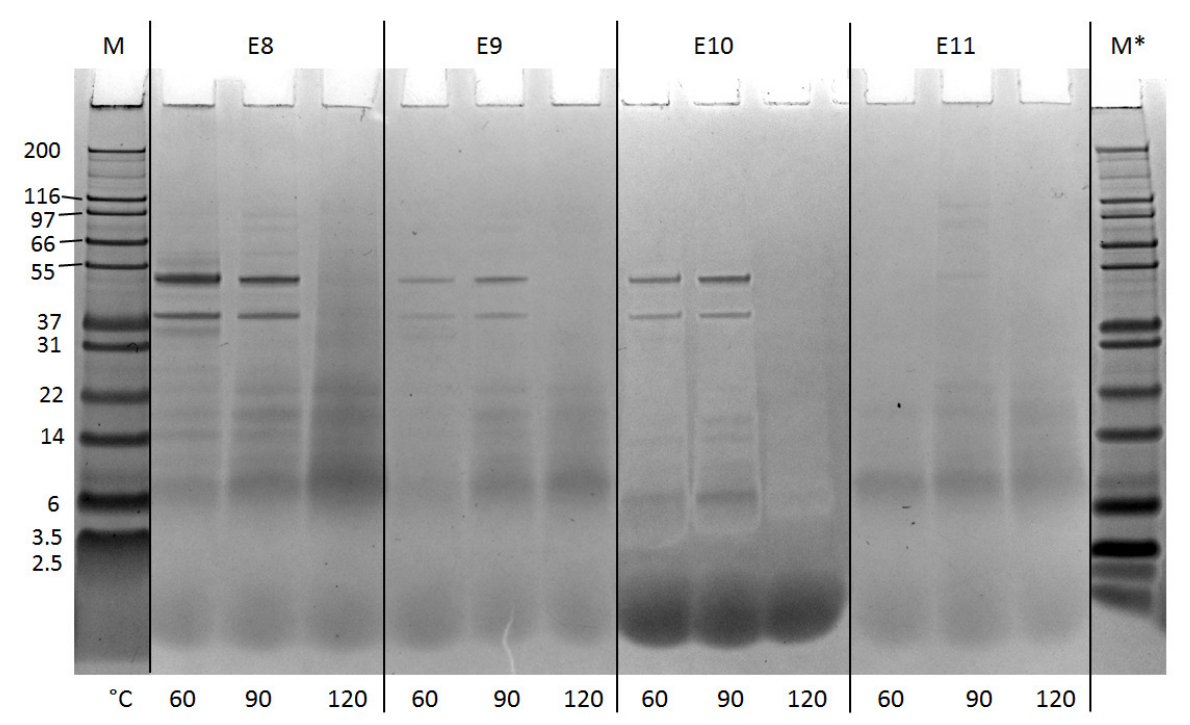

Figure 3.4. SDS-PAGE profile of the QPIs E8, E9, E10 and E11 heat-treated for 30 min at 60,90 and $120{ }^{\circ} \mathrm{C}$. Lane M: molecular weight marker. The gel of E10 seems to be overloaded at the bottom. E10 was run on a different gel and is shown in Figure A3.6.

The disappearance of bands with increasing processing temperature indicates enhanced protein aggregation to protein particles larger than $200 \mathrm{kDa}$ or to insoluble protein particles that remained in the pellet after centrifuging the heat-processed protein suspensions. Protein aggregation might have resulted from increased protein dissociation and subunit interactions and re-association to larger (insoluble) aggregates as reported for heat-processed soy protein (0 - $30 \mathrm{~min}$ at 80 and $100{ }^{\circ} \mathrm{C}$ ) (Utsumi et al., 1984; Wolf \& Tamura, 1969). DSC results showed higher denaturation enthalpies of the unprocessed and $60{ }^{\circ} \mathrm{C}$ unprocessed QPI suspensions compared to the suspensions processed at 90 and $120{ }^{\circ} \mathrm{C}$. As described before, the higher enthalpies might result from more hydrophobic interactions, hydrogen bonds but also from increased protein aggregation, according to Martínez \& Añón (1996). Based on the results of SDS and DSC, it seems likely that protein aggregation leads to insoluble particles remaining in the pellet, especially at $120{ }^{\circ} \mathrm{C}$ (less protein on the SDS gels), while the aggregates seem to be less capable to undergo a heat-induced phase transition up to a temperature of $140{ }^{\circ} \mathrm{C}$ (maximum temperature reached during DSC measurements) compared to protein treated at 60 ${ }^{\circ} \mathrm{C}$.

\subsubsection{In vitro protein digestibility of quinoa protein isolates}

Gastric digestibility of the QPIs was studied in vitro simulating physiological conditions and was indicated as the degree of protein hydrolysis (\% peptide bonds cleaved by pepsin of total bonds). The degree of hydrolysis (DH) of unprocessed and processed 5\% QPI suspensions 
sharply increased within the first 20 min and further increased at a slower rate in the following hours (Figure 3.5). The hydrolysis profiles compare to those of whey protein and egg white protein obtained by Luo et al. (2015) at the same protein concentration, and under the same digestion and measurement conditions. When interpolating the DH values of the QPI suspensions treated at $90{ }^{\circ} \mathrm{C}$ to a digestion time of $3 \mathrm{~h}$, the $\mathrm{DH}$ of quinoa protein was slightly lower $(13-14 \%)$ than the DH of whey protein $(15 \%)$ but higher than the DH of egg white protein $(11 \%)$, both pre-treated for $30 \mathrm{~min}$ at $90{ }^{\circ} \mathrm{C}$ and digested for $3 \mathrm{~h}$.
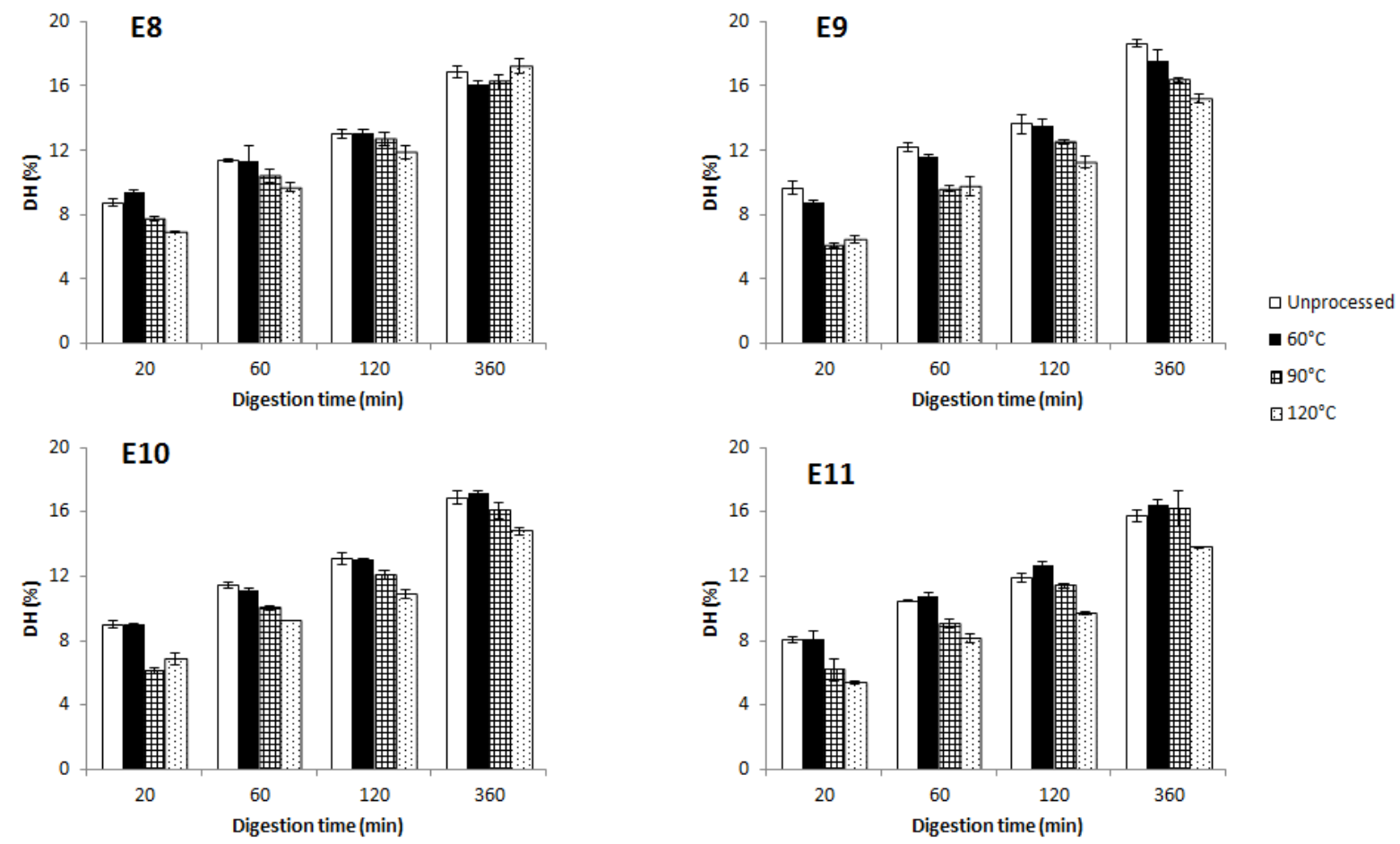

Figure 3.5. Degree of hydrolysis (DH) of 5\% w/w suspensions of QPI E8, E9, E10 and E11 processed at different temperatures and subsequently digested for different time periods.

HPLC chromatograms showed that when digesting unprocessed and processed QPI suspensions for 5 - 360 min higher amounts of peptides ranging from 0.5 to $5 \mathrm{kDa}$ were obtained (Figures 3.6, A3.7, A3.8 and A3.9). The peaks in the molecular size range of $0.5-5 \mathrm{kDa}$ became larger and moved to a smaller size range with increasing in vitro digestion time. As digestion progressed, pepsin cleaved increasingly more peptide bonds, resulting in smaller molecules. When comparing processing temperatures, the chromatograms did not significantly change from 20 to $60{ }^{\circ} \mathrm{C}$. However, at 90 and $120{ }^{\circ} \mathrm{C}$, the response areas were significantly smaller compared to 20 and $60{ }^{\circ} \mathrm{C}$. This is most clearly visible after 5 and $20 \mathrm{~min}$ of digestion. This finding could be confirmed by DH measurements (Figure 3.5): the DH was reduced overall at 90 and $120{ }^{\circ} \mathrm{C}$ compared to 20 and $60{ }^{\circ} \mathrm{C}$. Similar observations were made for lupine protein 
(Pelgrom et al., 2014). A heat treatment at $60{ }^{\circ} \mathrm{C}$ for $30 \mathrm{~min}$ did not change the digestibility of lupine protein compared to the untreated sample, while a heat treatment at $90{ }^{\circ} \mathrm{C}$ for $30 \mathrm{~min}$ did reduce the digestibility. The reduction in the $\mathrm{DH}$ at higher processing temperature was enhanced at higher extraction $\mathrm{pH}$.
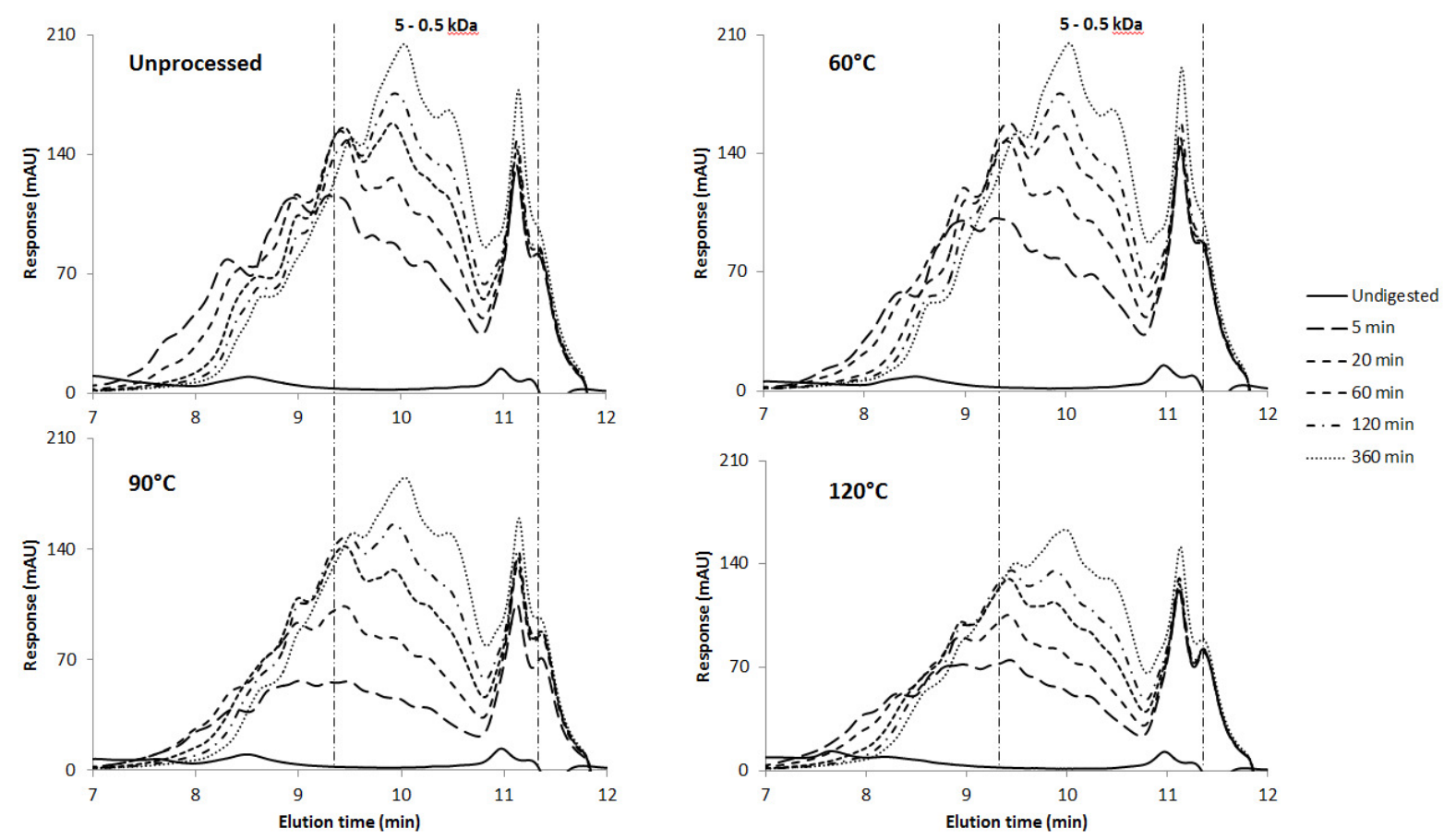

Figure 3.6. HPLC chromatograms of 5\% w/w suspensions of QPI E9 processed at different temperatures and subsequently digested for different time periods. Size exclusion chromatography is used for separation. This means that larger peptides have a low elution time. See Figures 3.14, 3.15, 3.16 for the HPLC chromatograms of E8, E10 and E11.

These results suggest that pepsin was less effective after heat-treatment of the QPI suspensions. This might be explained by the heat-induced change in protein conformation, molecular interactions and protein aggregation as indicated by DSC and SDS results. Increased protein aggregation after the heat treatments might have reduced the accessibility of pepsin. Impairment of protein digestibility for pepsin has already been previously correlated with stronger protein crosslinking when cooking sorghum (Zhao et al., 2008). The in vitro digestibility of sorghum protein using pepsin has therefore been validated as an indicator for the degree of protein crosslinking. This relation might also be valid for quinoa protein.

If this is the case, the fact that the reduction in the DH at higher processing temperature was enhanced at higher extraction $\mathrm{pH}$ can be explained with increased protein crosslinking. This might also be deduced from SDS results: with an increasing extraction $\mathrm{pH}$ and processing temperature, the degree of protein aggregation, possibly as a result of protein crosslinking, 
seemed to be higher. However, DSC results implied that the protein suspensions from a high extraction $\mathrm{pH}(10$ and 11$)$ and processing temperature $\left(90\right.$ and $\left.120{ }^{\circ} \mathrm{C}\right)$ were only slightly capable or not capable at all to undergo a heat-induced phase transition. Therefore, not a greater extent of protein aggregation or crosslinking seemed to be impairing enzyme action more under these harsher conditions, but a more heat-resistant type of protein aggregation or crosslinking.

The extraction $\mathrm{pH}$ had almost no influence on the $\mathrm{DH}$ when comparing $\mathrm{pH}$ values of the unprocessed suspensions and of the processed suspensions at 60 and $90{ }^{\circ} \mathrm{C}$ (Figure 3.5). This means that the effects of extraction $\mathrm{pH}$ observed on the physical properties of unprocessed QPIs and processed QPIs at 60 and $90{ }^{\circ} \mathrm{C}$ were not clearly transferred to in vitro gastric digestibility. At $120^{\circ} \mathrm{C}$, the rate of $\mathrm{DH}$ was only slightly reduced at extraction $\mathrm{pH} 11$ compared to the other extraction $\mathrm{pH}$ values. These results show a bigger impact of processing temperature on the $\mathrm{DH}$ of quinoa protein compared to extraction $\mathrm{pH}$.

We conclude that heat treatment for $30 \mathrm{~min}$ at 90 and $120^{\circ} \mathrm{C}$ impairs in vitro gastric digestibility of protein in QPIs.

\subsubsection{Gastric in vitro protein digestibility of whole quinoa flour}

To examine how protein digestibility in QPIs compares to that in whole quinoa flour, we performed the digestibility study with wholemeal quinoa flour at the same protein concentration. The DH values also increased in time and looked similar to that of the QPIs. However, the DH values were overall lower, especially at $120^{\circ} \mathrm{C}$ (Figure 3.7). This reduction in DH might be due to the other components present (in higher amounts) in the quinoa flour (mainly starch, fiber and fat). The mere presence of much higher amounts of starch and fiber in the quinoa flour compared to the QPIs might be the responsible factor, but also the behaviour of these components at the different processing temperatures might have had an impact on digestibility (Lev et al., 2012). The gelatinization of quinoa starch starts from 45 to $54{ }^{\circ} \mathrm{C}$, peaks from 51 to $62{ }^{\circ} \mathrm{C}$ and concludes from 64 to $71{ }^{\circ} \mathrm{C}$ (Bhargava \& Srivastava, 2013). At processing temperatures of 60 and $90^{\circ} \mathrm{C}$, there was no large difference in the decrease in $\mathrm{DH}$ compared to the protein isolates, indicating that gelatinization did not affect protein digestibility significantly. There was a larger drop in $\mathrm{DH}$ from 90 to $120^{\circ} \mathrm{C}$ for the quinoa flour compared to the protein isolates. As starch gelatinization did not seem to have an impact on digestibility at lower temperatures, it is possible that at higher temperatures the gelatinized starch interacted with denatured protein $\left(T_{d}=96-102{ }^{\circ} \mathrm{C}\right)$, thereby hindering enzyme action. Another 
explanation might be that in contrast to the protein in the flour, the protein in the protein isolates underwent conformational changes during the extraction, which limited the effect of processing temperature on protein digestibility.

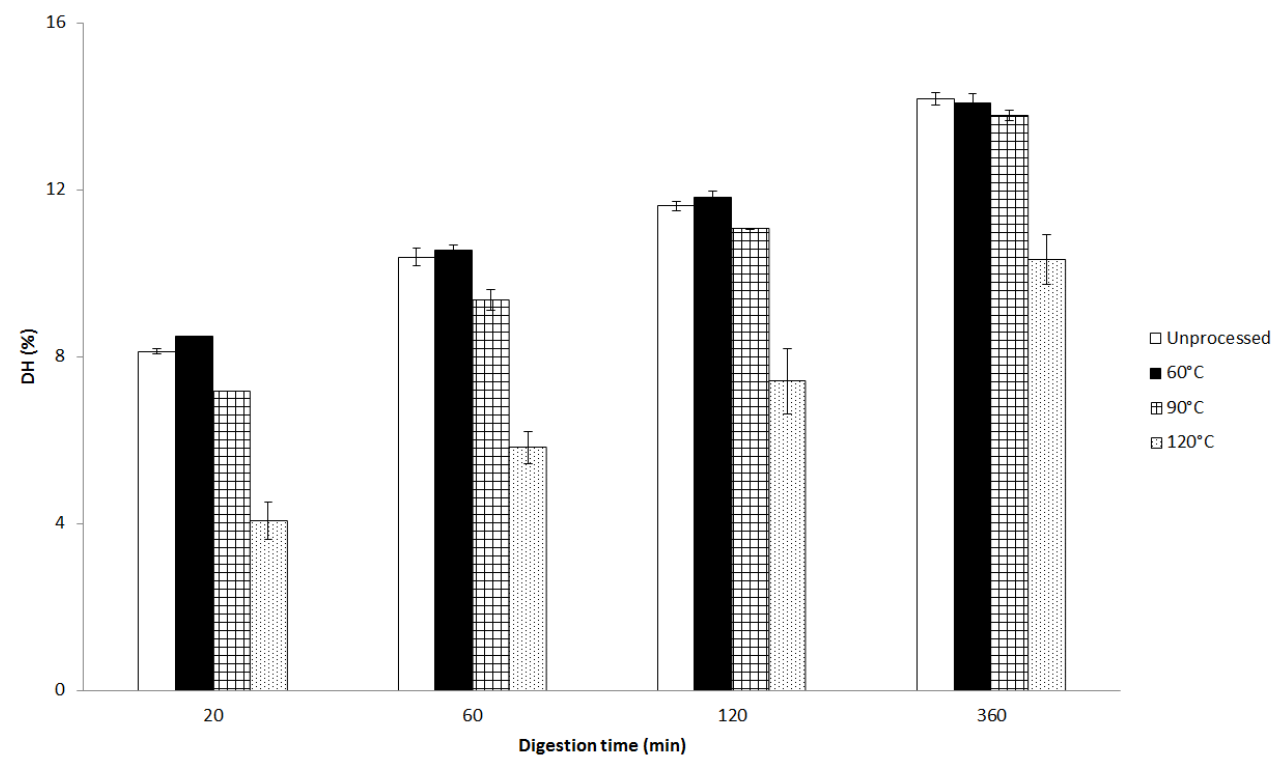

Figure 3.7. Degree of hydrolysis $(\mathrm{DH})$ of wholemeal quinoa flour $(5 \% \mathrm{w} / \mathrm{w}$ protein) processed at different temperatures and subsequently digested for different time periods.

\subsection{Conclusions}

Using the extraction protocol from the present study, we could achieve a very high protein purity, but at the expense of a low protein yield. The degree of denaturation and molecular weight profiles of the QPIs were strongly affected by processing temperature and extraction $\mathrm{pH}$, individually and combined. For QPI's, extraction $\mathrm{pH}$ and processing temperature showed an interactive effect on in vitro gastric digestibility of the protein. Extracting protein from quinoa flour results in a higher protein digestibility when compared to keeping the protein in the flour. For applications, the present findings mean that extraction and processing conditions need to be controlled to optimize protein digestibility. Future research could investigate other functional properties of quinoa protein but also examine ileal and in vivo protein digestibility under various conditions to verify the present findings in more real-life digestion conditions.

\subsection{References}

Abugoch, L.E., Romero, N., Tapia, C.A., Silva, J., \& Rivera, M. (2008). Study of some physicochemical and functional properties of quinoa (Chenopodium quinoa willd) protein isolates. Journal of Agricultural of Food Chemistry, 56(12),4745-4750. 
Aluko, R.E., \& Monu, E. (2003). Functional and bioactive properties of quinoa seed protein hydrolysates. Journal of Food Science, 68(4), 1254-1258.

Aora, J.C.C., \& Alvarado, K. (2009). Aislados proteínicos de granos altoandinos chenopodiaceas; quinua "chenopodium quinoa" - cañahua "chenopodium pallidicaule" por precipitación isoeléctrica. Revista Boliviana de Química, 26(1), 12-20.

Avila Ruiz, G., Xiao, W., van Boekel, M., Stieger, M., \& Minor, M. (2016a). Effect of extraction $\mathrm{pH}$ on yield, denaturation properties and functionality of quinoa protein (Chenopodium quinoa Willd). Food Chemistry, 209, 203-210.

Avila Ruiz, G., Xiao, W., van Boekel, M., Stieger, M., \& Minor, M. (2016). Effect of extraction $\mathrm{pH}$ on heat-induced aggregation, gelation and microstructure of protein from sweet quinoa (Chenopodium quinoa Willd). Food Chemistry, 209, 203-210.

Becker, R., Wheeler, E.L., Lorenz, K., Stafford, A.E., Grosjean, O.K., Betschart, A.A., \& Saunders. R.M. (1981). A Compositional Study of Amaranth Grain. Journal of Food Science, 46(4), 1175-1180.

Bhargava, A., \& Srivastava, S. (2013). Chemistry. In: Bhargava A, Srivastava S (eds) Quinoa - Botany, Production and Uses. CABI, Oxfordshire, pp. 185-239.

Brinegar, C., \& Goundan, S. (1993), Isolation and characterization of chenopodin, the 118 seed storage protein of Quinoa (Chenopodium quinoa). Journal of Agricultural and Food Chemistry, 41(2), 182-185.

Budryn, G., Nebesny, E., \& Rachwał, D. (2013). Pepsin Digestibility and Antioxidant Activity of Egg White Protein in Model Systems with Green Coffee Extract. International Journal of Food Properties, 17(7), 1529-1546.

Chauhan, G.S., Cui, W., \& Eskin, N.A.M. (1999). Effect of saponin on the surface properties of quinoa proteins. International Journal of Food Properties, 2(1), 13-22.

Casey, E.J., \& Laidler, K.J. (1951). The Kinetics and Mechanism of the Heat Inactivation of Pepsin1. Journal of the American Chemical Society, 73(4), 1455-1457.

Castellani, O.F., Martínez, E.N., Añón, M.C. (1998). Structural Modifications of an Amaranth Globulin Induced by $\mathrm{pH}$ and $\mathrm{NaCl}$. Journal of Agricultural and Food Chemistry, 46(12), 
4846-4853.

Guo, X., Yao, H., \& Chen, Z. (2007). Effect of heat, rutin and disulfide bond reduction on in vitro pepsin digestibility of Chinese tartary buckwheat protein fractions. Food Chemistry, 102(1), 118-122.

Hoppe, A., Jung, S., Patnaik, A., \& Zeece, M.G. (2013). Effect of high pressure treatment on egg white protein digestibility and peptide products. Innovative Food Science \& Emerging Technologies, 17, 54-62.

Kinsella, J.E., Damodaran, S., German, B., Wilcke, A.M.A.L. (1985). V - Physicochemical and Functional Properties of Oilseed Proteins with Emphasis on Soy Proteins. In: New Protein Foods. Academic Press, pp. 107-179.

Kong, F., \& Singh, R.P. (2009). Modes of Disintegration of Solid Foods in Simulated Gastric Environment. Food Biophysics, 4(3), 180-190.

Lev, E.L., Italianskaya, J., \& Fadeeva, I. (2012). Gel Electrophoresis as a Tool to Study Polymorphism and Nutritive Value of the Seed Storage Proteins in the Grain Sorghum. In: Mageldin S (ed) Gel Electrophoresis - Advanced Techniques. InTech, Russia, pp. 463-478.

Limburg, H., \& Masterbroek, H.D. (1997). Breeding high yielding lines of Chenopodium quinoa Willd. with saponin free seed. In: Stølen O, Bruhn K, Pithan K, Hill J (eds) Proc COST 814 workshop on Small Grain Cereals and Pseudo-Cereals, Copenhagen, 24 February 1997. pp 103-114.

Lindeboom, N. (2005). Studies on the characterization, biosynthesis and isolation of starch and protein from quinoa (Chenopodium quinoa Willd.). University of Saskatchewan, Canada (PhD Thesis).

Luo, Q., Boom, R.M., \& Janssen, A.E.M. (2015). Digestion of protein and protein gels in simulated gastric environment. LWT - Food Science and Technology, 63(1), 161-168.

Mäkinen, O., Zannini, E., \& Arendt, E. (2015). Modifying the Cold Gelation Properties of Quinoa Protein Isolate: Influence of Heat-Denaturation $\mathrm{pH}$ in the Alkaline Range. Plant Foods for Human Nutrition, 70(3), 250-256. 
Martínez, E.N., \& Añón, M.C. (1996). Composition and Structural Characterization of Amaranth Protein Isolates. An Electrophoretic and Calorimetric Study. Journal of Agricultural and Food Chemistry, 44(9), 2523-2530.

Mastebroek, H.D., van Loo, E.N., \& Dolstra, O. (2002). Combining ability for seed yield traits of Chenopodium quinoa breeding lines. Euphytica, 125(3), 427-432.

Mertz, E.T., Hassen, M.M., Cairns-Whittern, C., Kirleis, A.W., Tu, L., \& Axtell, J.D. (1984). Pepsin digestibility of proteins in sorghum and other major cereals. Proceedings of the National Academy of Sciences of the United States of America, 81, 1-2.

Mokrane, H., Amoura, H., Belhaneche-Bensemra, N., Courtin, C.M., Delcour, J.A., \& Nadjemi, B. (2010). Assessment of Algerian sorghum protein quality [Sorghum bicolor (L.) Moench] using amino acid analysis and in vitro pepsin digestibility. Food Chemistry, 121(3), 719-723.

Molina, M.I., Petruccelli, S., \& Añón, M.C. (2004). Effect of pH and Ionic Strength Modifications on Thermal Denaturation of the 11S Globulin of Sunflower (Helianthus annuus). Journal of Agricultural and Food Chemistry, 52(19), 6023-6029.

Pelgrom, P.J.M., Wang, J., Boom, R.M., Schutyser, M.A.I. (2015). Pre- and post-treatment enhance the protein enrichment from milling and air classification of legumes. Journal of Food Engineering, 155, 53-61.

Pelgrom, P.J.M., Berghout, J.A.M., van der Goot, A.J., Boom, R.M., \& Schutyser, M.A.I. (2014). Preparation of functional lupine protein fractions by dry separation. LWT - Food Science and Technology, 59(2), 680-688.

Sarker, A.K., Saha, D., Begum, H., Zaman, A., \& Rahman, M.M. (2015). Comparison of cake compositions, pepsin digestibility and amino acids concentration of proteins isolated from black mustard and yellow mustard cakes. AMB Express, 5:22.

Utsumi, S., Damodaran, S., \& Kinsella, J.E. (1984). Heat-induced interactions between soybean proteins: preferential association of $11 \mathrm{~S}$ basic subunits and .beta. subunits of 7S. Journal of Agricultural and Food Chemistry, 32(6), 1406-1412.

Valenzuela, C., Abugoch, L., Tapia, C., Gamboa, A. (2013). Effect of alkaline extraction on 
the structure of the protein of quinoa (Chenopodium quinoa Willd.) and its influence on film formation. International Journal of Food Science \& Technology, 48, 843-849.

Wolf, W.J., \& Tamura, T. (1969). Heat Denaturation of Soybean 11S Protein. Cereal Chemistry, 46, 331-343

Zhao, R., Bean, S.R., Ioerger, B.P., Wang, D., \& Boyle, D.L. (2008). Impact of Mashing on Sorghum Proteins and Its Relationship to Ethanol Fermentation. Journal of Agricultural and Food Chemistry, 56(3), 946-953. 


\subsection{Appendix}

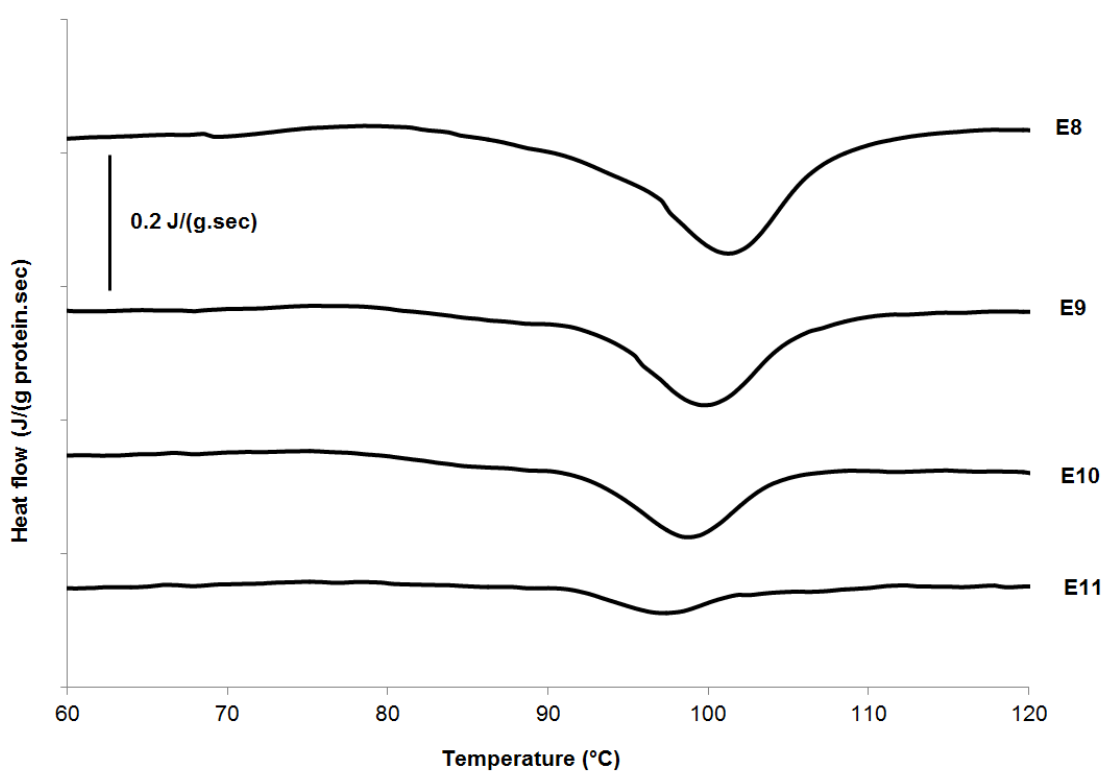

Figure A3.1. DSC thermograms of untreated $20 \%$ w/w suspensions of QPI E8, E9, E10 and E11.

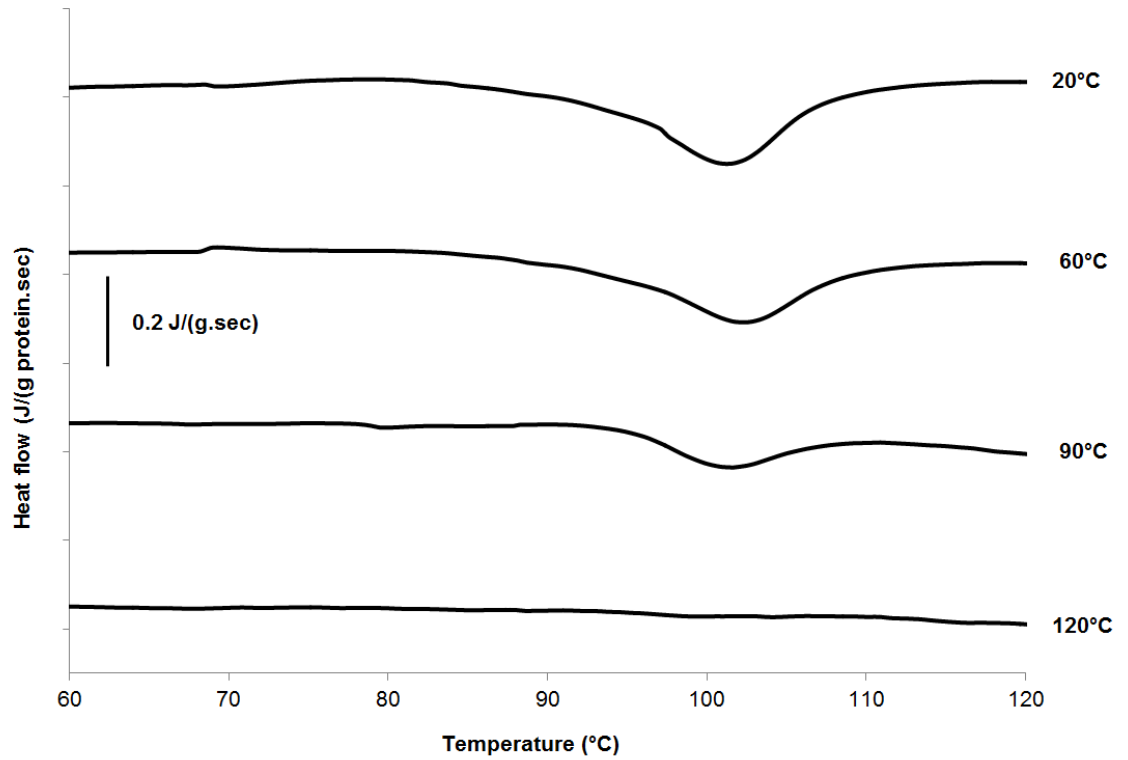

Figure A3.2. DSC thermograms of $20 \%$ w/w suspensions of QPI E8 after processing at different temperatures. 


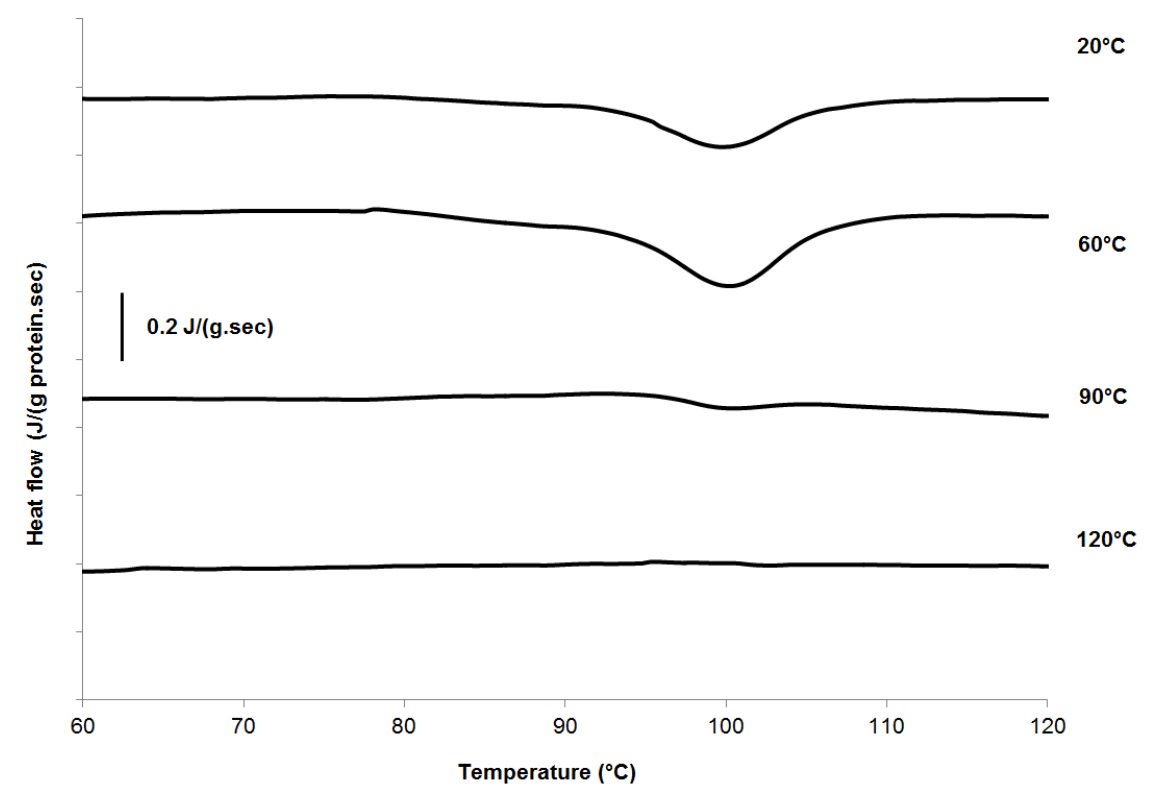

Figure A3.3. DSC thermograms of $20 \%$ w/w suspensions of QPI E9 after processing at different temperatures.

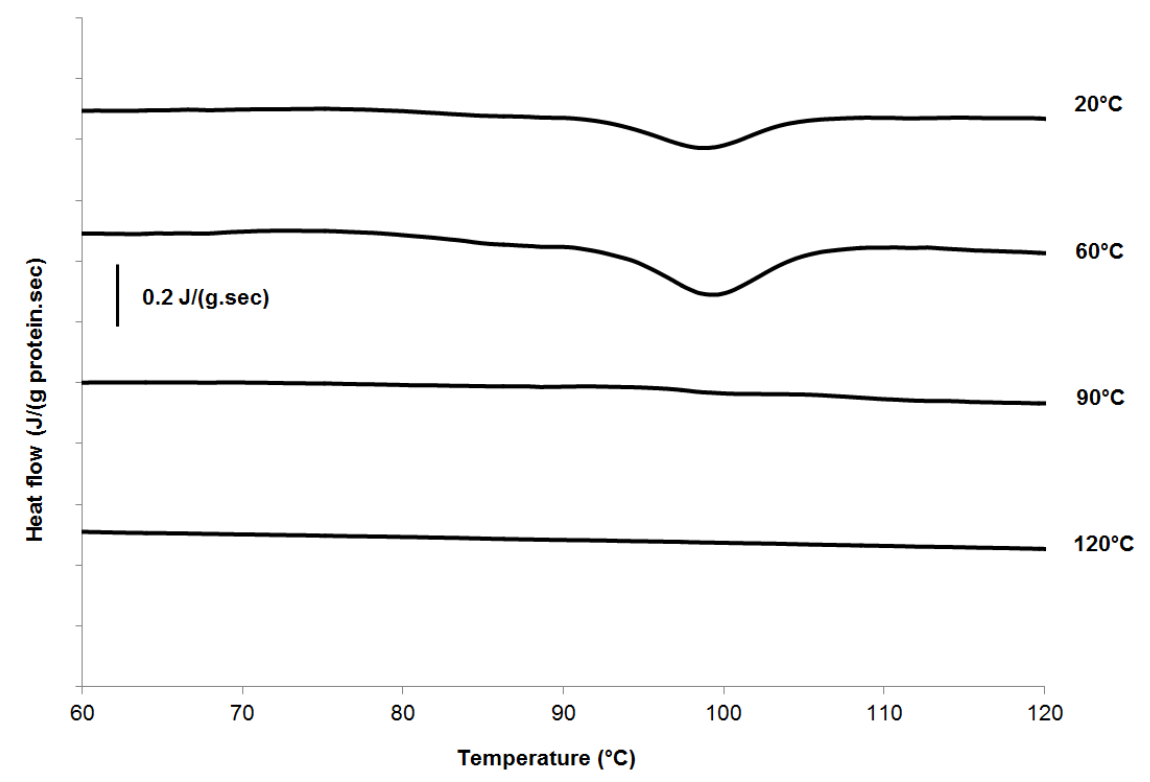

Figure A3.4. DSC thermograms of $20 \%$ w/w suspensions of QPI E10 after processing at different temperatures. 


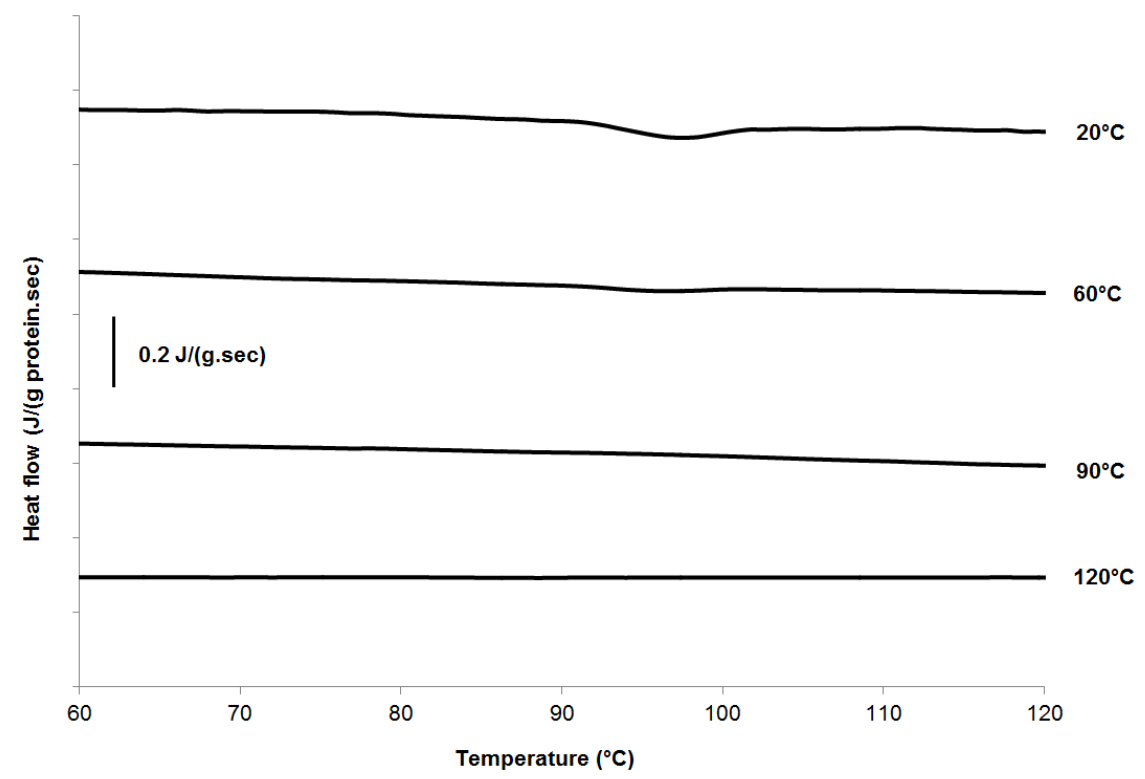

Figure A3.5. DSC thermograms of 20\% w/w suspensions of QPI E11 after processing at different temperatures.

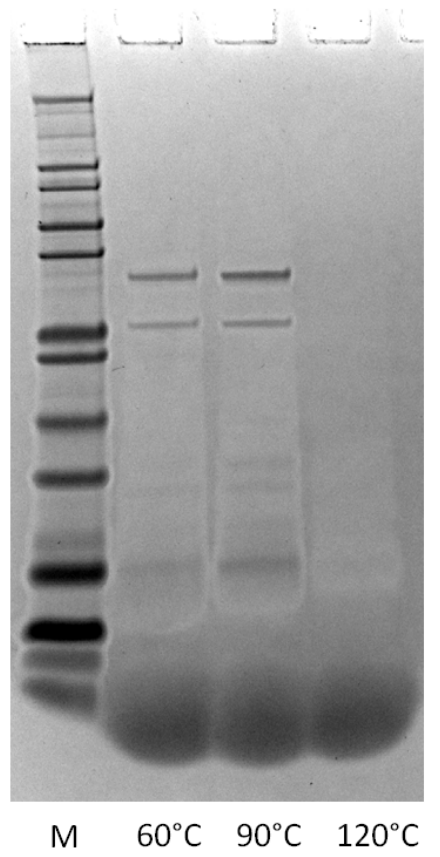

Figure A3.6. SDS-PAGE profile of the QPIs E10 heat-treated for $30 \mathrm{~min}$ at 60,90 and $120^{\circ} \mathrm{C}$. Lane M: molecular weight marker. 

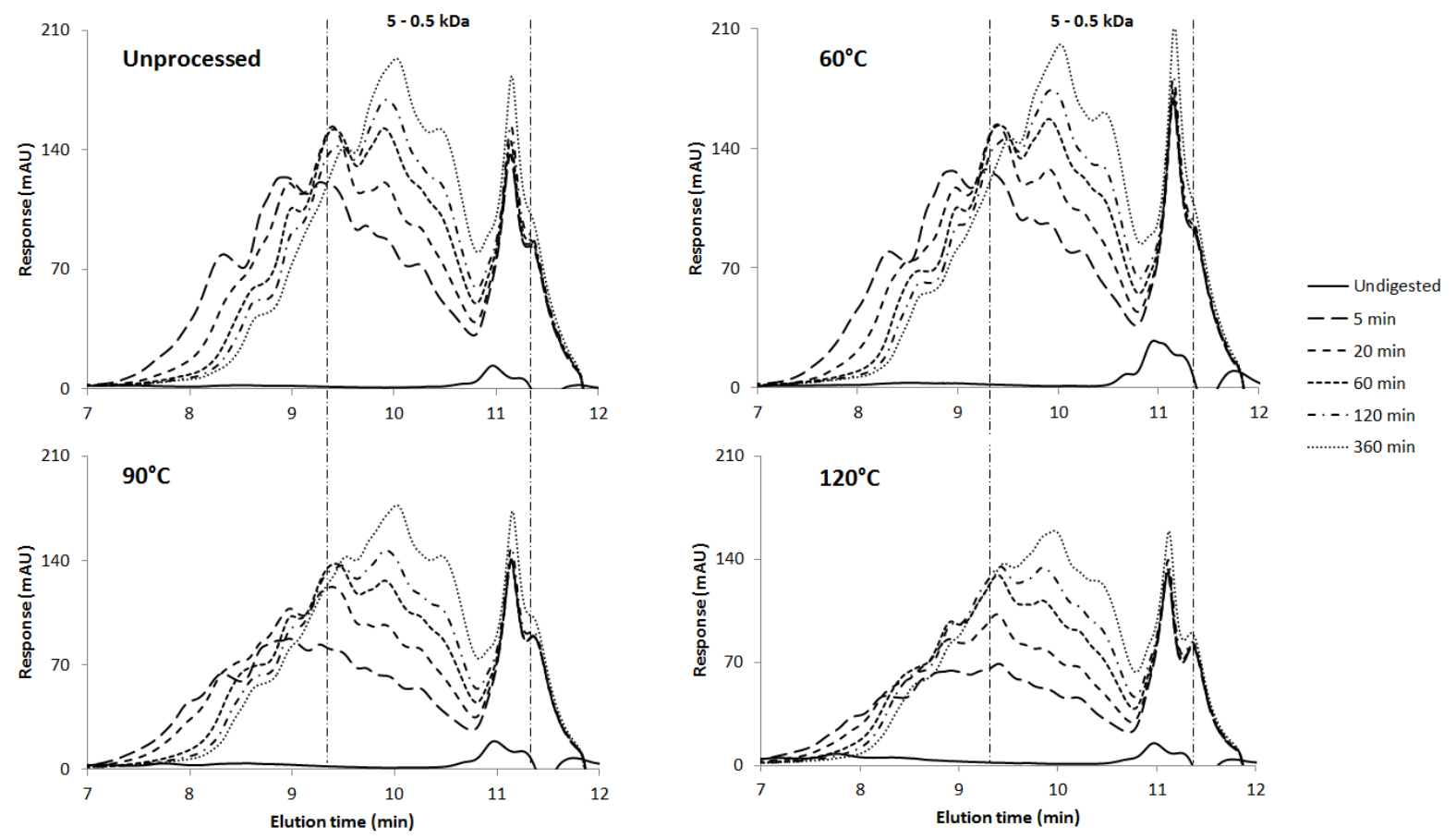

Figure A3.7. HPLC chromatograms of 5\% w/w suspensions of QPI E8 processed at different temperatures and subsequently digested for different time periods. Size exclusion chromatography is used for separation. This mean that larger peptides have a low elution time.
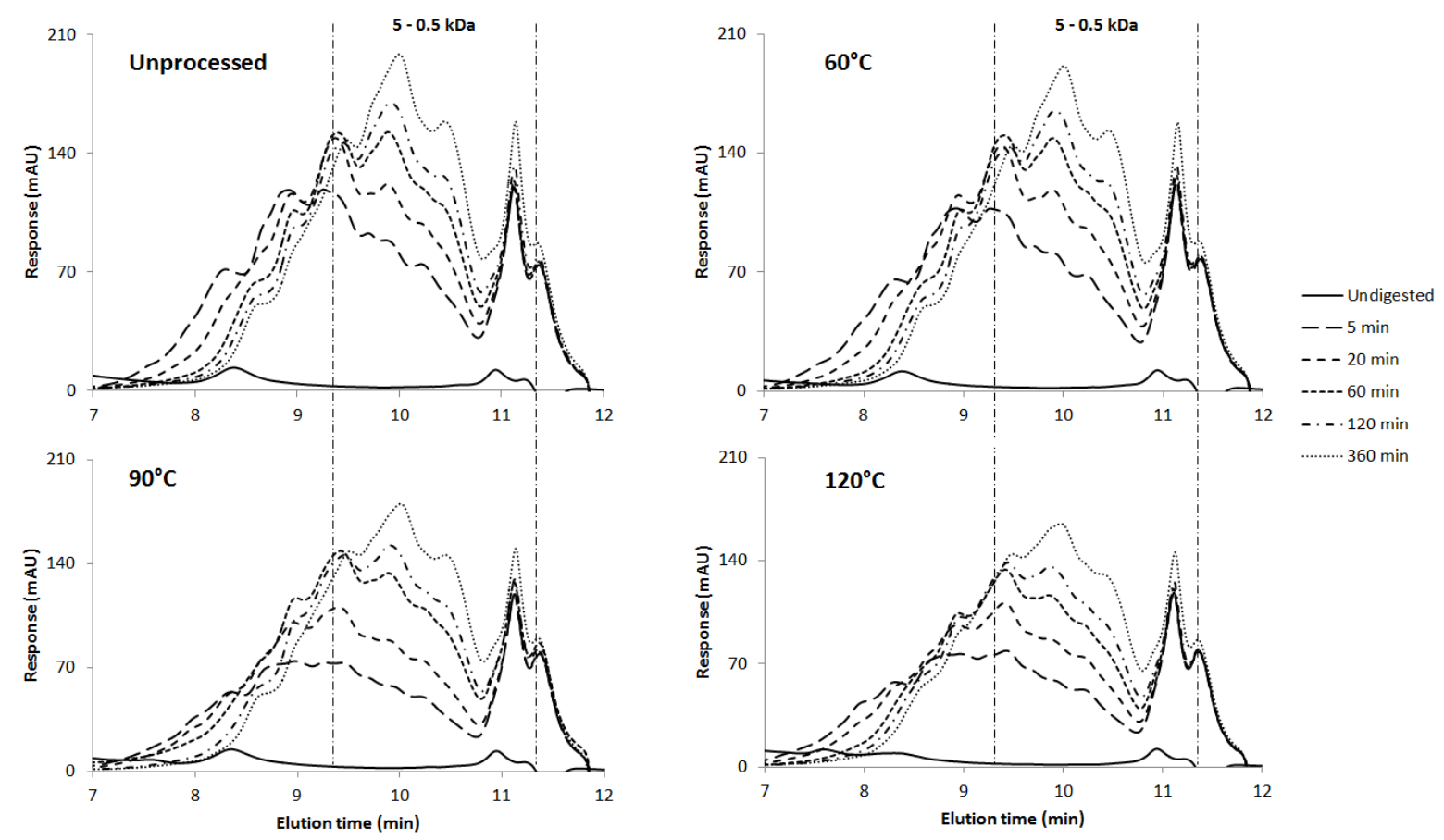

Figure A3.8. HPLC chromatograms of 5\% w/w suspensions of QPI E10 processed at different temperatures and subsequently digested for different time periods. Size exclusion chromatography is used for separation. This mean that larger peptides have a low elution time. 
Chapter 3
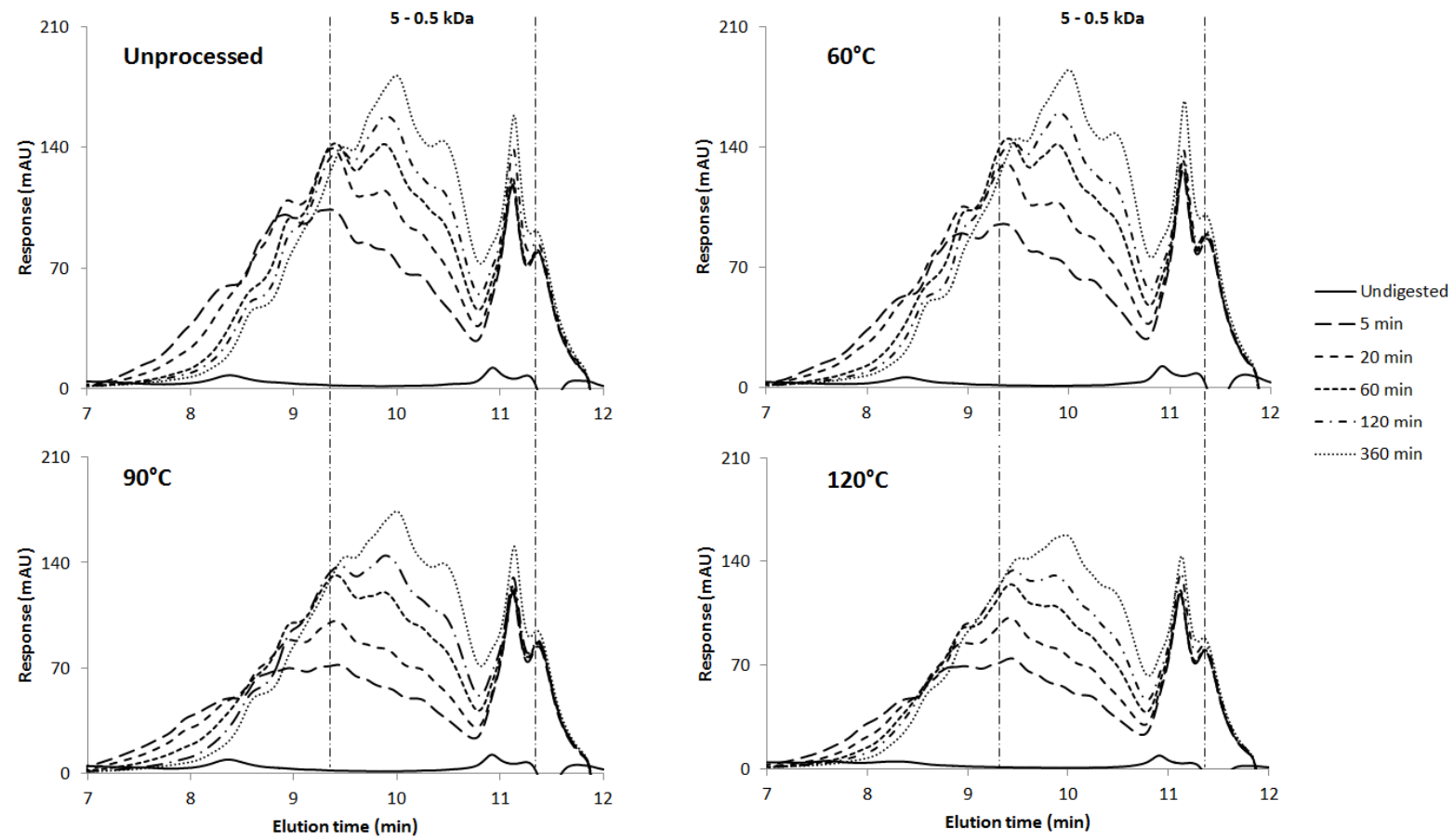

Figure A3.9. HPLC chromatograms of 5\% w/w suspensions of QPI E11 processed at different temperatures and subsequently digested for different time periods. Size exclusion chromatography is used for separation. This mean that larger peptides have a low elution time. 


\section{Chapter 4}

The effect of gel microstructure on simulated gastric digestion of protein gels

This chapter has been published as: Opazo-Navarrete, M., Altenburg, M., Boom, R.M., Janssen, A.E.M. (2017). The effect of microstructure on simulated gastric digestion of protein gels. Food Biophysics, 13, 124-138. 


\subsection{Abstract}

The objective of this study was to analyse the impact of the gel structure obtained by different heat-induced temperatures on the in vitro gastric digestibility at $\mathrm{pH} 2$. To achieve this, gels were prepared from soy protein, pea protein, albumin from chicken egg white and whey protein isolate at varying temperatures $\left(90,120\right.$ and $\left.140{ }^{\circ} \mathrm{C}\right)$ for $30 \mathrm{~min}$. Gels were characterised prior to digestion via microstructure and SDS-PAGE analysis. Subsequently, the gastric digestion process was followed via the protein hydrolysis and HPSEC analysis up to $180 \mathrm{~min}$. Peptides of different sizes $(<5 \mathrm{kDa})$ were gradually formed during the digestion. Our results showed that gels induced at $140{ }^{\circ} \mathrm{C}$ were digested faster. The protein source and gelation temperature had great influence on the in vitro gastric protein digestibility. 


\subsection{Introduction}

Protein gels are widely used to provide structure in foods. Several proteins have the ability to form gels on heating with different structures, depending on the source and gelling conditions (Nyemb et al., 2016; Urbonaite et al., 2015; Munialo et al., 2015). Protein gels can be prepared by cross-linking flexible proteins (e.g. gelatine and keratin) and by using protein aggregates of low-structured proteins (e.g. casein) or globular proteins (e.g. ovalbumin, whey proteins and soy proteins) (Renkema, 2001).

Gelation often involves several reactions such as denaturation, dissociation-association, and aggregation. The kinetics of the reactions involved largely determine the type of structure formed (Hermansson, 1996). The denaturation unfolds a native protein such that functional groups (such as sulfhydryl groups or hydrophobic groups) become exposed. These exposed groups may then interact to form aggregates. When the protein concentration is high enough, aggregation leads to the formation of a gel. At lower concentrations, the aggregation leads to precipitation of isolated protein aggregates (Renkema, 2001; Wang \& Damodaran, 1991). Protein gelation changes their rate of digestion (Shand et al., 2007). Understanding this mechanism is important for the development of foods that control the rate of release of macronutrients and slow the rate of the stomach emptying, thus limiting the consumed amount of food (Norton et al., 2007). Generally, plant proteins are less digestible than animal proteins (Van Vliet et al., 2015), and the digestibility of their gels is probably also less than those of animal origin; however the gel structure will influence this as well. Soy and pea proteins are important food proteins in many-based food formulations (Chen \& Zhao, 2013; Pelgrom et al., 2013). In soy, the main proteins are glycinin and $\beta$-conglycinin. Glycinin, having a molecular mass of $180 \mathrm{kDa}$, denatures at around $90{ }^{\circ} \mathrm{C}$ at neutral $\mathrm{pH}$, while $\beta$-conglycinin, with a molecular weight between 150 and $200 \mathrm{kDa}$, denatures at $70{ }^{\circ} \mathrm{C}$ (Renkema, 2001). Pea protein consists of $90 \%$ of the globulins legumin, vicilin and convicilin and for $10 \%$ of the albumins PA1 and PA2 (Nutralys pea protein technical bulletin). The molecular weight of the globulins varies from $175 \mathrm{kDa}$ for vicilin to $385 \mathrm{kDa}$ for legumin (Nutralys pea protein technical bulletin), while the proteins denature around $85{ }^{\circ} \mathrm{C}$ (Arntfield \& Murray, 1981).

During the gelation of proteins, a three-dimensional network of polypeptides, that is able to enclose water, is formed. There are two different classes of proteins gels: cross-linked protein networks and globular protein gel. The cross-linked protein networks are formed by flexible proteins being partially denatured. On the other hand, the globular proteins during unfolding 
expose hydrophobic parts, which are situated in the middle of the protein before unfolding, which tend to form clusters.

Studies on the effect of gel structure on the protein digestibility of plant proteins are limited. The structure of soy protein gelled with different coagulants strongly influenced the protein bioaccessibility (Rui et al., 2016). Bornhorst et al. (2015) indicated that hardness is an important predictor of food disintegration during gastric digestion: semi-soft or soft foods disintegrate faster than solid foods; liquid foods pass quickly through the stomach whereas solid foods remain in the stomach for longer times (Guo et al., 2014). However, its relation to the digestion rate was not addressed.

The aim of this study is to investigate the impact of the protein source and microstructure obtained by different heat-induced temperatures on the in vitro gastric digestibility in a simulated gastric environment.

\subsection{Materials and methods}

\subsubsection{Materials}

Soy protein isolate (SUPRO® 500E IP) (SPI) with a protein content of $83.4 \%$ (w/dw) was purchased from Solae (St. Louis, Missouri, USA). Pea protein concentrate (NUTRALYS® F85G) (PPC) was acquired from Roquette (France) with a protein content of $75 \%$ (w/dw). Whey protein isolate (WPI) (Bipro, lot no. JE 034-70-440-3) was supplied by Davisco Food International, Inc. (Le Sueur, USA) with a protein content of $99.3 \%$ (w/dw), while casein from bovine milk was supplied by FrieslandCampina (Wageningen, The Netherlands) with a protein content of $95.9 \%(w / d w)$. Albumin from chicken egg white (grade II) was purchased from Sigma-Aldrich (St. Louis, Missouri, USA) with a protein content of $92 \%$ (w/dw). The protein content of the sources was measured by Dumas analysis (Nitrogen analyser, FlashEA 1112 series, Thermo Scientific, Interscience, Breda, The Netherlands) in triplicate, using conversion factors of 5.71 for soy, 5.52 for pea, 6.25 for whey, 6.35 for casein and 6.45 for albumin from chicken egg white. Pepsin from porcine gastric mucosa (400 - 800 units/mg, P7125), mucin from the porcine stomach (Type III, M2378-100G) and all other chemicals were purchased from Sigma-Aldrich, Inc. (St. Louis, MO, U.S.A.). Milli-Q water $\left(18.2 \mathrm{M} \Omega \mathrm{cm}\right.$ at $25^{\circ} \mathrm{C}$, Millipore Corporation, Molsheim, France) was used for all experiments. 


\subsubsection{Preparation of gels}

\subsubsection{Soy and pea protein gels}

SPI and PPC protein dispersions were prepared by suspending SPI and PPC powder in Milli-Q water (20 g protein/100 g) and mixed with a spatula until it was completely wet. Subsequently, the mixture was left standing for $3 \mathrm{~h}$ at room temperature, to ensure further dissolution. Later, the mixture was put into PTFE tube (inner diameter $1 \mathrm{~cm}$ and length $10 \mathrm{~cm}$ ) with screw caps on both sides and then sealed. The tubes were rotated at $30 \mathrm{rpm}$ and heated at $90{ }^{\circ} \mathrm{C}$ in a water bath for $30 \mathrm{~min}$, while for the treatment at 120 and $140{ }^{\circ} \mathrm{C}$ heating was done in a glycerol bath for $30 \mathrm{~min}$. Subsequently, the tubes were immediately placed in ice water and stored overnight in the fridge $\left(4{ }^{\circ} \mathrm{C}\right)$. The next day the gels were carefully removed and analysed. The high temperatures were chosen considering some studies done with the same SPI source (Dekkers et al., 2018; Dekkers et al., 2016). While $90{ }^{\circ} \mathrm{C}$ was chosen considering the previous study about digestion of protein WPI and albumin from chicken egg white gels (Luo et al., 2015).

\subsubsection{Albumin from chicken egg white gel}

Albumin protein gel was prepared by mixing of albumin powder in Milli-Q water (20 $\mathrm{g}$ protein/100 g) and stirred at room temperature for $3 \mathrm{~h}$ until that was completely dissolved. The solution was covered with a Parafilm (Pechiney Plastic Packaging, Inc., IL, U.S.A.) to prevent evaporation during stirring. After dissolution, the tubes were put in a water bath at $90{ }^{\circ} \mathrm{C}$ and rotated at $30 \mathrm{rpm}$ for $30 \mathrm{~min}$. For the heating at 120 and $140{ }^{\circ} \mathrm{C}$, the heating was done in a glycerol bath for $30 \mathrm{~min}$. After heating, the tubes were immediately placed in ice water and stored overnight in the fridge $\left(4{ }^{\circ} \mathrm{C}\right)$. The next day the gels were carefully removed and analysed.

\subsubsection{Whey protein gel}

WPI powder was mixed with Milli-Q water $(20 \mathrm{~g}$ protein/100 $\mathrm{g})$ and stirred at room temperature for $3 \mathrm{~h}$ with a magnetic stirrer until the protein was completely dissolved. To prevent water evaporation, the solution was covered with Parafilm (Pechiney Plastic Packaging, Inc., IL, U.S.A.). After mixing, the solution was centrifuged (Thermo Scientific, MA, USA) at $3000 \mathrm{rpm}$ for 20 minutes at $20^{\circ} \mathrm{C}$ to remove air bubbles. Subsequently, the solution was put into the PTFE tube and heated the tubes were put in a water bath at $90{ }^{\circ} \mathrm{C}$ and rotated at $30 \mathrm{rpm}$ for $30 \mathrm{~min}$, while for the treatment at 120 and $140{ }^{\circ} \mathrm{C}$ heating was done in a glycerol bath for $30 \mathrm{~min}$. After 
heating, the tubes were immediately placed in ice water and stored overnight in the fridge (4 $\left.{ }^{\circ} \mathrm{C}\right)$. The next day the gels were carefully removed and analysed.

\subsubsection{Scanning electron microscopy (SEM)}

The gels were first dehydrated. Pieces were cut $(1 \times 1 \times 0.5 \mathrm{~cm})$ and fixed with $2.5 \mathrm{~mL} / 100 \mathrm{~mL}$ glutaraldehyde in $0.1 \mathrm{~mol} / \mathrm{L}$ phosphate buffer $(\mathrm{pH} 7.3)$ at room temperature. The samples were then rinsed with $0.1 \mathrm{~mol} / \mathrm{L}$ phosphate buffer $(\mathrm{pH}$ 7.3) and dehydrated in a substitution series of $50,70,80$, and $90 \mathrm{~mL} / 100 \mathrm{~mL}$ ethanol, for $15 \mathrm{~min}$ in each solution followed by three times for 30 min in absolute ethanol. The samples were vacuum dried at room temperature and mounted in carbon tabs (SPI Supplies/Structure Probe Inc., West Chester, USA) to fix the samples on aluminium pin mounts (SPI Supplies/Structure Probe Inc., West Chester, USA) for SEM examination (Phenom G2 Pure, Phenom-World BV, Eindhoven, The Netherlands).

\subsubsection{Texture analysis}

Gels were cut into cylinders of $1 \mathrm{~cm}$ diameter and $1 \mathrm{~cm}$ height. Uniaxial single compression tests were performed at room temperature using a texture analyser with a $100 \mathrm{~N}$ load cell (type 5564, Instron, MA, USA) equipped with a $50 \mathrm{~mm}$ cylindrical probe. The probe travelled to 5 $\mathrm{mm}$ distance to the tray at a speed of $5 \mathrm{~mm} / \mathrm{min}$. During the test run, the resistance of the sample was recorded for every $0.01 \mathrm{~s}$ and plotted as the absolute force $(\mathrm{N})$ versus time (s). The gel hardness was defined as the maximum peak force attained during the compression. Five cylinders were measured for each protein gel type.

\subsubsection{SDS-PAGE}

The molecular characterisation of the gels was done by reducing SDS polyacrylamide gel electrophoresis. Before electrophoresis, the protein gels were cut into small pieces. The samples were then diluted with sample buffer (0.5 M Tris-HCl, $\mathrm{pH} 6.8 ; 2 \%$ v/v SDS; $2.5 \%$ v/v glycerol; $0.2 \% \mathrm{v} / \mathrm{v}$ bromophenol blue; $0.5 \% \mathrm{v} / \mathrm{v} 2$-mercaptoethanol). The weight ratio of sample-tobuffer was 1:1. Each sample was heated to $90{ }^{\circ} \mathrm{C}$ for $4 \mathrm{~min}$ in an Eppendorf thermomixer (Eppendorf AG, Hamburg, Germany). The samples were then centrifuged at 10,000 $g$ for 5 min. An amount of $12 \mu \mathrm{L}$ of each sample and molecular weight markers Precision Plus Protein All Blue Standards (Bio-Rad Laboratories Inc., Hercules, USA) were loaded on a $12 \%$ TrisHCl Mini-PROTEAN TGX Precast Gel (Bio-Rad Laboratories Inc., USA). The electrophoresis was carried out at $200 \mathrm{~V}$ for about $1 \mathrm{~h}$. Afterwards, the gel was stained with Bio-safe Coomassie 
Stain (Bio-Rad Laboratories Inc., USA) and gel images were taken using a GS-900 Calibrated Densitometry System (Bio-Rad Laboratories, Inc., USA).

\subsubsection{Preparation of protein solutions}

Solutions were prepared by dissolving a mass equivalent to $0.1 \mathrm{~g}$ of protein from all different protein sources into $2 \mathrm{~mL}$ Eppendorf tube with Milli-Q water. The protein mixtures were stirred at room temperature for $30 \mathrm{~min}$ at room temperature and used for gastric digestion.

\subsubsection{In vitro gastric digestion of protein gels and solutions}

Simulated gastric juice (SGJ) was prepared according to Avila et al. (2016) with some modifications. Pepsin $(1 \mathrm{~g} / \mathrm{L})$ and mucin $(1.5 \mathrm{~g} / \mathrm{L})$ were dissolved in Milli-Q water and the $\mathrm{pH}$ was adjusted to 2.0 with $\mathrm{HCl}$. Additionally, some experiments were performed using $\mathrm{NaCl}$ $(8.775 \mathrm{~g} / \mathrm{L})$ to study the effect of salt on the enzyme activity. The simulated gastric digestion experiments were performed with $50 \mathrm{~mL}$ SGJ in a jacketed glass vessel connected to a water thermostat bath at $37{ }^{\circ} \mathrm{C}$ (Julabo GmbH, Seelbach, Germany) for $3 \mathrm{~h}$. Stirring was done at 100 rpm and the vessel was sealed with Parafilm (Pechiney Plastic Packaging, Inc., IL, U.S.A.) to avoid evaporation.

Based on the work of Jalabert-Molbes et al. (2007) on different kind of foods, cylindrical samples were cut ( $3 \mathrm{~mm}$ diameter $\mathrm{x} 3 \mathrm{~mm}$ height approximately) of each protein source with a puncher. Using these cylinders, a certain mass equivalent to $0.1 \mathrm{~g}$ of net protein was digested in $50 \mathrm{~mL}$ SGF, while for solution experiments, $0.1 \mathrm{~g}$ of protein in $2 \mathrm{~mL}$ Milli-Q water was digested in $50 \mathrm{~mL}$ SGF.

Samples were taken at 20, 60, 120 and $180 \mathrm{~min}$ for further analyses. Immediately after sampling, the samples were heated in a pre-heated Eppendorf thermomixer (Eppendorf AG, Hamburg, Germany) at $90{ }^{\circ} \mathrm{C}$ and 1,400 rpm for $5 \mathrm{~min}$ to inactivate the pepsin, which is rapidly inactivated at a temperature above $62{ }^{\circ} \mathrm{C}$ (Casey \& Laidler, 1951). All digestion experiments were done in triplicate.

\subsubsection{Size exclusion chromatography (HPSEC)}

The composition of the SGF during and after in vitro gastric digestion was analyzed via highperformance size-exclusion chromatography (HPSEC) using an Ultimate 3000 UHPLC system (Thermo Scientific, MA, U.S.A.) equipped with a TSKgel G3000SWxl column (7.8 mm x 300 mm) (Tosoh Bioscience LLC, King of Prussia, PA, U.S.A.) and TSKgel G2000SWxl (7.8 mm 
x $300 \mathrm{~mm}$ ) (Tosoh Bioscience LLC, King of Prussia, PA, U.S.A.) connected in line. For this analysis, $10 \mu \mathrm{L}$ of undiluted sample was used. The mobile phase was acetonitrile (30\%) in Milli-Q water $(70 \%)$ buffer containing trifluoroacetic acid $(0.1 \%)$. The flow rate was 1.5 $\mathrm{mL} / \mathrm{min}$ and the UV detector was set at $214 \mathrm{~nm}$. Calibration was done with thyroglobulin (670 $\mathrm{kDa})$, g-globulin (158 kDa), ovalbumin (44.3 kDa), $\alpha$-lactalbumin (14.1 kDa), aprotinin (6.51 $\mathrm{kDa})$, insulin $(5.7 \mathrm{kDa})$, bacitracin $(1.42 \mathrm{kDa})$ and phenylalanine (165 Da) (Sigma-Aldrich, Inc., St. Louis, MO, U.S.A.). The molecular mass was estimated based on the elution time of the molecular weights markers. All measurements were done in duplicate.

\subsubsection{Degree of hydrolysis (DH)}

The free amino groups $(\mathrm{mM})$ were measured using the o-phthaldialdehyde (OPA) assay method in order to determine the degree of hydrolysis attained. The OPA reagent (100 mL) was prepared by dissolving $3.81 \mathrm{~g}$ sodium tetraborate decahydrate (Borax) and $0.1 \mathrm{~g}$ of SDS in 80 mL milli-Q water. $80 \mathrm{mg}$ of o-phthaldialdehyde, that was dissolved in $2 \mathrm{~mL}$ ethanol, was then added to the Borax-SDS solution together with $88 \mathrm{mg}$ of dithiothreitol (DTT). The solution was filled up to $100 \mathrm{~mL}$ with milli-Q water and filtered over a $0.45 \mu \mathrm{m}$ filter. This solution was stored in a bottle covered with aluminium foil because the OPA reagent is sensitive to light.

A standard curve was prepared using L-serine in a concentration range of $50-200 \mathrm{mg} / \mathrm{L}$. The OPA assay was carried out by the addition of $200 \mu \mathrm{L}$ of sample (or standard) to $1.5 \mathrm{~mL}$ of OPA reagent. The absorbance of these solutions was measured after $3 \mathrm{~min}$ at $340 \mathrm{~nm}$ with a spectrophotometer DU 720 (Beckman Coulter Inc. Pasadena, CA, U.S.A). Free amino groups were expressed as serine amino equivalents $\left(\right.$ Serine $\mathrm{NH}_{2}$ ). The $\mathrm{DH}$ was calculated with the following equations:

$D H=\frac{h}{h_{t o t}} \cdot 100 \%$

$h=\frac{\left(\text { Serine } \mathrm{NH}_{2}-\beta\right)}{\alpha}$

Where $\alpha, \beta$, and $h_{\text {tot }}$ values reported by Adler-Nissen (1986) are used here (Table 4.1). All measurements were done in triplicate. 
Table 4.1. Value of constants $\alpha, \beta$ and $h_{\text {tot }}$ for different protein sources (Adler-Nissen, 1986).

\begin{tabular}{cccc}
\hline Protein & $\alpha$ & $\beta$ & $h_{\text {tot }}(\mathrm{meqv} / \mathrm{L})$ \\
\hline Soy & 0.970 & 0.342 & 7.8 \\
Pea & 1.00 & 0.40 & 7.4 \\
Casein & 1.039 & 0.383 & 8.2 \\
Whey & 1.00 & 0.40 & 8.8 \\
Albumin & 1.00 & 0.40 & 9.0 \\
\hline
\end{tabular}

\subsubsection{Statistical analysis}

Significance testing was performed using Fisher's least significant difference (LSD) test, and the differences were taken to be statistically significant when the p-value was $<0.05$. The multiple range test (MRT) included in the statistical program was used to prove the existence of homogeneous groups within each of the parameters analysed. The analysis was performed using Statgraphics Centurion XVI Statistical Software (Statistical Graphics Corp., Herdon, USA).

\subsection{Results and discussions}

\subsubsection{Gel characterization}

\subsubsection{SDS-PAGE analysis of gels}

As the electrophoretic analyses of the gels in Figure 4.1 shows, the protein subunits of the soy protein (7S-globulins and 11S-globulins) gelled at $90{ }^{\circ} \mathrm{C}$ did not show any change, while those gelled at $120^{\circ} \mathrm{C}$ exhibited faint bands of glycinin. The $7 \mathrm{~S}$ proteins (glycinin) could have formed large aggregates that were not able to penetrate the gel (Figure $4.1 \mathrm{~A}$ ). SPI gels made at $140{ }^{\circ} \mathrm{C}$ did not yield any bands anymore because of large protein-protein complexes, possibly covalently cross-linked, were formed that most likely were not able to dissolve in the sample buffer.

The protein banding pattern of pea proteins (Figure 4.1B) gelled at $90{ }^{\circ} \mathrm{C}$ were identical to the ungelled protein. Bands can be seen ranging from $\sim 100$ to $\sim 10 \mathrm{kDa}$ that originate mainly from legumin and vicilin, which are $11 \mathrm{~S}$ and $7 \mathrm{~S}$ globulins, respectively. Legumin, a hexameric protein, dissociates into two subunit peptides ( $\alpha$; acidic $38-40 \mathrm{kDa}$ and $\beta$; basic $19-22 \mathrm{kDa}$ ) when the S-S bonds are broken under reducing conditions (Shand et al., 2007; Crévieu et al., 1997). Vicilin is a trimeric protein, composed of three heterogeneous subunits of $\sim 50$ and convicilin $\sim 70 \mathrm{kDa}$. No S-S bonds are involved in the vicilin protein superstructure (Shand et 
al., 2007; O'kane et al., 2004). Gels made at $120^{\circ} \mathrm{C}$ still showed faint bands while gels made at $140{ }^{\circ} \mathrm{C}$ did not show any bands anymore. Both gels show some large protein-protein complexes, possibly covalently cross-linked, that were unable to penetrate the pores of the SDS PAGE gel.

Gels of animal proteins showed very similar behaviour. Albumin from chicken egg white (Figure 4.1C) gelled at $120{ }^{\circ} \mathrm{C}$ show that the ovomucin and ovotransferrin proteins bands gradually disappeared, and for gels made at $140{ }^{\circ} \mathrm{C}$ all bands had disappeared. The most abundant proteins in WPI are $\beta$-lactoglobulin and $\alpha$-lactalbumin (Figure 4.1D). With the increase of the temperature, the change in the intensity of serum albumin, $\beta$-lactoglobulin and $\alpha$-lactalbumin bands is shown. Also here, all bands were gone for gels made at $140{ }^{\circ} \mathrm{C}$. There is no evidence that heating for $30 \mathrm{~min}$ at $140{ }^{\circ} \mathrm{C}$ or at the other temperatures could cause hydrolysis of peptide bonds (Figure A4.1). To evaluate this, gels were ground and dissolved overnight in a solvent consisting of $8 \mathrm{~mol} / \mathrm{L}$ urea and $0.03 \mathrm{~mol} / \mathrm{L}$ dithiothreitol (DTT). The dissolved gels were then analyzed by HPSEC. The chromatograms showed that gels formed at different temperatures presented practically the same curves from elution time of $15 \mathrm{~min}$, which is equivalent at a molecular weight (MW) of $153 \mathrm{Da}$. Therefore, the temperatures and heating time used do not cause hydrolysis of peptide bonds. However, after heating at $140{ }^{\circ} \mathrm{C}$ is evident the protein aggregation after protein denaturation when hydrogen bonds and other interactions that stabilize its tertiary structure, are weakened causing the protein to unfold and subunits to dissociate. 
A

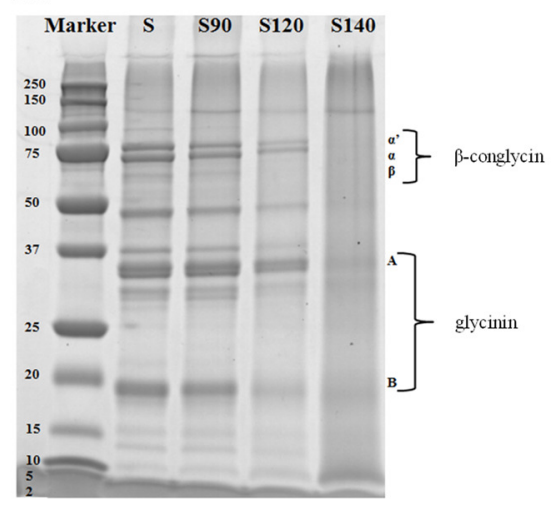

C

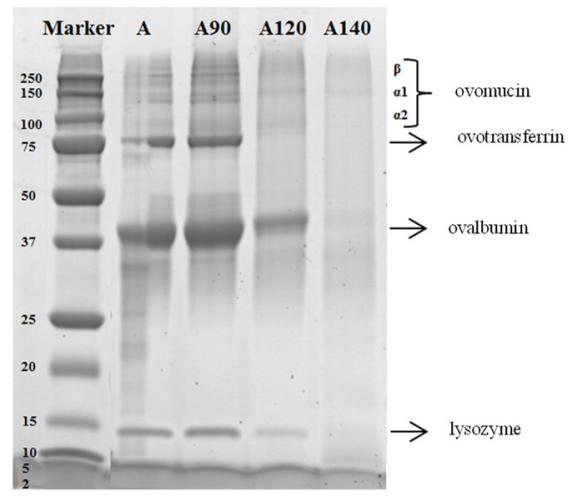

B

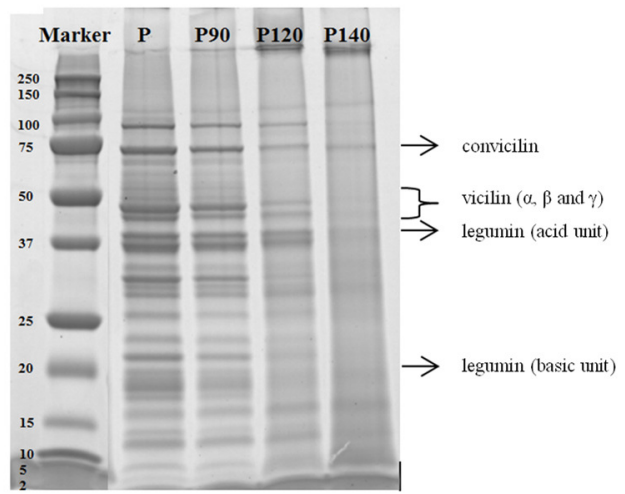

D

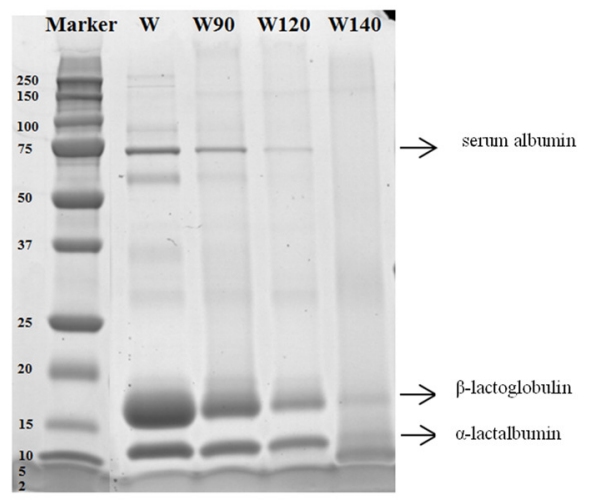

Figure 4.1 SDS-PAGE profiles of protein gels (A) S (soy protein isolate), S90 (soy protein gel made at $90{ }^{\circ} \mathrm{C}$ ), $\mathrm{S} 120$ (soy protein gel made at $120^{\circ} \mathrm{C}$ ), S140 (soy protein gel made at $140{ }^{\circ} \mathrm{C}$ ), (B) P (pea protein concentrate), P90 (pea protein gel made at $90{ }^{\circ} \mathrm{C}$ ), $\mathrm{P} 120$ (pea protein gel made at $120^{\circ} \mathrm{C}$ ), P140 (pea protein gel made at 140 ${ }^{\circ} \mathrm{C}$ ), (C) A (albumin from chicken egg white) A90 (albumin from chicken egg white protein gel made at $90{ }^{\circ} \mathrm{C}$ ), A120 (albumin from chicken egg white protein gel made at $120{ }^{\circ} \mathrm{C}$ ), A140 (albumin from chicken egg white protein gel made at $140{ }^{\circ} \mathrm{C}$ ) and (D) W (whey protein isolate), W90 (whey protein gel made at $90{ }^{\circ} \mathrm{C}$ ), W120 (whey protein gel made at $120^{\circ} \mathrm{C}$ ), $\mathrm{W} 140$ (whey protein gel made at $140{ }^{\circ} \mathrm{C}$ ).

\subsubsection{Gel morphology}

The microstructures of the four different protein types gelled at three different temperatures were examined using SEM (Figure 4.2). For the SPI gels, not structure differences were observed between the different gelling temperatures. The PPC gelled at $140{ }^{\circ} \mathrm{C}$ seems to present a more fragile structure than the PPC gelled at 90 and $120^{\circ} \mathrm{C}$. This fragility might result in a fast gel breakdown and thus faster protein digestion. Proteins from animal origin sources yield different structures. While WPI gelled at different temperatures did not show any change in morphology, albumin from chicken egg white gelled at $90{ }^{\circ} \mathrm{C}$ showed a more compact structure in comparison to the gels made at 120 and $140{ }^{\circ} \mathrm{C}$. This more compact structure might result in slower gel disintegration and therefore slower protein digestion. 


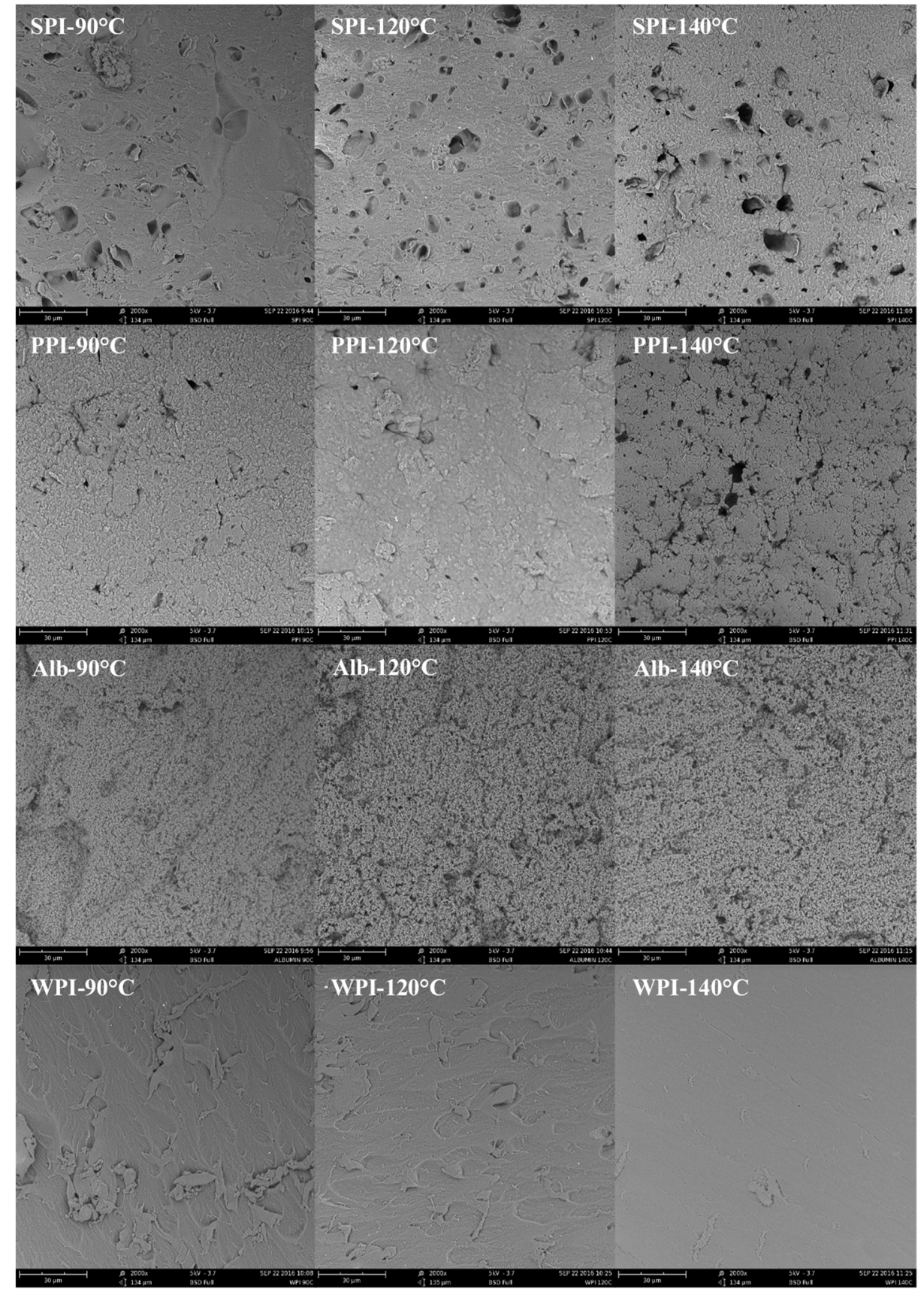

Figure 4.2. SEM images of protein gels made at different temperatures $\left(90,120\right.$ and $\left.140{ }^{\circ} \mathrm{C}\right)$ using different sources. SPI, soy protein isolate; PPI, pea protein isolate; Alb, albumin from chicken egg white; WPI, whey protein isolate.

Texture analysis was performed by measuring hardness where it was related to the peak force of the compression cycle. The hardness (N), shown in Figure 4.3, was different for all studied gels. WPI gelled at 90 and $120{ }^{\circ} \mathrm{C}$ presented significantly higher $(\mathrm{p}<0.05)$ hardness values of 27.4 and $38.6 \mathrm{~N}$, respectively, compared with to the other gels. In contrast, albumin from chicken egg white did not present significant differences $(\mathrm{p}>0.05)$ with any gelling temperature. For both plant protein gels, SPI and PPC, gelling at $140{ }^{\circ} \mathrm{C}$ resulted in the weakest gel, which could result in faster gel disintegration during digestion. 


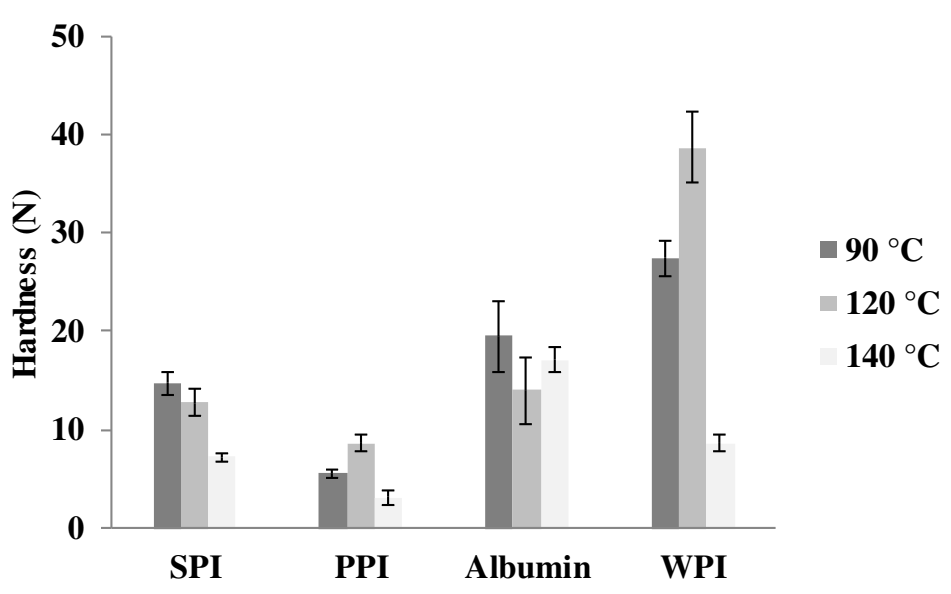

Figure 4.3. Hardness prior digestion of the different protein gels. SPI, soy protein isolate; PPC, pea protein concentrate; Albumin, albumin from chicken egg white; WPI, whey protein isolate.

As the physical integrity of gels depends on the balance between attractive and repulsive strengths of the protein molecules involved in the system (Hermansson, 1979). If the attractive strengths predominate, a coagulum is formed, and water is driven off the network matrix. If the repulsive strengths dominate, a three-dimensional network can not be formed (Kinsella, 1984).

The establishment of gel networks at 85 to $90{ }^{\circ} \mathrm{C}$ is attributed to the formation of covalent linkages, to the changes of the thiol group to disulphide linkages, and to hydrophobic interactions (Phillips et al., 1994). These interactions between nonpolar segments of adjacent polypeptides occur only if these polypeptides are opened, induced by heating. Cooling increases the hydrogen bonds.

However, heating at high temperatures could also result in progressively lower protein solubility and therefore hydrogen bonding is weakened. Furukawa et al. (1979) in a study on soy protein gels found that the gel hardness increased with heating temperature up to $80^{\circ} \mathrm{C}$, but the weakening occurred at higher temperatures, especially those greater than $110^{\circ} \mathrm{C}$. Based on processing temperature, they classified the gel as soft $\left(<50{ }^{\circ} \mathrm{C}\right)$, hard $\left(60\right.$ to $\left.110^{\circ} \mathrm{C}\right)$, and fragile $\left(>120{ }^{\circ} \mathrm{C}\right)$. This is in accordance with the results obtained on plant-based proteins in our research. The mechanism of gel formation was suggested to be cross-linking of soy proteins via disulfide and hydrogen bonding and hydrophobic interactions which controlled by temperature (Furukawa \& Ohta, 1982; Furukawa et al., 1979). However, the animal-based proteins (albumin and WPI) presented a different behaviour.

During heating, albumin is polymerized by intermolecular exchange linkages from sulphydrilic groups to disulphide linkages, which makes a network. Thermo-coagulation requires a balance 
of electrostatic attractions between protein molecules and hydrophobic interactions during the gel formation (Ma \& Holme, 1982). The intermolecular disulphide linkages increase the stability of the gel matrix. The increased size of polypeptide chains can delay the rupture of non-covalent interactions, and favour the gel network stability.

When whey protein solution is heated at a sufficiently high temperature $\left(75^{\circ} \mathrm{C}\right)$, the protein molecules unfold and interact to form intermediate aggregates prior to the formation of a gel network (Aguilera, 1995). The formation of intermediate aggregates involves two broad types of bonding: covalent and non-covalent bonding. The former consists of inter and intramolecular disulphide bonds (Grupta \& Reuter, 1992) formed via sulphydryl-disulphide interchange or sulphydryl oxidation reactions (Monahan et al., 1995). The latter are non-covalent interactions, such as hydrophobic, hydrogen bonding, ionic and other weak interactions that also contribute to the formation of aggregates and a gel network (McSwiney et al., 1994).

The non-covalent interactions, such as hydrophobic and 'Van der Waals' interactions, hydrogen bonds and ionic interactions, are related to the nature of the protein, to its concentration, to the solution $\mathrm{pH}$, to the denaturation intensity caused by heating and by the ionic medium (Schimidt, 1981), and interfere with the attractive and repulsive strengths of the three-dimensional network. Differences in gel-forming ability among globular proteins generally reflect the variety of degrees of protein-protein interactions and the number and extension of interactive sites available within the opened molecule (Phillips et al., 1994). Therefore, the differences in the gel hardness could be simply related to the nature of the protein source.

\subsubsection{Hydrolysis of protein gels}

Since many foods and meals contain significant amounts of salts, and it is known that this influences the behaviour of protein gels, the effect of $\mathrm{NaCl}$ on the rate of hydrolysis was studied. To assess this effect, we used 5\% SPI and PPC solutions in SGJ with and without $\mathrm{NaCl}$. In fact, SPI and PPC solutions digested in SGJ with and without $\mathrm{NaCl}$ did not show significant differences $(p>0.05)$ in the rates of hydrolysis (Figure A4.2). For this reason, further experiments were performed without $\mathrm{NaCl}$ added to the SGJ.

The in vitro gastric rate of hydrolysis of gels of SPI, PPC, albumin from chicken egg white and WPI was measured in time and is shown in Figures 4.4A, B, C and D, respectively. The hydrolysis profile of PPC (Figure 4.4B) and albumin from chicken egg white (Figure 4.4C) made at $140{ }^{\circ} \mathrm{C}$ increased rapidly in the first 60 min of digestion by pepsin, and then approached 
a plateau from 60 to 180 min. The SPI and WPI gels hydrolysed very slowly, more or less constantly during the full $180 \mathrm{~min}$ of digestion.
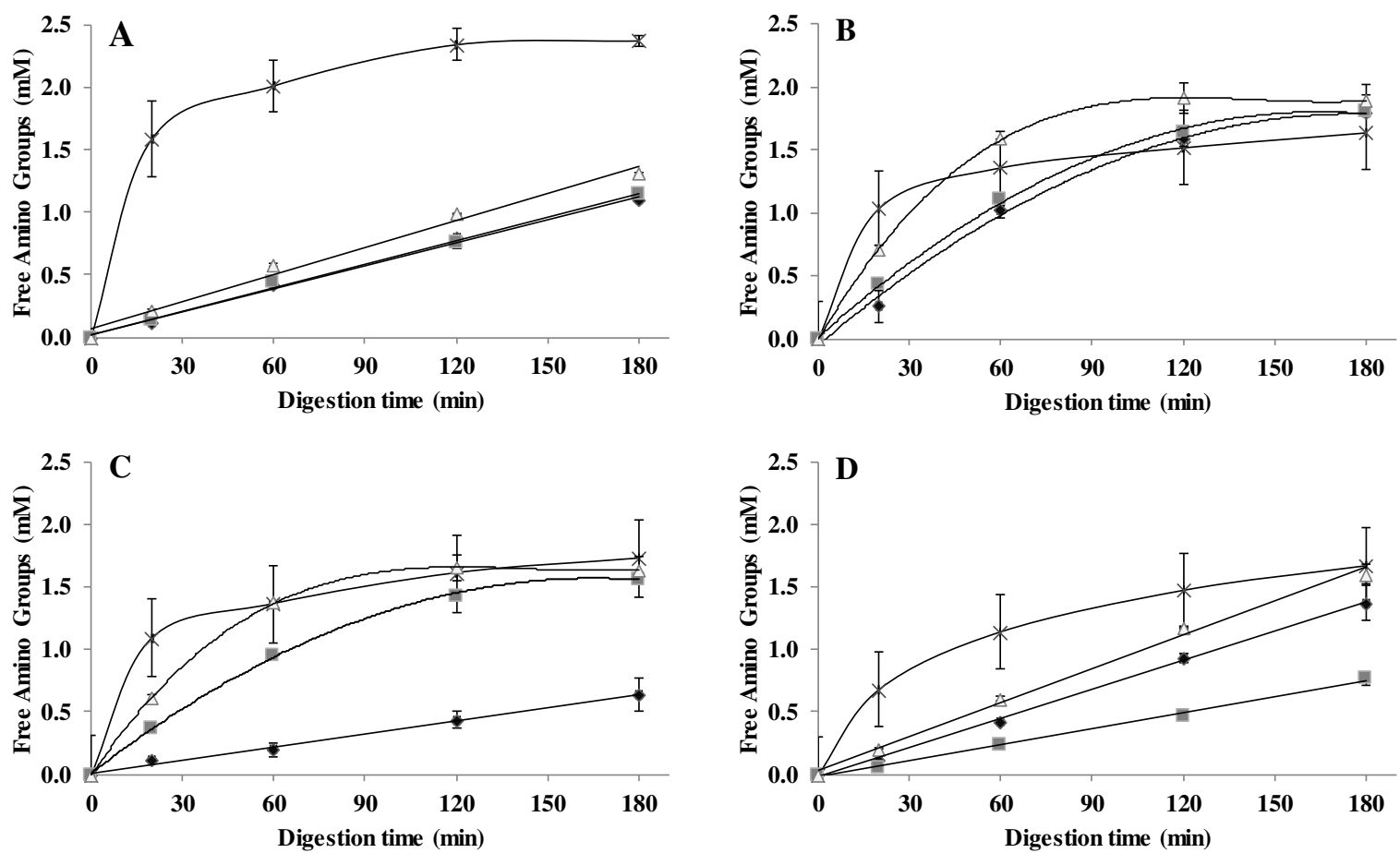

Figure 4.4. Hydrolysis profile of proteins solutions $(x)$ and proteins gelled at $90{ }^{\circ} \mathrm{C}(\diamond), 120{ }^{\circ} \mathrm{C}(\square)$ and $140{ }^{\circ} \mathrm{C}$ $(\triangle)$. (A) Soy protein gels, (B) pea protein gels, (C) albumin from chicken egg white gels and (D) whey protein gels.

The protein hydrolysis of the SPI gels (Figure 4.4A) made at $140{ }^{\circ} \mathrm{C}$ was somewhat, but significantly higher $(\mathrm{p}<0.05)$ than those made at lower temperatures. This may be related to their microstructure: the gel made at $140{ }^{\circ} \mathrm{C}$ appeared more porous (Figure 4.2). Along with this, the lower hardness of the gels made at $140{ }^{\circ} \mathrm{C}$ (Figure 4.3) is consistent with faster disintegration. Similar results were found with soft agar gel beads which disintegrated quickly in the human stomach whereas harder beads were broken down more slowly (Marciani et al., 2001). The same was observed with soft whey protein emulsion gels (Guo et al., 2015). Our PPC gels presented a significantly higher $(\mathrm{p}<0.05)$ protein hydrolysis after $180 \mathrm{~min}$ of digestion than the gels from other proteins (Figure 4.4B). The PPC gels made at $140{ }^{\circ} \mathrm{C}$ presented the fastest initial protein hydrolysis, however, after $180 \mathrm{~min}$ of digestion, all PPC gels converged to the same hydrolysis values ( $>00.05$ ). The PPC gels made at $140{ }^{\circ} \mathrm{C}$ showed a more fragile structure (Figure 4.2), which is consistent with their low hardness (Figure 4.3). We expect that these gels disintegrated quickly, and hence exposed a larger surface area for faster enzymatic initial hydrolysis. The final plateau $\mathrm{DH}$ value of around $7 \%$ is probably related to the type of peptide bonds available for hydrolysis. 
The digestion of the albumin from chicken egg white gels made at $90{ }^{\circ} \mathrm{C}$ yielded a significantly slower $(\mathrm{p}<0.05)$ hydrolysis during $180 \mathrm{~min}$ of digestion (Figure $4.4 \mathrm{C}$ ), while the gels made at 120 and $140{ }^{\circ} \mathrm{C}$ showed much faster initial hydrolysis followed by convergence towards a plateau DH value of around 5\%. The SEM analysis (Figure 4.2) showed that the gels made at $90{ }^{\circ} \mathrm{C}$ had a more compact microstructure than the gels made at higher temperatures. The lower disintegration rate would explain the much slower hydrolysis. In this case, the hardness (Figure 4.3) is not correlated with the rate of hydrolysis. The hydrolysis of the WPI gels (Figure 4.4D) all followed a linear trend, with the WPI gels made at $140{ }^{\circ} \mathrm{C}$ giving significantly higher protein hydrolysis values $(\mathrm{p}<0.05)$ and DH value (around 5\%). Also here, the microstructure analysis (Figure 4.2) and hardness analysis (Figure 4.4) does not correlate with the rate of hydrolysis of these gels.

\subsubsection{Hydrolysis of protein solutions}

The hydrolysis of the different protein isolates in solution was also followed (Figures 4.4A, B, $\mathrm{C}$ and D). WPI in solution showed a significantly faster hydrolysis $(\mathrm{p}<0.05)$ than casein; the hydrolysis of the casein in solution was slow but almost constant in time. The digestion rate is normally used to categorised into "slow" and "fast" digestibility, based on the time-dependent rise in plasma amino acids after food intake. The concept of slow and fast proteins, based on the rate at which blood plasma levels of amino acids rise, was first described by Boirie et al. (1997). They indicated that after ingestion, the absorption peak of whey proteins occurs between $40 \mathrm{~min}$ and $2 \mathrm{~h}$ after ingestion, while the rise in plasma amino acids after casein intake continues for $7 \mathrm{~h}$. This different hydrolysis behaviour is related to the coagulation that casein undergoes under acidic gastric conditions, forming a protein network resulting in a reduced accessibility to gastric digestive enzymes and thus delayed gastric emptying. Native whey proteins stay in solution at the same $\mathrm{pH}$ and thus remain fully accessible to the gastric digestive enzymes (Lambers et al., 2013). Thus, whey protein is a reference fast protein and casein a reference slow protein. The other sources (SPI, PPC and albumin from chicken egg white) presented even faster hydrolysis in solution than WPI, especially in the first 20 minutes, so these proteins have fast digestibility as well. Albumin from chicken egg white in solution stands out for its significantly highest digestibility $(\mathrm{p}<0.05)$, which is in contrast to the rate of hydrolysis of its gels (Figure 4.4C).

In our experiments, the final level of hydrolysis for the SPI in solution was much higher than the values attained with a gel, but the slow hydrolysis rate of the gel is indicative of very slow 
mass transfer. In contrast, the PPC in solution attained a final DH of around 6\%, which is in the same range as obtained for the gel. We conclude that the PPC gels are more open and porous than the SPI gels, and therefore offer much better access for the enzyme to act upon the gel.

\subsubsection{Size-exclusion chromatography (HPSEC) analysis}

The simulated gastric fluid samples taken from the digestion of protein gels were analysed with HPSEC (Figures 4.5 - 4.8). Typically, small peptides ranging from 5 to $0.1 \mathrm{kDa}$ were released over time. There was no discernible difference between the chromatograms made with gels prepared at different temperatures (Figure 4.5). This is consistent with the small differences in the overall hydrolysis rates as shown in Figure 4.4A.

The PPC gels made at 90 and $120{ }^{\circ} \mathrm{C}$ (Figures 4.6A and B) yield very similar chromatograms, but gels made at $140{ }^{\circ} \mathrm{C}$ (Figure 4.6C) showed higher peaks for the first $60 \mathrm{~min}$, which is represented for a larger area under the peak in the chromatogram. This is consistent with its higher overall rate of hydrolysis. After $180 \mathrm{~min}$ of gastric digestion, all chromatograms showed the same peaks and area, which shows that after 180 minutes, not just the protein hydrolysis is the same, but also the same fragments were formed.

The albumin from chicken egg white gels chromatograms showed minor differences between the protein gels made at 120 and $140{ }^{\circ} \mathrm{C}$ (Figures. 4.7B and C), while protein gels made at 90 ${ }^{\circ} \mathrm{C}$ (Figure 4.7A) showed smaller peaks in the chromatograms. Indeed, the overall hydrolysis from these protein gels made at $90{ }^{\circ} \mathrm{C}$ was also much lower than the others (Figure 4.4C).

The HPLC chromatograms of WPI gels made at $90{ }^{\circ} \mathrm{C}$ (Figure 4.8A) are nearly identical to the chromatograms of gels made at $140{ }^{\circ} \mathrm{C}$ (Figure 4.8C), and again this agreed with the protein hydrolysis values (Figure 4.4D). Therefore, heating at 90 and $140{ }^{\circ} \mathrm{C}$ results in no significant differences in the hydrolysis rate and peptide profile. WPI gels made at $120{ }^{\circ} \mathrm{C}$ (Figure $4.8 \mathrm{~B}$ ), however, showed smaller peaks between 0.1 and $5 \mathrm{kDa}$. As a lower hydrolysis (Figure 4.5D) and higher hardness (Figure 4.3) were found, we interpret this as this a more coherent gel, which disintegrated more slowly. 


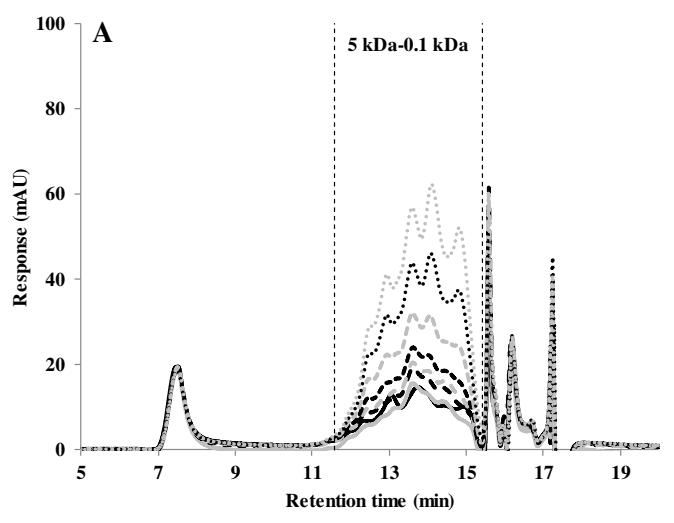

$$
\begin{aligned}
& - \text { Gastric juice } \\
& -5 \mathrm{~min} \\
& --10 \mathrm{~min} \\
& --20 \mathrm{~min} \\
& ---30 \mathrm{~min} \\
& --60 \mathrm{~min} \\
& \ldots . .120 \mathrm{~min} \\
& \ldots . .180 \mathrm{~min}
\end{aligned}
$$

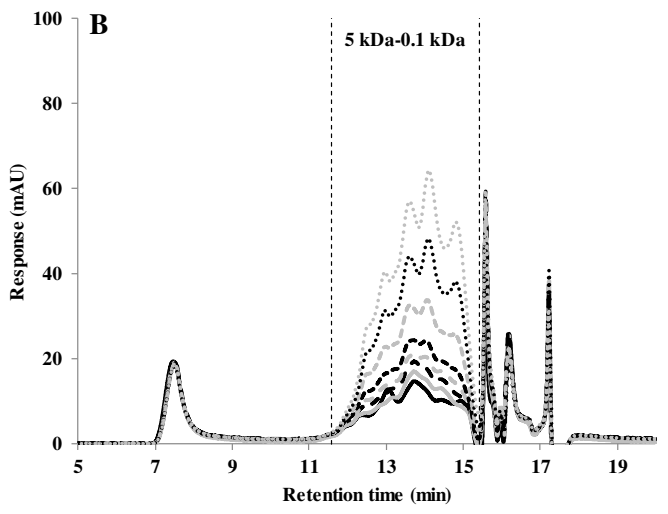

$$
\begin{aligned}
& - \text { Gastric juice } \\
& -5 \mathrm{~min} \\
& --10 \mathrm{~min} \\
& --20 \mathrm{~min} \\
& ---30 \mathrm{~min} \\
& --60 \mathrm{~min} \\
& \ldots \cdots 120 \mathrm{~min} \\
& \ldots . .180 \mathrm{~min}
\end{aligned}
$$

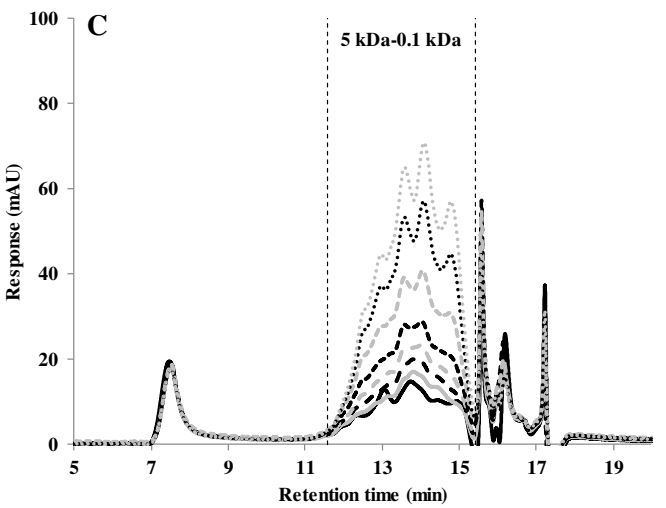

$$
\begin{aligned}
& - \text { Gastric juice } \\
& -5 \mathrm{~min} \\
& --10 \mathrm{~min} \\
& --20 \mathrm{~min} \\
& ---30 \mathrm{~min} \\
& ---60 \mathrm{~min} \\
& \cdots \cdots 120 \mathrm{~min} \\
& \cdots \cdots 180 \mathrm{~min}
\end{aligned}
$$

Figure 4.5. HPSEC profiles of gastric digestion of soy protein gels made at (A) $90{ }^{\circ} \mathrm{C}$, (B) $120{ }^{\circ} \mathrm{C}$ and (C) 140 ${ }^{\circ} \mathrm{C}$. 
The effect of microstructure on simulated gastric digestion of protein gels
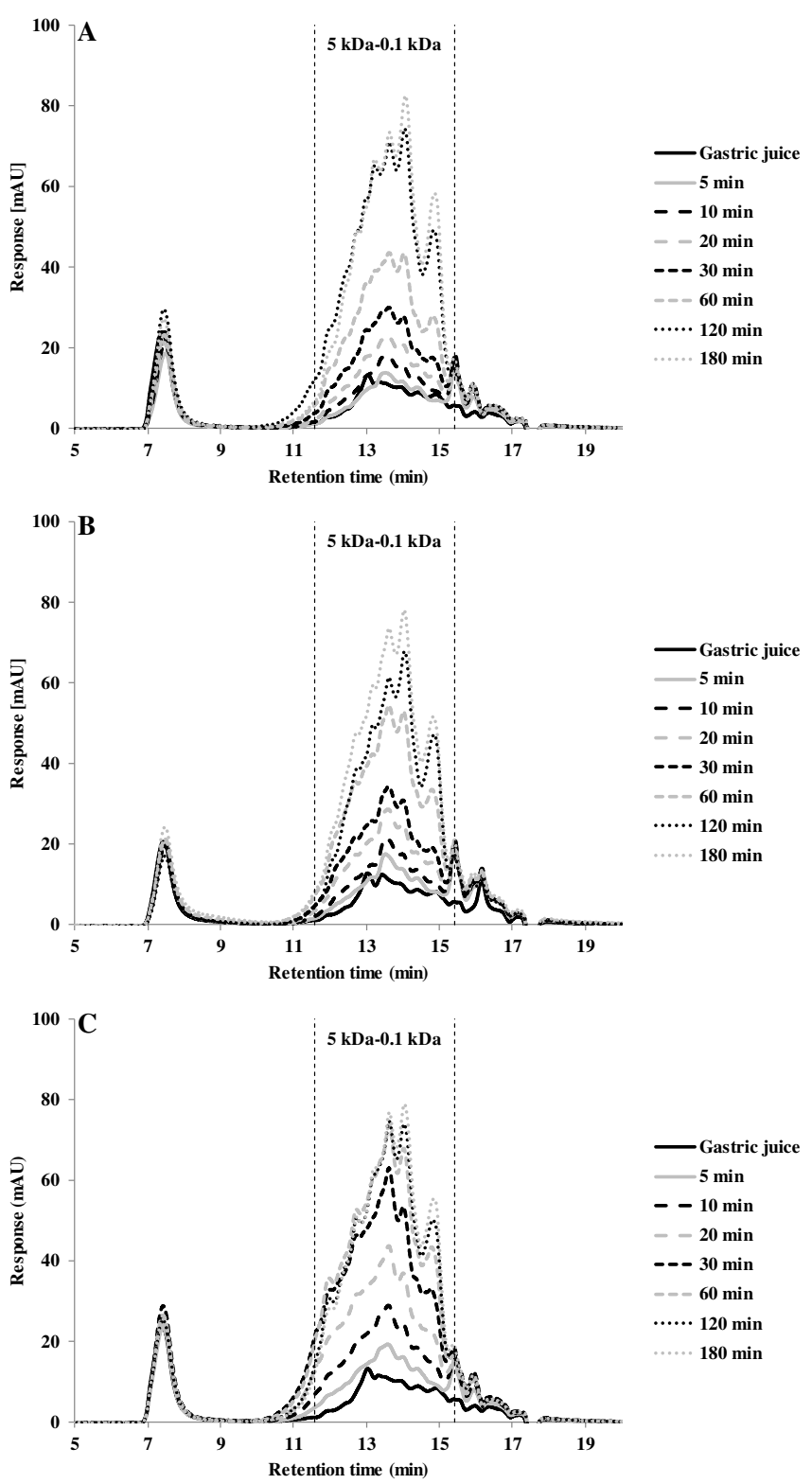

Figure 4.6. HPSEC profiles of gastric digestion of pea protein gels made at (A) $90{ }^{\circ} \mathrm{C}$, (B) $120{ }^{\circ} \mathrm{C}$ and (C) 140 ${ }^{\circ} \mathrm{C}$. 

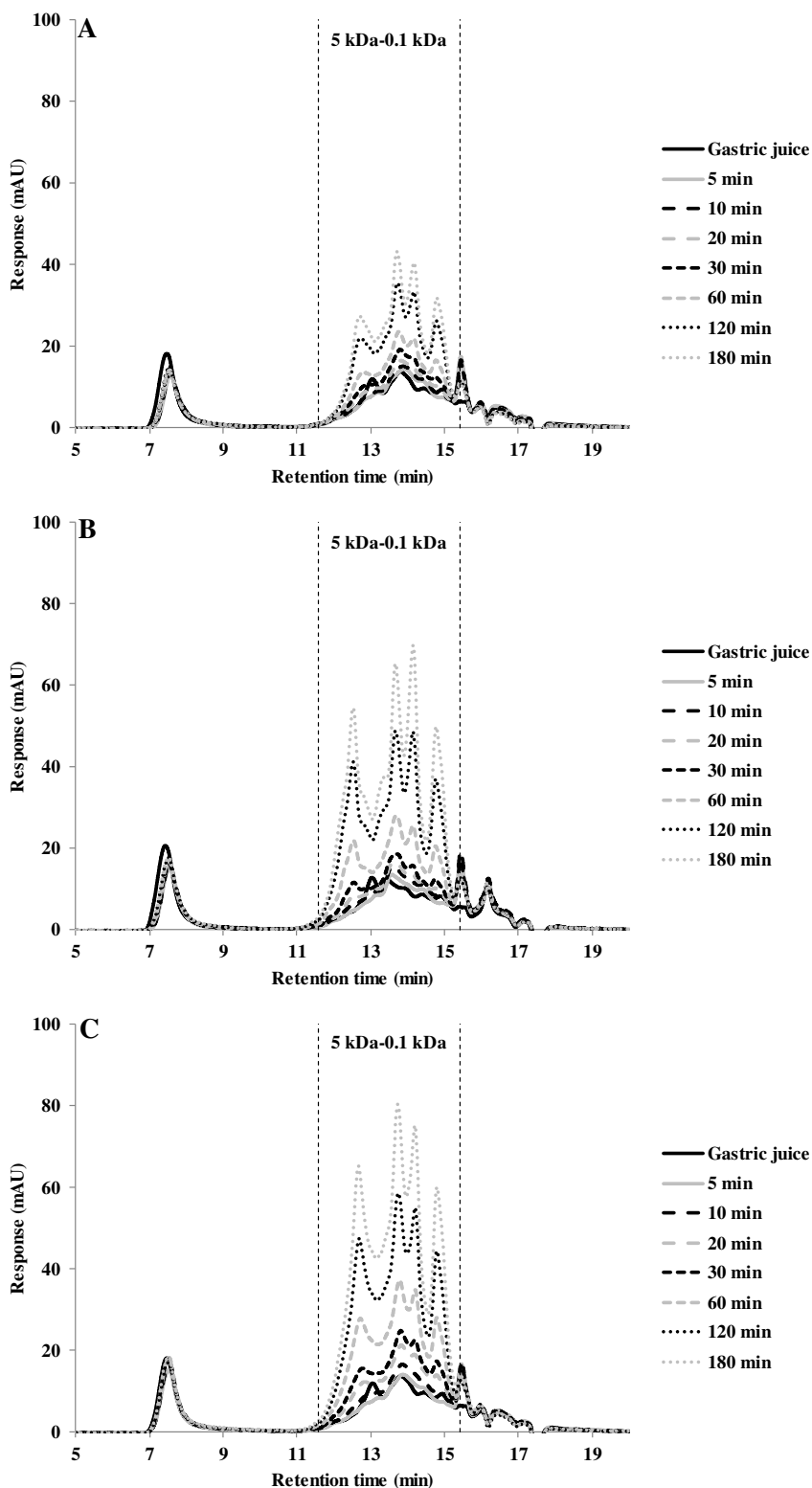

Figure 4.7. HPSEC profiles of gastric digestion of albumin from chicken egg white gels made at (A) $90{ }^{\circ} \mathrm{C}$, (B) $120^{\circ} \mathrm{C}$ and $(\mathrm{C}) 140{ }^{\circ} \mathrm{C}$. 

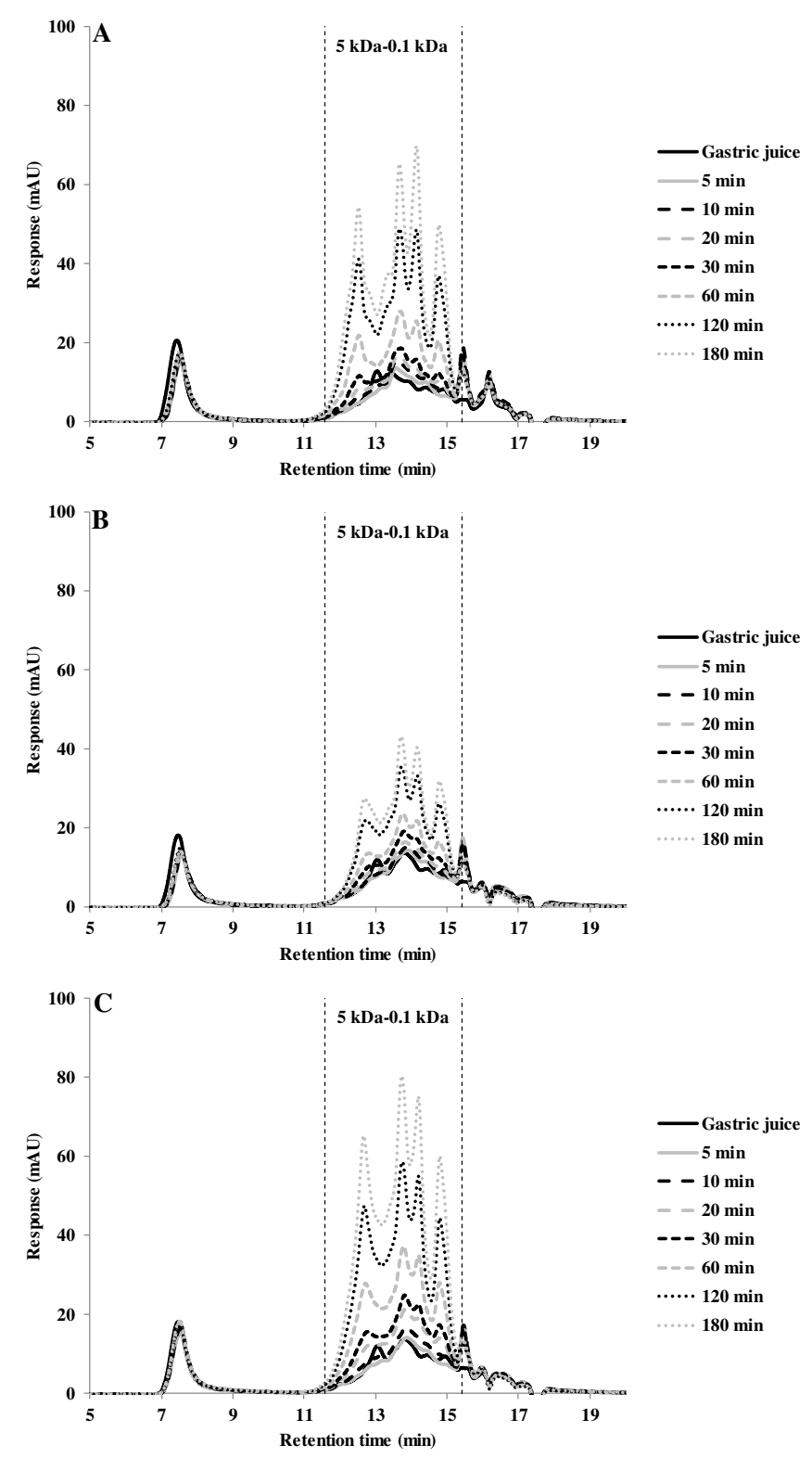

Figure 4.8. HPSEC profiles of gastric digestion of whey protein gels made at (A) $90{ }^{\circ} \mathrm{C}$, (B) $120{ }^{\circ} \mathrm{C}$ and (C) 140 ${ }^{\circ} \mathrm{C}$.

The HPSEC chromatograms of proteins in solution are shown in Figure 4.9. SPI, PPC, albumin from chicken egg white and WPI sources, but not casein, showed fast hydrolysis during the first $20 \mathrm{~min}$, which is also evident in the large number of peptides formed in the ranging from 5 to $0.1 \mathrm{kDa}$. The peptide peaks that are visible in the HPSEC chromatograms are overlapping with the peaks in Figures 4.5 - 4.9, indicating that the same peptides are cleaved off in gels and in solution. Also, larger peptide fragments are visible in the HPSEC chromatograms of proteins in solution. This is because all protein is present in solution, also large fragments. In the experiments with the gels, these large fragments most likely remained attached to the gel network. 

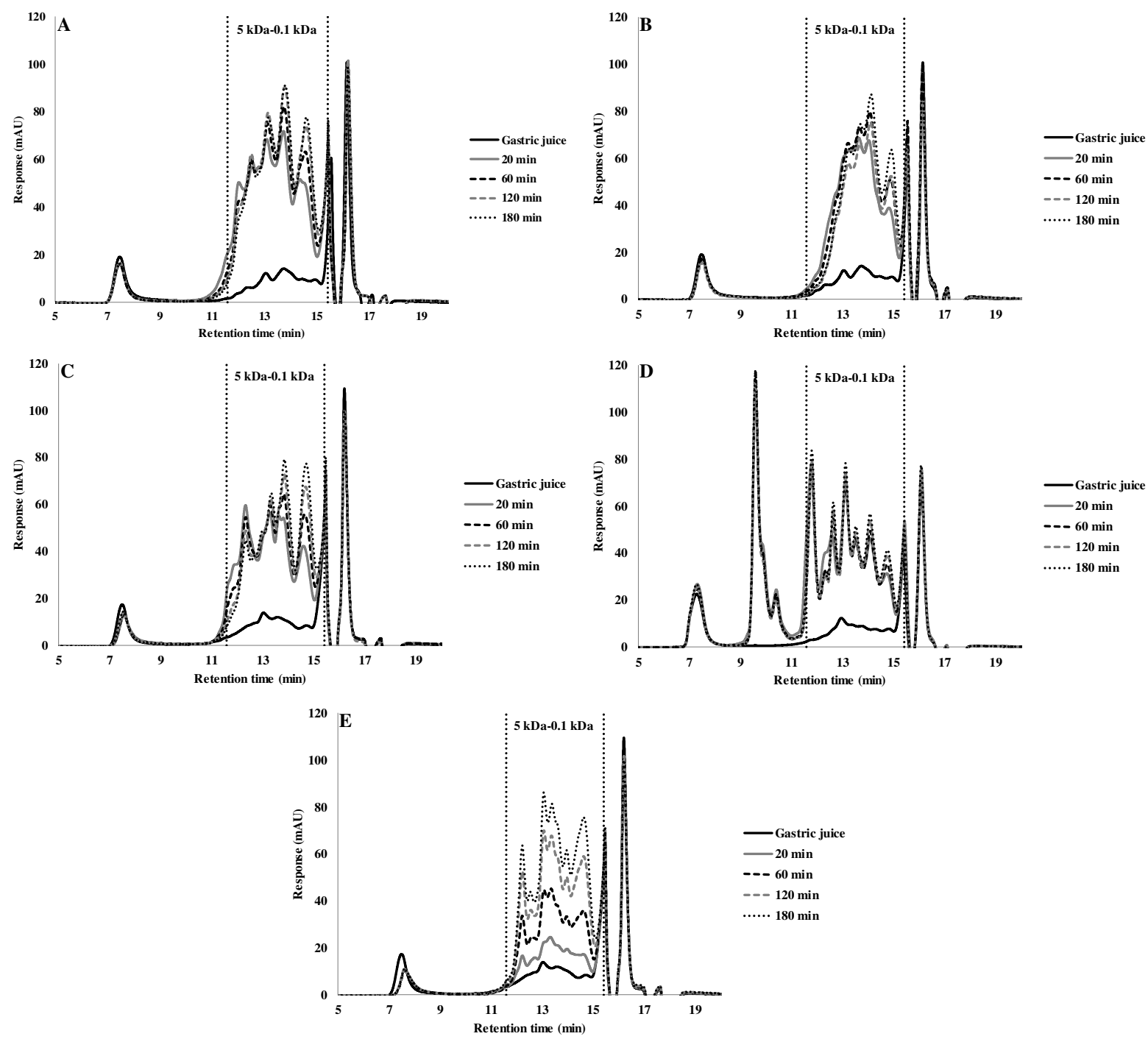

Figure 4.9. HPSEC profiles of gastric digestion of different protein sources in solution (5\% protein). (A) Soy protein isolate (SPI), (B) Pea protein isolate (PPI), (C) Albumin from chicken egg white, (D) Whey protein isolate (WPI) and (E) Casein.

The increase of the amount of smaller molecules $(\mathrm{MW}<5 \mathrm{kDa})$ also was found by Chen et al. (2013). They found as digestion time increased, larger molecules gradually shifted to smaller peptides as it was in this research. During proteolysis, the difference in the content of smaller peptide between samples gradually decreased. In SPI, $\beta$-conglycinin is more resistant to the proteolysis of pepsin than glycinin (Tsumura et al., 2004). Therefore, the peptides formed during digestion correspond to glycinin hydrolysis (Chen et al., 2013). 
The increased of smaller peptides during gastric digestion also was found by Laguna et al. (2017). Reduced SDS-PAGE showed that during gastric digestion the molecules smaller than $15 \mathrm{kDa}$ increased. This can be related to our results where a significant increase of peptides > $5 \mathrm{kDa}$ was found.

Luo et al. (2015) found that the peptide distribution for both albumin and WPI gels digested for $6 \mathrm{~h}$ showed that larger peptides $(10-2 \mathrm{kDa})$ decreased steadily afterwards due to progressing hydrolysis, while the small peptides below $2 \mathrm{kDa}$ increased throughout the whole process. An opposite result was found in our study, where peptides of different sizes $(5-0.1 \mathrm{kDa})$ increased due to progressing protein hydrolysis for both gels and protein solutions.

The presence of a large number of intermediate products suggests that the peptic hydrolysis of dissolved denatured protein gels follow the "zipper-type" according to Linderstrøm-Lang's theory (Luo et al., 2015).

\subsection{Conclusions}

The rate of in vitro gastric plant protein hydrolysis was assessed as a function of their state (gel, solution) and history (gelation temperature). SPI and PPC in solution are both fast proteins: they were hydrolysed quickly in the first $20 \mathrm{~min}$ and then attach a plateau degree of hydrolysis. SPI gel, however, was hydrolysed very slowly, while PPC gel was hydrolysed quickly. This correlates well with the mechanical strength and porosity of the gels and the SEM studies of the gel morphologies. For comparison, whey protein gelled at $90{ }^{\circ} \mathrm{C}$ was hydrolysed slowly, but WPI gels heated at 120 or $140{ }^{\circ} \mathrm{C}$ were fast hydrolysers. Albumin gels were hydrolysed slowly irrespective of their gelling temperature but still showed somewhat faster hydrolysis with higher gelation temperatures. It is thus clear that by adapting the gel morphology, one can also adapt the gastric digestibility of food products based on protein gelation, and that plantbased proteins show a range of digestibility that is related to the properties of the gels.

\subsection{References}

Adler-Nissen, J. (1986). Enzymic hydrolysis of food proteins (Elsevier Applied Science Publishers, New York), pp. 110-169.

Aguilera, J.M. (1995). Gelation whey proteins. Food Technology, 49(10), 83-89.

Arntfield, S.D., \& Murray, E.D. (1981). The Influence of Processing Parameters on Food Protein Functionality I. Differential Scanning Calorimetry as an Indicator of Protein 
Denaturation. Canadian Institute of Food Science and Technology Journal, 14(4), 289 294.

Avila, G., Opazo-Navarrete, M., Meurs, M., Minor, M., Sala, G., van Boekel, M., Stieger, M., \& Janssen, A.E.M. (2016). Denaturation and in Vitro Gastric Digestion of Heat-Treated Quinoa Protein Isolates Obtained at Various Extraction pH. Food Biophysics, 11, 184197.

Boirie, Y., Dangin, M., Gachon, P., Vasson, M.P., Maubois, J.L., \& Beaufrere, B. (1997). Slow and fast dietary proteins differently modulate postprandial protein accretion. Proceedings of the National Academy of Sciences, 94(26), 14930-14935.

Bornhorst, G.M., Ferrua, M.J., \& Singh, R.P. (2015). A Proposed Food Breakdown Classification System to Predict Food Behavior during Gastric Digestion. Journal of Food Science, 80, R924-R934.

Casey, B.E., \& Laidler, K.J. (1951). The kinetics and mechanism of the heat inactiviaton of pepsin. Journal of the American Chemical Society.73, 1455-1457.

Chen, N., Zhao, M., \& Sun, W. (2013). Effect of protein oxidation on the in vitro digestibility of soy protein isolate. Food Chemistry, 141(3), 3224-3229.

Chen, Q., Zhao, M., Sun, W. \& Zhao, M. (2013). Effects of malondialdehyde modification on the in vitro digestibility of soy protein isolate. Journal of Agricultural and Food Chemistry, 61(49), 12139-12145.

Crévieu, I., Carré, B., Chagneua, A.-M., Quillien, L., Guéguen, J., \& Bérot, S. (1997). Journal of Agricultural and Food Chemistry, 45(5), 1295-1300.

Dekkers, B.L., Hamoen, R., Boom, R.M., \& van der Goot, A.J. (2018). Understanding fiber formation in a concentrated soy protein isolate - Pectin blend. Journal of Food Engineering, 222, 84-92.

Dekkers, B.L., Nikiforidis, C.V., \& van der Goot, A.J. Shear-induced fibrous structure formation from a pectin/SPI blend. Innovative Food Science \& Emerging Technologies, 36, 193-200.

Furukawa, T., Ohta, S., \& Yamamoto, A. (1979). Texture-structure relationships in heat- 
induced soy protein gels. Journal of Texture Studies, 10, 333-346.

Furukawa, T., \& Ohta, S. (1982). Mechanical and water-holding properties of heat-induced soy protein gels as related to their structural aspects. Journal of Texture Studies, 13(1), 5969.

Guo, Q., Ye, A., Lad, M., Ferrua, M., Dalgleish, D., \& Singh, H. (2015). Disintegration kinetics of food gels during gastric digestion and its role on gastric emptying: an in vitro analysis. Food \& Function, 6, 756-764.

Guo, Q., Ye, A., Lad, M., Dalgleish, D., \& Singh, H. (2014). Effect of gel structure on the gastric digestion of whey protein emulsion gels. Soft Matter, 10, 1214-1223.

Gupta, V.K., \& Reuter, H. (1992). Protein solubility and gelation behavior of whey protein concentrates prepared by ultrafiltration of sweet cheese whey. Netherlands Milk and Dairy Journal, 46, 89-100.

Hermansson, A.-M. (1986). Soy protein gelation. Journal of the American Oil Chemists Society, 63(5), 658-666.

Hermansson, A.-M. (1979). Aggregation and denaturation involved in gel formation (SHERMAN, P. Food texture and rheology. New York: Academic Press), pp. 265.

Jalabert-Malbos, M.-L., Mishellany-Dutuor, A., Woda, A., \& Peyron, M.-A. (2007). Particle size distribution in the food bolus after mastication of natural foods. Food Quality and Preference, 18(5), 803-812.

Kinsella, J.E. (1984). Milk proteins: physicochemical and functional properties. Critical Reviews in Food Science and Nutrition, 21(3), 197-262.

Laguna, L., Picouet, P., Guardia, M.D., Renard, C.M.G.C., \& Sarkar, A. (2017). In vitro gastrointestinal digestion of pea protein isolate as a function of $\mathrm{pH}$, food matrices, autoclaving, high-pressure and re-heat treatments. LWT - Food Science Technology, $84,511-519$.

Lambers, T., van den Bosch, W., \& de Jong, S. (2013). Fast and slow proteins: modulation of the gastric behavior of whey and casein in vitro. Food Digestion, 4, 1-6. 
Luo, Q., Boom, R.M., Janssen, A.E.M. (2015). Digestion of protein and protein gels in simulated gastric environment. LWT-Food Science and Technology, 63(1), 161-168.

Ma, C.Y., \& Holme, J. (1982). Effect of chemical modification of some physical properties and heat coagulation of egg albumen. Journal of Food Science, 47, 1454-1459.

Marciani, L., Gowland, P.A., Spiller, R.C., Manoj, P., Moore, R.J., Young, P., \& Fillery-Travis, A.J. (2001). Effect of meal viscosity and nutrients on satiety, intragastric dilution, and emptying assessed by MRI. American Journal of Physiology-Gastrointestinal and Liver Physiology, 280(6), G1227-G1233.

McSwiney, M., Singh, H., \& Campanella, O.H. (1994). Thermal aggregation and gelation of bovine $\beta$-lactoglobulin. Food Hydrocolloids, 8, 441-453.

Monahan, F.J., German, J.B., \& Kinsella, J.E. (1995). Effect of pH and temperature on protein unfolding and thiol/disulfide interchange reactions during heat-induced gelation of whey proteins. Journal of Agricultural and Food Chemistry, 43(1), 46-52.

Munialo, C.D., van der Linden, E., Ako, K., \& de Jong, H.H.J. (2015). Quantitative analysis of the network structure that underlines the transitioning in mechanical responses of pea protein gels. Food Hydrocolloids, 49, 104-117.

Norton, I., Moore, S., \& Fryer, P. (2007). Understanding food structuring and breakdown: engineering approaches to obesity. Obesity Reviews, 8(1), 83-88.

Nyemb, K., Guérin-Dubiard, C., Pézenne, S., Jardin, J., Briard-Bion, V., Cauty, C., Rutherfurd, S., Dupont, D., \& Nau, F. (2016). The structural properties of egg white gels impact the extent of in vitro protein digestion and the nature of peptides generated. Food Hydrocolloids, 54, 315-327.

O’Kane, F.E., Happe, R.P., Vereijken, J.M., Gruppen, H., van Boekel, M.A.J.S. (2004). Characterization of Pea Vicilin. 1. Denoting Convicilin as the $\alpha$-Subunit of the Pisum Vicilin Family. Journal of Agricultural and Food Chemistry, 52, 3141-3148.

Pelgrom, P.J.M., Vissers, A.M., Boom. R.M., \& Schutyser, M.A.I. (2013). Dry fractionation for production of functional pea protein concentrates. Food Research International, 53, 232-239. 
Phillips, L.G., Whitehead, D.M., \& Kinsella, J.E. (1994). Structure functionproperties of food proteins (San Diego: Academia Press), pp. 271.

Renkema, J.M.S. (2001). Formation, structure and rheological properties of soy protein gels. Ph.D. Thesis, Wageningen University, Wageningen, The Netherlands.

Rui, X., Fu, Y., Zhang, Q., Li, W., Zare, F., Chen, X., Jiang, M., \& Dong, M. (2016). A comparison study of bioaccessibility of soy protein gel induced by magnesiumchloride, glucono- $\delta$-lactone and microbial transglutaminase. LWT-Food Science and Technology, $71,234-242$.

Shand, P.J., Ya, H., Pietrasik, Z., \& Wanasundara, P.K.J.P.D. (2007). Physicochemical and textural properties of heat-induced pea protein isolate gels. Food Chemistry, 102(4), 1119-1130.

Schmidt, R.H. (1981). Gelation and coagulation (CHERRY, J.P., Protein functionality in foods, Washington: ACS), pp. 131-147.

Tsumura, T., Saito, T., Kugimiya, W., \& Inouye, K. (2004). Selective proteolysis of the Glycinin and $\beta$-Conglycinin fractions in a soy protein isolate by Pepsin and Papain with controlled pH and temperature. Journal of Food Science, 69(5), 363-367.

Urbonaite, V., de Jong, H.H.J., van der Linden, E., \& Pouvreau, I. (2015). Water holding of soy protein gels is set by coarseness, modulated by calcium binding, rather than gel stiffness. Food Hydrocolloids, 46, 103-111.

Van Vliet, S., Burd, N.A., \& van Loon, L.J. (2015). The Skeletal Muscle Anabolic Response to Plant- versus Animal-Based Protein Consumption. The Journal of Nutrition, 145, 1981-1991.

Wang, C.-H., \& Damodaran, S. (1991). Thermal gelation of globular proteins: influence of protein conformation on gel strength. Journal of Agricultural and Food Chemistry, 39(3), 433-438. 


\subsection{Appendix}
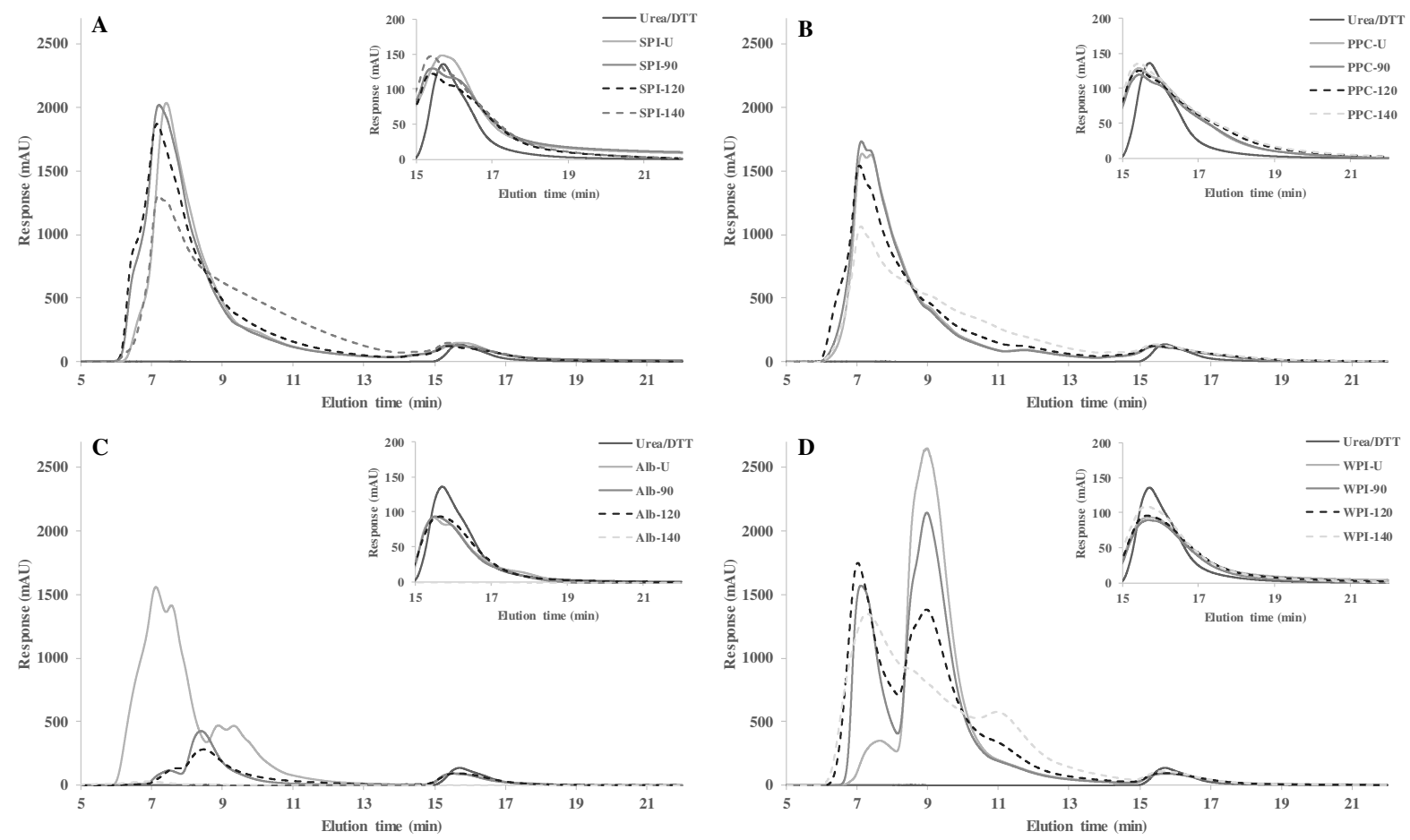

Figure A4.1 HPSEC profiles of protein solutions and protein gels made at different temperatures (90, 120 and 140 ${ }^{\circ} \mathrm{C}$ ) of (A) SPI (soy protein isolate), (B) PPC (pea protein concentrate), (C) Alb (albumin from chicken egg white) and (D) WPI (whey protein isolate).

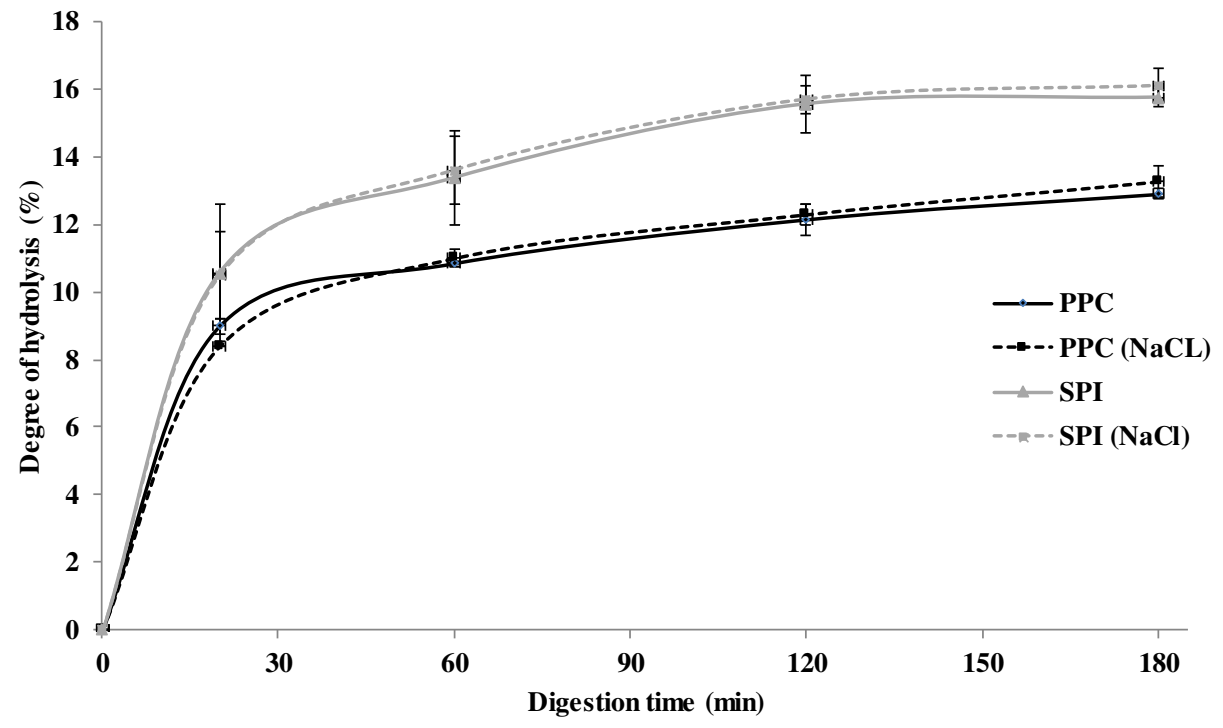

Figure A4.2 Degree of hydrolysis of pea protein concentrate (PPC) and soy protein isolate (SPI) with and without $\mathrm{NaCl}$ added to the simulated gastric juice. 


\section{Chapter 5}

Dry fractionation of quinoa sweet varieties Atlas and Riobamba for sustainable production of protein and starch fractions

This chapter has been published as: Opazo-Navarrete, M., Tagle, D., Boom, R.M., Janssen, A.E.M., Schutyser, M.A.I. Dry fractionation of quinoa sweet varieties Atlas and Riobamba for sustainable production of protein and starch fractions. Journal of Food Composition and Analysis, 74, 95-101. 


\subsection{Abstract}

Dry milling and subsequent sieving were evaluated as an alternative to the conventional wet extraction of quinoa (Chenopodium quinoa Willd.) proteins and starch. Specifically, quinoa sweet varieties have the potential to be dry fractionated. Dry fractionation of quinoa is an alternative and more sustainable route for producing protein-enriched and starch fractions than conventional wet fractionation. Quinoa seeds were subjected to coarse grinding and subsequently sieved using different sizes of sieves to obtain fractions enriched in protein and starch. The protein-enriched fractions contained $\sim 32 \%$ proteins $(32 \mathrm{~g} / 100 \mathrm{~g}$ dry solids) while the starch-rich fractions contained 86 - 89\% starch (86 - $89 \mathrm{~g} / 100 \mathrm{~g}$ dry solids). The quinoa fractions were characterised and compared to wet-isolated starch and protein. The gelatinization temperature of the starch-rich fraction was influenced by the residual presence of proteins. The starch-rich fraction also had different pasting properties than starch isolate. The unheated protein-enriched fractions showed high water retention capacity and solubility, which could be potentially interesting to apply in gluten-free products. 


\subsection{Introduction}

Growing global population leads to increasing demand for food, which results in growing environmental pressure. Therefore, we need much more efficient food production, which can be achieved by directly making food from plant-based proteins (Aiking, 2011). One such plantbased protein source is quinoa (Chenopodium quinoa Willd.), which is a pseudocereal native to South America. Due to the protein quality and quantity in the quinoa grain, which is often superior to those of more common cereal grains, the quinoa cultivation has expanded to many other continents, but grown amounts are still very low. The amino acid content, mainly the essential amino acids, the quinoa is considered well-balanced food for human nutrition. Also, quinoa overcomes cereals in the levels of dietary fibre,, phosphorus, magnesium and iron. In addition, the quinoa is a good source of calcium, which is useful for vegans and lactose intolerant people. Due to the gluten-free nature of quinoa is considered safe for celiac patients (Maradini et al., 2017).

Protein isolation and concentration of grains are generally done via a wet fractionation method. This method involves large amounts of water, chemicals and energy. Moreover, the conditions during wet fractionation are detrimental to the functionality of the individual components (e.g. protein) (Wang et al., 2014). Dry fractionation has major advantages compared to wet fractionation of foods due to its much lower energy consumption and retention of the native ingredient properties (Schutyser \& van der Goot, 2011), even though it generally gives lower purity fractions and thus should be considered a concentration method.

Most of the varieties of quinoa contain saponins, bitter tasting triterpenoid glycosides, which are concentrated in the seed coat and must be removed before consumption (Repo-Carrasco \& Serna, 2011). Quinoa saponins are commonly removed by washing the grains with water in the ratio of 1:8 (seeds:water) (Antunez, 1981). Sweet varieties of quinoa as Atlas and Riobamba, which are virtually free of saponins, have the potential to provide high-quality protein in a more sustainable way than bitter quinoa varieties (Avila et al., 2016) because they do not need additional post-harvest processing to remove the saponins.

The use of a protein-enriched flour as food ingredient depends both on the high-quality amino acid content, as well as on the functional properties of the proteins. These functional properties are correlated to the degree of unfolding of the protein isolates, which is affected by conventional wet extraction conditions (Abugoch et al., 2008), due to the exposure to low 
and/or high $\mathrm{pH}$ and the thermal load during dehydration of the fractions. Besides, wet fractionation excludes the insoluble proteins from the isolate, which are generally highly aggregated proteins with specific functionality (Pelgrom et al., 2013). Therefore, dry fractionation of quinoa seeds may be both more efficient and more able to retain the native functional and nutritional properties.

Dry fractionation of quinoa involves coarse milling during which the perisperm (internal body of the seed full of starch grains) is liberated from a surrounding embryo that breaks into small fragments. Previous studies did not characterize the composition of the fractions but only focused on the protein purity and digestibility (Opazo-Navarrete et al., 2017; Föste et al., 2015). Opazo-Navarrete et al. (2017) obtained a protein-enriched flour with a purity of around $28 \%$ (28 g/100 g dry matter) using a bitter variety. Föste et al. (2015) separated the bran of quinoa seed, after milling and sieving and obtained a protein purity of around 26\% (26 g/100 g dry matter).

Since starch is the major component of quinoa comprising approximately $55 \%$ of the seed, the possibility to concentrate or isolate this component represents an interesting challenge. Quinoa starch has unique properties such as a low pasting temperature and high freeze-thaw stability (Abugoch, 2009). Further, the small size of granules (about 1 to $3 \mu \mathrm{m}$ ) and their relatively low amylose content (11\%) (Li et al., 2016), generate interest in the food industry.

The aim of this study was to explore the feasibility of dry fractionation to obtain a proteinenriched flour and a starch concentrate from two quinoa sweet varieties (Atlas and Riobamba) and characterise these fractions.

\subsection{Materials and methods}

\subsubsection{Materials}

Quinoa sweet varieties Atlas and Riobamba were acquired from GreenFood50 (Wageningen, The Netherlands).

\subsubsection{Material preparation}

Quinoa seeds were pre-milled to separate the cotyledons from the seed with a lab scale mill (Fritsch Mill Pulverisette 14, Idar-Oberstein, Germany) with a $2 \mathrm{~mm}$ screen at room 
temperature. The rotor speed was $4000 \mathrm{~g}$ with a feed rate of $\sim 20 \mathrm{~g} / \mathrm{min}$. The milling experiments were done in triplicate.

The pre-milled quinoa seeds were sieved by air jet sieving (Alpine200 LS-N, HosokawaAlpine, Augsburg, Germany) with different sieves (0.800, 0.630 and $0.315 \mathrm{~mm})$ at $1500 \mathrm{~Pa}$ for $2.5 \mathrm{~min}$. During these sieving experiments each time a sample of $25 \mathrm{~g}$ of pre-milled seeds was sieved. The protein separation efficiency (PSE) was defined for each obtained fraction as the percentage of protein in the respective fraction compared to the protein in the raw material. All experiments were done in triplicate for each pre-milled quinoa seeds fraction.

In order to compare the protein-enriched flour and starch isolate fractions obtained by the dry fractionation method with its isolate, both protein and starch were isolated by wet fractionation method. Quinoa protein of the variety Riobamba was isolated according to the procedure described by Opazo-Navarrete et al. (2017). Starch was isolated from defatted quinoa flour (Riobamba) via the following steps. Defatted quinoa flour was dispersed in Milli-Q water and stirred for $2 \mathrm{~h}$ at $20{ }^{\circ} \mathrm{C}$. Subsequently, the quinoa flour dispersed in Milli-Q water was sieved using a 250,125, 80 and $50 \mu \mathrm{m}$ sieves. The remaining suspension was centrifuged at $500 \mathrm{~g}$ for $1 \mathrm{~min}$ at $20{ }^{\circ} \mathrm{C}$. The supernatant was centrifuged at $3000 \mathrm{~g}$ for $7.5 \mathrm{~min}$ at $20{ }^{\circ} \mathrm{C}$ to obtain the crude starch. The crude starch was suspended in $0.05 \mathrm{M} \mathrm{NaOH}$ and stirred for $48 \mathrm{~h}$. The suspension was again centrifuged at $3000 \mathrm{~g}$ for $7.5 \mathrm{~min}$ at $20{ }^{\circ} \mathrm{C}$ and the supernatant was discarded. The white starch pellet also obtained a grey layer composed of protein, which was removed. The pellet was centrifuged four times at $3000 \mathrm{~g}$ for $7.5 \mathrm{~min}$ at $20{ }^{\circ} \mathrm{C}$ to purify the starch. Finally, the pellet was suspended in Milli-Q water and frozen overnight and subsequently freeze-dried for 72 h (Chris Epsilon 2-6D Freeze Dryer, Osterode am Harz, Germany). The dried starch isolate was ground with an IKA A11 basic grinder (IKA-Werke $\mathrm{GmbH}$ and Co., Staufen, Germany) for a few seconds to obtain a powder. Samples were then stored at $4 \pm 1{ }^{\circ} \mathrm{C}$ in a cold room until further analyses.

\subsubsection{Compositional analysis}

The protein content was measured by Dumas analysis (Nitrogen analyser, FlashEA 1112 series, Thermo Scientific, Interscience, Breda, The Netherlands). A conversion factor of 5.85 was used to convert nitrogen values to protein. The oil content was determined by using a fully automated Büchi extraction system B-811 (Büchi Labortechnik AG, Flawil, Switzerland). The oil extraction was performed with petroleum ether (boiling range $40-60{ }^{\circ} \mathrm{C}$ ) in Standard Soxhlet 
mode for $3 \mathrm{~h}$ with a sample-to-solvent ratio of 1:6. The extracted oil was determined by the difference in weight of the oil beakers, before and after the extraction. The total dietary fibre content was determined according to AACC method 32-05.01 using the Megazyme assay kit K-TDFR (Megazyme International, Bray, Ireland). The ash content was determined according to AACC official method 08-01 (AACC, 1983). All analysis were performed in triplicate for every sample.

\subsubsection{Thermal analysis}

The thermograms of the samples were obtained by differential scanning calorimetry (DSC) (Pyris ${ }^{\mathrm{tm}}$ Diamond DSC, PerkinElmer, Waltham, MA, USA) using stainless steel pans. About $15 \mathrm{mg}$ of dry sample was weighed into the pan and water was added. The DSC analyser was calibrated with indium and an empty pan was used for reference. Samples were heated from 20 to $120{ }^{\circ} \mathrm{C}$ at a rate of $10{ }^{\circ} \mathrm{C} / \mathrm{min}$. The thermal parameters of the peaks $\left({ }^{\circ} \mathrm{C}\right)$ and the enthalpy of denaturation $(\mathrm{J} / \mathrm{g})$ were recorded. The thermal analysis was done in triplicate for each sample.

\subsubsection{Pasting properties}

The pasting properties were determined according to a standard pasting method (AACC, 1999), using a Rapid Visco-Analyzer-4 (RVA) (Newport Scientific Pvt. Ltd., Warriewood, Australia). The samples were suspended in demineralised water to a total water content of $14 \%(\mathrm{w} / \mathrm{v})$. RVA cups were filled with $28.5 \mathrm{~g}$ of the dispersions, placed into the RVA and stirred at a speed of $960 \mathrm{~g}$ during the first $10 \mathrm{~s}$, followed by stirring at $160 \mathrm{~g}$ during the rest of the experiment. The temperature profile was held at $50{ }^{\circ} \mathrm{C}$ for $1 \mathrm{~min}$, increased to $95{ }^{\circ} \mathrm{C}$ in $3 \mathrm{~min}$ and $42 \mathrm{~s}$, hold at $95{ }^{\circ} \mathrm{C}$ for $2.5 \mathrm{~min}$, cooled back to $50{ }^{\circ} \mathrm{C}$ in $3 \mathrm{~min}$ and $42 \mathrm{~s}$, and hold at $50{ }^{\circ} \mathrm{C}$ for $2 \mathrm{~min}$. The results were analysed with Thermocline software (Newport Scientific Pvt. Ltd., Warriewood, Australia). All experiments were performed in triplicate.

\subsubsection{Water retention capacity (WRC)}

The fractions used to determine the water retention capacity (WRC) and solubility were milled as fine as possible using a lab scale mill (Fritsch Mill Pulverisette 14, Idar-Oberstein, Germany) at room temperature. A sieve with a $0.2 \mathrm{~mm}$ screen was used to mill the protein-enriched fraction, while for flour and starch a sieve with a $0.02 \mathrm{~mm}$ screen was used. The rotor speed was $10000 \mathrm{~g}$ with a feed rate of $\sim 20 \mathrm{~g} / \mathrm{min}$. Additionally, the recomposed flour was prepared using the previously milled protein-enriched and starch fractions and weighted according to 
their respective proportion to obtain the same composition of the whole seed flour (see Table $5.2)$.

The WRC of the flour, recomposed flour, protein-enriched and starch fractions were measured by first adding an excess amount of water to the fractions, to obtain a $10 \% \mathrm{w} / \mathrm{w}$ dispersion of each of the various materials in $2 \mathrm{~mL}$ Eppendorf tubes. This dispersion was mixed with a vortex for $2 \mathrm{~h}$ until the sample was thoroughly hydrated. After hydration, the dispersions were heated in an Eppendorf thermomixer (Eppendorf AG, Hamburg, Germany) at different temperatures $\left(20,40,60,80\right.$ and $\left.95^{\circ} \mathrm{C}\right)$ and stirred at $1400 \mathrm{~g}$ for $30 \mathrm{~min}$. After heating, the dispersions were left at room temperature for $2 \mathrm{~h}$. Subsequently, the tubes were centrifuged at $3000 \mathrm{~g}$ for $20 \mathrm{~min}$. The supernatant was separated and later used for solubility experiments and the pellet was weighed. Afterwards, the pellet was dried in an oven at $105^{\circ} \mathrm{C}$ for $24 \mathrm{~h}$ and weighed again. The weight difference between the wet and dry samples relative to the weight of the dry sample was used to calculate the WRC, according to Eq. (5.1).

$W R C(\%)=\frac{W_{\text {wet sample }}-W_{\text {dry sample }}}{W_{\text {dry sample }}} \cdot 100$ Equation 5.1 where $W_{\text {wet sample }}$ is the weight of the wet sample after centrifugation and $W_{\text {dry sample }}$ is the weight of the dry matter of the sample. All samples were measured in triplicate.

\subsubsection{Solubility}

The supernatants that were obtained after centrifugation of the dispersions (Section 5.3.6) were dried at $105{ }^{\circ} \mathrm{C}$ for $24 \mathrm{~h}$, to determine the amount of material that dissolved during the WRC experiments. The solubility of the material was calculated using the following Equation 5.2.

Solubility $(\%)=\frac{W_{\text {drysup }}}{W_{\text {fraction }}} \cdot 100$

in which $W_{d r y ~ s u p}$ is the weight of the remaining dry matter after drying the supernatant and $W_{\text {fraction }}$ is the original dry weight of the material used to make the dispersion $(10 \% \mathrm{w} / \mathrm{w})$ mentioned in the above section (Section 5.3.6). This experiment was performed three times for each condition studied. 


\subsubsection{Static light scattering}

For particle size analysis, flour, protein-enriched and starch-enriched fractions were milled into flour using a ZPS50 impact mill (Hosokawa-Alpine, Augsburg, Germany). To study the effect of heating on the particle size, the protein-enriched and starch-enriched fractions were dispersed in Millipore water in a $15 \mathrm{~mL}$ Falcon tube. For each fraction, solutions of 5\% (w/v) were prepared and heated at $20,40,60,80$ and $95{ }^{\circ} \mathrm{C}$ for $30 \mathrm{~min}$. The particle size distribution was determined with a Mastersizer -3000 (Malvern Instruments Ltd., Malvern, UK) with a wet module (Hydro SM) and a dry module for powders (Aero S). The analyses were done using a Fraunhofer scattering analysis. All samples were measured in triplicate.

\subsubsection{Statistical analysis}

All analyses were performed using Statgraphics Centurion XVI software (StatPoint Inc., Warrenton, VA, USA). To detect significant differences between means, one-way analysis of variance (ANOVA) with separation of means by Fisher's least significant difference (LSD) test was applied. A difference was taken to be statistically significant when the $\mathrm{p}$-value was $<0.05$. The multiple range test (MRT) included in the statistical program was used to prove the existence of homogeneous groups within each of the parameters analysed.

\subsection{Results and discussion}

\subsubsection{Pre-milling and sieving separation}

The milled quinoa seeds were fractionated by sieving, producing four fractions (Figure 5.1). The fractions obtained with a particle size $>0.800 \mathrm{~mm}$ and between $0.630-0.315 \mathrm{~mm}$ were analysed on their composition, while the other two fractions were only analysed on their protein content because for these fractions a low protein yield and PSE were obtained. The other components of these two fractions were not analysed and the non-protein part of was labelled as 'other components'. The embryo that surrounds the perisperm is part of the bran fraction and it is particularly rich in proteins and lipids (Abugoch, 2009). 
A

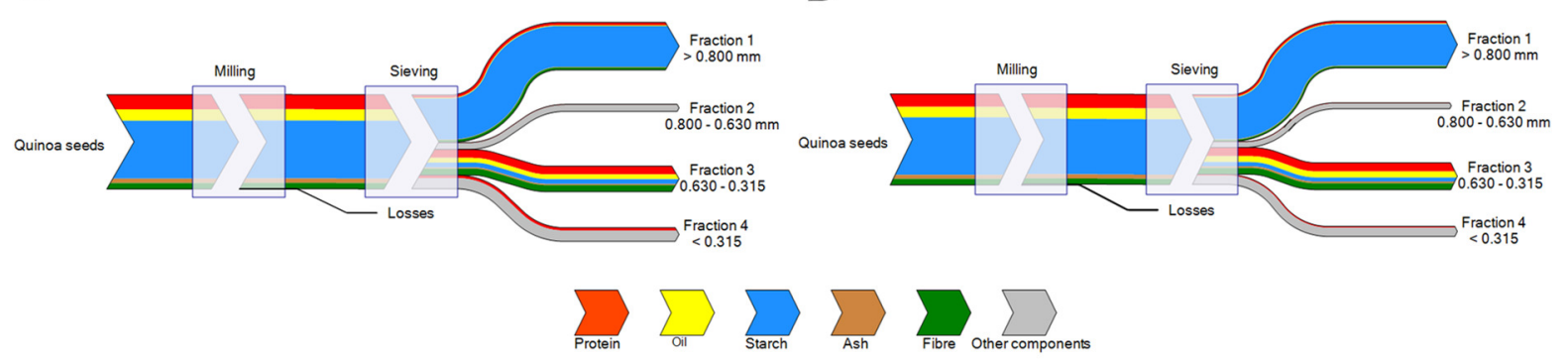

Figure 5.1. Relative composition of quinoa varieties (A) Atlas and (B) Riobamba during the dry fractionation process.

Table 5.1 confirms the effective removal of the embryo from fractions 1,2 and 4, generating a protein-enriched embryo fraction $3(0.630-0.315 \mathrm{~mm})$. Although the yield of this fraction is about 27-30\%, the protein separation efficiency (PSE) of this fraction is high. The yield of fraction 1 (>0.800 mm) was higher and is composed mainly of perisperm. Ando et al. (2002) removed the perisperm from the seed and obtained a protein separation efficiency (PSE) of $59 \%$, while we achieve in this study a PSE of $57 \%$ for Atlas and of $67 \%$ for Riobamba. The protein-enriched fraction 3 consisted mainly of radicles/cotyledons. The same was found by Opazo-Navarrete et al. (2017) in a bitter variety of quinoa in which the embryo was successfully separated from the seed. Föste et al. (2015) reported similar results after milling, fractionation and subsequent wet purification of quinoa bran obtained a fraction with a protein content of $31.3 \%$.

The protein-enriched fractions obtained from Atlas and Riobamba varieties presented similar protein content. However, the variety Riobamba presents a higher PSE value than the Atlas variety.

Table 5.1. Protein content, yield and protein separation efficiency (PSE) of Atlas and Riobamba quinoa fractions after pre-milling and sieving. ${ }^{1}$

\begin{tabular}{|c|c|c|c|c|c|c|c|}
\hline & \multirow{2}{*}{ Fractions } & \multicolumn{2}{|c|}{ Protein Content \% (db) } & \multicolumn{2}{|c|}{ Yield (\%) } & \multicolumn{2}{|c|}{ PSE $(\%)$} \\
\hline & & Atlas & Riobamba & Atlas & Riobamba & Atlas & Riobamba \\
\hline 1 & $>0.800 \mathrm{~mm}$ & $6.08 \pm 0.17$ & $4.86 \pm 0.13$ & $50.5 \pm 0.23$ & $51.6 \pm 2.59$ & $19.7 \pm 0.09$ & $17.7 \pm 0.89$ \\
\hline 2 & $0.800-0.630 \mathrm{~mm}$ & $7.32 \pm 0.74$ & $10.5 \pm 0.34$ & $7.40 \pm 0.17$ & $6.60 \pm 0.09$ & $3.50 \pm 0.08$ & $4.90 \pm 0.06$ \\
\hline 3 & $0.630-0.315 \mathrm{~mm}$ & $32.7 \pm 1.95$ & $32.0 \pm 0.42$ & $27.2 \pm 0.25$ & $29.6 \pm 1.49$ & $57.1 \pm 0.53$ & $66.9 \pm 3.39$ \\
\hline 4 & $<0.315 \mathrm{~mm}$ & $21.0 \pm 0.53$ & $12.2 \pm 0.55$ & $14.4 \pm 0.24$ & $11.0 \pm 1.33$ & $19.5 \pm 0.33$ & $9.50 \pm 1.13$ \\
\hline
\end{tabular}

$\mathrm{db}=$ dry basis

${ }^{1}$ Values are shown as mean \pm standard deviation $(n=9)$ 
Another observation to highlight is the oil content in the protein-enriched fraction (Table 5.2). The application of a further dry separation could be complicated due to the presence of the oil in the enriched-protein fraction. However, the presence of the oil could also be beneficial in some applications as a food ingredient.

Fraction $1(>0.800 \mathrm{~mm})$ has a high starch content $(86-89 \%)$ and a low protein content (4 $6 \%$ ) (Table 2) and may be used directly in the formulation of food products.

As shown in Table 5.2, the amount of water and chemicals required to extract protein by wet fractionation method is relatively high, while the dry fractionation method proposed here does not use any water or chemicals. This also implies that no raw material can be lost in the wastewater. This means that the dry fractionation of quinoa seeds by pre-milling and subsequent sieving is a more sustainable and environmentally friendly process. Even when the protein purity of the fractionated fractions is low, the dry fractionation of quinoa seeds can be interesting for the industries of gluten-free products. Quinoa has been recommended by the World Gastroenterology Organization for celiac disease patients and as a base ingredient for baby foods due to their low allergenicity (WGO, 2012). 


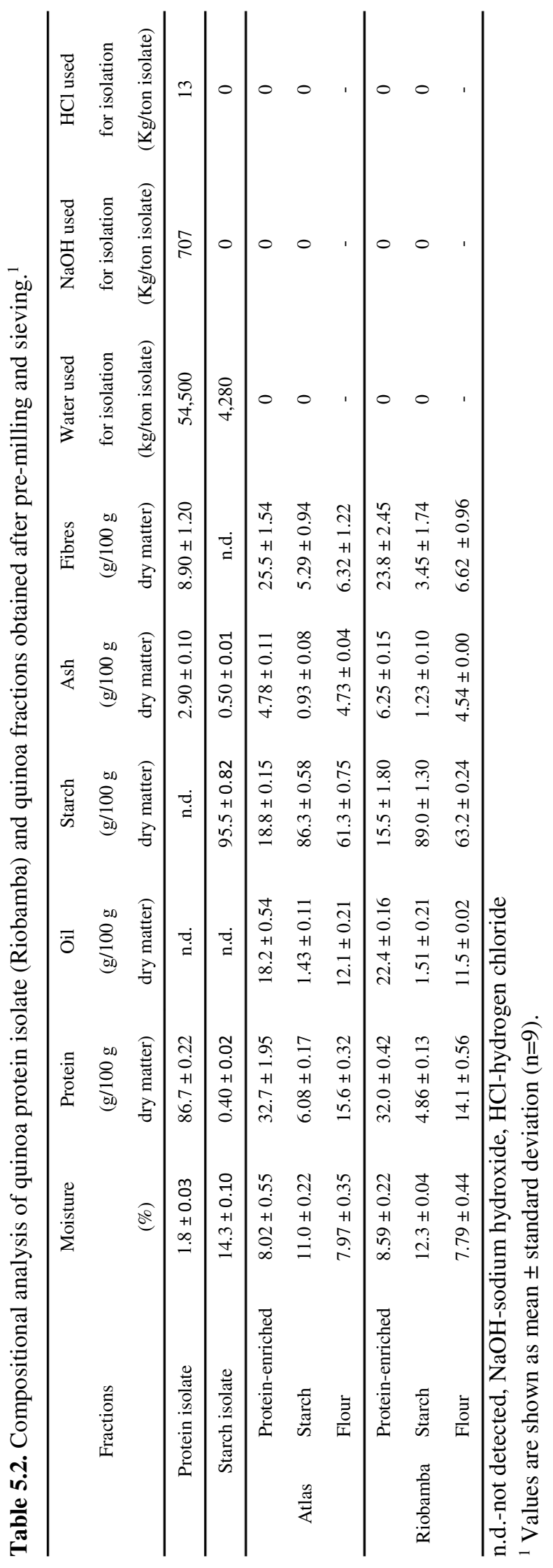




\subsubsection{Characterization of quinoa fractions}

\subsubsection{Thermal characterization of quinoa fractions}

Table 5.3 presents DSC analysis of the different fractions of the Atlas and Riobamba varieties obtained by dry fractionation. The thermograms of flour and protein-enriched fractions showed two peaks corresponding to starch gelatinization and protein denaturation, while the protein isolate (Riobamba) that was produced with wet isolation, did not present any peak. This indicates that the protein in the protein isolate was denatured/unfolded during the wet isolation process. The thermograms of the dry separated starch fractions and the wet separated starch isolate (Riobamba) only showed a starch gelatinization peak.

The starch gelatinization ( $T_{p}$, peak temperature; $T_{o}$, onset temperature and $T_{c}$ : completion temperature) of the starch isolate and starch fractions obtained by dry fractionation did not show significant differences $(\mathrm{p}>0.05)$. However, for the flours and protein-enriched dry fractions a significant increase $(\mathrm{p}<0.05)$ of the temperature of the peaks $T_{o}$ and $T_{p}$ was found. This may be attributed to the retardation of moisture ingression produced by the surrounding proteins, which delays the starch hydration and swelling (Chen et al., 2015). The gelatinization enthalpy values $\left(\Delta H_{1}\right)$ are significantly different $(\mathrm{p}<0.05)$ for each type of fractions. The starch isolates presented the highest value $(15.7 \mathrm{~J} / \mathrm{g}$ starch), followed by the protein-enriched fractions (10.6 $12.9 \mathrm{~J} / \mathrm{g}$ starch) and the starch dry fractions (8.5-9.6 J/g starch) and flours (7.3 - $7.8 \mathrm{~J} / \mathrm{g} \mathrm{starch}$ ). To explain the differences in $\Delta H$ of starch between the samples obtained via wet and dry fractionation method, we hypothesize that during wet separation of starch, amylose may have leached out. Amylose is reported to have a lower $\Delta H$ than amylopectin (Liu et al., 2006), so the remaining fraction would have a higher $\Delta H$. Yu et al. (2016) investigated the effect of amylose content on enthalpy of rice starch. They found that an increase of amylose content produced a decrease in $\Delta H$. Therefore, low enthalpy values may be attributed to low molecular weight and chain length distribution of amylopectin (Jayakody et al., 2007). Alternatively, the lower $\Delta H$ found in the protein-enriched and flours fractions might be an effect of the presence of nonstarch components in the fractions. Fan et al. (1999), reported that non-starch components in rice flour such as protein, ash, fibre and lipids lower the enthalpy for gelatinization.

The second peak in the thermograms corresponds to the protein denaturation temperature $\left(T_{p 2}\right)$. The protein denaturation temperature of Riobamba variety is significantly lower $(p<0.05)$ than 
that of the Atlas variety. The denaturation enthalpy $\left(\Delta H_{2}\right)$ of Atlas and Riobamba flours are both significantly different $(\mathrm{p}<0.05)$ compared to protein-enriched fractions.

Table 5.3. Thermal properties of quinoa flour, protein-enriched and starch fractions of Atlas and Riobamba varieties obtained by the dry fractionated method. ${ }^{1,2}$

\begin{tabular}{|c|c|c|c|c|c|c|c|c|c|}
\hline \multirow{2}{*}{\multicolumn{2}{|c|}{ Fractions }} & \multicolumn{4}{|l|}{ Peak I } & \multicolumn{4}{|c|}{ Peak II } \\
\hline & & $T_{o l}\left({ }^{\circ} \mathrm{C}\right)$ & $T_{p l}\left({ }^{\circ} \mathrm{C}\right)$ & $T_{c l}\left({ }^{\circ} \mathrm{C}\right)$ & $\Delta H_{l}(\mathrm{~J} / \mathrm{g})$ & $T_{o 2}\left({ }^{\circ} \mathrm{C}\right)$ & $T_{p 2}\left({ }^{\circ} \mathrm{C}\right)$ & $T_{c 2}\left({ }^{\circ} \mathrm{C}\right)$ & $\Delta H_{2}(\mathrm{~J} / \mathrm{g})$ \\
\hline \multicolumn{2}{|c|}{ Protein isolate } & - & - & - & - & - & - & - & - \\
\hline \multicolumn{2}{|c|}{ Starch isolate } & $63.2 \pm 0.6^{\mathrm{a}}$ & $70.0 \pm 0.3^{\mathrm{a}}$ & $78.2 \pm 1.2^{\mathrm{a}}$ & $15.0 \pm 1.1^{\mathrm{d}}$ & - & - & - & - \\
\hline \multirow{3}{*}{ Atlas } & Flour & $66.5 \pm 0.2^{\mathrm{b}}$ & $73.3 \pm 0.5^{\mathrm{c}}$ & $80.3 \pm 0.4^{\mathrm{a}}$ & $4.8 \pm 0.4^{\mathrm{b}}$ & $95.6 \pm 1.3^{\mathrm{ab}}$ & $99.2 \pm 0.5^{\mathrm{ab}}$ & $102.8 \pm 0.5^{\mathrm{a}}$ & $1.6 \pm 1.2^{\mathrm{a}}$ \\
\hline & Protein-enriched & $67.1 \pm 0.0^{\mathrm{d}}$ & $73.3 \pm 0.5^{\mathrm{c}}$ & $80.6 \pm 0.0^{\mathrm{a}}$ & $2.0 \pm 0.0^{\mathrm{a}}$ & $95.1 \pm 0.3^{\mathrm{ab}}$ & $100.5 \pm 0.1^{b}$ & $103.9 \pm 1.1^{\mathrm{a}}$ & $6.7 \pm 0.1^{\mathrm{c}}$ \\
\hline & Starch & $62.7 \pm 1.0^{\mathrm{a}}$ & $70.0 \pm 0.7^{\mathrm{a}}$ & $78.4 \pm 0.7^{\mathrm{a}}$ & $8.3 \pm 0.0^{c}$ & - & - & - & - \\
\hline \multirow{3}{*}{ Riobamba } & Flour & $65.6 \pm 0.4^{\mathrm{b}}$ & $72.6 \pm 0.8^{b c}$ & $80.5 \pm 2.0^{\mathrm{a}}$ & $4.6 \pm 1.4^{\mathrm{b}}$ & $96.2 \pm 0.9^{b}$ & $98.5 \pm 1.5^{\mathrm{ab}}$ & $101.9 \pm 2.1^{\mathrm{a}}$ & $4.9 \pm 0.4^{b}$ \\
\hline & Protein-enriched & $65.8 \pm 1.0^{\mathrm{c}}$ & $71.8 \pm 1.7^{\mathrm{c}}$ & $78.1 \pm 2.4^{\mathrm{a}}$ & $2.0 \pm 0.4^{\mathrm{a}}$ & $93.8 \pm 0.0^{\mathrm{a}}$ & $97.8 \pm 0.9^{\mathrm{a}}$ & $101.4 \pm 2.1^{\mathrm{a}}$ & $6.8 \pm 1.4^{\mathrm{c}}$ \\
\hline & Starch & $64.1 \pm 0.7^{\mathrm{a}}$ & $70.9 \pm 0.5^{\mathrm{ab}}$ & $78.8 \pm 1.2^{\mathrm{a}}$ & $7.6 \pm 1.5^{\mathrm{c}}$ & - & - & - & - \\
\hline
\end{tabular}

$T_{o}$-onset temperature, $T_{p}$-peak temperature, $T_{c}$-conclusion temperature, $\Delta H$-enthalpy.

${ }^{1}$ Values are shown as mean \pm standard deviation $(\mathrm{n}=9)$.

${ }^{2}$ Different letters in each column for each fraction indicate significant differences $(\mathrm{p}<0.05)$.

\subsubsection{Pasting properties of quinoa fractions}

Pasting profiles for quinoa fractions are presented in Figure 5.2. Protein-enriched fractions showed reduced viscosity, compared to the whole seed flours, while starch was much higher. The Atlas starch showed a slightly higher pasting curve than Riobamba. This could be a consequence of the higher amount of fibre in the Atlas starch fraction. Sun et al. (2015) found that when wheat starch was added to the wheat and mung bean starch, the starches increased the peak viscosity. The wet isolated starch showed a somewhat earlier onset and a lower peak than the dry separated starches.

The starch fractions showed higher viscosity than flours and protein-enriched fractions. The viscosity is directly related to the starch content in the fractions. The viscosity and retrogradation of the starch granules increased with an increase of the starch content. However, it is not the case. Starch isolate obtained by wet fractionation method (starch purity of 95\%) showed lower viscosity than starch fractions obtained by dry fractionation method. It could be due to the presence of fibre in the dry fractionated samples.

The differences in pasting behaviour between the quinoa starches could be influenced by the different ratios of amylose and amylopectin in starch, resulting in different degrees of 
gelatinization. The finding that the setback (final viscosity minus minimum viscosity after peak viscosity) for starch isolate was significantly smaller $(\mathrm{p}<0.05)$, is in agreement with the hypothesis that amylose leached out during wet isolation. Therefore, when amylose is removed, less retrogradation is expected. Moreover, the granule size could induce the difference in pasting behaviour. The isolated starch via the wet fractionation method is mainly present in individual starch granules with a smaller average particle size $\left(D_{0.5} 1-3 \mu \mathrm{m}\right)$ than the average particle size (starch granules embedded in the matrix) obtained via dry fractionation $\left(\mathrm{D}_{0.5} 92\right.$ $97 \mu \mathrm{m})$ (Fig. 5.3). Sánchez et al. (2000) indicated that native starches with large granules form increasingly more viscous pastes. Possibly, starch granules bound in a matrix, as is the case of the starch isolated by the dry fractionation, could behave as a single larger granule.

The peak time (time to reach the peak viscosity) and pasting temperature increased with the increase of the amount of protein from $62-68{ }^{\circ} \mathrm{C}$ for starch fractions to $91-93{ }^{\circ} \mathrm{C}$ for proteinenriched fractions.

The results obtained in this work showed that the fractions with the higher lipid contents had lower gelation viscosities and started to gelatinize later than the starch isolates. A similar result was found by Horstmann et al. (2016). They found that with an increase of lipid content in corn, tapioca, potato, rice, and gluten-free wheat starches, the temperature of gelatinization increased.

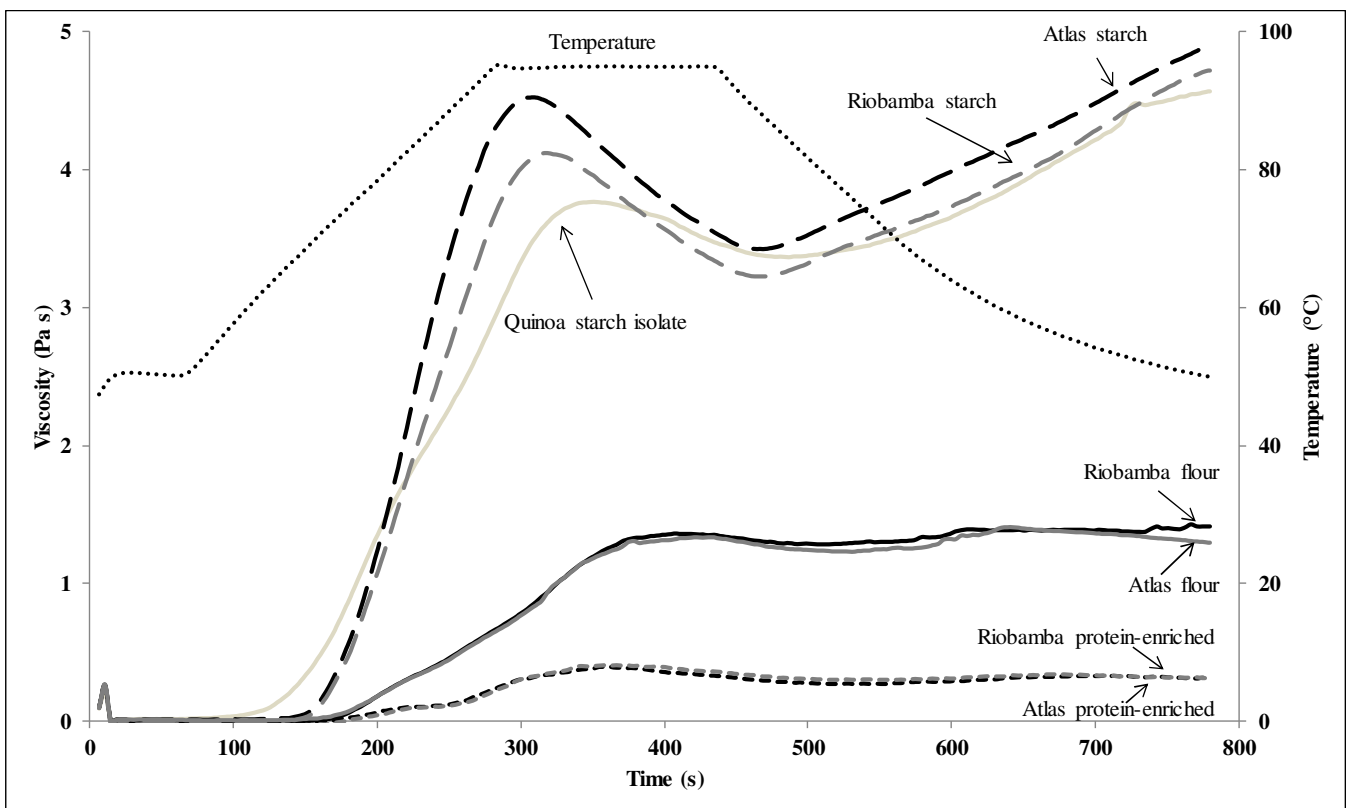

Figure 5.2. Curves of pasting properties (RVA) for quinoa flour, starch and protein-enriched fractions for Atlas and Riobamba varieties obtained by dry fractionation method. 


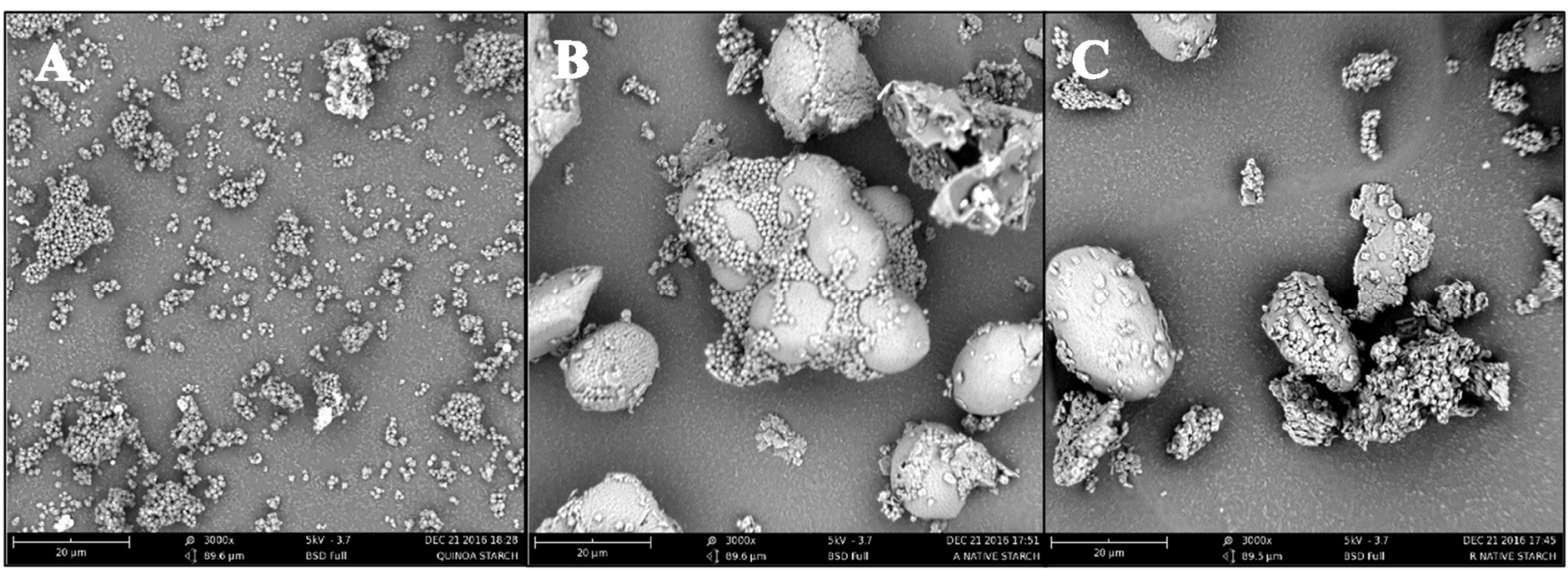

Figure 5.3. Scanning electron microscopy (SEM) images of quinoa starch isolates. (A) Quinoa starch isolate variety Riobamba obtained via wet fractionation, (B) quinoa starch isolate variety Atlas obtained via dry fractionation and $(\mathrm{C})$ quinoa starch isolate variety Riobamba obtained via dry fractionation.

\subsubsection{Functionality of quinoa fractions}

\subsubsection{Water retention capacity (WRC) of quinoa fractions}

Figure 5.4 shows that an increase in the temperature resulted in an increase of the water retention capacity (WRC) for all samples studied. The WRC of the samples heated at $95{ }^{\circ} \mathrm{C}$ was larger than the other samples studied, for all fractions tested. There are not significant differences between the two quinoa varieties. The starch fractions showed higher WRC values in comparison with the other fractions, while protein-enriched fractions presented lower WRC values. A large capacity of starch to absorb water, as well as its ability to form gels after heating are widely known. Therefore, the higher WRC of starch fractions was expected. While the protein-enriched fractions showed a high WRC at low temperatures (until $60{ }^{\circ} \mathrm{C}$ ). This high WRC could be due to a large amount of fibre of this fraction (Table 5.2). However, above 60 ${ }^{\circ} \mathrm{C}$, the slight increase in WRC is led by gelatinization/retrogradation of starch in this fraction. Dhingra et al. (2012) indicated that heating generally changes the ratio soluble to insoluble fibre. Therefore, heating may affect the hydration properties of the fibre.

Finally, the WRCs of protein-enriched and starch fractions were added up with their respective weights to calculate the WRC of a recomposed flour similar in composition as the original flour. The recomposed flour showed similar WRC values than whole seed flour when flours were heated at low temperatures. At temperature close to starch gelatinization, these values seem to move away a little to finally show almost the same WRC than the flour when these were heated at $95{ }^{\circ} \mathrm{C}$. The differences in WRC obtained for the recomposed flour and flour could be due to 
the different particle size of the fractions. A sieve with a bigger screen was used to mill the protein-enriched fraction due to the high amount of oil present in this sample (Table 5.2).
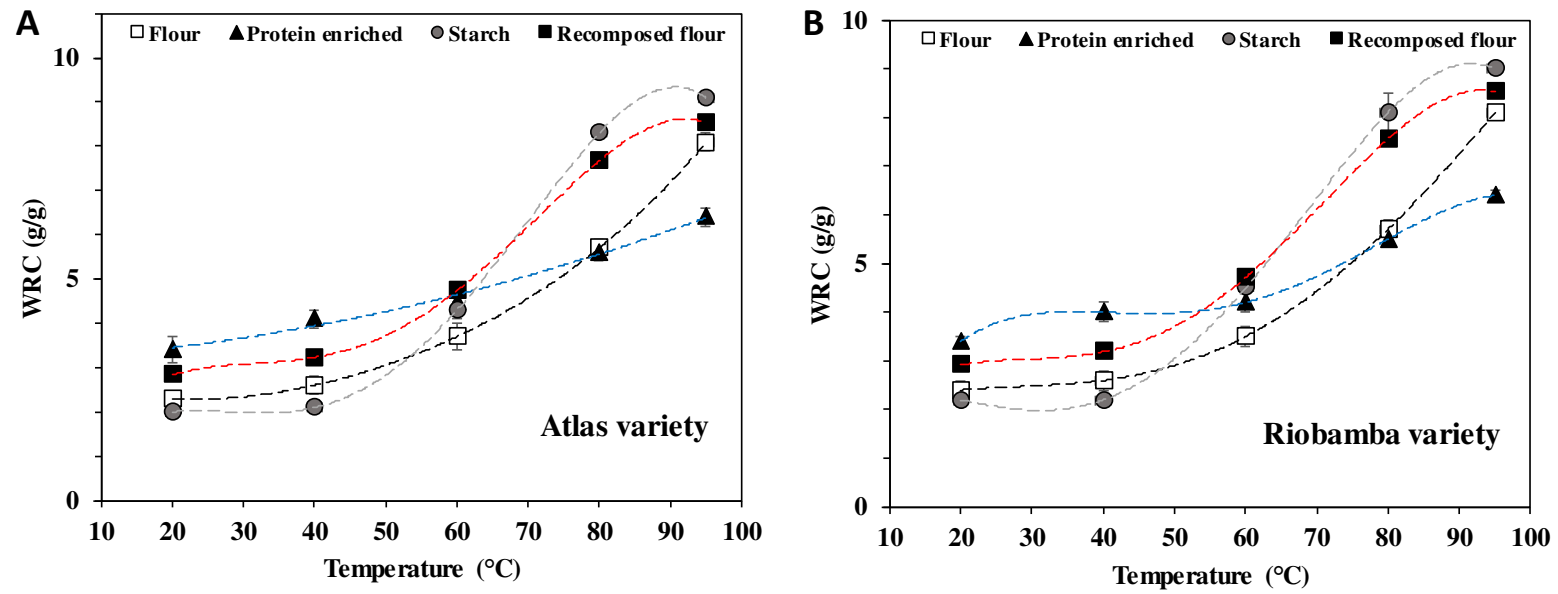

Fig 4. The measured water retention capacity (WRC) of quinoa fractions (g water/g dry matter) after hydration and heating at different temperatures for $30 \mathrm{~min}$. The data of the recomposed flour were calculated based on the composition and the WRC of the single fractions. The lines are drawn to guide the eye.

\subsubsection{Solubility of quinoa fractions}

During the WRC experiments, a certain amount of the material ended up in the supernatant, due to partial dissolution of the material. The data for solubility for starches at a higher temperature $\left(95^{\circ} \mathrm{C}\right)$ are incomplete due to the absence of discernible supernatant. Fig. 5.5 shows that starch, of both varieties, was the least soluble according to our calculations. Overall, a temperature increase resulted in a decrease of the solubility of the material in the supernatant. However, in the temperature range from 20 to $40^{\circ} \mathrm{C}$, an increase of the solubility was observed for all fractions.

The starch fractions showed a decrease in the solubility after heating above $60{ }^{\circ} \mathrm{C}$. This can be explained by gelatinization of the starch after heating. The same explanation is proposed for the decrease in the solubility of the protein-enriched fractions, which contained a high concentration of starch (more than 20\%).

The solubility is affected by the leakage of amylose from starch granules at increasing temperatures (Ahamed et al., 1996), which could be the reason for the decrease in the solubility of the fractions. The same was found by Lindeboom et al. (2005) where values of the solubility increased slightly over the range of $65-95{ }^{\circ} \mathrm{C}$ due to progressive gelatinization of the starch granules. 
The solubility of the reconstituted flour showed that only after heating at $95{ }^{\circ} \mathrm{C}$ almost the same solubility of the flour was reached.
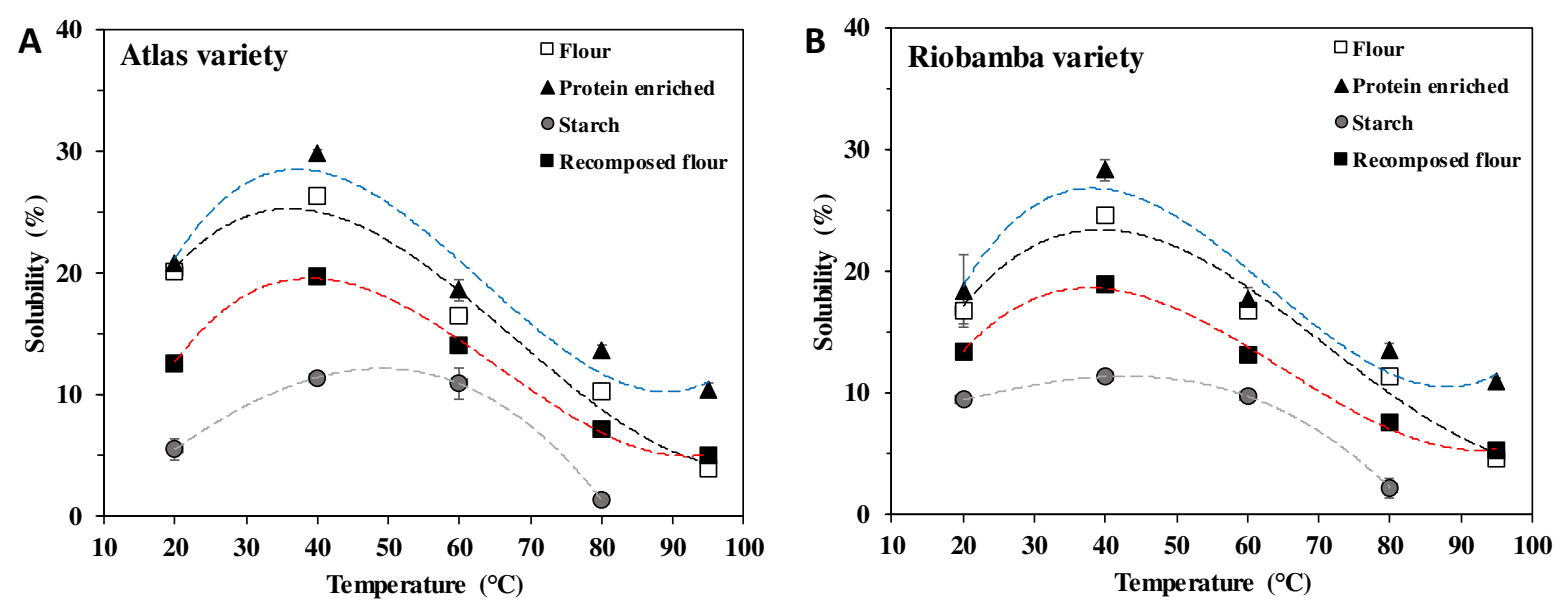

Figure 5.5. Comparison of the solubility (\%) in the supernatant of quinoa fractions (Atlas and Riobamba) after heating for $30 \mathrm{~min}$ at different temperatures. The data of the recomposed flour were calculated based on the composition and the solubility of the single fractions. The lines are drawn to guide the eye.

\subsection{Conclusions}

Enrichment of protein from two sweet quinoa seed varieties (Atlas and Riobamba) was achieved by combining milling and dry separation. The dry fractionation method proposed is an alternative and more sustainable route for producing protein-enriched and starch fractions from quinoa seeds.

Upon sieving, protein-enriched flours ( 32 g protein/100 g dry solids) and starch isolates (86$89 \mathrm{~g}$ starch/100 g dry solids) were obtained. The protein yield and protein separation efficiency were higher for the Riobamba variety. DSC analysis showed that protein-enriched flour obtained by dry fractionation method retained their native properties. The gelatinization temperature of starch is influenced by the residual presence of proteins. The starch isolation method had a pronounced effect on the pasting properties. The protein fractions can be of relevance as functional food ingredients, with a high potential for the application in gluten-free products. 


\subsection{References}

AACC International (1983). Method 08-01: ash - basic method (10th ed.), St. Paul, MN, USA: AACC International.

AACC International (1999). Approved Methods of Analysis, 11th Ed. Method 76-21.01. General pasting methods for wheat or rye flour or starch using the rapid visco analyser, St. Paul, MN. AACC International.

Abugoch, L. E. (2009). Quinoa (Chenopodium quinoa Willd.): Composition, Chemistry, Nutritional, and Functional Properties. Steve L. Taylor (Ed.), Advances in Food and Nutrition Research, Vol. 58 (pp. 1-31). Oxford, UK: Academic Press.

Abugoch, L. E., Romero, N., Tapia, C. A., Silva, J., \& Rivera, M. (2008). Study of some physicochemical and functional properties of quinoa (Chenopodium quinoa Willd.) protein isolates. Journal of Agricultural and Food Chemistry, 56, 4745-4750.

Ahamed, N.T., Singhal, R.S., Kulkarni, P.R., \& Pal, M. (1996). Physicochemical and functional properties of Chenopodium quinoa starch. Carbohydrate Polymers, 31, 99-103.

Ando, H., Chen, Y. -C., Tang, H., Shimizu, M., Watanabe, K., \& Mitsunaga, T. (2002). Food components in fractions of quinoa seed. Food Science and Technology Research, 8(1), 80-84.

Antunez de Mayolo, S.E. (1981). La Nutrición en el Antiguo Perú. Lima: Banco Central de Reserva de Perú, Oficina Numismática.

Avila Ruiz, G., Opazo-Navarrete, M., Meurs, M., Minor, M., Sala, G., van Boekel, M., \& Janssen, A. E. M. (2016). Denaturation and in Vitro Gastric Digestion of Heat-Treated Quinoa Protein Isolates Obtained at Various Extraction pH. Food Biophysics, 11, 184197.

Aiking, H. (2014). Future protein supply. Trends in Food Science \& Technology, 22(2-3), 112120.

Chen, X., He, X., Fu, X., \& Huang, Q. (2015). In vitro digestion and physicochemical properties of wheat starch/flour modified by heat-moisture treatment. Journal of Cereal Science, $63,109-115$. 
Dhingra, D., Michael, M., Rajput, H., \& Patil, R. T. (2012). Dietary fibre in foods: a review. Journal of Food Science and Technology, 49(3), 255-266.

Fan, J., Marks, B. P., Daniels, M. J., \& Siebenmorgen, T. J. (1999). Effects of postharvest operations on the gelatinization and retrogradation properties of long-grain rice. Transactions of the ASABE, 42(3), 727-731.

Föste, M., Elgeti, D., Brunner, A. -K., Jekle, M., \& Becker, T. (2015). Isolation of quinoa protein by milling fractionation and solvent extraction. Food and Bioproducts Processing, 96, 20-26.

Horstmann, S. W., Belz, M. C. E., Heitmann, M., Zannini, E., \& Arendt, E. K. (2016). Fundamental study on the impact of gluten-free starches on the quality of gluten-free model breads. Foods, 5(2), 30.

Jayakody, L., Hoover, R., Liu, Q., \& Donner, E. (2007). Studies on tuber starches. II. Molecular structure, composition and physicochemical properties of yam (Dioscorea sp.) starched grown in Sri Lanka. Carbohydrate polymers, 69(1), 148 - 163.

Li, G., Wang, S., Zhu, F. (2016). Physicochemical properties of quinoa starch. Carbohydrate Polymers, 137, 328-338.

Liu, H., Yu, L., Xie, F., \& Chen, L. (2006). Gelatinization of corn starch with different amylose/amylopectin content. Carbohydrate Polymers, 65, 357-363.

Lindeboom, N., Chang, P. R., Falk, K. C., \& Tyler, R. T. (2005). Characteristics of starch from eight quinoa lines. Cereal Chemistry, 82(2), 216-222.

Maradini, A. M., Ribeiro, M., Da Silve, J. T., Pinheiro, H. M., Paes, J. B., \& Dos Reis, J. S. (2017). Quinoa: Nutritional, functional, and antinutritional aspects. Critical Reviews in Food Science and Nutrition, 57(8), 1618-1630.

Opazo-Navarrete, M., Schutyser, M. A. I., Boom, R. M., \& Janssen, A. E. M. (2017). Effect of pre-treatment on in vitro gastric digestion of quinoa protein (Chenopodium quinoa Willd.) obtained by wet and dry fractionation. International Journal of Food Science and Nutrition, DOI: 10.1080/09637486.2017.1332171

Pelgrom, P. J. M., Vissers, A. M., Boom, R. M., \& Schutyser, M. A. I. (2013). Dry fractionation 
for production of functional pea protein concentrates. Food Research International, 53, 232-239.

Repo-Carrasco-Valencia, R., \& Serna, L. A. (2011). Quinoa (Chenopodium quinua Willd.) as a source of dietary fiber and other functional components. Ciência e Tecnologia de Alimentos, 31(1), 225-230.

Schutyser, M. A. I., \& van der Goot, A. J. (2011). The potential of dry fractionation processes for sustainable plant protein production. Trends in Food Science \& Technologies, 22, 154-164.

Sánchez, T.; Dufour, D.; Moreno, I. X., \& Ceballos, H. N. (2010). Comparison of pasting and gel stabilities of waxy and normal starches from potato, maize, and rice with those of a novel waxy cassava starch under thermal, chemical, and mechanical stress. Journal of Agricultural and Food Chemistry, 58, 5093-5099.

Sun, Q.; Wu, M.; Bu, X.; \& Xiong, L. (2015). Effect of the amount and particle size of wheat fiber on the physicochemical properties and gel morphology of starches. PLOS one, DOI:10.1371/journal.pone.0128665

Yu, S., Liu, J., Yang, Y., Ren, J., Zheng, X., \& Kumar, N. (2016). Effects of amylose content on the physicochemical properties of Chinese chestnut starch. Starch/Stärke, 68, 112118.

Wang, J., de Wit, M., Schutyser, M.A.I., \& Boom, R.M., 2014. Analysis of electrostatic powder charging for fractionation of foods. Innovative Food Science and Emerging Technologies, 26, 360-365.

WGO (2012). Celiac Disease, World Gastroenterology Organisation Global Guidelines. Celiac Disease, World Gastroenterology Organisation Global Guidelines. 


\section{Chapter 6}

The influence of starch and fibre on in vitro protein digestibility of dry fractionated quinoa (Riobamba variety)

This chapter has been submitted as: Opazo-Navarrete, Tagle Freire, D., M., Boom, R.M. \& Janssen, A.E.M. The influence of starch and fibre on in vitro protein digestibility of dry fractionated quinoa (Riobamba variety). 


\subsection{Abstract}

The in vitro gastric digestibility of the quinoa variety Riobamba was investigated, especially the influence of the matrix. Dry-fractionated quinoa protein concentrate, which is just milled and sieved, was much better digestible than the same concentrate that was reconstituted from wet fractionated quinoa protein isolate, quinoa starch isolate, and quinoa fibre isolate. In the reconstituted concentrate, the presence of starch and fibre next to quinoa protein reduces its in vitro gastric digestibility significantly. However, the effect of starch is partially counteracted if fibre is also present. While the effects of starch and fibre separately can be understood from the decrease in matrix accessibility for pepsin, due to the hydrated starch and fibre, we suspect that the synergistic effect of starch and fibre may be due to a relative reduction of the hydration of starch due to the presence of the also strongly hydrating fibre. These conclusions were drawn on the basis of overall measurements of the degree of hydrolysis of the protein during the in vitro digestion, but also with detailed HPSEC chromatography, giving a more comprehensible insight in the peptides and single amino acids that were released during the digestion process. Heating of the matrices to $120{ }^{\circ} \mathrm{C}$ generally resulted in much lower digestion rates, due to extensive aggregation of the protein. 


\subsection{Introduction}

Quinoa (Chenopodium quinoa Willd.), a pseudocereal that is native to South America, has attracted much research interest lately, not only for its nutritional profile but also for its adaptability to different growing conditions (Abugoch, 2009; Li \& Zhu, 2017). Quinoa has a relatively high protein content (14 - 16\%) (Navarro-Lisboa et al., 2017), and presents a wider amino acid spectrum than cereals and legumes (Ruales \& Nair, 1992), with higher lysine (5.1 - 6.4\%) and methionine $(0.4-1.0 \%)$ contents (Bhargava et al., 2003). This makes quinoa complementary to cereals and legumes (Elsohaimy et al., 2015).

$11 \mathrm{~S}$ globulin and $2 \mathrm{~S}$ albumin are the major fraction of proteins in quinoa, representing around $72-77 \%$ of the total protein (Kaspchak et al., 2017; Fischer et al., 2017). The molar mass of $11 \mathrm{~S}$ globulin is $22-23 \mathrm{kDa}$ for the basic subunit and $32-39 \mathrm{kDa}$ for the acid subunit; the molar mass of $2 \mathrm{~S}$ albumin is $8-9 \mathrm{kDa}$ (Brinegar \& Goundan, 1993). The remainder of the proteins is composed mainly of prolamines (Koziol, 1992).

Starch is the major component of quinoa seeds, making up more than $50 \%$ of the dry weight (Lindeboom et al., 2005; Steffolani et al., 2013). The starch granules are rather small (1 - $3 \mu \mathrm{m}$ ) and are usually located in the perisperm of the seed (Lorenz, 1990; Ruales, \& Nair, 1994; Li, \& Zhu, 2017). The starch is mainly constituted of amylose and amylopectin; amylose being a linear glucosyl chain connected by an $\alpha-1,4$ linkage, while amylopectin is highly branched by $\alpha-1,6$ linkages in a clustered manner (Bertoft, 2013). Starch may influence the digestion of proteins, by taking up gastric fluid and physically hindering the ingression of acid and pepsin into the protein.

The fibre content of quinoa is known to be in the between 1.3 and $6.1 \mathrm{wt} \%$ (Navruz-Varli \& Sanlier, 2016). Dietary fibre comes from the carbohydrate parts of the plant cells that are resistant to enzymatic human digestion (Dhingra et al., 2012). By forming a viscous gel-like substance in the digestive system, fibre can slow the transit time of nutrients through the intestines and shield these nutrients from digestion. Besides, evidence suggests that fibre can inhibit the absorption of sugar, cholesterol and various minerals, which may also affect the absorption of protein (Lattimer \& Haub, 2010).

Generally, quinoa is used as food in the same way as cereals because quinoa seeds can be milled into flour or previously dry fractionated to obtain a flour with high protein content (GómezCaravaca et al., 2014; Opazo-Navarrete et al., 2017). However, saponins located in the pericarp 
(seed coats) of quinoa seeds impede its utilization as a practical and commercially attractive food source (Chauhan et al., 1992). Saponins are triterpenoid glucoside compounds found in many plant genera that possess pharmacological properties (Dini et al., 2010), but most saponins have an intensely bitter flavour and all are potentially toxic if ingested in large quantities (Gómez-Caravaca et al., 2014). The levels of the saponins are highly variable among different quinoa varieties and, in accordance with the saponin concentration, quinoa varieties can be classified into sweet quinoa containing $<0.11 \mathrm{wt} \%$ of saponins and bitter quinoa containing $>0.11 \mathrm{wt} \%$ of saponins (Bacigalupo, \& Tapia 2000). Saponins have to be removed by rinsing out with much water, which makes wet processing unattractive, and is incompatible with dry processing. Dry processing represents a more sustainable alternative since it does not use water, requires much less energy and utilises more of the raw material in high-value fractions (Schutyser \& van der Goot, 2011).

From 1999 three sweet varieties have been registered: Atlas (1999), Pasto (2005) and Riobamba (2005). All these varieties have the potential to be dry fractionated. Dry fractionation is more resource efficient, but yields fractions which still contain significant levels of components such as oil, starch and fibres. These components may influence the digestibility of the protein.

A protein with high digestibility has potentially better nutritional value than one with low digestibility because it provides more amino acids for absorption on proteolysis (Pushparaj \& Urooj, 2011). It is known that exogenous (interaction of proteins with non-protein components like polyphenols, non-starch polysaccharides, starch, tannins, dietary fibre, phytates and lipids.) and endogenous factors (changes within the proteins themselves) contribute to poor digestibility of proteins (Pushparaj \& Urooj, 2011). During the process of milling and cooking, proteins may interact with non-protein components and the proteins themselves, thereby affecting their digestibility (Doudu et al., 2003).

We have previously estimated the effect of starch on protein digestibility of a bitter quinoa variety (Opazo-Navarrete et al., 2017) and characterized the fractions of two dry fractionated sweet quinoa varieties (Opazo-Navarrete et al., 2018). However, the effects of fibre and the combined effect of starch and fibre on protein digestibility of quinoa are not yet known. Thus, the aim of this work is to assess the effects of starch and fibre on the in vitro gastric digestion of quinoa proteins suspensions unheated and heated at different temperatures $\left(60\right.$ and $\left.120{ }^{\circ} \mathrm{C}\right)$ of the quinoa variety Riobamba. 


\subsection{Materials and methods}

\subsubsection{Materials}

Quinoa sweet variety Riobamba was acquired from GreenFood50 (The Netherlands).

\subsubsection{Material preparation}

Quinoa seeds were dry fractionated according to the procedure described by Opazo-Navarrete et al. (2018). A protein-enriched flour was obtained by separation of the cotyledons from the seed and subsequently sieving. Quinoa protein was then isolated according to the procedure described by Opazo-Navarrete et al. (2018).

Fibre and starch were isolated from defatted quinoa flour. Defatted quinoa flour was suspended in Milli-Q water $(1: 3 \mathrm{w} / \mathrm{w})$ and stirred for 4 hours at $20{ }^{\circ} \mathrm{C}$. The mix was sieved using three consecutive sieves with a mesh size of 212,90 and $53 \mu \mathrm{m}$, respectively. The residues within the mesh size $90-53 \mu \mathrm{m}$ were separated and oven dried at $80{ }^{\circ} \mathrm{C}$ for $4 \mathrm{~h}$ in order to obtain a fibre concentrate (Dalgetty \& Baik, 2003). The remaining suspension after sieving was centrifuged at $500 \mathrm{xg}$ for $1 \mathrm{~min}$ at $20^{\circ} \mathrm{C}$ in order to sediment the hulls. The resulting supernatant was centrifuged at 3,000 $\mathrm{xg}$ for $8 \mathrm{~min}$ at $20{ }^{\circ} \mathrm{C}$ obtaining a crude starch as a product. The crude starch was suspended in $0.05 \mathrm{M} \mathrm{NaOH}$, stirred for $48 \mathrm{~h}$ at $20^{\circ} \mathrm{C}$ and centrifuged at 3,000 $\mathrm{xg}$ for $8 \mathrm{~min}$ at $20{ }^{\circ} \mathrm{C}$. After a white layer was obtained and removed with a spoon, which was suspended in water and centrifuged again $\left(3,000 \mathrm{xg}, 8 \mathrm{~min}, 20^{\circ} \mathrm{C}\right)$. This was repeated four times in order to obtain high purity. The resulting starch was dried at $40{ }^{\circ} \mathrm{C}$ and 40 mbar in a vacuum oven (Binder VD53, Tuttlingen, Germany).

\subsubsection{Compositional analysis}

The protein content was measured by Dumas analysis (Nitrogen analyser, FlashEA 1112 series, Thermo Scientific, Interscience, Breda, The Netherlands) in triplicate. A conversion factor of 5.85 was used to convert nitrogen values to protein. The oil content was determined with a fully automated Büchi extraction system B-811 (Büchi Labortechnik AG, Flawil, Switzerland). The oil extraction was performed with petroleum ether (boiling range $40-60{ }^{\circ} \mathrm{C}$ ) in Standard Soxhlet mode for $3 \mathrm{~h}$ with a sample-to-solvent ratio 1:6. The extracted oil was determined by the difference in weight of the oil beakers, before and after the extraction. The total dietary fibre content was determined according to AACC method 32-05.01 using the Megazyme assay kit 
K-TDFR (Megazyme International, Bray, Ireland). The ash content was determined according to the AACC official method 08-01 (AACC, 1983).

\subsubsection{Heat treatment of quinoa protein suspensions}

Every component of the quinoa was isolated or concentrated and were subsequently used to reconstitute the quinoa protein concentrate that was also obtained directly via dry fractionation. Therefore, the same amount of starch, fibre or starch/fibre was added to the protein isolate to investigate the effect of every component on the protein digestibility. Later, suspensions of $5 \%$ of protein (\% w/v, in Milli-Q water) were prepared at room temperature in Eppendorf tubes of $2 \mathrm{ml}$. The suspensions were stirred with a Multi Reax shaker (Heidolph Instruments, Schwabach, Germany) for $30 \mathrm{~min}$ at 1,800 rpm. Subsequently, the suspensions were subjected to heat treatment at $60{ }^{\circ} \mathrm{C}$ and 1,400 rpm of shaking in a preheated Eppendorf Thermomixer (Eppendorf AG, Hamburg, Germany). Heating at $120^{\circ} \mathrm{C}$ for $30 \mathrm{~min}$ was carried out in a heating block (Grant GBT4, Cambridge, UK). After heating, the suspensions were immediately cooled and kept at room temperature until measurement the same day.

\subsubsection{In vitro gastric digestion of quinoa suspensions}

The unheated and heated suspensions of $5 \%$ protein (w/v, in Milli-Q water) were incubated in simulated gastric juice (SGJ) at $37{ }^{\circ} \mathrm{C}$ for $3 \mathrm{~h}$. The simulated gastric juice was prepared according to Opazo-Navarrete et al. (2017) with minor modifications. For this, pepsin $(1 \mathrm{~g} / \mathrm{L})$ and $\mathrm{NaCl}(8.775 \mathrm{~g} / \mathrm{L})$ were dissolved in Milli-Q water and the $\mathrm{pH}$ was adjusted to 2 using $2 \mathrm{M}$ $\mathrm{HCl}$. The enzyme:substrate ratio was kept constant at 1:2 (weight/weight) during all experiments. The vessels containing the SGJ were continuously stirred at $100 \mathrm{rpm}$ and sealed with parafilm (Pechiney Plastic Packaging, Inc., IL, U.S.A) to avoid evaporation. Samples of 1 $\mathrm{ml}$ were taken at 20,60, 120 and $180 \mathrm{~min}$ and immediately heated in a Thermomixer at $90{ }^{\circ} \mathrm{C}$ and 1,400 rpm of shaking for $5 \mathrm{~min}$ in order to inactivate the pepsin. The $\mathrm{pH}$ of these samples was approximately 6. All digestion experiments were performed in triplicate.

\subsubsection{High-Performance Size Exclusion Chromatography (HPSEC)}

The SGJ, undigested and in vitro digested samples were analysed via high-performance size exclusion chromatography using an Ultimate 3000 UHPLC system (Thermo Scientific, MA) equipped with a TSKgel G3000SWXI column (7.8mm X $300 \mathrm{~mm}$ ) (Tosoh Bioscience LLC, PA) and TSKgel G2000SWXl column (7.8mm X $300 \mathrm{~mm}$ ) (Tosoh Bioscience LLC, PA) 
connected in line. For analysis, $1 \mathrm{~mL}$ of undiluted sample was centrifuged at 1,000 rpm for 30 s to separate the large particles. $10 \mu \mathrm{L}$ of the supernatant was injected into the system each time. The mobile phase was acetonitrile (30\%) in Milli-Q water $(70 \%)$ containing trifluoroacetic acid $(0.1 \%)$. The flow rate was $1.5 \mathrm{~mL} / \mathrm{min}$ and the UV detector was set at $214 \mathrm{~nm}$. Calibration was done with: thyroglobulin $(670 \mathrm{kDa})$, g-globulin (158 kDa), ovalbumin (44.3 kDa), $\alpha$ lactalbumin $(14.1 \mathrm{kDa})$, aprotinin $(6.51 \mathrm{kDa})$, insulin $(5.7 \mathrm{kDa})$, bacitracin $(1.42 \mathrm{kDa})$ and phenylalanine (165 Da) (Sigma-Aldrich, Inc., St. Louis, MO, U.S.A.). The molecular mass was estimated against the elution time of molecular weights markers. All measurements were done in duplicate.

\subsubsection{Degree of hydrolysis (DH)}

The OPA method was used to determine the degree of hydrolysis (DH) attained. The OPA reagent and standard L-serine solution were prepared according to Opazo-Navarrete et al. (2017). A standard curve using an L-serine solution was measured in the range of 50 - 200 $\mathrm{mg} / \mathrm{L}$. The OPA assay was carried out by the addition of $200 \mu \mathrm{L}$ of sample (or standard) to 1.5 $\mathrm{mL}$ of OPA reagent. The samples with the OPA reagent added were measured after 3 minutes at $340 \mathrm{~nm}$ with a spectrophotometer DU 720 (Beckman Coulter Inc. Pasadena, CA, U.S.A). The absorbance values were converted to free amino groups (mmol/l) from a standard curve. Free amino group levels from the digestion samples were corrected by subtracting the contribution of free amino groups that were already present in the SGF. The free amino groups were expressed as serine amino equivalents $\left(\right.$ Serine $\left.\mathrm{NH}_{2}\right)$. From this, the $\mathrm{DH}$ values were calculated according to Opazo-Navarrete et al. (2017).

\subsubsection{SDS-PAGE}

The quinoa flour suspensions were analysed under non-reducing SDS-PAGE conditions. The samples were diluted with buffer (0.5 M Tris-HCl, pH 6.8; $2 \mathrm{wt} \%$ SDS; $2.5 \mathrm{wt} \%$ glycerol; 0.2 wt $\%$ bromophenol blue). The weight ratio of sample-to-buffer was 1:1. Each sample was heated to $95{ }^{\circ} \mathrm{C}$ for 4 min in an Eppendorf thermomixer (Eppendorf AG, Hamburg, Germany) and mixing at $800 \mathrm{rpm}$. An amount of $10 \mu \mathrm{L}$ of the molecular weight marker Precision Plus Protein All Blue Standards (Bio-Rad Laboratories Inc., Hercules, USA) and each sample were loaded on a 12\% Tris-HCl Mini-PROTEAN TGX Precast Gel (Bio-Rad Laboratories Inc., USA). The electrophoresis was carried out at $200 \mathrm{~V}$. Afterwards, the gel was stained with Bio-safe 
Coomassie Stain (Bio-Rad Laboratories Inc., USA) and gel images were taken using a GS-900 Calibrated Densitometry System (Bio-Rad Laboratories, Inc., USA).

\subsubsection{Statistical analysis}

Significance testing was performed using the IBM SPSS Statistic 21 for Windows computerized statistical analysis package. DH values were examined using one-way analysis of variance (ANOVA) to compare means between different samples. The differences were taken to be statistically significant when $\mathrm{p}<0.05$. When the F-values were found significant $(\mathrm{p}<$ 0.05), Tukey's multiple comparisons procedure was used to determine any significant differences within the groups (Post Hoc-LSD). Results are expressed as a mean \pm its standard deviation.

\subsection{Results and discussion}

Protein-enriched flour was obtained via dry fractionation. The compositional analysis of every fraction used during the digestion experiments is presented in Table 6.1. Protein-enriched flour had high fibre and oil contents, while the starch content was lower than the original quinoa flour. Starch was successfully isolated using the same dry fractionation method, while fibre could only be concentrated using a wet fractionation method.

Table 6.1. Compositional analysis of quinoa fractions.

\begin{tabular}{lcccccc}
\hline \multicolumn{1}{c}{ Fractions } & Moisture & $\begin{array}{c}\text { Protein } \\
(\mathrm{g} / 100 \mathrm{~g}\end{array}$ & $\begin{array}{c}\text { Oil } \\
(\mathrm{g} / 100 \mathrm{~g}\end{array}$ & $\begin{array}{c}\text { Starch } \\
(\mathrm{g} / 100 \mathrm{~g}\end{array}$ & $\begin{array}{c}\text { Ash } \\
(\mathrm{g} / 100 \mathrm{~g}\end{array}$ & $\begin{array}{c}\text { Fibre } \\
(\mathrm{g} / 100 \mathrm{~g} \\
\text { dry matter })\end{array}$ \\
$\begin{array}{lcccc}\text { dry matter }) \\
\text { dry matter })\end{array}$ \\
\hline Quinoa flour & $7.8 \pm 0.4$ & $14.1 \pm 0.6$ & $11.5 \pm 0.0$ & $63.2 \pm 0.2$ & $4.54 \pm 0.0$ & $6.6 \pm 1.0$ \\
Protein-enriched flour & $8.6 \pm 0.2$ & $32.0 \pm 0.3$ & $22.4 \pm 0.2$ & $15.5 \pm 1.8$ & $6.3 \pm 0.2$ & $23.8 \pm 2.5$ \\
Protein isolate & $1.8 \pm 0.0$ & $86.7 \pm 0.2$ & n.d. & n.d. & $2.9 \pm 0.1$ & n.d. \\
Dry fractionated starch & $7.8 \pm 0.1$ & $4.9 \pm 0.1$ & $1.5 \pm 0.2$ & $89.0 \pm 1.3$ & $1.2 \pm 0.1$ & $3.5 \pm 1.7$ \\
Starch isolate & $14.3 \pm 0.1$ & $0.4 \pm 0.0$ & n.d. & $95.5 \pm 0.8$ & $0.5 \pm 0.0$ & n.d. \\
Fibre concentrate & $2.9 \pm 0.1$ & $12.2 \pm 0.1$ & $0.1 \pm 0.0$ & $37.9 \pm 0.1$ & $5.1 \pm 0.2$ & $44.7 \pm 0.4$ \\
\hline
\end{tabular}

n.d.= not detected

\subsubsection{Effect of protein concentration method and temperature on protein digestibility}

Suspensions of unheated and heated protein were used during in vitro gastric digestion. The $\mathrm{pH}$ was registered throughout the digestion and a generally minor change in $\mathrm{pH}$ was observed over the time of digestion; however, this change was larger with the unheated samples with a $\mathrm{pH}$ change from 2 to 2.3. The degrees of hydrolysis (DH) are shown in Figure 6.1. Protein-enriched 
flour obtained by dry fractionation, whether unheated or heated, showed a higher in vitro gastric protein digestibility than quinoa protein that was isolated using a conventional wet fractionation method. This shows that the protein digestibility is affected by the isolation method of the proteins. Neucere \& Ory (1968) indicated that organic solvents may lead to a decrease in the protein solubility, which could affect the protein digestibility. This already was found by Opazo-Navarrete et al. (2017) on a bitter quinoa variety, who found that quinoa protein concentrated via a dry fractionation method presents higher in vitro gastric digestibility than quinoa protein isolates obtained via a wet fractionation method.

Regardless of the protein concentration method, solutions preheated at $120^{\circ} \mathrm{C}$ present a lower degree of hydrolysis (DH) than the solutions that were unheated or heated at $60{ }^{\circ} \mathrm{C}$. During wet fractionation, organic solvents such as hexane and petroleum ether are used. These solvents are known to cause denaturation of proteins, which results aggregation of the proteins. The quinoa heated at $120{ }^{\circ} \mathrm{C}$ may have become chemically modified, resulting in crosslinks. Similarly, denaturation of the protein could have resulted in aggregation. Both would affect the accessibility of the protein for pepsin. The aggregation was corroborated by microscopy: after heating at $120{ }^{\circ} \mathrm{C}$ quinoa protein isolate (QPI) shows big aggregates. The dry fractionated, protein-enriched flour showed clearly smaller aggregates in comparison to the QPI. This could explain the lower protein digestibility obtained with QPI. This effect by aggregation was previously suggested by Opazo-Navarrete et al. (2017) and Avila et al. (2016) who found that quinoa protein heated at $120{ }^{\circ} \mathrm{C}$ had lower gastric digestibility as a consequence of protein aggregation.
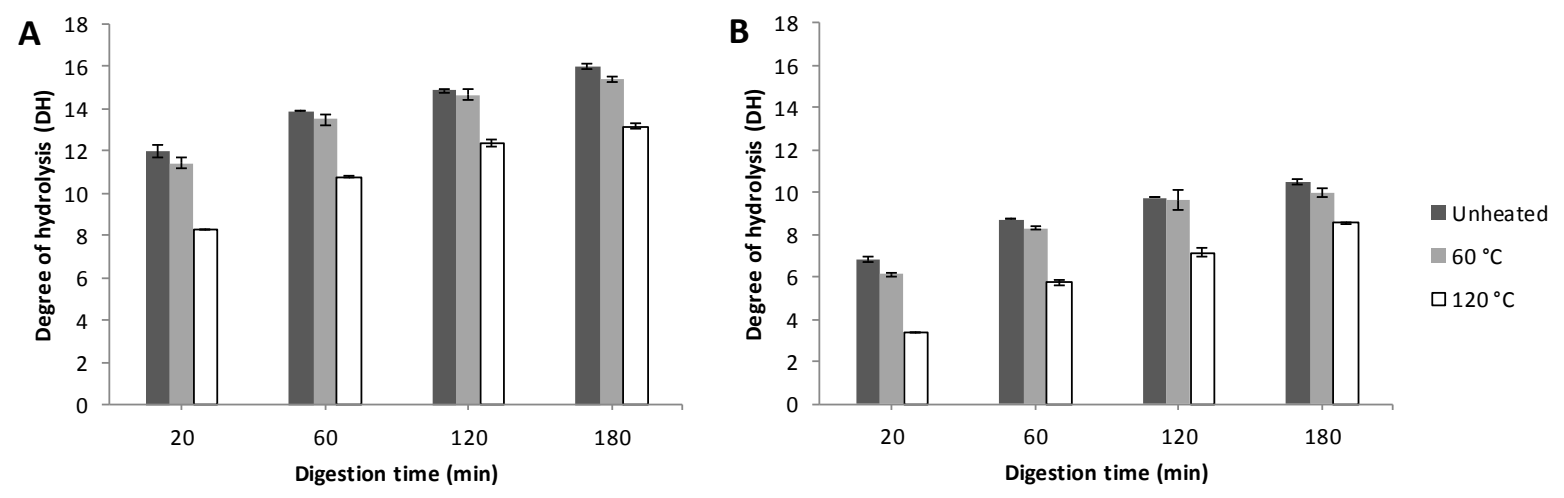

Figure 6.1. In vitro gastric digestibility of unheated and heated (A) quinoa dry fractionated fraction and (B) quinoa protein isolate. 


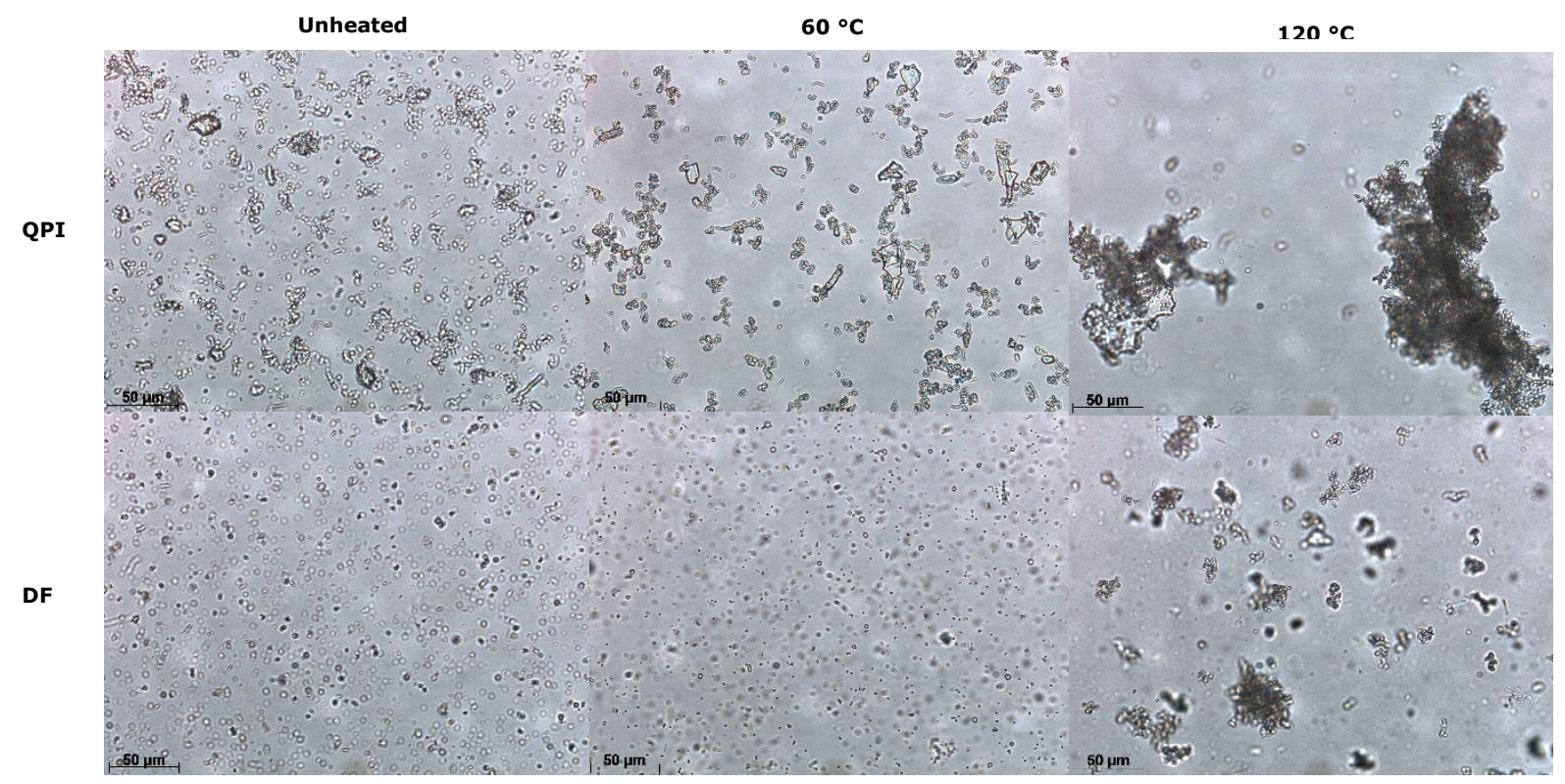

Figure 6.2. Light microscopy images of unheated and heated at 60 and $120^{\circ} \mathrm{C}$ quinoa protein isolate (QPI) and dry fractionated quinoa (DF) dispersions.

The heated and unheated protein-enriched flour suspensions were analysed by HPSEC (Figure 6.3). After digesting unheated and heated quinoa suspensions for $180 \mathrm{~min}$, higher levels of small peptides, ranging from 0.2 to $2 \mathrm{kDa}$, had been released. Quinoa protein suspensions heated at $120{ }^{\circ} \mathrm{C}$ showed less released peptides than quinoa solutions that were unheated or heated at 60 ${ }^{\circ} \mathrm{C}$, but gave larger peptides (> $2 \mathrm{kDa}$ ); even after 180 min of gastric digestion time. These results matched the values obtained for the degree of hydrolysis $(\mathrm{DH})$.

The chromatograms of the digested QPI suspensions (unheated and heated) are presented in Figure 6.4. The level of larger peptides ( $>2 \mathrm{kDa}$ ) from the unheated and heated QPI suspensions is higher than that of the protein-enriched flour suspensions, while less individual amino acids are formed in the QPI suspensions, in comparison with the protein-enriched flour suspensions, both unheated and heated. This higher amount of amino acids formed can be seen in the greater area generated between the elution times of 15 and $15.7 \mathrm{~min}$. This range corresponds to a MW of $75-150 \mathrm{Da}, 75 \mathrm{Da}$ being the MW of lysine, the smallest amino acid.

Both the level of larger peptides, as well as that of the amino acids agree with the DH values that were obtained. The larger peptides that were released from QPI correspond to a greater accessibility of pepsin to the quinoa protein, than with the concentrated flour. 

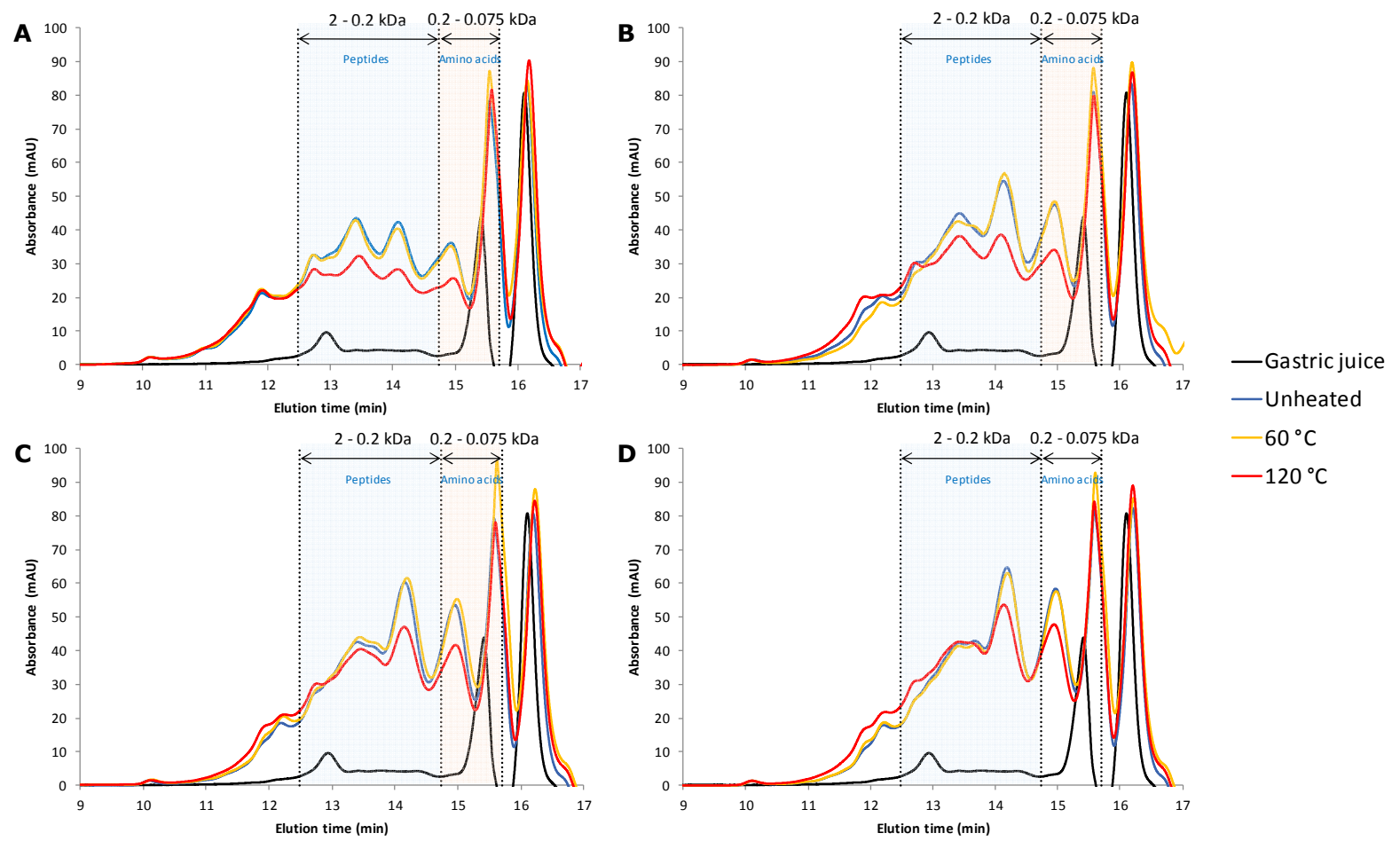

Figure 6.3. HPSEC profiles of gastric digestion of quinoa suspensions prepared with a dry fractionated quinoa fraction and digested by pepsin at $37^{\circ} \mathrm{C}$ for (A) $20 \mathrm{~min}$, (B) $60 \mathrm{~min}$, (C) $120 \mathrm{~min}$ and (D) $180 \mathrm{~min}$.
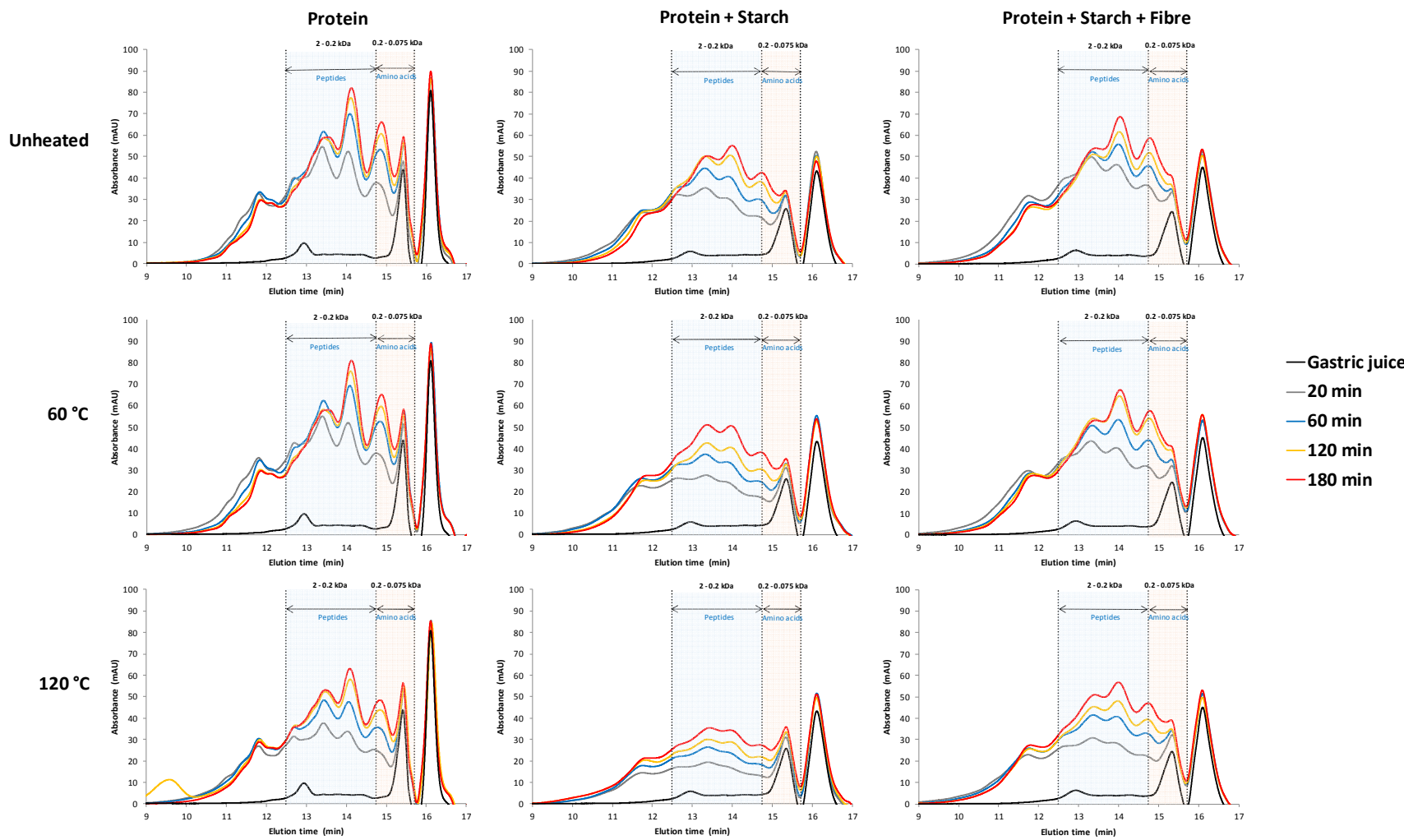

Figure 6.4. HPSEC profiles of gastric digestion of unheated and heated QPI alone and mixed with starch and fibre suspensions digested by pepsin at $37^{\circ} \mathrm{C}$. 
SDS-PAGE results under non-reducing conditions are shown in the Figure 6.5. Proteins with a molecular weight (MW) ranging from $11-66 \mathrm{kDa}$ were found in the unheated and heated at $60{ }^{\circ} \mathrm{C}$ samples, while in the samples heated at $120{ }^{\circ} \mathrm{C}$, no bands were found. The two bands found between 49 - $66 \mathrm{kDa}$ correspond to globulins called chenopodin subunits (11S), while around $10 \mathrm{kDa}$ a band was found corresponding to the albumin subunit $(2 \mathrm{~S})$. Defatting of quinoa flour seems to mainly affect the globulins (11S): these bands are less intense than those of dry fractionated and quinoa flour. The disappearance of bands of samples heated at $120{ }^{\circ} \mathrm{C}$ indicate extensive aggregation of the quinoa proteins into aggregates larger than $250 \mathrm{kDa}$, which are not visible in the gel. This is clearly visible in the chromatograms of the dry fractionated quinoa flour (Figure 6.3) and quinoa protein isolated (Figure 6.4) digested suspensions: at retention times lower than $12.5 \mathrm{~min}(>50 \mathrm{kDa})$ the suspensions that were preheated at $120^{\circ} \mathrm{C}$ showed a larger integrated peak area than the other samples, implying protein aggregation. Therefore, the aggregation might have reduced the accessibility of the proteins to the pepsin, leading to a decrease in the protein digestibility.

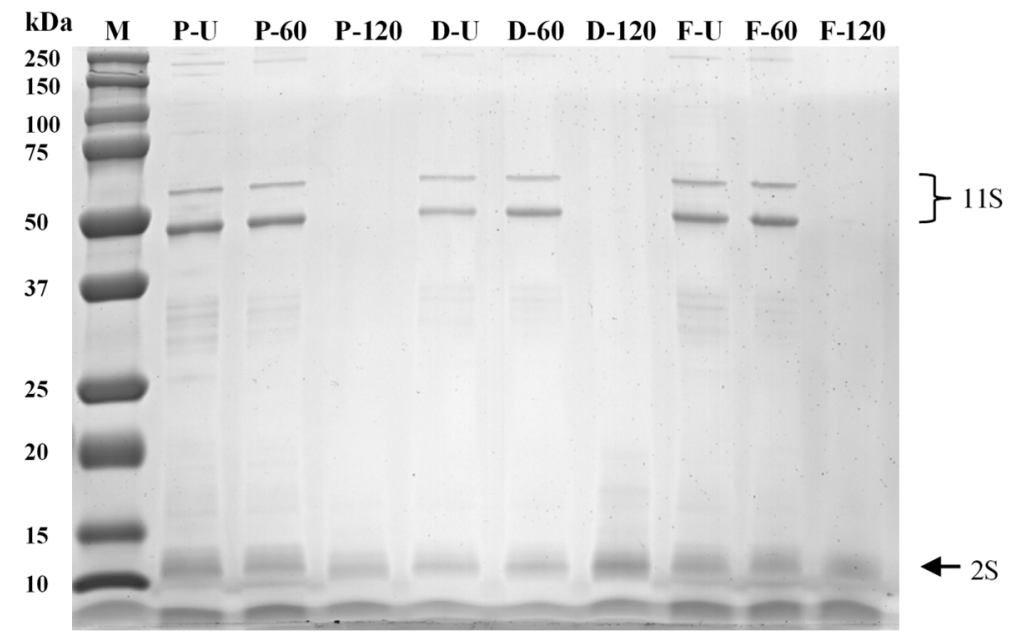

Figure 6.5. SDS-PAGE under non-reducing conditions patterns. M: marker; P-U: protein-enriched flour unheated; P-60: protein-enriched flour heated at $60{ }^{\circ} \mathrm{C}$; P-120: protein-enriched flour heated at $120{ }^{\circ} \mathrm{C}$; D-U: defatted flour unheated; D-60: defatted flour heated at $60^{\circ} \mathrm{C} ; \mathbf{D - 1 2 0}$ : defatted flour heated at $120{ }^{\circ} \mathrm{C}$; F-U: flour unheated; F-60 flour heated at $60{ }^{\circ} \mathrm{C} ; \mathbf{F}-120$ : flour heated at $120^{\circ} \mathrm{C}$.

\subsubsection{Effect of starch on protein digestibility}

To assess the effect of starch on the protein digestibility, the starch that was isolated via wet fractionation was added to the quinoa protein isolate (Figure 6.6) to obtain the same starch concentration as in the dry fractionated protein-enriched fraction (Table 6.1). The oil was 
omitted in this study. Heating was applied to the suspensions to study the combined effect of starch and temperature on the protein digestibility.

The presence of starch reduced the digestion rates of unheated QPI and heated QPI that were heated at $60^{\circ} \mathrm{C}$, but after $180 \mathrm{~min}$ almost the same level of hydrolysis was obtained as without starch (Figure 6.1B). Preheating at $120^{\circ} \mathrm{C}$ gave a strong decrease in the digestion rate and even after 180 minutes, the degree of hydrolysis was still only half of the value obtained without starch. These results show that starch strongly affects the protein digestibility, the effect being most pronounced at $120^{\circ} \mathrm{C}$. Wong et al. (2009) found that the protein digestibility increased considerably when starch was removed from sorghum flour. López-Barón et al. (2017) indicated that heat-induced protein denaturation or protease hydrolysis promote the enhancement of the protein-starch interactions. In their study, these protein-starch interactions reduced the enzymatic starch hydrolysis. The same protein-starch interaction could be responsible for the reduced digestibility of protein after heat-treatment at $120{ }^{\circ} \mathrm{C}$ in our study.

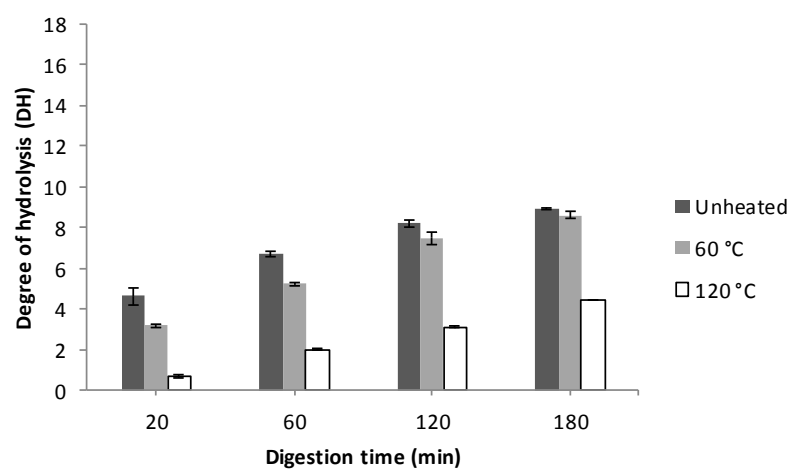

Figure 6.6. The degree of hydrolysis (DH) of quinoa protein-starch suspensions during in vitro gastric digestion.

The chromatograms of quinoa protein-starch suspensions are shown in the Figure 6.4. The chromatograms of unheated and heated at $60{ }^{\circ} \mathrm{C}$ suspensions had a similar integrated peak area after 180 min of gastric digestion, which implies similar peptides and amino acids formation (> $2 \mathrm{kDa}$ ). However, the digestion rate of the suspensions heated at $60{ }^{\circ} \mathrm{C}$ again is lower in the first $120 \mathrm{~min}$, in agreement to the $\mathrm{DH}$ values obtained earlier. The quinoa protein-starch suspensions heated at $120^{\circ} \mathrm{C}$ showed a much lower integrated peak area than the suspensions that were unheated or heated at $60{ }^{\circ} \mathrm{C}$, even after $180 \mathrm{~min}$ of gastric digestion. These results are therefore in agreement with the DH values obtained earlier. 


\subsubsection{Effect of fibre on protein digestibility}

The protein-enriched flour was reconstituted according to the protein, starch and fibre contents (Table 6.1). The oil was omitted in this study. Quinoa starch isolate and fibre concentrate were mixed with quinoa protein isolate to obtain the same concentration as in the dry fractionated protein-enriched flour. The in vitro gastric digestibility values of reconstituted quinoa proteinenriched flour are shown in Figure 6.7A. The profile of this figure is qualitative similar as was obtained with pure protein and protein with starch (Figures 6.1 and 6.6), however, the initial digestion rate of the unheated suspension and the suspension heated at $60{ }^{\circ} \mathrm{C}$ is slightly higher in comparison to that obtained with only starch.

It is interesting that the digestion rate and the $\mathrm{DH}$ after $180 \mathrm{~min}$ are clearly higher for the suspension preheated at $120^{\circ} \mathrm{C}$, compared to what was obtained with only protein and starch. This indicates that the effect of starch on the protein digestibility significantly decreases when fibre is present as well. We suggest that the fibre may partly prevent the interactions between protein and starch. Besides, is important to consider that fibre prevents the starch to be fully hydrated, which will increase the gelatinisation temperature of the starch too much higher temperatures. Thus the inhibiting effect of starch on the protein digestibility is partly counteracted. However, the suspensions heated at $120^{\circ} \mathrm{C}$ still present lower DH values than the only the protein (Figure 6.1), which indicates that the effect of starch is counteracted only partially. Numerous studies have explored the effects of fibre on protein digestion by measuring the degree of nitrogen loss in human excretion (FAO, 1985). Likewise, some studies in pigs have shown that fibre reduces the protein digestibility (Le Goff et al., 2002; Buraczewska, 2001). According to the FAO, the reduction in the apparent digestibility of protein is typically less than $10 \%$. While of course, many more effects are important over the whole digestive tract, the effect that we found may be one of the effects that could explain this observation.

Kritchevsky (1988) indicated that fibre modifies and usually decreases the digestibility of proteins, along with lipids and certain minerals. The decrease in the digestibility might be caused by pectin and other gel-forming polysaccharides by retention of amino acids and peptides (Mosenthin et al., 1994). Other causes which may affect (decrease) the protein digestibility could be that the fibre inhibits access of enzymes to the protein matrix. The presence of fibre in a system with a limited amount of water will also limit the hydration of starch, thereby increasing the temperature of starch gelatinization, which may result in a lower 
degree of gelatinisation and therefore a reduced effect of starch on the impediment of acid and enzyme ingression into the protein matrix.
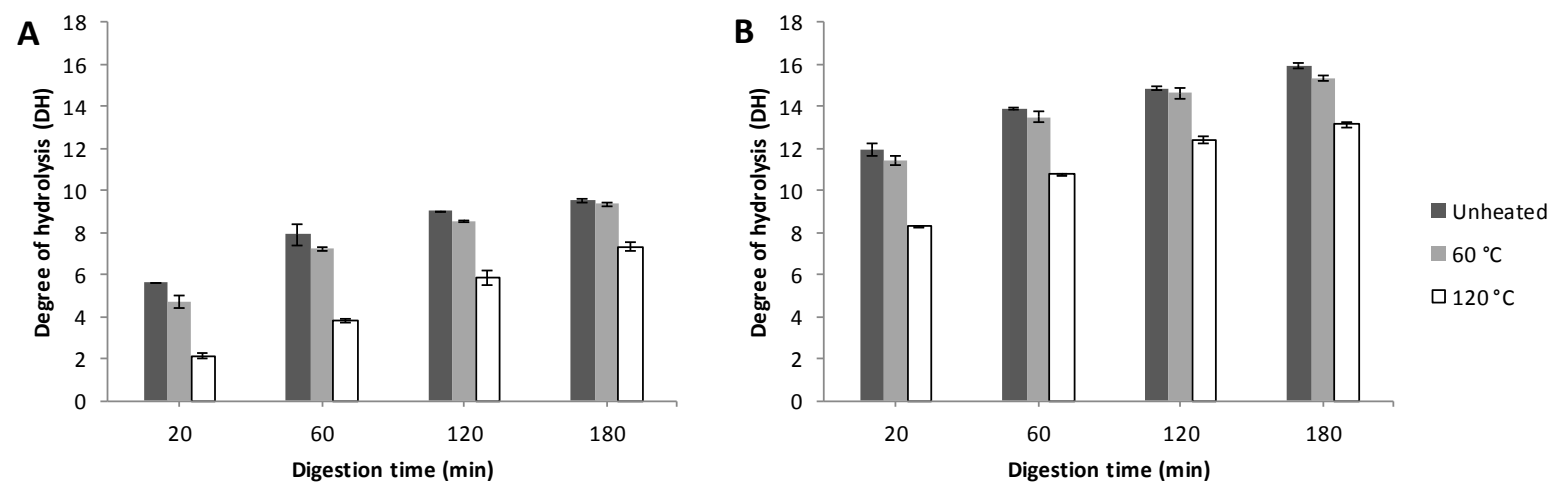

Figure 6.7. The degree of hydrolysis (DH) of unheated and heated (A) reconstituted dry fractionated quinoa flour and (B) dry fractionated suspensions quinoa during in vitro gastric digestion.

A comparison of Figure 6.7A to Fig 6.7B reveals that the reconstitution of the dry fractionated protein concentrate from the individual fraction give very different digestion dynamics. In the reconstituted concentrate, the digestion rate and the $\mathrm{DH}$ after $180^{\circ} \mathrm{C}$ are much lower, although the overall composition of both systems is the same. Apparently, the food matrix does have an effect on the digestibility; in this case the original matrix that is present in the dry fractionated concentrate is much better digestible that would be expected based on its composition. Especially the initial hydrolysis is much faster in the dry fractionated concentrate.

The chromatograms of quinoa protein-starch-fibre suspensions, which are reconstituted based on the concentration of protein-enriched flour, are shown in Figure 6.4. The protein-starch-fibre suspensions showed a greater amount of single amino acids formed in all treatments in comparison to the protein-starch suspensions (Figure 6.4), which is in agreement with the higher DH values obtained for these suspensions. The chromatograms of unheated suspensions showed a faster initial increase of peptides of different sizes $(0.2-2 \mathrm{kDa})$, but after $180 \mathrm{~min}$ of digestion, similar levels are seen as with the suspensions that were heated at $60{ }^{\circ} \mathrm{C}$. The suspensions heated at $120^{\circ} \mathrm{C}$ however yield lower levels in the MW range of $0.2-2 \mathrm{kDa}$, which indicates less peptide formation in comparison with the unheated and mildly heated (60 ${ }^{\circ} \mathrm{C}$ ) suspensions. At the same time, the suspensions heated at $120{ }^{\circ} \mathrm{C}$ give lower levels of single amino acids than the unheated and mildly heated suspensions, which is in line with the DH values. While the initial hydrolysis rate was higher for the unheated suspensions, after $180 \mathrm{~min}$ of gastric digestion, both unheated and mildly heated give similar amino acid levels and DH values. 
Surprisingly, the effect of the amount of fibre does not seem very important. Two different concentrations of fibre were added to a dispersion of $0.1 \mathrm{~g}$ of protein and $0.01 \mathrm{~g}$ of starch: $10 \%$ or $0.01 \mathrm{~g}$ fibre, and $20 \%$ or $0.02 \mathrm{~g}$ fibre. Subsequently, the dispersions were heated and then cooled to room temperature, and then subjected to in vitro gastric digestion (Figure 6.8).

The presence of fibre reduces the detrimental effect of starch on the protein digestibility when suspensions are heated, mainly at high temperature. Apparently, this effect is not dependent on fibre concentration present in the dispersion. Therefore, a small amount of fibre could be enough to partly counteract the effect of starch on the in vitro protein digestibility.

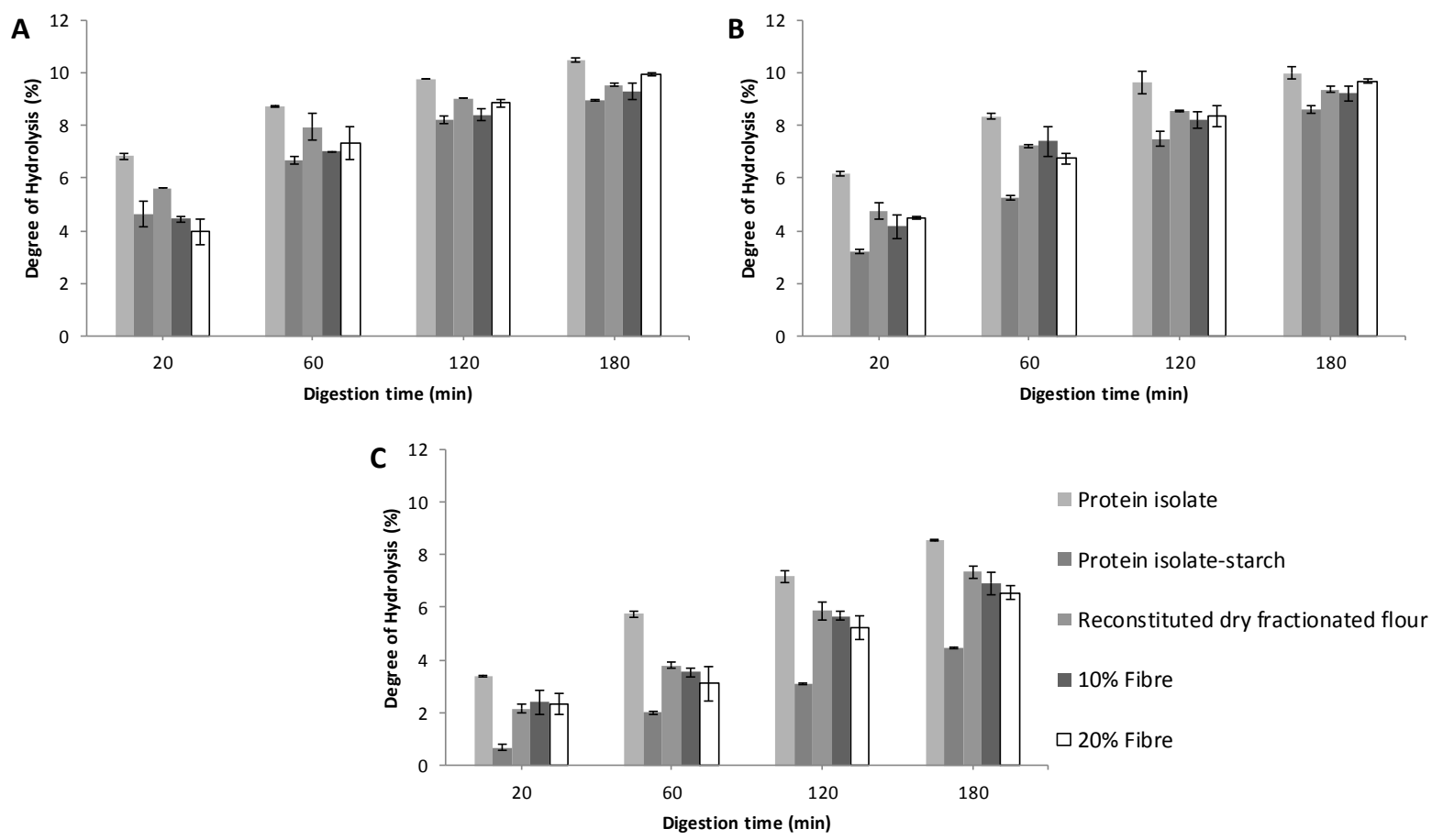

Figure 6.8. The degree of hydrolysis (DH) of (A) unheated, (B) heated at $60{ }^{\circ} \mathrm{C}$ and $(\mathrm{C})$ heated at $120{ }^{\circ} \mathrm{C}$ protein isolate, protein isolate-starch, reconstituted dry fractionated flour suspensions and reconstituted dry fractionated flour with 10 and $20 \%$ of additional fibre added during in vitro gastric digestion.

In Figure 6.9 we propose a mechanism of the effect of protein state and interaction with starch and fibre on the protein digestibility based on our results.

1. Having native protein, starch and fibre in a (dry fractionated) concentrate implies that both fibre and starch do not absorb much water. The protein, which is well soluble in this state, is well accessible to digestion. Heating this system, will denature the protein, but at the same time gelatinise the starch and hydrate the fibre, and therefore the protein aggregates will remain small, which keeps it still relatively accessible to digestion after dispersion in gastric juice. 
2. A protein that was isolated using a wet process (which implies $\mathrm{pH}$ changes and a thermal load during drying), is already partly denatured, less soluble and less accessible for digestion. Heating this protein will result in extensive aggregation and strongly lower accessibility for acid and pepsin, resulting in lower digestibility.

3. Combining the wet isolated protein with starch will result in moderate digestibility: the protein is already partly aggregated, while the starch will remove some of the water and therefore will hinder the ingression of pepsin. Heating this suspension will exacerbate this, due to extensive starch gelatinization.

4. Combining all three isolates into a reconstituted concentrate will combine the moderate digestibility of the partially denatured protein, with the hindrance of the hydrating starch and fibre. Heating this suspension will result in a dense matrix that does not allow much ingression of pepsin, while the protein is also aggregated: slow overall digestion is the result.

This interpretation predicts, that all effects are kinetic: in the end, all protein will still be digested, but the present of partially or completely hydrated starch and fibre, plus the partially or fully aggregated state of the protein, will slow the hydrolysis. It should be noted, that even after 180 min of digestion time, we still found a significant difference. Longer time scales are not relevant to gastric digestion. Thus, for all practical purposes, our interpretation implies that dry fractionated foods and foods with more or less starch and fibre will enter the duodenum in very different states. 


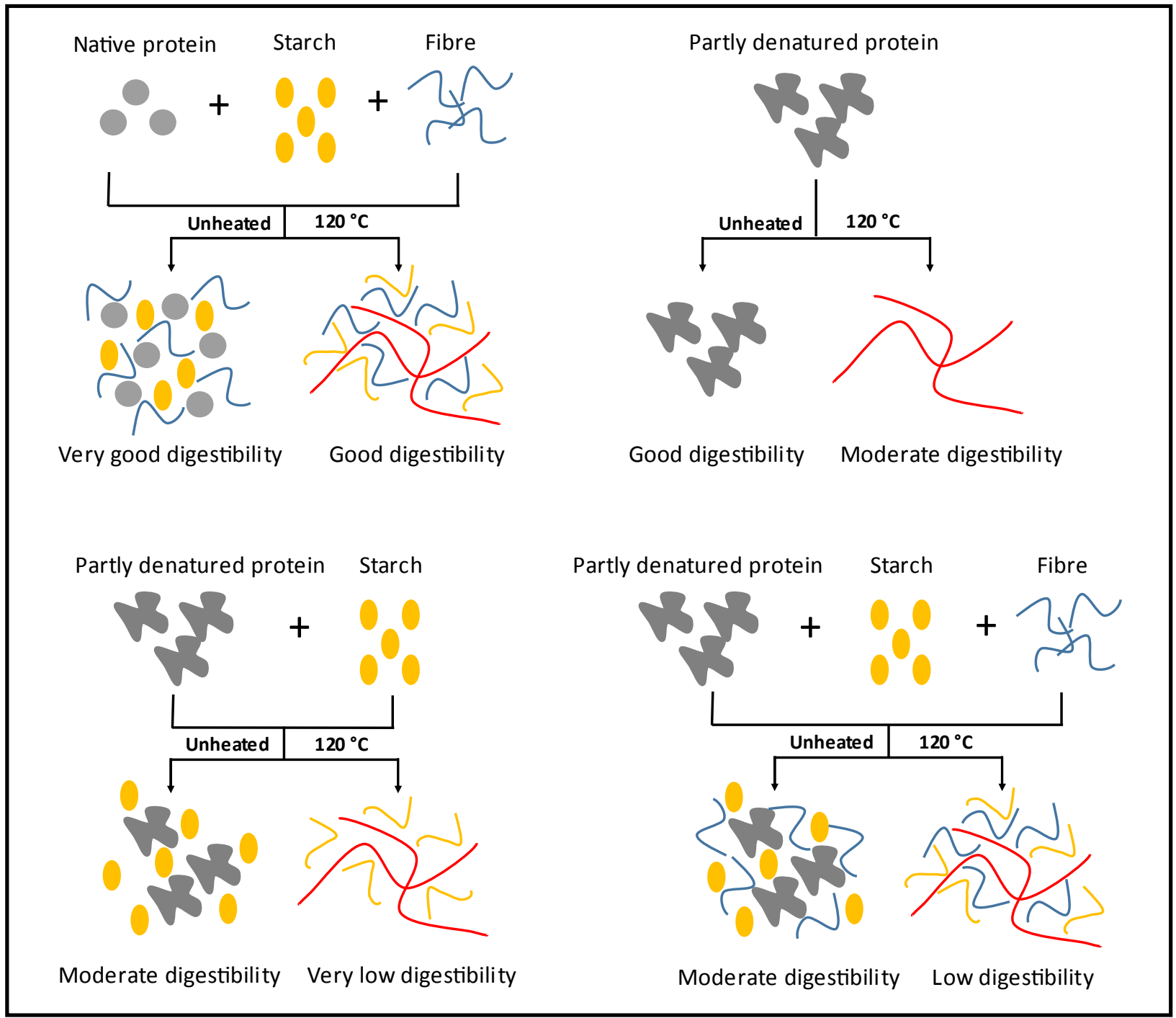

Figure 6.9. Schematic diagram of protein digestibility according to the protein state and interaction with other components after protein denaturation.

\subsection{Conclusions}

Protein digestibility is strongly influenced by the extraction method used to isolate the protein. The presence of starch and fibre reduces the digestibility of quinoa protein, which could be explained by hindrance by starch and fibre to the ingression of pepsin, reducing the rate of hydrolysis of the proteins. Starch reduces the quinoa protein digestibility more strongly than fibre. The most important finding is that the effect of starch is partially counteracted by the presence of fibre. This phenomenon is not dependent on the concentration of the fibre. Heating at $120{ }^{\circ} \mathrm{C}$ does affect the protein digestibility, which we expect is due to the formation of larger protein aggregates which are also less accessible by pepsin. 


\subsection{References}

AACC International. (1983). Method 08-01: ash-basic method (10 ${ }^{\text {th }}$ ed.), St. Paul, MN, USA: AACC International.

Abugoch, L. E. (2009). Quinoa (Chenopodium quinoa Will.): Composition, chemistry, nutritional, and functional properties. Advances in Food and Nutrition Research, 58, 131.

Avila Ruiz, G., Opazo-Navarrete, M., Meurs, M., Minor, M., Sala, G., van Boekel, M., \& Janssen, A.E.M. (2016). Denaturation and in Vitro Gastric Digestion of Heat-Treated Quinoa Protein Isolates Obtained at Various Extraction pH. Food Biophysics. 11, 184197.

Bacigalupo, A., \& Tapia, M. E. (2000). Agroindustria. In Cultivos Andinos (Ed.), Cultivos Andinos Subexplotados y Su Aporte a la Alimentacion. Santiago, Chile: Oficina Regional de La FAO para América Latina y el Caribe.

Bertoft, E. (2013). On the building block and backbone concepts of amylopectinstructure. Cereal Chemistry, 90, 294-311.

Brinegar, C., \& Goundan, S. (1993). Isolation and characterization of chenopodin, the 11S seed storage protein of quinoa (Chenopodium quinoa). Journal of Agricultural and Food Chemistry, 41(2), 182-185.

Chauhan, S., Eskin, N. A. M., \& Tkachuk, R. (1992). Nutrients and antinutrients in quinoa seeds. Cereal Chemistry, 69(1), 85-88.

Bhargava, A., Shukla, S., \& Ohri, D. (2003). Genetic variability and heritability of selected traits during different cuttings of vegetable Chenopodium. Indian Journal of Genetics and Plant Breeding, 63, 359-360.

Buraczewska, L. (2001). Fibre components negatively affect ileal protein digestibility in pigs. Journal of Animal and Feed Sciences, 10(1), 139-152.

Dalgetty, D. D., \& Baik, B. -K. (2003). Isolation and characterization of cotyledon fibers from peas, lentils, and chickpeas. Cereal Chemistry, 80(3), 310-315. 
Dini, I., Tenore, G. C., \& Dini, A. (2010). Antioxidant compound contents and antioxidant activity before and after cooking in sweet and bitter Chenopodium quinoa seeds. LWT - Food Science and Technology, 43(3), 447-451.

Dhingra, D., Michael, M., Rajput, H., \& Patil, R.T. (2012). Dietary fibre in foods: A review. Journal of Food Science and Technology, 49(3), 255-266.

Duodu, K. G., Taylora, J. R. N., Beltonb, P. S., \& Hamaker, B. R. (2003). Factors Affecting Sorghum Protein Digestibility. Journal of Cereal Science, 38(2), 117-131.

Elsohaimy, S.A., Refaay, T.M., \& Zaytoum, M.A.M. Physicochemical and functional properties of quinoa protein isolate. Annals of Agricultural Science, 60(2), 297-305.

FAO (2011). La quinua: cultivo milenario para contribuir a la seguridad alimentaria mundial. Switzerland, Geneva.

FAO (1985). Energy and protein requirements. Switzerland, Geneva.

Fisher, S., Wilckens, R., Jara, J., Aranda, M., Valdivia, W., Bustamante, L., Graf, F., \& Obal, I. (2017). Protein and antioxidant composition of quinoa (Chenopodium quinoa Willd.) sprout from seeds submitted to water stress, salinity and light conditions. Industrial Crops \& Products, 107, 558-564.

Gómez-Caravaca, A. M., Iafelice, G., Verardo, V., Marconi, E., \& Caboni, M. F. (2014). Influence of pearling process on phenolic and saponin content in quinoa (Chenopodium quinoa Willd). Food Chemistry, 157, 174-178.

Kaspchak, E., Schüler, M.A., Fogagnoli, S., Cavicchiolo, C.R., Meira, J.L., Mafra, M.R., \& Igarashi-Mafra, L. (2017). Determination of heat-set gelation capacity of a quinoa protein isolate (Chenopodium quinoa) by dynamic oscillatory rheological analysis. Food Chemistry, 232, 263-271.

Koziol, M. (1992). Chemical composition and nutritional evaluation of quinoa (Chenopodium quinoa Willd.). Journal of Food Composition and Analysis, 5(1), 35-68.

Kritchevsky, D. (1988). Dietary fiber. Annual Review of Nutrition, 8, 301-328. 
Lattimer, J.M., \& Haub, M.D. (2010). Effects of Dietary Fiber and Its Components on Metabolic Health. Nutrients, 2, 1266-1289.

Le, Goff, G., van Milgen, J. \& Noblet, J. (2002). Influence of dietary fibre on digestive utilization and rate of passage in growing pigs, finishing pigs and adult sows. Animal Science, 74, 503-515.

Li, G., \& Zhu, F. (2017). Physicochemical properties of quinoa flour as affected by starch interactions. Food Chemistry, 221, 1560-1568.

Lindeboom, N., Chang, P.R., Falk, K.C., \& Tyler, R.T. (2005). Characteristics of starch from eight quinoa lines. Cereal Chemistry, 82, 216-222.

López-Barón, N., Gu, Y., Vasanthan, T., \& Hoover, R. (2017). Plant proteins mitigate in vitro wheat starch digestibility. Food Hydrocolloids, 69, 19-27.

Lorenz, K. (1990). Quinoa (Chenopodium quinoa) starch - Physico-chemicalproperties and functional characteristics. Starch-Stärke, 42, 81-86.

Mosenthin, R., Sauer, W.C., \& Ahrens, F., (1994). Dietary pectin's effect on ileal and fecal amino acid digestibility and exocrine pancreatic secretions in growing pigs. Journal of Nutrition, 124, 1222-1229.

Navarro-Lisboa, R., Herrera, C., Zúñiga, R.N., Enrione, J., Guzmán, F., Matiacevich, S., \& Astudillo-Castro, C. (2017). Quinoa proteins (Chenopodium quinoa Willd.) fractionated by ultrafiltration using ceramic membranes: The role of $\mathrm{pH}$ on physicochemical and conformational properties. Food and Bioproducts Processing, 102, 20-30.

Navruz-Varli, S., \& Sanlier, N. (2016). Nutritional and health benefits of quinoa (Chenopodium quinoa Willd.). Journal of Cereal Science, 69, 371-376.

Neucere, N. J., \& Ory, R. L. (1968). Effect of organic on the proteins extracted from peanuts. Journal of Agricultural and Food Chemistry, 16(2), 364-365.

Opazo-Navarrete, M., Tagle, D., Boom, R.M., Janssen, A.E.M., Schutyser, M.A.I. (2018). Dry fractionation od quinoa sweet varieties Atlas and Riobamba for sustainable production of protein and starch fractions. Chapter 5, this thesis. 
Opazo-Navarrete, M., Schutyser, M. A. I., Boom, R. M., \& Janssen, A. E. M. (2017). Effect of pre-treatment on in vitro gastric digestion of quinoa protein (Chenopodium quinoa Willd.) obtained by wet and dry fractionation. International Journal of Food Sciences and Nutrition, 31, 1-11.

Pushparaj, F. S., \& Urooj, A. (2011). Influence of processing on dietary fiber, tannin and in vitro protein digestibility of pearl millet. Food and Nutrition Sciences, 2, 895-900.

Ruales, J., \& Nair, B. M. (1994). Properties of starch and dietary fibre in raw and processed quinoa (Chenopodium quinoa Willd.) seeds. Plant Foods for Human Nutrition, 45, 223 246.

Ruales, J., \& Nair, B. M. (1992). Nutritional quality of the protein in quinoa (Chenopodium quinoa Willd) seeds. Plants Food for Human Nutrition, 42(1), 1-11.

Sagum, R., \& Arcot, J. (2000). Effect of domestic processing methods on the starch, non-starch polysaccharides and in vitro starch and protein digestibility of three varieties of rice with varying levels of amylose. Food Chemistry, 70(1), 107-111.

Schutyser, M.A.I., \& van der Goot, A.J. (2011). The potential of dry fractionation processes for sustainable plant protein production, Trends in Food Science \& Technology, 22, 154164.

Steffolani, M. E., León, A. E., \& Pérez, G. T. (2013). Study of the physicochemical and functional characterization of quinoa and kañiwa starches. Starch-Stärke, 65,976-983.

Wong, J.H., Lau, T., Cai, N., Singh, J., Pedersen. J.F., Vensel, W.H., Hurkman, W.L., Wilson, J.D., Lemaux, P.G., \& Buchanan, B. (2009). Digestibility of protein and starch from sorghum (Sorghum bicolor) is linked to biochemical and structural features of grain endosperm. Journal of Cereal Science, 49, 73-82. 


\section{Chapter 7}

In vitro protein gastric digestibility of soy and pea proteins in relation to their aggregation behaviour

This chapter has been submitted as: Opazo-Navarrete, M., Rivera del Rio, A., Boom, R.M. \& Janssen, A.E.M. In vitro gastric digestibility of soy and pea proteins in relation to their aggregation behaviour. 


\subsection{Abstract}

Processing of food proteins may alter the protein aggregation properties and the digestibility. In this study we analysed the relationship between the aggregate formation and in vitro gastric digestibility of soy and pea proteins, comparing unheated and heated commercial soy and pea protein dispersions. Full dispersions were separated into a soluble (supernatant) and an insoluble fraction (pellet) to study the specific effect of heat-induced aggregation on the digestibility. The solubility of proteins is not always a prerequisite for protein digestion, but samples containing heat-induced aggregates are less digestible than their soluble counterparts. Heat-treatment did not impact digestibility of SPI full dispersions, while this increased in PPC heated at $120{ }^{\circ} \mathrm{C}$. In conclusion, protein aggregation affects the soluble and insoluble proteins differently. 


\subsection{Introduction}

The current demand for animal-sourced food products has strained our natural resources to unsustainable levels. The design of novel food structures from plant proteins has allowed the development of appealing and more sustainable foods (Elkington, 1994).

Legumes like soybean (Glycine max L.) and pea (Pisum sativum L.) are important economic sources of protein in the diet of many developed and developing countries (Nielsen, 1991). Soybean has a high protein content (40\%) and is often used for replacing meat or milk, while pea provides a locally sourced, non-allergenic, non-GMO alternative for European markets. These proteins are available to the food industry mainly as flours, concentrates and isolates. The functionality of leguminous proteins makes these proteins attractive for the food industry. Gelation, emulsification capacity and stability are maximized with optimal protein hydration (Egbert \& Payne, 2009), which is commonly achieved by heat treatment, however, the degree of denaturation determines the potential functionality of a protein ingredient.

Nowadays, the quality of dietary proteins is evaluated considering both the amino acid profile and the presence of essential amino acids. However, before these proteins can be digested, they need to be hydrolyzed into small peptides and single amino acids, which are subsequently absorbed. Therefore, bio-accessibility and bio-availability are just as important in assessing the nutritional quality of proteins.

Low digestibility and poor availability of some essential amino acids limit the utilisation of legume proteins. The low digestibility is attributed to many factors, including the presence of anti-nutritional factors (e.g. protease inhibitors, lectins, phytates, and polyphenols), the structure and conformation of the proteins, and interactions of the proteins with other seed components (Tang et al., 2009; Nielsen, 1991). Heat treatment has been widely used to improve the nutritional value of pulse and legume proteins (Frikha et al., 2013; Wang et al., 2009). The obtained improvement has been attributed to the inactivation of anti-nutritional factors; but how the mechanism of heating influences the digestibility is still unclear.

Protein digestion begins in the stomach where pepsin cleaves proteins into a mixture of oligopeptides. In the stomach, hydrochloric acid $(\mathrm{HCl})$ is secreted to inactivate potential pathogens, and to improve the digestibility of dietary proteins by denaturing them. Pepsin is an endopeptidase with a preference for cleavage of peptide bonds involving amino acids with hydrophobic side chains (Bhagavan, 2002). Protein digestion later continues in the small 
intestine where trypsin, chymotrypsin and peptidases hydrolyse the protein fragments into small peptides and amino acids.

Instruments for assessing the bioaccessibility of dietary proteins by the human digestive system are in vitro assays that mimic physiological conditions, e.g. $\mathrm{pH}$, temperature, enzyme composition and concentration, among others. Several methods are described in the literature with different scopes and aims of the research. A wide array of testing conditions, models and equipment have been designed with the purpose of better understanding the dynamics of human digestion.

The conformational state of the protein and the modification of individual amino acids during processing can impact its digestibility and ultimately its bioaccessibility (Levesque, 2015). In vitro assays have demonstrated the effect of processing and structure on protein digestibility. For instance, high hydrostatic pressure can reduce the effect of antinutritional factors and enhance protein digestibility in peas and beans (Linsberger-Martin et al., 2013). Malting can improve amaranth protein digestibility (Hejazi et al., 2016). Conversely, extended toasting times have a negative effect on the rate of protein hydrolysis of rapeseed meal (Salazar-Villanea et al., 2017), and matrices formed with a prior heat treatment such as whey protein isolate gels hinder the diffusion of pepsin and limit its hydrolytic activity (Luo et al., 2017).

Ruiz et al. (2016) determined that the in vitro gastric digestibility of quinoa protein extracts was reduced upon heating. It was later proposed that the cause of this was the formation of aggregates (Opazo-Navarrete et al., 2017). Similar results were obtained with lupine concentrates from dry fractionation, for which heated and aggregated protein released a lower amount of small peptides compared to native and moderately heated proteins (Pelgrom et al., 2014). In contrast, heat-induced aggregation of ovalbumin found improved the digestibility relative to native proteins (Gerrard et al., 2012). The relevance of the type of microstructure on the digestibility was demonstrated: linear aggregates were better digestible than spherical. The overall improved digestibility of ovalbumin upon heat treatment was attributed to the surface area-to-volume ratio that made peptide bonds better accessible for digestive proteases (Nyemb et al., 2014).

Our present study explores the relationship between the aggregate formation and in vitro digestion; we focus on the gastric digestion of solutions of soy and pea proteins. 


\subsection{Materials and methods}

\subsubsection{Materials}

Soy protein isolate (SPI) (SUPRO® 500E IP) with a protein content of $83.4 \mathrm{dw} \%$ was purchased from Solae (St. Louis, Missouri, USA). Pea protein concentrate (PPC) (NUTRALYS® F85G) was acquired from Roquette (Lestrem, France) and had a protein content of $75 \mathrm{dw} \%$. The protein content was measured by Dumas analysis (Nitrogen analyser, FlashEA 1112 series, Thermo Scientific, Interscience, Breda, The Netherlands) in triplicate. The conversion factor of SPI used was 5.71, while the conversion factor of PPC was 5.52. Pepsin from porcine gastric mucosa (P7125) and all other chemicals were purchased from Sigma-Aldrich, Inc. (St. Louis, MO, U.S.A.). Milli-Q water $\left(18.2 \mathrm{M} \Omega \mathrm{cm}\right.$ at $25^{\circ} \mathrm{C}$, Millipore Corporation, Molsheim, France) was used for all experiments.

\subsubsection{Material preparation}

SPI and PPC were used to prepare $5 \mathrm{dw} \%$ protein dispersions according to Figure 7.1. The required amount was mixed with Milli-Q water at room temperature for $30 \mathrm{~min}$, at $700 \mathrm{rpm}$ and allowed to hydrate overnight. Samples were heated in 2 ml-Eppendorf tubes to 60 and $90{ }^{\circ} \mathrm{C}$ for $30 \mathrm{~min}$ in a Thermomixer (Eppendorf AG, Hamburg, Germany) at $800 \mathrm{rpm}$. Samples that were heated to $120^{\circ} \mathrm{C}$ were heated in a dry heating block (Grant QBT4, Cambridge, UK) and vortexed every $5 \mathrm{~min}$ to simulate thermomixer-heating. To separate the soluble from the insoluble materials, samples were centrifuged at 5,000 rpm for $30 \mathrm{~min}$.

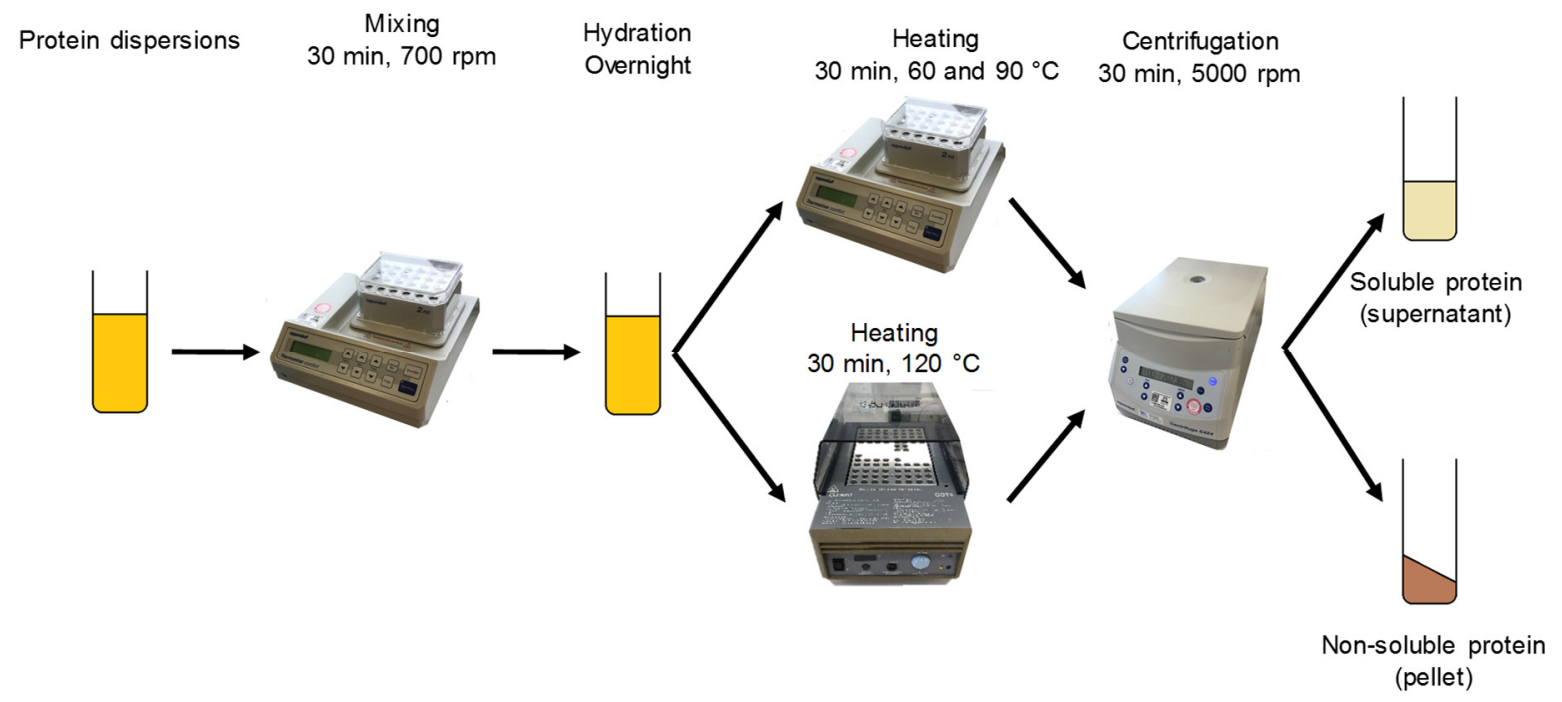

Figure 7.1. Schematic overview of material preparation. 


\subsubsection{Protein determination, solubility}

Pierce $^{\mathrm{TM}}$ Bicinchoninic acid (BCA) protein assay kit (ThermoFisher Scientific Inc., USA) was used to quantify the amount of protein. A standard of bovine serum albumin (BSA) (ThermoFisher Scientific Inc., USA) was used to prepare a standard curve. Samples were diluted to estimated concentrations within the standard curve of $20-2000 \mu \mathrm{g} / \mathrm{ml} \mathrm{BSA}$. The method followed the standard protocol, incubating the reacting samples for $30 \mathrm{~min}$ at $37{ }^{\circ} \mathrm{C}$, with the prepared reagent. The resulting absorbance of the colourimetric reaction was measured at $562 \mathrm{~nm}$. Solubility was calculated according to the Equation 7.1. Protein concentration and solubility determinations were conducted in triplicate.

Protein solubility $(\%)=\frac{g \text { protein }_{\text {supernatant }}}{g \text { total powder }} \cdot 100$

Equation 7.1

\subsubsection{Particle size distribution}

Static light diffraction was used to determine the particle size distribution using a Mastersizer 2000 (Malvern Instruments Ltd., Worcestershire, UK) equipped with a wet module unit (Hydro $2000 \mathrm{MU})$. Once the sample volume reached an obscuration rate between 10 and $20 \%$, the diluted sample was stirred at 1,200 rpm. The measurements were conducted assuming a refractive index of 1.45 and 1.33 for the dispersed and continuous phase, respectively. The particle size distribution was reported as volume equivalent sphere diameter. All samples were measured in triplicate.

\subsubsection{Light microscopy}

Particle morphology was observed using a light microscopy (Axio Scope A1, Carl Zeiss Microscopy GmbH, Gottingen, Germany) equipped with a LED lamp. The images were captured by the connected video camera (Axio Cam MRc5, Carl Zeiss Meditec, Germany) and acquisition software Zeiss AxioVision Rel 4.8. Images were acquired with a 40x objective.

\subsubsection{Sodium dodecyl sulphate polyacrylamide gel electrophoresis (SDS-PAGE)}

The characterisation of the protein in the dispersions was done by non-reducing and reducing SDS-PAGE electrophoresis. The samples were diluted with sample buffer $(0.5 \mathrm{M}$ Tris- $\mathrm{HCl}$, $\mathrm{pH}$ 6.8; 2 wt\% SDS; 2.5 wt\% glycerol; 0.2 wt\% bromophenol blue) with 0.5 wt\% 2mercaptoethanol for the reducing conditions. The weight ratio of sample-to-buffer was 1:1. Each sample was heated to $90{ }^{\circ} \mathrm{C}$ for 4 min in an Eppendorf thermomixer (Eppendorf $\mathrm{AG}$, 
Hamburg, Germany) and mixing at $800 \mathrm{rpm}$. The cooled samples were then centrifuged at $13,000 \mathrm{~g}$ for $3 \mathrm{~min}$. An amount of $10 \mu \mathrm{L}$ of the supernatant each sample and molecular weight markers Precision Plus Protein All Blue Standards (Bio-Rad Laboratories Inc., Hercules, USA) were loaded on a 12\% Tris-HCl Mini-PROTEAN TGX Precast Gel (Bio-Rad Laboratories Inc., USA). The electrophoresis was carried out at $200 \mathrm{~V}$. Afterwards, the gel was stained with Biosafe Coomassie Stain (Bio-Rad Laboratories Inc., USA) and gel images were taken using a GS900 Calibrated Densitometry System (Bio-Rad Laboratories, Inc., USA).

\subsubsection{In vitro gastric digestion}

Simulated gastric fluid (SGF) was prepared according to Opazo-Navarrete et al. (2017) with minor modifications. For this, pepsin $(1 \mathrm{~g} / \mathrm{L})$ and $\mathrm{NaCl}(8.775 \mathrm{~g} / \mathrm{L})$ were dissolved in Milli-Q water and $2 \mathrm{M} \mathrm{HCl}$ was used to adjust the $\mathrm{pH}$ to 2.0. The SGF was transferred to a jacketed glass vessel connected to a water bath at $37{ }^{\circ} \mathrm{C}$ (Julabo $\mathrm{GmbH}$, Seelbach, Germany) for $3 \mathrm{~h}$. The protein samples (substrate) were added to the SGF to an enzyme to substrate ratio of 1:2. The samples were stirred at $100 \mathrm{rpm}$ in a vessel sealed with Parafilm (Pechiney Plastic Packaging, Inc., IL, U.S.A.) to avoid evaporation.

All assays started with 5\% soy and pea proteins dispersions. Unheated dispersions were compared to heated dispersions at 90 and $120{ }^{\circ} \mathrm{C}$ for $30 \mathrm{~min}$. Full dispersions were centrifugeseparated into a soluble (supernatant) and an insoluble fraction (pellet). Digestion assays were conducted such, that the full dispersion, pellet or supernatant were put into SGF. The enzymeto-substrate ratio was maintained constant regardless of the treatment or fraction under digestion.

Samples were taken at 20,60 and 120 min for further analyses. Immediately after sampling, the samples were heated in a pre-heated Eppendorf thermomixer (Eppendorf AG, Hamburg, Germany) at $90{ }^{\circ} \mathrm{C}$ and 1,400 rpm for $5 \mathrm{~min}$ to inactivate pepsin, which is rapidly inactivated at a temperature above $62{ }^{\circ} \mathrm{C}$ (Casey \& Laidler, 1951). All digestion experiments were done in triplicate.

\subsubsection{OPA method}

The degree of hydrolysis (DH) was measured by using the OPA method in order to determine the degree of hydrolysis attained. The OPA reagent was prepared by dissolving $3.81 \mathrm{~g}$ sodium tetraborate decahydrate (Borax) and $0.1 \mathrm{~g}$ of sodium dodecyl sulfate (SDS) in $80 \mathrm{~mL}$ milli-Q 
water. o-Phthaldialdehyde (OPA), $80 \mathrm{mg}$ was dissolved in $2 \mathrm{~mL}$ ethanol, then was added to the Borax-SDS solution together with $88 \mathrm{mg}$ of dithiothreitol (DTT). The solution was filled up to $100 \mathrm{~mL}$ with milli-Q water and filtered through a $0.45 \mu \mathrm{m}$ filter. The solution was stored in a bottle covered with aluminium foil because OPA reagent is sensitive to light.

A standard curve was prepared using L-serine (Alfa Aesar, Germany) in a concentration range of $50-200 \mathrm{mg} / \mathrm{L}$. The OPA assay was carried out by the addition of $200 \mu \mathrm{L}$ of sample (or standard) to $1.5 \mathrm{~mL}$ of OPA reagent and was measured after 3 minutes at $340 \mathrm{~nm}$ with a spectrophotometer DU 720 (Beckman Coulter Inc. Pasadena, CA, U.S.A). The absorbance values were converted to free amino groups $(\mathrm{mmol} / \mathrm{l})$ from a standard curve. Free amino groups values from digestion samples were corrected by subtracting the contribution of free amino groups from SGF. Free amino groups were expressed as serine amino equivalents (Serine $\mathrm{NH}_{2}$ ), then $\mathrm{DH}$ values were calculated with the following equations:

$$
\begin{aligned}
& D H=\frac{h}{h_{t o t}} \cdot 100 \\
& h=\frac{\left(\text { Serine } \mathrm{NH}_{2}-\beta\right)}{\alpha}
\end{aligned}
$$

where $\beta$ was 0.342 and $\alpha$ equal 0.97 for soy and $\beta$ was 0.4 and $\alpha$ equal 1 for pea (Adler-Nissen, 1986). The $h_{\text {tot }}$ was estimated according to the concentration of each amino acid present in the protein and found to be $7.8 \mathrm{mequv} / \mathrm{g}$ for soy protein and $7.4 \mathrm{mequv} / \mathrm{g}$ for pea protein. All measurements were done in triplicate.

\subsubsection{Size exclusion chromatography (HPSEC)}

In vitro digested samples were analyzed via high performance size exclusion chromatography (HPSEC) using an Ultimate 3000 UHPLC system (Thermo Scientific, MA, U.S.A.) equipped with a TSKgel G3000SWxl column (7.8 mm x 300 mm) (Tosoh Bioscience LLC, PA, U.S.A.) and TSKgel G2000SWxl (7.8 mm x 300 mm) (Tosoh Bioscience LLC, PA, U.S.A.) connected in line. For analysis, $10 \mu \mathrm{L}$ of undiluted sample was used. The mobile phase was acetonitrile (30\%) in Milli-Q water (70\%) buffer containing trifluoroacetic acid $(0.1 \%)$. The flow rate was $1.5 \mathrm{~mL} / \mathrm{min}$ and the UV detector was set at $214 \mathrm{~nm}$. Calibration was done with: thyroglobulin (670 kDa), g-globulin (158 kDa), ovalbumin (44.3 kDa), $\alpha$-lactalbumin (14.1 kDa), aprotinin $(6.51 \mathrm{kDa})$, insulin $(5.7 \mathrm{kDa})$, bacitracin $(1.42 \mathrm{kDa})$ and phenylalanine (165 Da) (Sigma- 
Aldrich, Inc., St. Louis, MO, U.S.A.). The molecular mass was estimated based on the elution time of molecular weights markers. All measurements were done in duplicate.

\subsubsection{Statistical analysis}

Fisher's least significant difference (LSD) test was used for testing and the differences were taken to be statistically significant when the $\mathrm{p}$-value was $\mathrm{p}<0.05$. The multiple range test (MRT) included was used to prove the existence of homogeneous groups within each of the parameters analysed. All analysis was performed using Statgraphics Centurion XVI Statistical Software (Statistical Graphics Corp., Herdon, USA).

\subsection{RESULTS AND DISCUSSION}

\subsubsection{Heat-induced aggregates}

Unheated protein dispersions exhibited capsule-like structures with some variation in shape and size (Figure A7.1). This can be attributed to the spray drying step at the end of the production of commercial protein isolates and concentrates. While the exact production process used by the manufacturer is unknown, it is likely that maltodextrin is used to ensure optimum spray drying conditions (Syll et al., 2013). The maltodextrin would form the outer wall of the capsules in powder form and in aqueous dispersion. Rocha et al. (2009) and Favaro-Trindade et al. (2010) also noted the presence of such structures when spray drying casein hydrolysate using maltodextrins and mixtures of gelatine and isolated soy protein, respectively.

Figure 7.2 shows the particle size distribution of aqueous unheated and heated SPI and PPC dispersions at different temperatures. Smaller particles were observed in PPC dispersions as compared to SPI, for both unheated and heated dispersions. However, after heating at $60{ }^{\circ} \mathrm{C}$, both SPI and PPC dispersions showed smaller particles with smaller size distribution. Even smaller particles ranging from 4 to $40 \mu \mathrm{m}$ were observed for the dispersions heated at $90{ }^{\circ} \mathrm{C}$ for 30 min. The most significant changes were observed at $120{ }^{\circ} \mathrm{C}$, which yields a very wide distribution. 

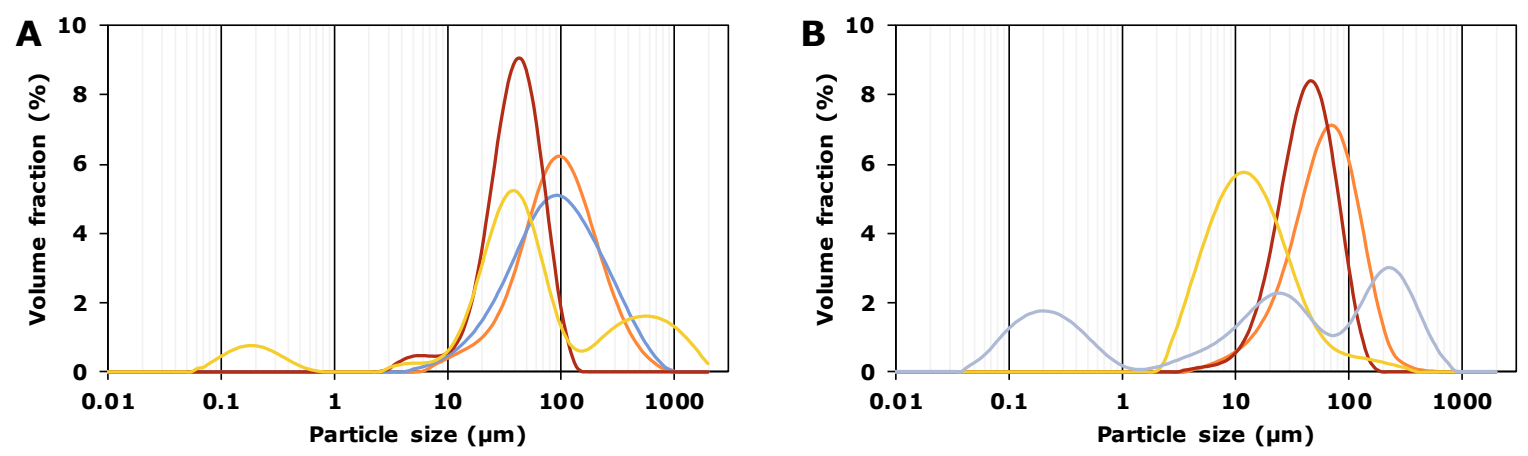

Figure 7.2. Particle size distribution of (A) SPI and (B) PPC in unheated (orange) and heated at $60{ }^{\circ} \mathrm{C}$ (red), 90 ${ }^{\circ} \mathrm{C}$ (yellow) and $120^{\circ} \mathrm{C}$ (blue) dispersions for $30 \mathrm{~min}$ (average of three consecutive measurements).

The denaturation temperature $\left(T_{d}\right)$ of soy is $77^{\circ} \mathrm{C}$ and $94{ }^{\circ} \mathrm{C}$ for $\beta$-conglycinin and glycinin (Tang et al., 2007), respectively, while for pea protein this is around $88{ }^{\circ} \mathrm{C}$ (Mession et al., 2012). Therefore, changes occurring at $60{ }^{\circ} \mathrm{C}$ should not be attributed to a significant conformational change caused by heat treatment as unfolding is reversible upon cooling below $T_{d}$

Some capsules remained in the dispersions heated at $90{ }^{\circ} \mathrm{C}$. In addition, a new, more disordered structure was observed in these samples, most likely denatured proteins, released from the broken encapsulates. Hydrophobic interactions gave rise to some degree of aggregation. Random association of these primary aggregates results in the large particles observed on the upper side of the particle size spectrum of 90 and $120{ }^{\circ} \mathrm{C}$ heated samples. In summary, for the $90{ }^{\circ} \mathrm{C}$ treatment, we observed small primary aggregates, remaining encapsulates and large agglomerates. Medium and larger aggregates were observed for $120{ }^{\circ} \mathrm{C}$, in addition to some smaller particles that were detected by laser diffraction.

From a practical, experimental standpoint, some of the large aggregates that were formed may be too large to be accurately detected with light diffraction $(2 \mathrm{~mm})$. The microscopic observations reveal the irregular morphology of the largest agglomerates.

\subsubsection{Effect of heating on molecular weight distribution}

The results of reducing and non-reducing SDS-PAGE analysis of unheated and heated SPI and PPC dispersions are presented in Figure 7.3 (A and B).

Under non-reducing conditions, SPI shows polypeptides that are associated with the major globulin fractions of $\beta$-conglycin (7S), while under non-reducing conditions, globulin fractions of $\beta$-conglycin (7S) and glycinin (11S) are observed (Figure 7.3A). Non-reducing conditions 
yield bands above $100 \mathrm{kDa}$ which are not observed under reducing conditions, which indicates the presence of disulphide bonds. Li et al. (2007) reported that the formation of these high molecular weight constituents implies covalent and non-covalent interactions between $\alpha$ and $\alpha$ ' subunits of $\beta$-conglycinin and of A and B glycinin. The glycinin in SPI did not denature at 90 ${ }^{\circ} \mathrm{C}$. As expected, the most significant change is seen for dispersions heated at $120{ }^{\circ} \mathrm{C}$. The same bands are visible as with other temperatures, but only faded in comparison with the other samples, indicating that most protein has aggregated in large agglomerates and hence is not observed with SDS-PAGE.

Figure 7.3B shows the results for PPC. Under non-reducing conditions, the pea proteins fragment into multiple components with a molecular weight ranging from $126.1 \mathrm{kDa}$ to $10 \mathrm{kDa}$, which originate mainly from vicilin and legumin. Under reducing conditions, subunits of convicilin, vicilin and legumin can be identified: one can see multiple components with a molecular weight (MW) ranging from $99.4 \mathrm{kDa}$ to $10 \mathrm{kDa}$. Heating at 60 and $90{ }^{\circ} \mathrm{C}$ does not cause changes that are detectable by SDS-PAGE, but heating at $120{ }^{\circ} \mathrm{C}$ bands become faded, just as with SPC.

Finally, in both SPI and PPC samples, one can see a band at around $90 \mathrm{kDa}$, which corresponds to lipoxygenases (Shand et al., 2007). This lipoxygenase is an iron-containing enzyme that catalyses the oxidation of unsaturated fatty acids (Veronica \& Mitsuo, 2011). The enzyme was observed in the unheated and heated soy and pea protein dispersions: the heat treatment does not seem to affect the lipoxygenase in both protein sources. 


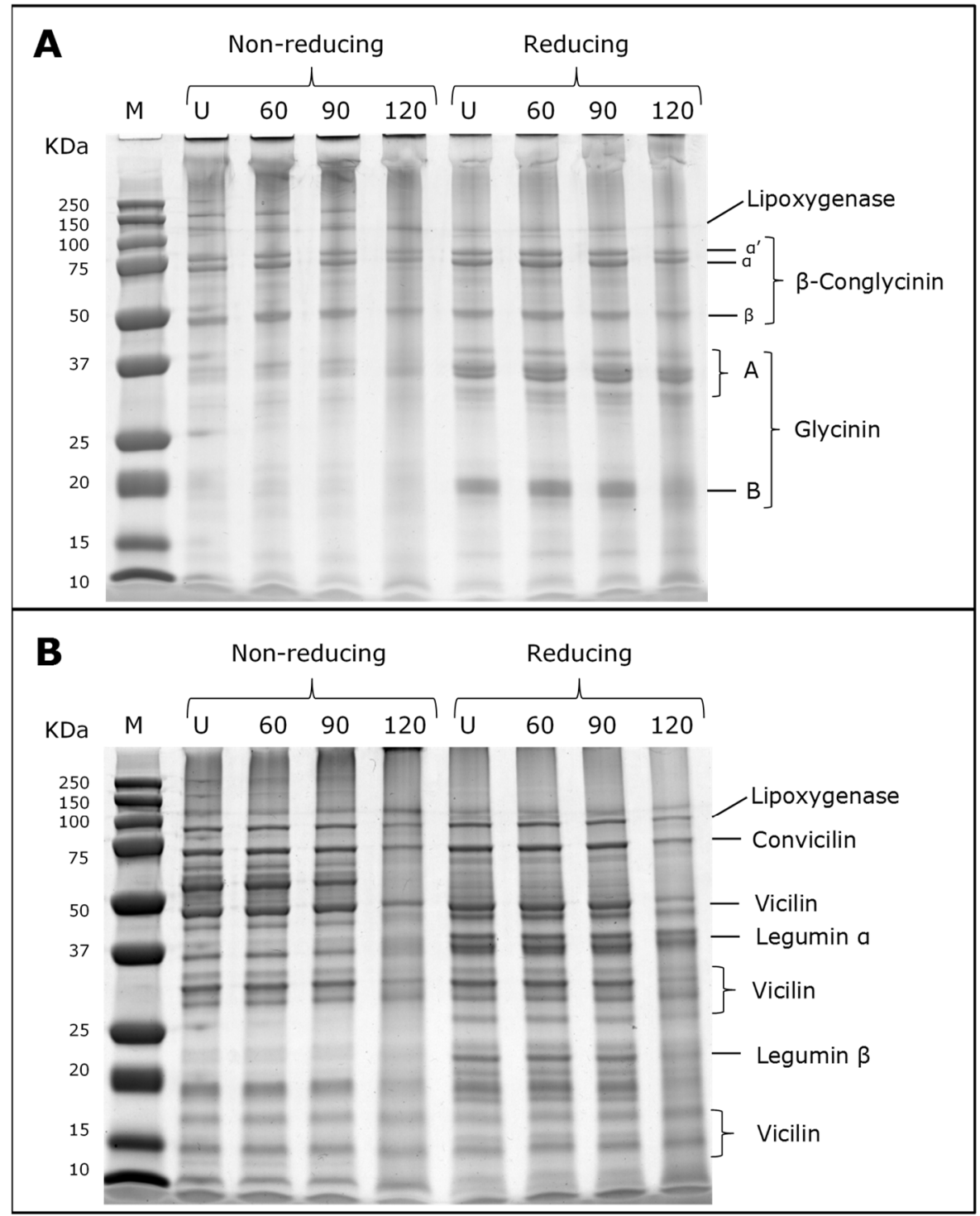

Figure 7.3. SDS-PAGE patterns of unheated (U) and heated at 60,90 and $120^{\circ} \mathrm{C}$ full dispersions of (A) SPI and (B) PPC under reducing and non-reducing conditions.

The SDS-PAGE results show that at least part of the proteins in SPC and PPC dispersions are not aggregated, and could be analysed with this method. No clear evidence of aggregation can be found with the non-reducing SDS-PAGE analysis of full dispersions. Heat-induced aggregates are present in heated dispersions, most of the proteins present in the dispersion are not aggregated. It is interesting to see that the primary protein structure is not affected at $90{ }^{\circ} \mathrm{C}$, both in SPI and PPC. In fact, the denaturation temperatures of glycinin range from 83 to $92{ }^{\circ} \mathrm{C}$ (Petruccelli \& Añón, 1996), while the denaturation temperature of $\beta$-conglycinin fraction is around $73{ }^{\circ} \mathrm{C}$. This implies that a part of glycinin and $\beta$-conglycinin proteins may remain undissociated in the dispersion after heat treatment for $30 \mathrm{~min}$ at 90 and $120{ }^{\circ} \mathrm{C}$. 


\subsubsection{Separation of large and medium size from small particles}

We centrifuged the dispersions to separate the larger agglomerates from the small primary aggregates (procedure as visualised in Figure 7.1). Figure 7.4 presents the typical particle sizes obtained. The separation is good in dispersions that shows broad particle size distributions. We also found good separation for dispersions in which originally only medium-sized particles were observed. This may be due to the particles being in loose association, and therefore the light diffraction was not able to distinguish the different types. However, during centrifugation, these loose associations fall apart, and thus the aggregates can be separated.

A

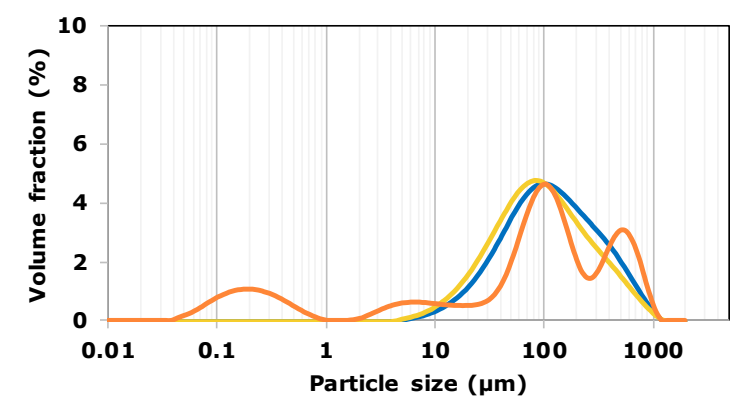

B

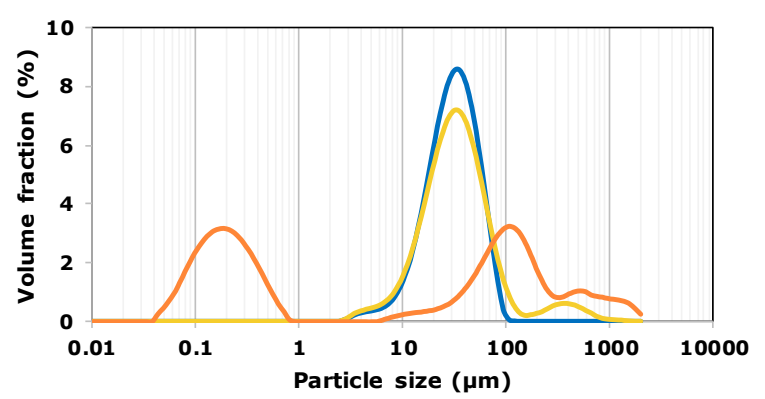

C

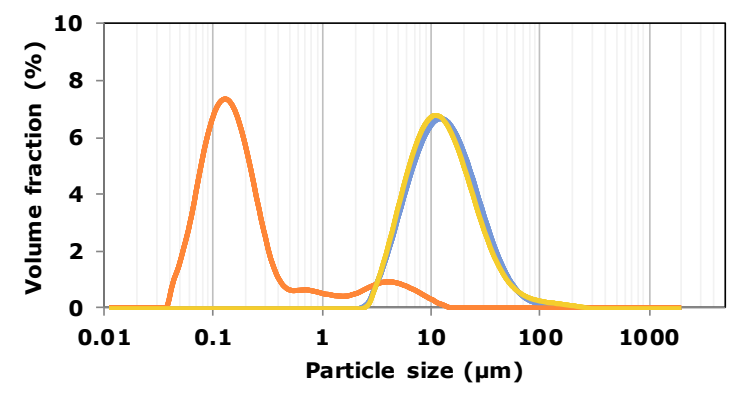

D

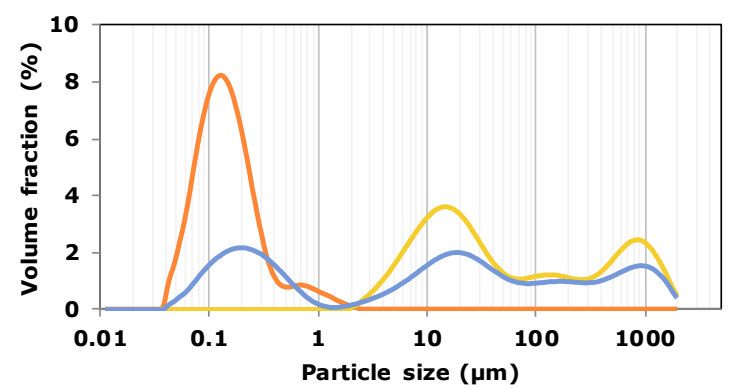

Figure 7.4. Particle size distribution of SPI and PPC original dispersion (blue line), the pellet (yellow) and the supernatant (orange) from $5 \%$ protein dispersion of (A) SPI heated at $90^{\circ} \mathrm{C}$, (B) SPI heated at $120^{\circ} \mathrm{C}$, (C) PPC heated at $90^{\circ} \mathrm{C}$ and (D) PPC heated at $120^{\circ} \mathrm{C}$ for $30 \mathrm{~min}$.

The solubility of the spray dried encapsulates and the clusters in the unheated dispersions were low (Table 7.1) and resistant to disintegration under centrifugal forces. Only $22.6 \%$ of protein ended up in the supernatant, while $77.4 \%$ was found in the pellet.

The solubility of the protein in the heated dispersions was significantly better compared to the unheated samples, with no significant difference between 90 and $120^{\circ} \mathrm{C}$ (Table 7.1). This better solubility can be at least partly attributed to the disruption of the encapsulates. 
Table 7.1. The solubility of $5 \%$ protein dispersions unheated and heated at $90{ }^{\circ} \mathrm{C}$ and $120{ }^{\circ} \mathrm{C}$ for 30 min calculated from protein quantification with BCA assay.

\begin{tabular}{llc}
\hline Protein & Treatment & $\begin{array}{c}\text { Solubility } \\
(\%)\end{array}$ \\
\hline \multirow{3}{*}{ SPI } & Unheated & $22.6 \pm 1.9^{\mathrm{a}}$ \\
& $90^{\circ} \mathrm{C}$ & $82.4 \pm 4.3^{\mathrm{b}}$ \\
& $120^{\circ} \mathrm{C}$ & $86.0 \pm 5.0^{\mathrm{b}}$ \\
\hline \multirow{3}{*}{ PPC } & Unheated & $7.3 \pm 0.5^{\mathrm{a}}$ \\
& $90^{\circ} \mathrm{C}$ & $57.0 \pm 2.7^{\mathrm{b}}$ \\
& $120^{\circ} \mathrm{C}$ & $57.6 \pm 0.7^{\mathrm{b}}$ \\
\hline
\end{tabular}

In assessing protein aggregation through particle size, one must realise that the same particle size of unheated protein isolate has a different structure a heated dispersion. The insoluble fraction (pellet) in the latter will hereafter be referred to as a heat-induced aggregate, presuming that even some denaturation and potentially aggregation will have occurred in the unheated protein as a result of the commercial isolation process, which involves heating using several process steps.

\subsubsection{Effect of gastric environment on proteins}

The unheated and heated $5 \%$ protein dispersions were mixed with $50 \mathrm{~mL}$ water and $\mathrm{NaCl} / \mathrm{pH} 2$ solution. Soluble PPC proteins that are re-dispersed in water yield a clear solution; however as soon as the soluble PPC is put in contact with the $\mathrm{NaCl} / \mathrm{pH} 2$ solution, a precipitate or clot is formed (Figure 7.5). The same was found for soy. The gastric $\mathrm{pH}$ reduces the amount of soluble protein in the dispersion as is shown in the chromatogram with a $44 \%$ smaller area under the curve (AUC) from water to $\mathrm{NaCl} / \mathrm{pH} 2$. This reduction is mainly in high molecular weight proteins, suggesting that the clot is composed mostly of bigger aggregates. Ye et.al. (2016) observed the formation of a clot during the simulated gastric digestion of milk. They found that thermal treatment of the protein had an effect on clot density and porosity. While the pea and soy proteins undoubtedly react differently, we here see very similar behaviour compared to milk proteins. 


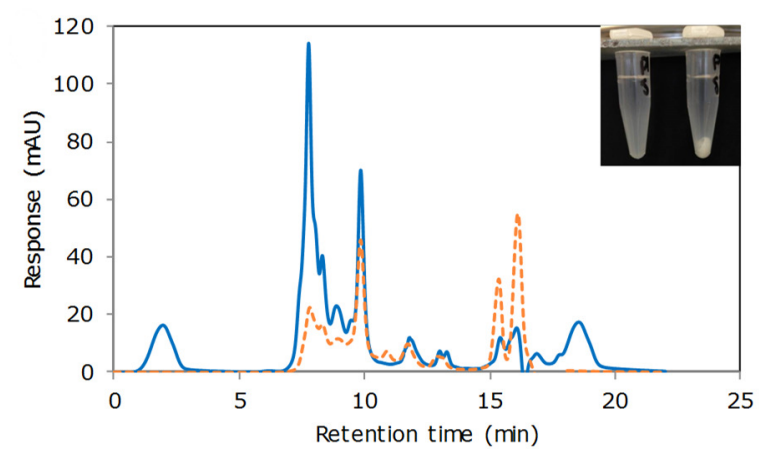

Figure 7.5. HPSEC chromatograms of undigested full dispersion of PPC in water (blue solid line) and in $\mathrm{NaCl}$ at pH 2 (orange dashed line).

We have shown that different protein species are present in the dispersions: proteins that are soluble or insoluble in water and proteins that are soluble or insoluble in gastric fluid. Gastricinsoluble particles were also observed by Overduin et.al. (2015) during in vitro digestion of pea protein isolate (PPI). They related the presence of this insoluble fraction to the observed moderate delay of intestinal bioavailability.

The particle morphology on a microscopic scale in water, a $\mathrm{NaCl}$ solution, and in the $\mathrm{NaCl} / \mathrm{Ph} 2$ solution (Figure A7.2): encapsulates could be seen in unheated dispersions which appeared stable in $\mathrm{NaCl}$ solution and even in a full gastric environment at $\mathrm{pH} 2$. The same was found for the insoluble fraction of heated dispersions.

\subsubsection{Protein hydrolysis over time}

It is known that most of the gastric protein hydrolysis occurs in the first $20 \mathrm{~min}$. Thereafter, only the peptides $<1 \mathrm{kDa}$, showed a steady increase over time (Figures 7.6A and B). While the larger soluble molecules decreased over time. This is expected with the increase of protein hydrolysis over time. Overall, little change was observed in the total concentration throughout the digestion of either SPI or PPC. The steady increases in the peptides $<1 \mathrm{kDa}$ indicate steady, ongoing overall protein hydrolysis, implying a steady increase of the DH values.

The largest increments occurred for the PPC pellet fractions. Therefore, a higher DH can be expected. This may be caused by slow solubilisation of a small part of the previously insoluble pellet components, but might also be related to the hydrophobic nature of the insoluble proteins to which pepsin is known to have a preference. After heating the dispersions, the formation of peptides (> $1 \mathrm{kDa}$ ) decreases, both for SPI and PPC, which may be because the dispersions become better soluble and less hydrophobic (Table 7.1). 
The soluble protein fractions (supernatants) of SPI and PPC show differences. While the number of peptides after heating is clearly larger with SPI, with PPC an increase was only seen after heating at $120{ }^{\circ} \mathrm{C}$. Chen et al. (2013) in SPI and Luo et al. (2015) found similar behaviour in a study on whey protein isolate (WPI) and egg white protein (EWP): with the increase of the digestion time, the peptide formation with a size $<3 \mathrm{kDa}$ and $<2 \mathrm{kDa}$, respectively, increased considerably. The total concentration values of digested supernatant fractions remained constant over time: all soluble protein is readily available for digestion and is quickly digested into small fragments.

A
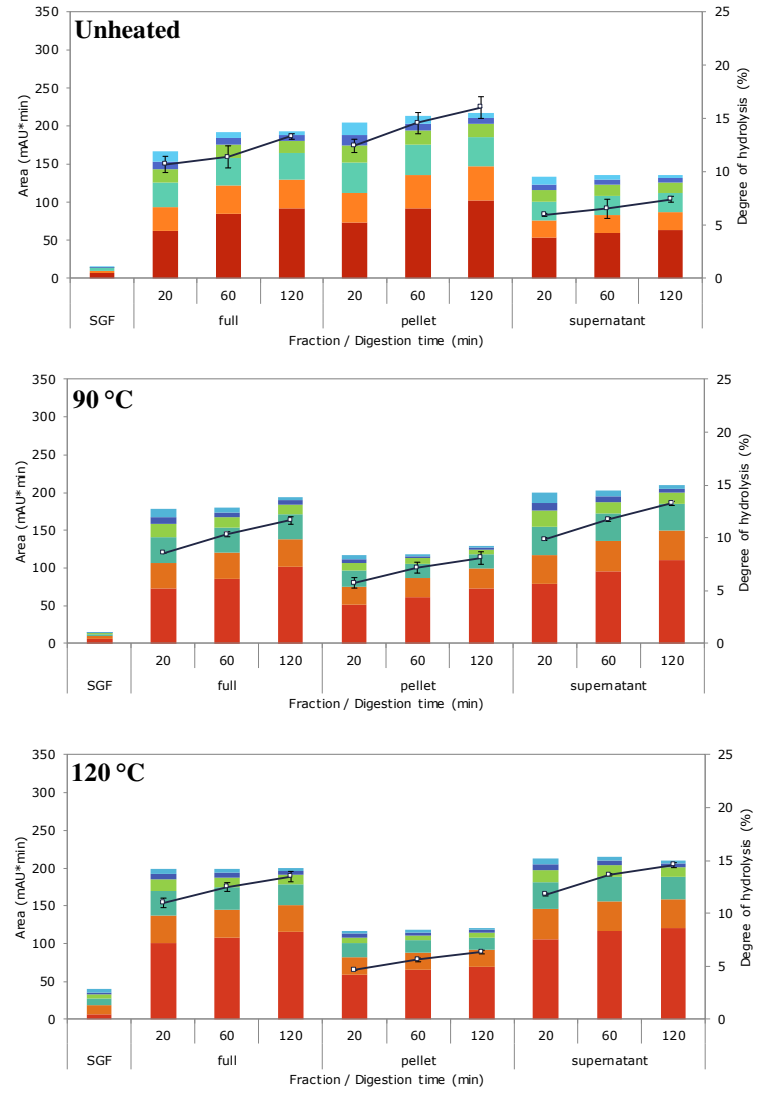

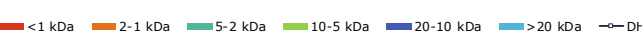

B
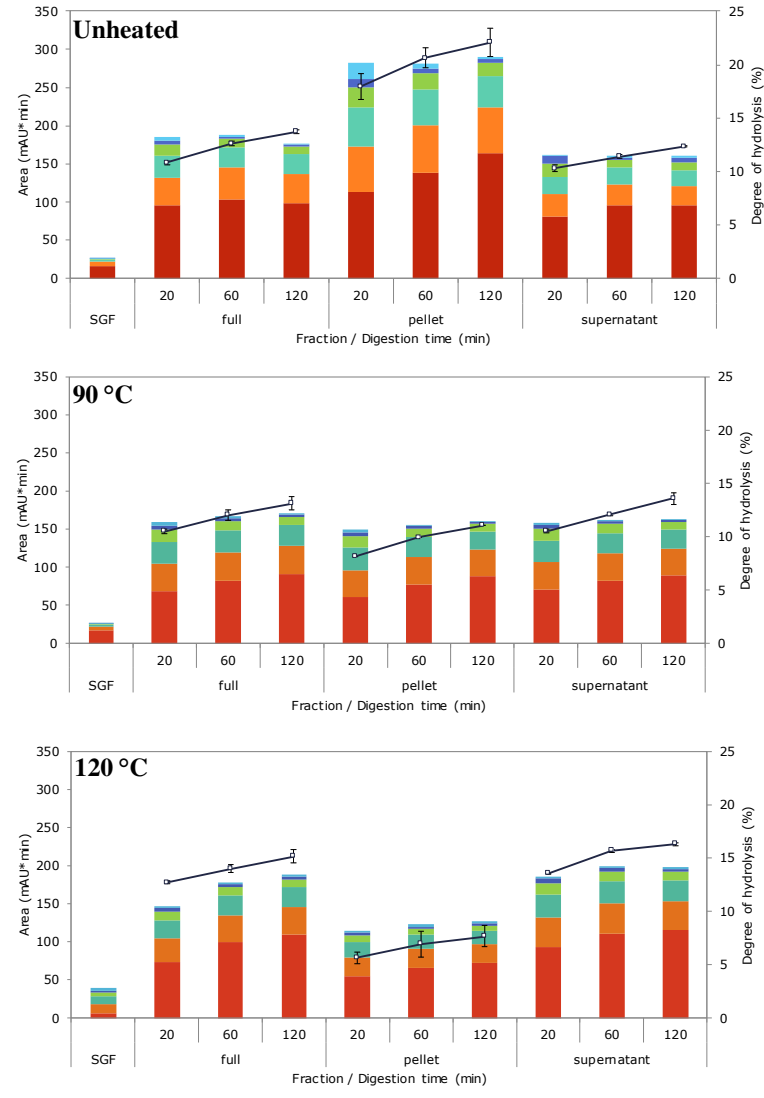

$-<1 \mathrm{kDa}=2-1 \mathrm{kDa}=5-2 \mathrm{kDa}=10-5 \mathrm{kDa}=20-10 \mathrm{kDa}=20 \mathrm{kDa} \quad-\mathrm{a}-\mathrm{DH}$

Figure 7.6. Peptide profile (bar chart) and degree of hydrolysis $(\square)$ of unheated and heated at 90 and $120^{\circ} \mathrm{C}$ for 30 min of $5 \%$ digested protein dispersions of (A) SPI and (B) PPC.

\subsubsection{Digestibility of protein full dispersions}

There was the only limited difference between the digestibility of unheated and heated full dispersions that is, dispersions that were not yet separated into a pellet and a supernatant; Figures $6 \mathrm{~A}$ and $\mathrm{B}$ after 120 min of gastric digestion. This would lead to the conclusion that heat treatment does not have a great effect on the ultimate protein digestibility of soy and pea proteins. However, a slight effect was found with PPC. While the in vitro protein digestibility 
of SPI after 120 min of pepsin digestion is not dependent on the heating treatment, PPC preheated at $120{ }^{\circ} \mathrm{C}$ showed a slightly higher protein digestibility.

The DH values with SPI are not in accordance with the HPSEC results obtained. These measurements showed a clearly more peptide formation after heating at $120{ }^{\circ} \mathrm{C}$, but this was not reflected in the DH values obtained. Therefore, this higher protein hydrolysis cannot be translated into higher $\mathrm{DH}$ values.

The PPC did show slightly higher DH values after heating at 90 and $120{ }^{\circ} \mathrm{C}$ in comparison with SPI. Therefore, PPC is somewhat better digestible than SPI. The HPSEC analysis of PPC showed an increase in the concentration of small peptides $(>1 \mathrm{kDa})$ after heating at $120{ }^{\circ} \mathrm{C}$, which is in line with the DH values obtained. Heating does not negatively affect the protein digestibility of SPI and PPC. The slight heat-induced enhancement of the digestibility of PPC might be due to partial unfolding of the globular proteins subunits. The degree of denaturation of both commercial isolates is unknown, and could also influence the digestibility.

\subsubsection{Digestibility of soluble fractions}

The digestibility of the soluble protein dispersions of SPI and PPC (that is, the supernatants) was significantly improved ( $>0.05)$ after heating and to a higher extent for SPI than for PPC protein. Heating enhanced the degree and the rate of proteolysis as compared to unheated SPI and PPC dispersions. This increase was dependent on the heating temperature: with a higher heating temperature, higher DH values were obtained. We did observe (Figure 7.4) that heating at higher temperatures gives a larger fraction of very small aggregates. The larger surface area of this fraction may render the proteins overall better accessible to pepsin, and thus may yield higher and faster overall digestibility. Proteins in the commercial PPC under study appear more heat resistant than those from SPI.

\subsubsection{Digestibility of insoluble fractions}

The insoluble fraction (the pellets) of the unheated dispersions showed significantly higher ( $p>0.05)$ protein digestibility compared to the supernatant (soluble proteins) and full dispersions (Figures 7A and B). The insoluble fraction of the unheated PPC yielded higher DH values than SPI, but both SPI and PPC showed lower digestibility with higher heating temperatures. 
The light microscopy observations in Figure 7.7 show a steady degradation of the encapsulates under gastric digestive conditions. Since we demonstrated that the encapsulates present in the pellet are stable under gastric conditions without pepsin (Figure A7.2), this degradation is due to enzymatic hydrolysis. Thus, solubility is not a prerequisite for a protein to be pepsindigestible.

Nevertheless, heating significantly reduced the digestibility compared to the unheated pellets. The slight reduction of digestibility between the 90 and $120{ }^{\circ} \mathrm{C}$ treatment could be associated with the formation of more and larger aggregates.

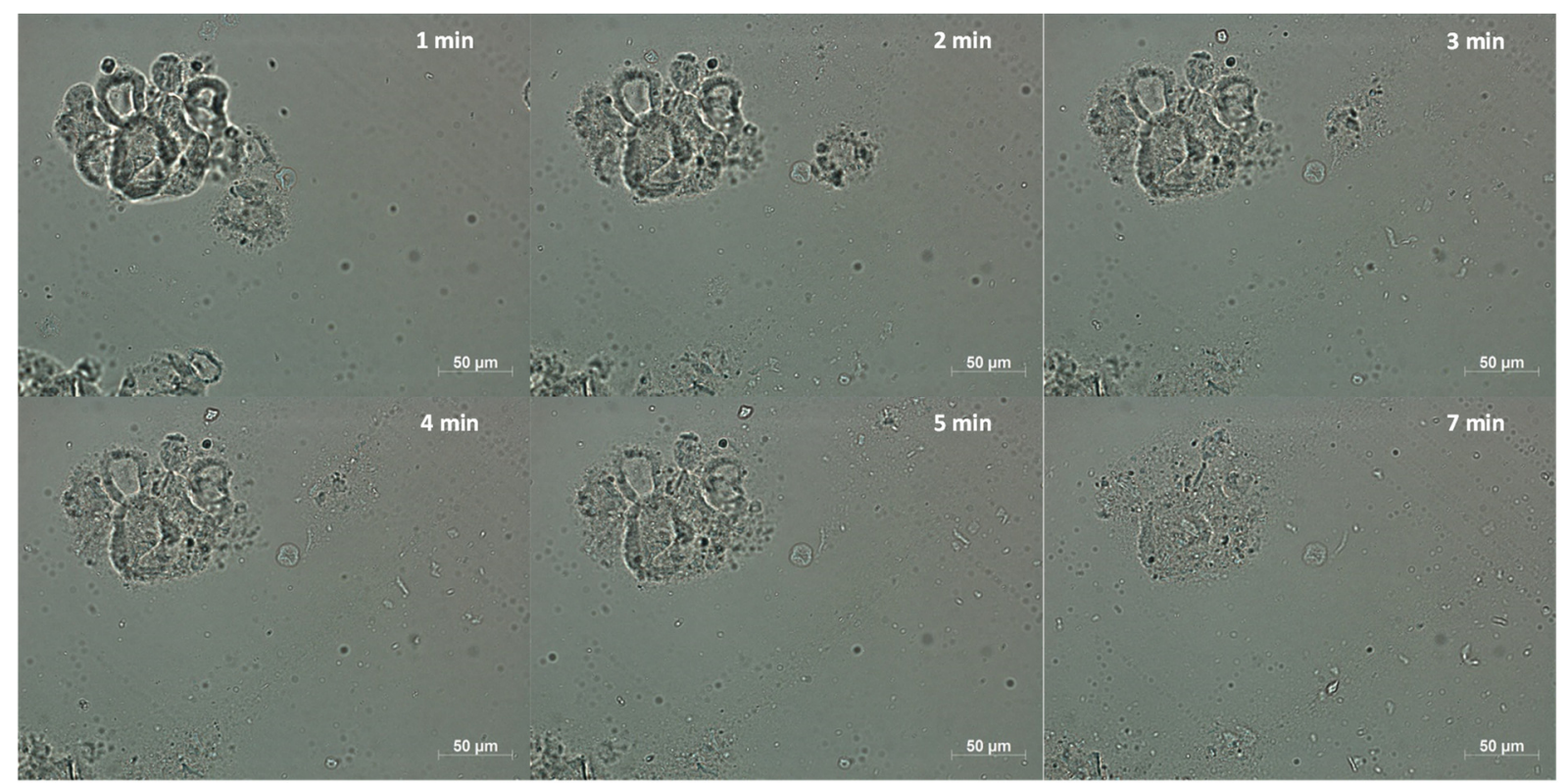

Figure 7.7. Light microscopy observations of the pellet fraction of an unheated $5 \%$ SPI dispersion, digested in $\mathrm{SGF}($ pepsin $+\mathrm{NaCl} / \mathrm{pH} 2)$.

After heating at $90{ }^{\circ} \mathrm{C}$, a few encapsulates could still be found in the insoluble fraction (Figure 7.8). The size and shape of these capsules in a gastric digestive environment remained unchanged over time, and therefore these capsules were not digested. Therefore, the heat treatment may modify the encapsulate and makes it less digestible, perhaps due to further aggregation of neighbouring proteins. The resulting reduction in porosity and swelling may hinder pepsin in diffusion and subsequent digestion. 


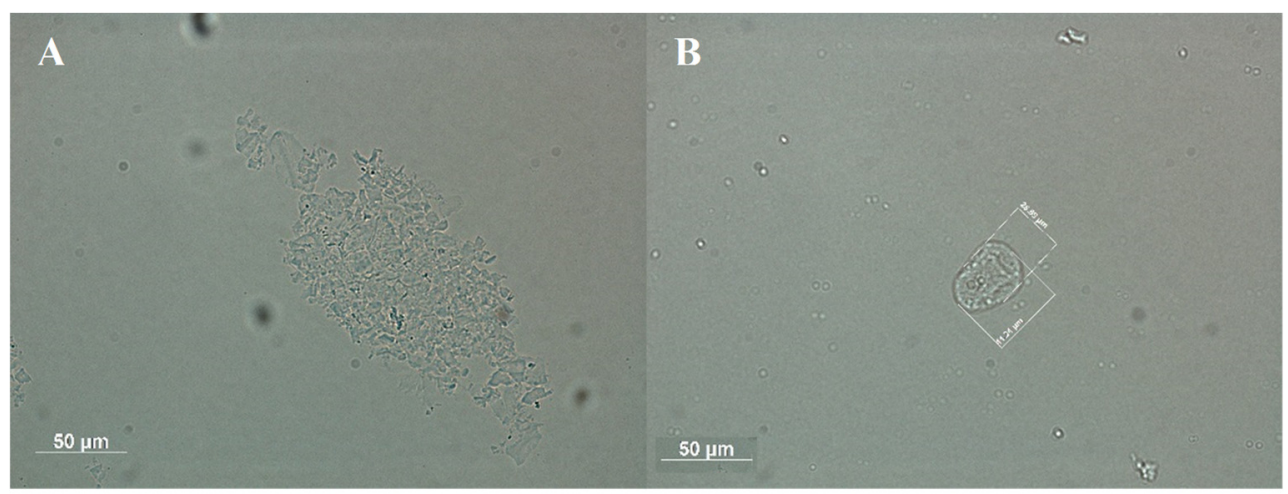

Figure 7.8. Pellet fraction of protein dispersions heated at $90{ }^{\circ} \mathrm{C}$ for $30 \mathrm{~min}$ and digested for $10 \mathrm{~min}$ in $\mathrm{SGJ}$ of (A) SPI and (B) PPC.

\subsection{CONCLUSIONS}

The digestion rate and overall digestibility are determined both by the properties of the raw materials as well as the extraction methods used to isolate the proteins.

The microstructure and solubility of pea and soy protein isolates affect their in vitro gastric digestibility. While a heat treatment of PPC and SPI dispersions increases their solubility, and the soluble proteins are well digestible and even more so when heated at higher temperatures, the remaining insoluble fractions become less digestible by the heat treatment. Protein dispersions heated at $120{ }^{\circ} \mathrm{C}$ showed more very small aggregates, which leads to faster and better (in vitro) digestion.

During digestion, small peptides smaller than $1 \mathrm{kDa}$ were formed over the digestion time in all dispersions studied. However, these are not fully related to the DH values.

The undissolved agglomerates (encapsulates) in the pellets of unheated dispersions can be readily digested by pepsin; however, the microstructure of heat-induced aggregates hindered penetration and action of pepsin, reducing the digestibility of these insoluble fractions of heated dispersions. It is therefore clear that there is no straight relation between protein solubility and digestion.

\subsection{REFERENCES}

Adler-Nissen, J. (1986). Enzymic hydrolysis of food proteins. New York: Elsevier Applied Science Publishers, pp. 110-169.

Bhagavan, N.V., CHAPTER 12 - Gastrointestinal Digestion and Absorption, in Medical Biochemistry (Fourth Edition). 2002, Academic Press: San Diego pp. 197-224. 
Casey, B.E., \& Laidler, K.J. (1951). The kinetics and mechanism of the heat inactivation of pepsin. Journal of the American Chemical Society, 73, 1455-1457.

Chen, N., Zhao, M., \& Sun, W. (2013). Effect of protein oxidation on the in vitro digestibility of soy protein isolate. Food Chemistry, 141, 3224-3229.

Egbert, W.R., \& Payne, C.T. (2009). Plant proteins, in Ingredients in Meat Products. Springer (Chapter 5).

Elkington, J. (1994). Towards the sustainable corporation: Win-win-win business strategies for sustainable development. California management review, 36(2), 90-100.

Favaro-Trindade, C.S., Santana, A.S., Monterrey-Quintero, E.S., Trindade, M.A., \& Netto, F.M. (2010). The use of spray drying technology to reduce bitter taste of casein hydrolysate. Food Hydrocolloids, 24, 336-340.

Frikha, M., Valencia, D.G., de Coca-Sinova, A., Lázaro, R., \& Mateos, G.G. (2013). Ileal digestibility of amino acids of unheated and autoclaved pea protein concentrate in broilers. Poultry Science, 92, 1848-1857.

Gerrard, J.A., Lasse, M., Cottam, J., Healy, J.P., Fayle, S.E., Rasiah, I., Brown, P.K., BinYasir, S.Md. Sutton, K.H., \& Larsen, N.G. (2012). Aspects of physical and chemical alterations to proteins during food processing-some implications for nutrition. The British journal of nutrition, 108, S288-S297.

Levesque, C.L. (2015). Amino acids in higher plants. In, J. D'Mello (Eds.), Metabolic amino acid availability in foods of plant origin: implications for human and livestock nutrition (pp. 497-506). Boston: CAB International.

Li, X., Li, Y., Hua, Y., Qiu, A., Yang, C., \& Cui, S. (2007). Effect of concentration, ionic strength and freeze-drying on the heat-induced aggregation of soy proteins. Food Chemistry, 104, 1410-1417.

Linsberger-Martin, G., Weiglhofer, K., Phuong, T.P.T., \& Berghofer, E. (2013). High hydrostatic pressure influences antinutritional factors and in vitro protein digestibility of split peas and whole white beans. LWT-Food Science and Technology, 51(1), 331336.

Luo, Q., Borst, J.W., Westphal, A.H., Boom, R.M., \& Janssen, A.E.M. (2017). Pepsin diffusivity in whey protein gels and its effect on gastric digestion. Food Hydrocolloids, $66,318-325$.

Luo, Q., Boom, R.M., \& Janssen, A.E.M. (2015). Digestion of protein and proteins gels in simulated gastric environment. LWT-Food Science and Technology, 63, 161-168.

He, T., Spelbrink, R.E.J., Witteman, B.J., \& Giuseppin, M.L.F. (2013). Digestion kinetics of potato protein isolates in vitro and in vivo. International Journal of Food Sciences and Nutrition, 64(7), 787-793. 
Hejazi, S.N., Orsat, V., Azadi, B., \& Kubow, S. (2016). Improvement of the in vitro protein digestibility of amaranth grain through optimization of the malting process. Journal of Cereal Science, 68, 59-65.

Mession, J.-L., Assifaoui, A., Cayot, P., \& Saurel, R. (2012). Effect of pea proteins extraction and vicilin/legumin fractionation on the phase behavior in admixture with alginate. Food Hydrocolloids, 29, 335-346.

Nielsen, S.S. (1991). Digestibility of legume proteins. Food Technology, 45, 112-118.

Nyemb, K., Guérin-Dubiard, C., Dupont, D., Jardin, J., Rutherfurd, S.M., \& Nau, F. (2014). The extent of ovalbumin in vitro digestion and the nature of generated peptides are modulated by the morphology of protein aggregates. Food Chemistry, 157, 429-438.

Opazo-Navarrete, M., Schutyser, M.A.I., Boom, R.M., \& Janssen, A.E.M. (2017). Effect of pre-treatment on in vitro gastric digestion of quinoa protein (Chenopodium quinoa Willd.) obtained by wet a nd dry fractionation. International Journal of Food Science and Nutrition, 69(1), 1-11.

Overduin, J., Guérin-Deremaux, L., Wils, D., \& Lambers, T.T. (2015). NUTRALYS ${ }^{\circledR}$ pea protein: characterization of in vitro gastric digestion and in vivo gastrointestinal peptide responses relevant to satiety. Food \& Nutrition Research, 59, 25622http://dx.doi.org/10.3402/fnr.v59.25622

Pelgrom, P.J.M., Berghout, J.A.M., van der Goot, A.J., Boom, R.M., \& Schutyser, M.A.I. (2014). Preparation of functional lupine protein fractions by dry separation. LWT-Food Science and Technology, 59, 680-688.

Petruccelli, S., \& Añón, M. C. (1996). pH-induced modifications in the thermal stability of soybean protein isolates. Journal of Agricultural and Food Chemistry, 44(10), 30053009.

Rocha, G.A., Trindade, M.A., Netto, F.M., \& Favaro-Trindade, C.S. (2009). Microcapsules of casein hydrolysate: production, characterization, and application in protein bar. Food Science and Technology International, 15(4), 407-413.

Ruiz, G.A., Opazo-Navarrete, M., Meurs, M., Minor, M., Sala, G., van Boekel, M., Stieger, M., \& Janssen, A.E.M. (2016). Denaturation and in Vitro Gastric Digestion of Heat-Treated Quinoa Protein Isolates Obtained at Various Extraction pH. Food Biophysics, 11(2), 184-197.

Salazar-Villanea, S., Bruininx, E.M.A.M., Gruppen, H., Carré, P., Quinsac, A., \& van der Poel, A.F.B. (2017). Effects of Toasting Time on Digestive Hydrolysis of Soluble and Insoluble oo-Rapeseed Meal Proteins. Journal of the American Oil Chemists' Society, 94, 619-630.

Shand, P.J., Ya, H., Pietrasik, A., \& Wanasundara, P.KP.D. (2007). Physicochemical and textural properties of heat-induced pea protein isolate gels. Food Chemistry, 
102(4),1119-1130.

Syll, O., Khalloufi, S., \& Schuck, P. (2013). Dispersibility and morphology of spray-dried soy powders depending on the spraying system. Dairy Science \& Technology, 93(4-5), 431442.

Tang, C.-H., Chen, L., \& Ma, C.-Y. (2009). Thermal aggregation, amino acid composition and in vitro digestibility of vicilin-rich protein isolates from three Phaseolus legumes: A comparative study. Food Chemistry, 113, 957-963.

Tang, C.-H., Choi, S.-M., \& Ma, C.-Y. (2007). Study of thermal properties and heat-induced denaturation and aggregation of soy proteins by modulated differential scanning calorimetry. International Journal of Biological Macromolecules, 40(2), 96-104.

Veronica, S. C., \& Mitsuo, J. (2011). Inhibition of soybean lipoxygenases e structural and activity models for the lipoxygenase isoenzymes family. In D. Krezhova (Ed.), Recent trends for enhancing the diversity and quality of soybean products. Shanghai: InTech. pp. 109-130.

Wang, H., Faris, R.J., Wang, T., Spurlock, M.E., \& Gabler, N. (2009). Increased in vitro and in vivo digestibility of soy proteins by chemical modification of disulphide bonds. Journal of the American Oil Chemists' Society, 86, 1093-1099.

Ye, A., Cui, J., Dalgleish, D., \& Singh, H. (2016). Formation of a structured clot during the gastric digestion of milk: Impact on the rate of protein hydrolysis. Food Hydrocolloids, $52,478-486$. 


\subsection{Appendix}

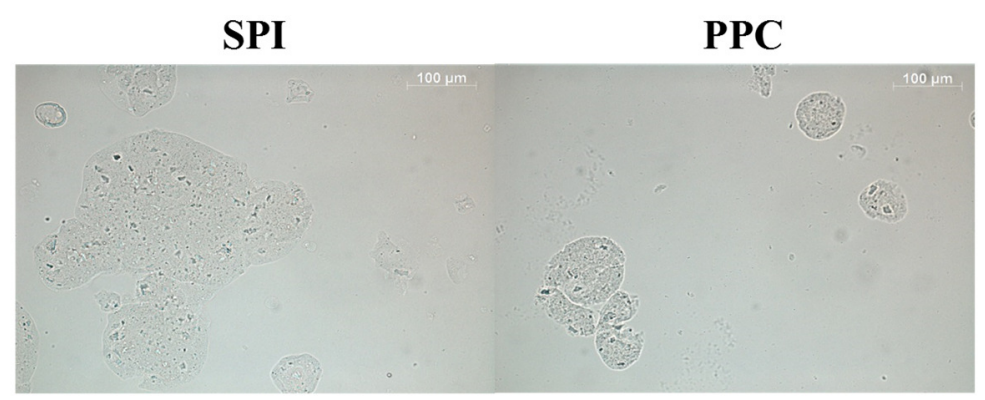

Figure A7.1. Light microscopy observations of unheated 5\% SPI and PPC samples dispersed in water.

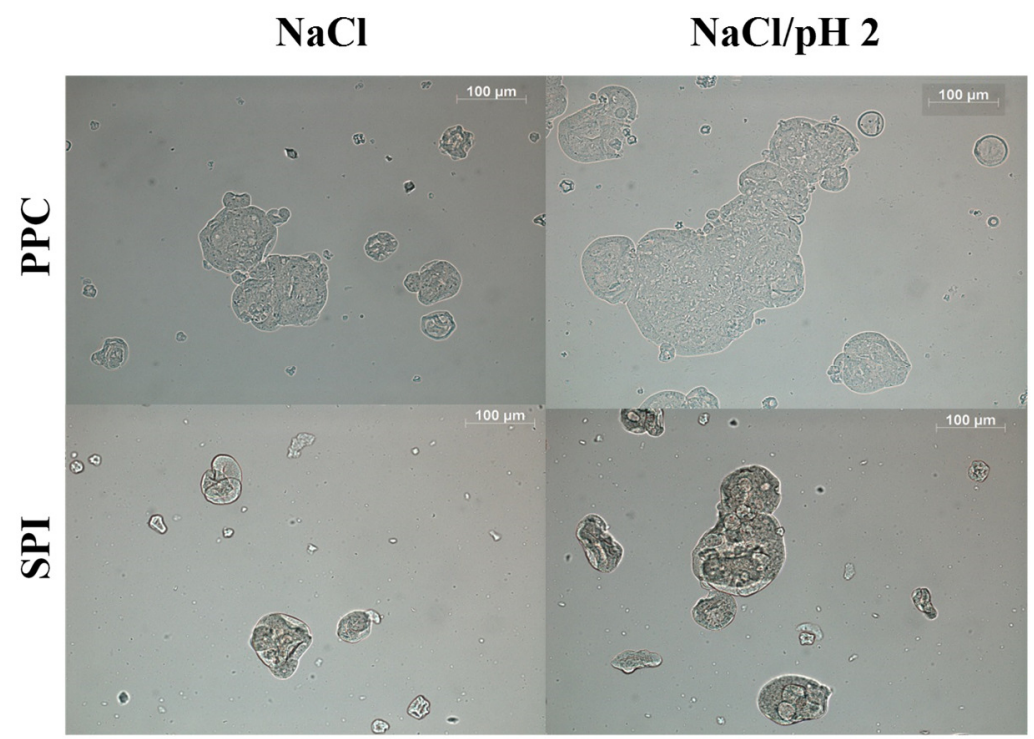

Figure A7.2. Light microscopy observations of unheated 5\% SPI and PPC samples dispersed in $\mathrm{NaCl}$ and $\mathrm{NaCl}$ solution at $\mathrm{pH} 2$. 
Chapter 7 


\section{Chapter 8}

General Discussion 


\subsection{Introduction}

This thesis aimed towards a better understanding of the effect of processing on the (in vitro) gastric digestibility of plant proteins. We showed that the image of plant proteins, necessarily having an inferior amino acid profile and relatively poor digestibility in comparison with animal proteins, is not correct. Although not all plant-based foods contain all of the essential amino acids, quinoa protein has an excellent amino acid profile. This thesis showed that the protein digestibility is a major determinant of the bioavailability of these amino acids. The protein digestibility is strongly influenced by the processing and isolation methods rather than only by the protein source. Therefore, the focus of this thesis was to study the effect of different conditions during processing (heating, $\mathrm{pH}$ during protein isolation, etc.) on the digestibility of plant proteins. While different proteins were studied, the focus was on quinoa proteins obtained via a dry and wet fractionation method. This chapter summarizes the main findings of the preceding chapters and ends with an outlook towards future research.

\subsection{Discussion of main findings}

The conventional methods for isolating or concentrating plant proteins involve hydration and dissolution, sometimes precipitation, and always dehydration. These routes are not only intensive in the use of resources, they also change the properties of the proteins. Therefore, the new process of dry fractionation, which avoids hydration and dissolution, was compared to more conventional methods of isolation. We did this with the crop that was our focus: quinoa. Chapter 2 discussed the effects of pre-heating on the in vitro gastric digestibility of quinoa protein isolate (QPI) that was obtained via the traditional wet fractionation process, and on quinoa protein concentrate (QPC) that was obtained via the new dry fractionation process. The dry fractionation process gives functional, but relatively impure protein fractions. Therefore, special attention was paid to the remaining starch present in the QPC. Both unheated and heated QPC showed better gastric protein digestibility than QPI. The very good digestibility of unheated QPC suggests that the protein is more available for pepsin after dry fractionation.

In Chapter 3, it was shown that the properties of quinoa protein vary according to the $\mathrm{pH}$ and processing conditions applied during the protein extraction process. While the protein yield can be increased from 24 to $37 \%$ when increasing the extraction $\mathrm{pH}$ from 8 to 11 , the protein purity does not seem to be affected. The quinoa protein digestibility decreases with increasing extraction $\mathrm{pH}$, which is a consequence of protein aggregation at high extraction $\mathrm{pH}$. Together 
with the extraction $\mathrm{pH}$, the processing temperature influences the protein digestibility. Heating quinoa protein at 90 and $120^{\circ} \mathrm{C}$ yields a decrease in the digestibility.

To obtain better insight in the differences between proteins from different sources, we studied the digestion of soy protein isolate (SPI), pea protein concentrate (PPC), albumin from chicken egg white and whey protein isolate (WPI), forming gels after heating at different temperatures with different microstructures. This was reported in Chapter 4. The differences in digestibility were related to the differences in the microstructure of the gels. SPI gels showed no discernible structural differences when gelled at different temperatures, while PPC gelled at $140{ }^{\circ} \mathrm{C}$ clearly had a more fragile structure, which resulted in a fast gastric gel breakdown and faster protein digestion. Proteins from animal origin sources yield different structures. WPI gelled at different temperatures did not show any change in morphology, but albumin from chicken egg white gelled at $90{ }^{\circ} \mathrm{C}$ showed a more compact structure in comparison to the gels made at 120 and $140{ }^{\circ} \mathrm{C}$. This more compact structure resulted in slower gel disintegration during gastric digestion and therefore slower protein digestion.

Since dry fractionation methods do not give very pure fractions, we studied improvements based on a method to concentrate quinoa proteins from sweet quinoa varieties (Atlas and Riobamba) and the possibility to isolate starch in Chapter 5. Quinoa proteins were concentrated from quinoa seeds up to a concentration of around 32\% (g protein/100 g dry solids), but starch was successfully isolated to much higher purities ( 86 - $89 \mathrm{~g}$ starch/100 g dry solids). The dry fractionated method suggested is more resource efficient than the conventional isolation methods. The quinoa protein produced with this process, shows high water retention capacity and solubility when unheated, while the gelatinization temperature of the starch fraction is influenced by the residual presence of proteins.

The focus of dry fractionation is on the functionality of the fractions, and not on their purities. The fractions obtained therefore have large amounts of other components such as starch, fibre an oil. In Chapter 6 we studied the influence of starch and fibres on the in vitro gastric digestibility of unheated and heated quinoa protein suspensions from the Riobamba variety. The protein digestibility is indeed influenced by the presence of these components, which resulted in a reduction of the degree of hydrolysis that could be obtained. The presence of starch results in a larger reduction of the protein digestibility than the presence of fibre. We attribute the lower digestibility in the presence of fibre and starch to the poorer accessibility of the matrix to pepsin. 
Thermal processing is the most common treatment used for food; not only for preservation purposes, but also to create the right consistency of the food product. Heating generally produces aggregation of proteins, which affects the protein digestibility. Chapter 7 aimed at a better understanding of the relation between this aggregate formation and in vitro digestion of soy protein isolate and pea protein concentrate. Heating does not affect the protein digestibility of protein solutions or dispersions as such. However, heating does result in a fraction of the proteins becoming insoluble, leaving the rest of the protein in solution. Heating improves the protein digestibility of the soluble proteins of soy and pea protein that remain in solution after heating, while the insoluble fraction shows reduced protein digestibility.

Overall, we may draw three important overall conclusions.

1. Quinoa protein can be well isolated using conventional wet processes, yielding a relatively pure QPI, but can also be concentrated using the new dry fractionation process. The quinoa protein is well digestible according to the in vitro gastric assay that was used here.

2. The conditions during processing of the raw materials into protein isolate or concentrate has a strong effect on the gastric digestion: the thermal load during this process, but also the $\mathrm{pH}$ applied during the isolation process change the gastric digestion perhaps even stronger than the differences between the different protein sources.

3. The digestion of dissolved protein is relatively fast, while that of gelled protein is significantly slower; however, the presence of other components such as starch or fibre slows the gastric digestion significantly down. This is probably due to the lower amount of gastric fluid that is available for the protein, the lower swelling of the protein, and the subsequent slower diffusion of pepsin into the protein matrix.

\subsection{Improving the separation process of plant proteins}

Current techniques for fractionation of raw materials into protein and other fractions have been designed with the purity of the fractions in mind; however, they are quite intensive in water and energy usage and lose a significant part of the raw material as waste or as solids in wastewater. Given the societal challenges as outlined in Chapter 1, future fractionation processes should be much more efficient in the use of water and energy and should render much more of the raw materials into ingredients that have high nutritive value for humans.

Dry fractionation, which complies with these guidelines, makes use of the differences in mechanical properties between different parts of the plant cell. The sweet varieties of quinoa 
(Chenopodium quinoa Willd.), which are virtually free of saponins $(<0.11 \%)$ can be dry fractionated to provide high-quality protein and starch, as is reported in this thesis. The quinoa proteins are located in the embryo and starch in the perisperm (Figure 8.1A). A similar morphology as in quinoa is present in amaranth (Figure 8.1B) and kañiwa, among other plants. Processing of these seeds must be majorly influenced by the morphology of the seed, particularly as the embryo surrounds the starch-rich perisperm.

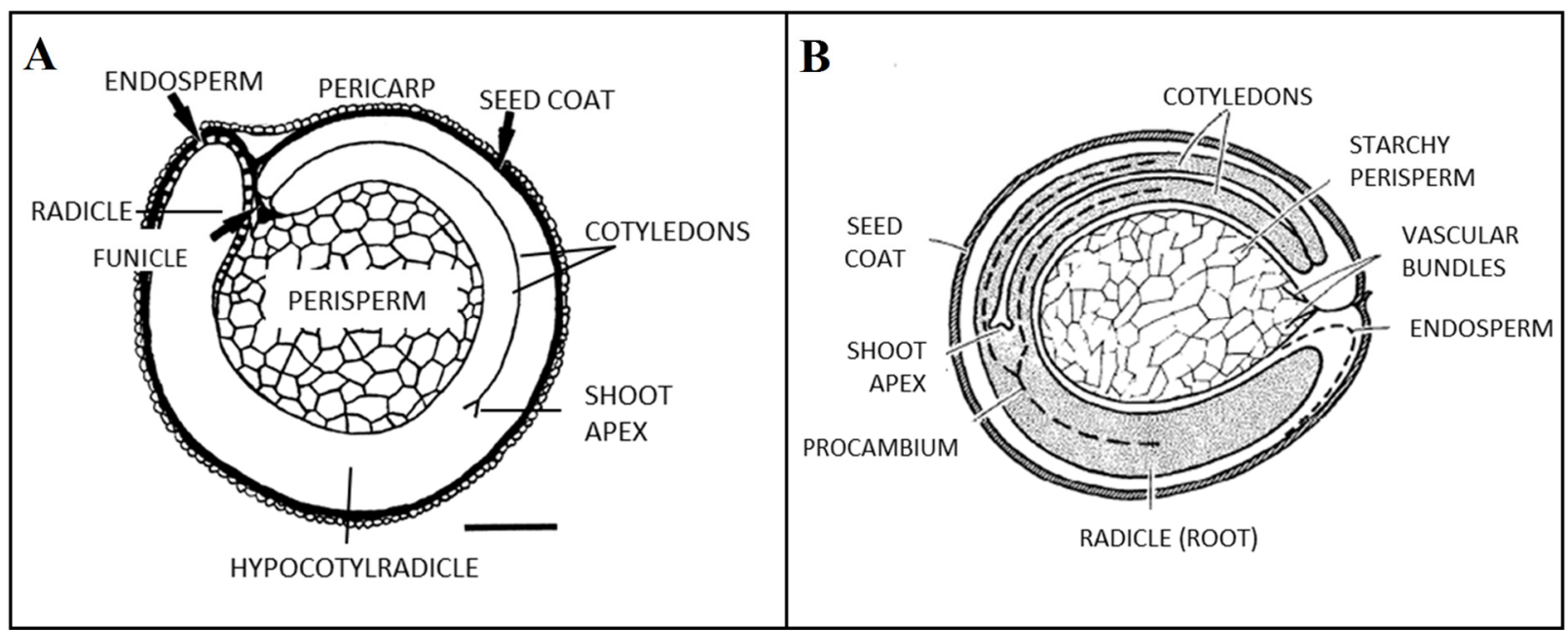

Figure 8.1. Illustration of a longitudinal section of (A) quinoa and (B) amaranth seeds. Adapted from ValcárcelYamani \& da Silva (2012).

In our laboratory, amaranth proteins were successfully separated from the seed using the same method as proposed in Chapter 2 (Table 8.1). However, the protein-enriched fraction was, in this case, the fraction with a particle size smaller than $0.315 \mathrm{~mm}$, while in quinoa the proteinenriched fraction was the one between the sieves of $0.63-0.315 \mathrm{~mm}$. This is because the amaranth seed is smaller than quinoa seed. The separation process could be enhanced using different sieve sizes and different dry fractionation techniques, such as air classification and electrostatic separation.

Table 8.1. Experimental characterization of amaranth fractions after sieving.

\begin{tabular}{lc}
\hline \multicolumn{1}{c}{ Fractions } & $\begin{array}{c}\text { Protein content } \\
(\mathrm{w} / \mathrm{dw})\end{array}$ \\
\hline Whole Seed & $11.5 \pm 1.1$ \\
$>0.63 \mathrm{~mm}$ & $8.9 \pm 1.1$ \\
$0.63-0.5 \mathrm{~mm}$ & $4.9 \pm 0.1$ \\
$<0.315 \mathrm{~mm}$ & $32.0 \pm 2.5$ \\
\hline
\end{tabular}

Schutyser et al. (2015) indicated that our knowledge on legume morphology should be extended, especially related to the adhesion and hardness of fibre, protein bodies and starch 
granules. This information can be used to estimate the fracture behaviour during milling, improve the detachment of the different tissues, and to optimally design the equipment.

The most important step in dry fractionation techniques is milling: insufficient milling will not result in detachment of the different tissues and poor separation; over-milling will result in damaged starch, and clumping of the small particles due to moisture bridging or Van der Waals forces, also resulting in poor separation later in the process.

\subsection{Implications of the separation process on the protein functionality}

The protein digestibility is affected by the processing applied prior to consumption and digestion. Highly purified protein isolates are often used as food ingredients. However, the isolation process does affect the protein functionality. The conventional wet fractionation process is based on the water solubility of components at different solvent qualities. By making use of organic solvents and $\mathrm{pH}$ switches, water-soluble and water-insoluble components are separated. For instance, in Chapter 5, we have proposed a sustainable process to concentrate quinoa proteins and, at the same time, isolate starch (Figure 8.2).

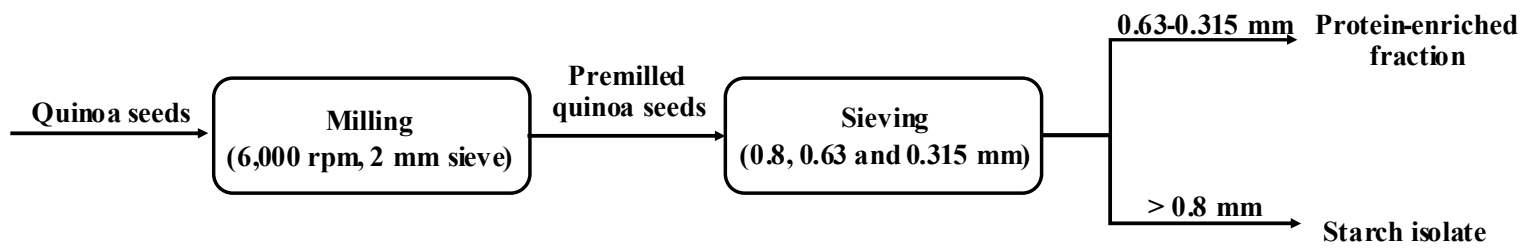

Figure 8.2. Dry fractionation process proposed to quinoa seeds in Chapter $\mathbf{5}$.

It is not clear at this moment what the functional properties of the dry fractionated ingredients are, such as foaming, gelling, solubility, emulsification, viscosity, etc. Pelgrom et al. (2013) found that pea protein concentrate using dry milling in combination with air classification showed higher water holding capacity (WHC) than PPI resulting from the conventional wet extraction. This was explained by the high solubility of pea protein in its native state. When exploring the foaming properties of lupine protein concentrates obtained by dry fractionation it was found that the foaming properties of the concentrate improved drastically after defatting (Pelgrom et al., 2014). Day (2013) indicated that native pulse proteins are relatively rich in albumins. Less pure protein concentrates are associated with health benefits compared to completely refined proteins, but the presence of specific components may also have an adverse health effect if not processed adequately (Jacobs et al., 2009). 


\subsection{Implications of protein oxidation on the protein digestibility}

Heating is the widest applied treatment used for food. However, the thermal load affects both the protein functionality and the digestibility of plant proteins. Aside from denaturation and changes in the protein itself also the interaction of the proteins with other components, such as starch and fibre, changes, reducing the digestibility of the proteins. This was discussed in

\section{Chapter 6.}

Recently, a change in food proteins due to thermal processing has come under scrutiny: oxidation (Chen et al., 2013). Proteins can be oxidised directly by reactive oxygen species or indirectly by reaction with the by-products of lipid peroxidation, resulting in a number of changes in amino acid residue side-chains and in the protein polypeptide backbone (Shacter, 2000). Proteins are major targets for oxidants because of their high abundance in biological systems and high rate constants for reaction with oxidants (Davies, 2005). These modifications can lead to protein fragmentation, cross-linking, unfolding and conformational changes (Davies, 2005). The structural changes produced by oxidation lead to decrease or loss of biological function, nutritional value, functional properties and digestibility of the target proteins (Zhang et al., 2013; Hawkins \& Davies, 2001, Dean et al., 1997).

Not much is known about the relation between heat-induced protein oxidation and the digestibility of the protein. To study this, we pre-heated at 100 and $120{ }^{\circ} \mathrm{C}$ for $30 \mathrm{~min}$ SPI and PPC dispersions and the protein oxidation was measured via the DNPH method as described by Soglia et al. (2016). The protein dispersions showed different oxidation levels (Figure 8.3). Soy protein isolate (SPI) does not show differences among unheated and heated samples for 30 min. However, the oxidation of pea protein concentrate $(\mathrm{PPC})$ increased significantly $(\mathrm{p}<0.05)$ with the increase of the temperature.

One has to realise that these ingredients are commercial ingredients. While the exact production process is unknown, it is likely that spray drying is used. Therefore, we can assume that the soy protein was already oxidised. Zhang et al. (2017) studied the effect of heating at $100^{\circ} \mathrm{C}$ in SPI solutions. They found values of protein oxidation of $7(\mathrm{mmol} / \mathrm{Kg})$ in unheated samples and 10 $(\mathrm{mmol} / \mathrm{Kg})$ in the samples heated at $100{ }^{\circ} \mathrm{C}$ for $8 \mathrm{~h}$, which is similar what we found with unheated SPI ( $11 \mathrm{mmol} / \mathrm{kg}$ ). This supports our assumption that the SPI protein was already oxidised during its production process and therefore could not be oxidised much further. Therefore, the knowledge of the nature and the processing history of the raw material is 
important. With respect to PPC, the protein oxidised increased with the increase of heating temperature, indicated that the concentration process, being milder than an isolation process, had not fully oxidised the proteins.

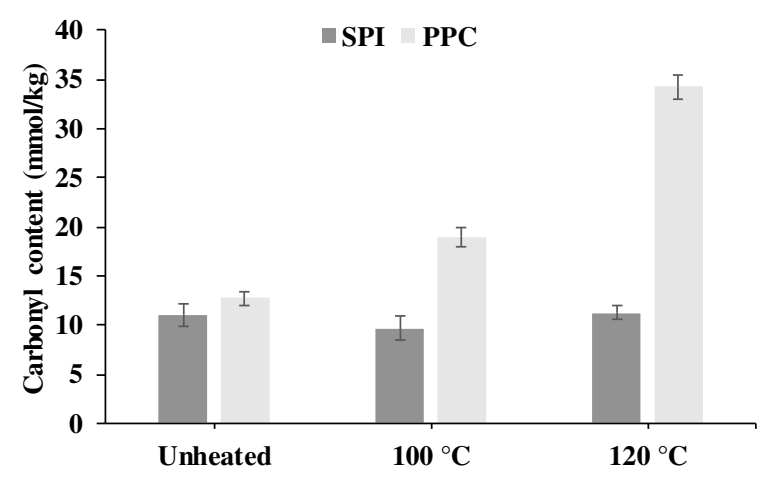

Figure 8.3. Carbonyl content (mmol/Kg soluble protein) of SPI and PPC 5\% suspensions heated at 100 and 120 ${ }^{\circ} \mathrm{C}$.

The unheated and heated SPI and PPC dispersions were digested by pepsin at $\mathrm{pH} 2$ and $37^{\circ} \mathrm{C}$ for $120 \mathrm{~min}$. The samples did not show differences in the DH values among the different treatments (Figure 8.4). Similar results were found by Chen et al. (2013) in a study in SPI solutions which were chemically oxidised. While the protein oxidation increased with the increase of AAPH (2,2'-Azobis(2-methylpropionamidine) dihydrochloride), after $60 \mathrm{~min}$ of digestion by pepsin, no significant differences $(\mathrm{p}>0.05)$ of $\mathrm{DH}$ values among samples was observed. These results are similar to the results obtained for PPC where an increase of protein oxidation did not produce an increase in the protein digestibility. Therefore, from our results, we can conclude that at least for the case of PPC heat-induced oxidation does not affect the gastric protein digestibility. However, the formation of oxidative aggregates would change the physical recognition by proteases, which might decrease the proteolytic susceptibility (Grune et al., 2004). In addition, the intestinal absorption of the final peptides and amino acids in the intestines will change, since some of the amino acids have been converted into different components. Therefore, more studies need to be done using native protein to evaluate the real effect of heat-induced protein oxidation on the protein digestibility. 

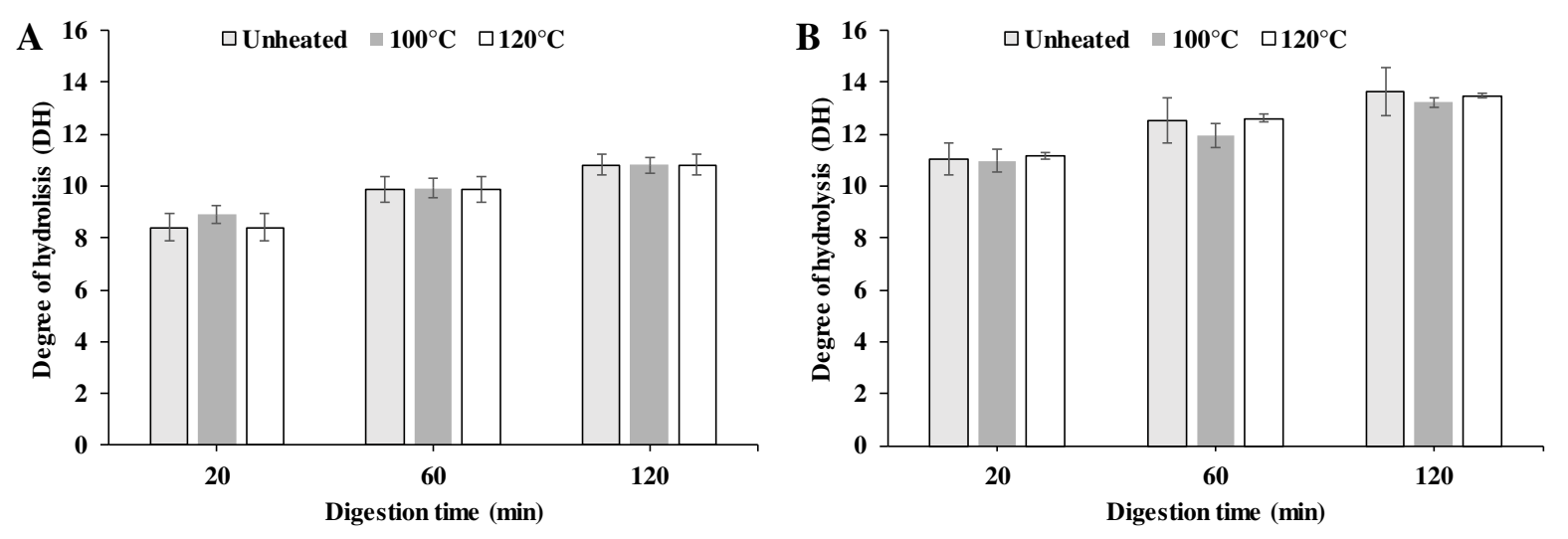

Figure 8.4. The degree of hydrolysis (DH) of unheated and heated at 100 and $120^{\circ} \mathrm{C}$ for $30 \mathrm{~min}$ of (A) SPI and (B) PPC digested according to the method described in Chapter 2.

Chen et al. (2013) did not find differences in the protein gastric digestion after protein oxidation. However, in the intestinal phase, they found that an increase in the protein oxidation produced a decrease in the degree of hydrolysis of SPI.

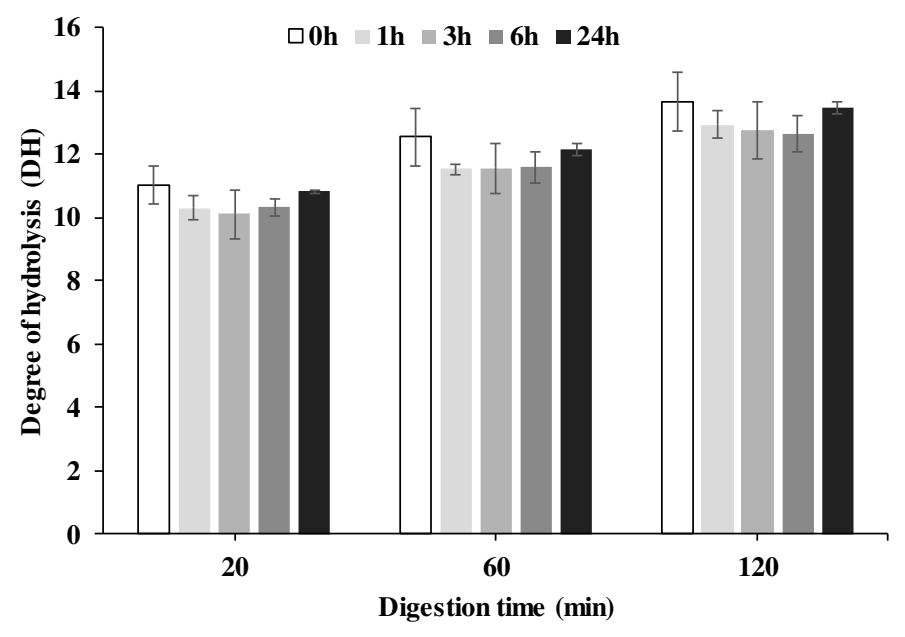

Figure 8.6. The degree of hydrolysis (DH) of PPC after metal-catalysed protein oxidation.

\subsection{Implications of pre-treatments on the protein digestibility}

The $\mathrm{pH}$ of a food is one of the several important parameters of that determine the survival and growth of microorganisms during food processing. The $\mathrm{pH}$ may also affect the protein digestibility and cause changes in the nutritional value of the protein. To study this, the 5\% SPI and PPC dispersions were pre-treated at various $\mathrm{pH}$ values and salt concentrations $(0$ and 200 $\mathrm{mM})$. Figure 8.7 shows the results of the SPI and PPC dispersions digested by pepsin. The SPI dispersions with $\mathrm{NaCl}$ added and prepared at $\mathrm{pH} 7$ and 12 showed an increase in the protein digestibility, while the samples prepared at $\mathrm{pH} 2$ did not show differences in the protein digestibility (8.7A). 
For the PPC dispersions, the protein digestibility increased when salt was added, irrespective of the $\mathrm{pH}$ at which they were pre-treated (Figure 8.7B). With salt added, SPI and PPC showed different behaviour with the different pre-treatment $\mathrm{pHs}$. The protein digestibility of SPI increased with an increase of $\mathrm{pH}$, while the digestion of PPC decreased. This effect of the ionic strength is contrary to previous studies. Butré et al. (2012) concluded that the addition of $\mathrm{NaCl}$ decreased the rate of hydrolysis of WPI digested by alcalase at low protein concentrations. However, at high concentrations $(\geq 5 \%)$ no effect was found. It was proposed that this decreased hydrolysis rate with increasing ionic strength could be due to the increased structural stability of the proteins (Yon, 1958), but the effect of the ionic strength on the hydrolysis kinetics of plant proteins is not yet understood.

The effect itself is, however, another indication that the digestibility of proteins is not just a function of the type of protein, but even more of the processing history of the protein, and of the other components present in the food product.
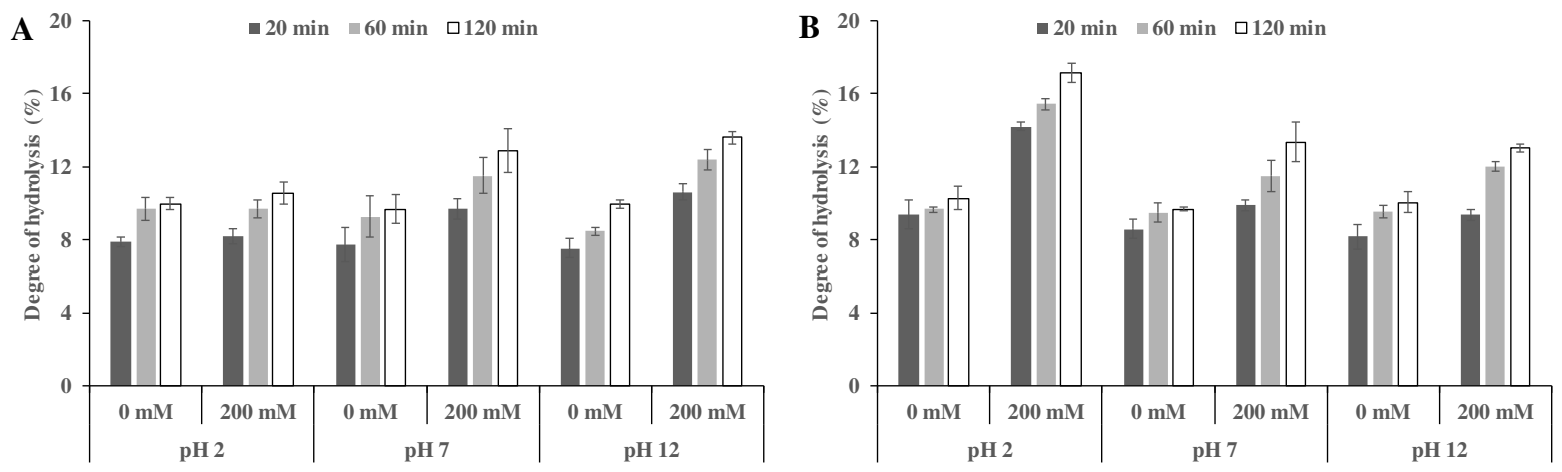

Figure 8.7. The degree of hydrolysis of protein dispersions digested by pepsin at $\mathrm{pH} 2$ and $37^{\circ} \mathrm{C}$ of (A) SPI and (B) PPC.

\subsection{Concluding remarks}

This thesis aimed at obtaining a better understanding of the (in vitro) gastric digestibility of plant food proteins.

We paid special attention to quinoa protein, being a high-quality plant protein that may deliver excellent nutrition while having relatively few downsides. Quinoa protein can be concentrated using a dry fractionation method, while starch can be isolated towards higher purity using the same method. The in vitro gastric protein digestibility of quinoa is affected by the $\mathrm{pH}$ that was used during the isolation (or concentration) from raw materials into the ingredient, and finally into the complete food product. The dry fractionation method proposed, yield native protein 
with high digestibility. Therefore, this process gives low purity, but good functionality and high digestibility while using significantly less water and energy, and utilising more of the raw material. Heating of protein solutions above the denaturation temperature negatively impacts the gastric protein digestibility of quinoa, while soy and pea proteins become better digestible. The processing temperature, but also the presence of starch and fibre in the food reduce the in vitro protein digestibility of quinoa. Therefore, it is important to consider during the food formulation.

This thesis has therefore contributed to a better understanding of the digestibility of plant proteins, which was found to be a function of the type of proteins, of the processing history, and of the formulation of the whole food.

Future research should clarify the importance of the significant changes in oxidation levels, that are observed after the isolation or concentration of proteins. While the effects on gastric digestion are small, there may be a significant impact on the final molecular resorption. In addition, the exact effects of the product formulation need to be investigated further; not just because the effects of the presence of starch, fibre and $\mathrm{pH}$ were found to be strong but also because this will bring us even further in our understanding of the exact mechanisms of gastric digestion.

\subsection{References}

Butré, C.I., Wierenga, P.A., \& Gruppen, H. (2012). Effects of ionic strength on the enzymatic hydrolysis of diluted and concentrated whey protein isolate. Journal of Agricultural and Food Chemistry, 60, 5644-5651.

Chen, N., Zhao, M., \& Sun, W. (2013). Effect of oxidation on the in vitro digestibility of soy protein isolate. Food Chemistry, 141, 3224-3229.

Davies, M.J. (2005). The oxidative environment and protein damage. Biochimica et Biophysica Acta, 1703, 93-109.

Day, L. (2013). Proteins from land plants - Potential resources for human nutrition and food security. Trends in Food Science \& Technology, 32, 25-42.

Dean, R.T., Fu, S., Stocker, R., \& Davies, M.J. (1997). Biochemistry and pathology of radicalmediated protein oxidation. Biochemical Journal, 324, 1-18. 
Grune, T., Jung, T., Merker, K., \& Davies, K.J.A. (2004). Decreased proteolysis caused by protein aggregates, inclusion bodies, plauqes, lipofuscin, ceroid, and 'aggresomes' during oxidative stress, aging, and disease. The International Journal of Biochemistry and Cell Biology, 36, 2519-2530.

Hawkins, C.L., \& Davies, M.J. (2001). Generation and propagation of radical reactions on proteins. Biochimica et Biophysica Acta - Bioenergetics, 1504, 196-219.

Jacobs, D.R., Gross, M.D., \& Tapsell, L.C. (2009). Food synergy: an operational concept for understanding nutrition. The American Journal of Clinical Nutrition, 89, 1543-1548.

Pelgrom, P.J.M., Berghout, J.A.M., van der Goot, A., Boom, R.M., \& Schutyser, M.A.I. (2014). Preparation of functional lupine protein fractions by dry separation. LWT - Food Science and Technology, 59, 680-688.

Pelgrom, P.J.M., Vissers, A.M., Boom, R.M., \& Schutyser, M.A.I. (2013). Dry fractionation for production of functional pea protein concentrates. Food Research International, 53(1), 232-239.

Schutyser, M.A.I., Pelgrom, P.J.M., van der Goot, A.J., \& Boom, R.M. (2015). Dry fractionation for sustainable production of functional legume protein concentrates. Trends in Food Science \& Technology, 45, 327-335.

Soglia, F., Petracci, M., \& Ertbjerg, P. (2016). Novel DNPH-based method for determination of protein carbonylation in muscle and meat. Food Chemistry, 197, 670-675.

Shacter, E. (2000). Quantification and significance of protein oxidation in biological samples. Drug Metabolism Reviews, 32, 307-326.

Valcárcel-Yamani, B., \& da Silva, S.C. (2012). Applications of quinoa (Chenopodium quinoa Will.) and amaranth (Amaranthus Spp.) and their influence in the nutritional value of cereal based foods. Food and Public Health, 2(6), 265-275.

Yon, J. (1958). Influence des chlorures alcalins sur l'hydrolyse trypsique de la lactoglobuline native et dénaturée par la chaleur. Biochimica et Biophysica Acta, 27, 111-121.

Zhang, X., Lu, P., Xue, W., Wu, D., Wen, C., \& Zhou, Y. (2017). An evaluation of heat on protein oxidation of soy protein isolate or soy protein isolate mixed with soybean oil in vitro and its consequences on redox status of broilers at early age. Assia-Australasian 
Journal of Animal Sciences, 30(8), 1135-1142.

Zhang, W., Xiao, S., \& Ahn, D.U. (2013). Protein oxidation: basic principles and implications for meat quality. Critical reviews in food science and nutrition, 53(11), 1191-1201. 


\section{Summary}

The growing global population will place increased pressure on the world's resources to provide more proteins. It is expected that we need to switch at least partly from animals as sources of protein, to plant-based proteins, to ensure sufficient and sustainable production of proteins for everyone. Animal protein is nutritionally of very high quality, since it contains all essential amino acids, whereas vegetable sources generally lack one or more of the essential amino acids. However, this thesis shows that the image that plant proteins have an inferior amino acid profile and poor digestibility is not accurate. For instance, quinoa contains protein with an almost ideal amino acid profile. Especially the essential amino acids profile is considered to be wellbalanced for human nutrition. Besides, quinoa contains almost twice as much dietary fibre as most other grains and is high in phosphorus, magnesium and iron. In addition, the quinoa is a good source of calcium, which is useful for vegans and lactose intolerant people. The glutenfree nature of quinoa, being a non-cereal, is considered safe for celiac patients. Next to the amino acid profile including the essential amino acids, the digestibility is another important factor in determining the quality of a protein source. Generally, the potential use of plant proteins and thus also quinoa protein as a food ingredient is limited by their relatively lower digestibility as compared with animal proteins. However, this thesis shows that the reformulate digestibility can be improved by choosing a proper pre-treatment.

This thesis starts with a study on the effect of pre-treatment on in vitro gastric digestion of quinoa obtained via wet and dry fractionation (Chapter 2). Quinoa protein was isolated (QPI) from quinoa seeds using a wet fractionation method with a purity of $87 \%(\mathrm{w} / \mathrm{dw})$ and concentrated (QPC) via a dry fractionation method with a purity of $28 \%$ (w/dw). The dry fractionation process only involved milling and sieving and kept the protein in its natural, native state. The wet fractionation method affected the protein digestibility negatively in comparison to the dry fractionation method. In turn, heating decreased the protein digestibility of both types of quinoa. However, the effect of the temperature was lower in the QPC than in the QPI. The better digestibility of the QPC was attributed to the prevention of the formation of large aggregates during the heating of the protein.

The influence of heating on the denaturation and the digestibility properties of QPI obtained from a sweet quinoa variety at various extraction $\mathrm{pH}$ values was analysed in Chapter 3 . Heating the quinoa protein suspensions led to protein denaturation and aggregation, which was stronger at higher treatment temperatures. The protein digestibility was also lower when the protein 
dispersions had been heated at 90 and $120^{\circ} \mathrm{C}$ instead of $60{ }^{\circ} \mathrm{C}$, while the digestibility decreased with increasing extraction $\mathrm{pH}$. Both the effects of high temperature and of the extraction $\mathrm{pH}$ on the protein digestibility were ascribed to protein aggregation.

Chapter 4 extended the study from protein dispersions, towards protein gels. The type protein source (soy, pea, whey and albumin) and the temperature at which the protein is gelled into a semi-solid product, has great influence on the in vitro gastric protein digestibility. Gels formed at $140{ }^{\circ} \mathrm{C}$ digest faster as compared to gels induced at 90 and $120{ }^{\circ} \mathrm{C}$. It is thus clear that by adapting the gel morphology, one can also adapt the gastric digestibility of food products, which is not just a function of the source of the protein, but also very much on the structure of the food products, and on its processing history.

Dry milling and subsequent sieving of quinoa sweet varieties (Riobamba and Atlas) produced fractions that were enriched in protein and in starch (Chapter 5). This new dry fractionation method is a more resource efficient alternative to the conventional wet extraction of quinoa proteins and starch. The quinoa protein could be concentrated to a purity of around 32\% (32 $\mathrm{g} / 100 \mathrm{~g}$ dry solids) for both quinoa varieties analysed, while starch could be isolated to a fraction with a purity of $86-89 \%(86-89 \mathrm{~g} / 100 \mathrm{~g}$ dry solids). The protein yield and protein separation efficiency were higher for the Riobamba variety. The protein-enriched fraction is rich in oil and fibre as well. The proteins concentrated via the dry fractionation method proposed retained their native properties and showed a high water retention capacity and solubility when unheated. The gelatinization temperature of the starch-rich fraction was influenced by the residual presence of proteins. The starch isolation method had a pronounced effect on the pasting and textural properties. The protein-enriched fractions can be of relevance as functional food ingredients, with a high potential for application in gluten-free products.

The influence of starch and fibre on the in vitro gastric digestion of unheated and heated quinoa protein suspensions was studied in Chapter 6. The presence of either starch or fibre reduced the protein digestibility, which is explained by the lower accessibility of pepsin to hydrolyse the proteins, due to the swelling of these components. However, it was found that when fibre was added to a protein-starch system, the presence of fibre partially counteracted the reducing effect of starch on the protein digestibility. Therefore, there is a synergistic effect between the two that merits further study. The quinoa protein systems that had been heated at $120{ }^{\circ} \mathrm{C}$ showed reduced protein digestibility, which is due to the formation of large aggregates during preheating of the suspensions, as was also found in Chapter 2. 
In Chapter 7, it was found that heating does not affect the in vitro protein digestibility of SPI dispersions, while heating of PPC dispersions at $120{ }^{\circ} \mathrm{C}$ increased its protein digestibility, even though both protein types became partially insoluble. The soy protein isolate (SPI) and pea protein concentrate (PPC) dispersions were then separated into a soluble and an insoluble fraction to study the effect of heat-induced aggregation on protein digestibility. The insoluble fractions contained heat-induced aggregates and were less digestible than their soluble counterparts, which became more digestible with heating. This compensated for the relatively low digestibility of the insoluble fractions. Thus, the solubility of proteins is not always a prerequisite for protein digestion.

Finally, the main findings of this thesis were discussed and an outlook for further research was given around the major themes of this thesis (Chapter 8). The developments of a new separation process of plant proteins was discussed as well as the implications of the separation process on the protein functionality. A dry fractionation process for protein concentration of amaranth was presented. The possible effects of the protein isolation or concentration process were mentioned. Overall, three main conclusions could be drawn from this thesis.

1. Quinoa protein can be well isolated using conventional wet processes, yielding a QPI with good purity, but can also be concentrated using the new dry fractionation process. Both types of quinoa protein are well digestible according to the in vitro gastric assay that was used.

2. The conditions during processing of the raw materials into protein isolate or concentrate strongly influence the gastric digestibility: the thermal load, but also the $\mathrm{pH}$ applied during the isolation change the gastric digestion perhaps even stronger than the original differences between different protein sources.

3. The digestion of dissolved protein is relatively fast, while that of gelled protein is significantly slower; however the presence of other components such as starch or fibre slows the gastric digestion significantly down. This may be due to the lower amount of gastric fluid that is available for the protein, the lower swelling of the protein, and the subsequent slower indiffusion of pepsin into the protein matrix. 


\section{Acknowledgements}

It is pleasure to acknowledge the roles of several individuals who were instrumental for the completion of my $\mathrm{PhD}$ research.

First of all, I would like to acknowledge the CONICYT (National Commission for Scientific and Technological Research) for the fellowship granted to develop this thesis.

I would like to thank Anja, my daily supervisor, for our pleasant collaboration and introducing me to digestion research. Our weekly meeting always made me feel more positive about my thesis and with her valuable guidance, cheerful enthusiasm and ever-friendly nature, I was able to complete my research work in a respectable manner. I wish to express my gratitude for her support when I needed it, for teaching me how to write scientific papers, for helping me get back on track when I lost the overview and for correcting my papers. I am very grateful to my promotor Remko, for his personal support and especially for hearing me when I had a problem. Thank you for our meetings, which gave me a lot of new ideas and insights.

A special thanks goes to the students I was privileged to supervise during their BSc or MSc thesis. Didi, Zaira, Marte, Andrea, Danny, Zoë, Weijia and Tianhe, thank you all for your hard work and input. Also, my gratitude to my co-authors.

Also, I would like to thank my colleagues at the Food Process Engineering department, Patricia, Juliana, Dimitrios, Marlies, Qinhui, Konstantina, Elvira, Qi, Victor, Ali, Birgit, Anton, Jan-Eise, Meinou, Jaap, Eline, Zhaojun, Evelin, Anja, Jochem and Steven for the great moments. Big thanks to the technicians, Jos, Maurice, Martin and Jarno for helping me in the lab and to the secretaries, Marjan and Ilona, for helping me in everything that I needed.

Besides, I am grateful to my friends Nikolas, Daniela, Marcelo, Pamela, Begoña and Luis for their support outside work.

I cannot forget my family, Irma, Elda, Gladys, Omar, Melina and Vasia for their trust and support.

Finally, I would like to thank my patient and supportive wife, Grace, my son Facundo and my daughter Maite. I would have never reached this point of my life without you. Thank you for believing in me. 


\section{About the author}

Mauricio Alejandro Opazo Navarrete was born in Chillán, Chile, on October 9 1979. He finished his secondary education in 1997 at Liceo Narciso Tondreau in Chillán. In 1998 he started with the study Agricultural Civil Engineering at Universidad de Concepción. In 2006 he started with the study Food Engineering at Universidad del Bio Bio. He finished his study in 2010 and wrote his thesis titled "Elaboration and characterization of nanotubes made from bovine $\alpha$-lactalbumin". Subsequently, Mauricio started the MSc in Food Science and Engineering, which

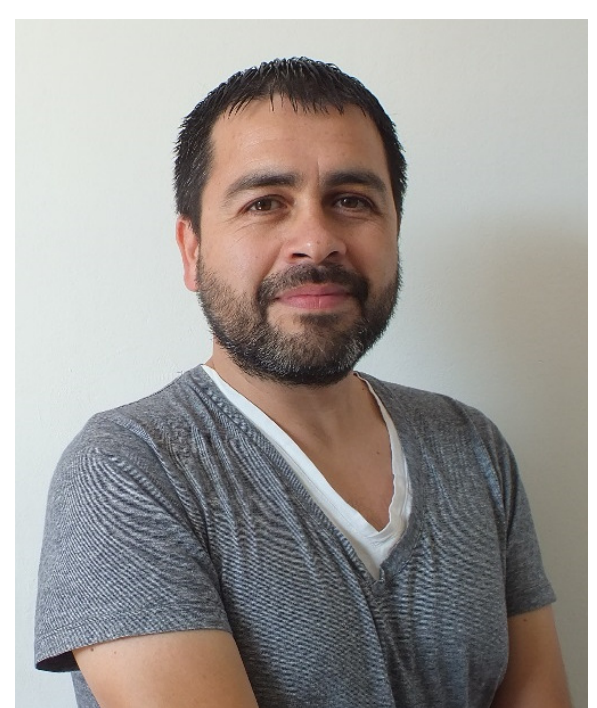
finalized in 2012. During his thesis, he studied the effects of high hydrostatic pressure on the rheological properties of Aloe vera gel. He wrote a thesis titled "Rheological characterization of Aloe vera (Aloe barbadensis Miller) gel treated with high hydrostatic pressure (HHP)".

In 2012 he went to La Calera, Chile, where started a position as Rendering Plant Manager in Sopraval. In 2013, he went to Santiago, Chile, where he started a position as Assistant Researcher in WageningenUR Chile. After some months, he was sent to Wageningen, The Netherlands to work in Food \& Biobased Research department.

In 2014, Mauricio started his $\mathrm{PhD}$ at the department of Food Process Engineering. He studied the effect of pre-treatments on the in vitro gastric digestibility of plant proteins with special emphasis on quinoa protein. The results from these four years of research are described in this thesis. 


\section{List of publications}

M. Opazo-Navarrete, D. Tagle Freire, R.M. Boom and A.E.M. Janssen. The influence of starch and fibre on in vitro protein digestibility of dry fractionated quinoa seed (Riobamba variety). Submitted for publication.

M. Opazo-Navarrete, A. Rivera del Rio, R.M. Boom, A.E.M. Janssen. In vitro gastric digestibility of soy and pea proteins un relation to their aggregation behaviour. Submitted for publication.

Yamira Cepero-Betancourt, Anja E.M. Janssen, Mauricio Opazo-Navarrete, Mario PérezWon. Changes in protein structure and digestibility of abalone treated by high hydrostatic pressure. Submitted for publication.

M. Opazo-Navarrete, D. Tagle Freire, R.M. Boom, A.E.M. Janssen, M.A.I. Schutyser. Dry fractionation of quinoa sweet varieties Atlas and Riobamba for sustainable production of protein and starch fractions. Journal of Food Composition and Analysis, 74, 95-101.

Mauricio Opazo-Navarrete, Marte Altenburg, Remko M. Boom, A.E.M. Janssen (2018). The effect of gel microstructure on simulated gastric digestion of protein gels. Food Biophysics, 13, 124-138.

M. Opazo-Navarrete, M.A.I. Schutyser, R.M. Boom, A.E.M. Janssen. (2017). Effect of pretreatment on in vitro gastric digestion of quinoa protein (Chenopodium quinoa Willd.) obtained by wet and dry fractionation. International Journal of Food Sciences and Nutrition, 69(1), 111.

Wei-Chun Fu, Mauricio A. Opazo, Sergio M. Acuña, Pedro G. Toledo. (2017). New route for self-assembly of $\alpha$-lactalbumin nanotubes and their use as templates to grow silver nanotubes. PLoS ONE 12(4): e0175680.

Geraldine Avila Ruiz, Mauricio Opazo-Navarrete, Marlon Meurs, Marcel Minor, Guido Sala, Martinus van Boekel, Markus Stiege and Anja E.M. Janssen. (2016). Denaturation and in vitro gastric digestion of heat-treated quinoa protein isolates obtained at various extraction $\mathrm{pH}$. Food Biophysics, 11: 184-197. 


\section{Overview of completed training activities}

\section{Discipline specific activities}

Sustainability Analysis in Food and Biobased Production (NL) 2014

Reaction Kinetics in Food Science (NL) 2014

$\begin{array}{ll}\text { Advanced Proteomics (NL) } & 2015\end{array}$

$\begin{array}{ll}\text { Advanced Food Analysis (NL) } & 2015\end{array}$

$4^{\text {th }}$ International Conference on Food Digestion (IT) ${ }^{\mathrm{a}} 2015$

II Jornada Chilena de Investigadores Chilenos en Europa (ES) ${ }^{\mathrm{b}} 2015$

Food Proteins: Significance, Reactions and Modifications (DEN) 2016

$18^{\text {th }}$ World Congress of Food Science and Technology, IUFOST (IR) ${ }^{\mathrm{a}} \quad 2016$

$\begin{array}{ll}\text { Proteins for Life (NL) } & 2016\end{array}$

$\begin{array}{ll}\text { Encuentros Barcelona (ES) } & \text { ab } \\ & 2016\end{array}$

5th International Conference on Food Digestion (FR) ${ }^{\mathrm{a}} 2017$

VIII Encuentro Científico Internacional del Norte (PE) ${ }^{\mathrm{b}}$

Congreso Iberoamericano de Ingeniería en Alimentos, CIBIA XI (CL) ${ }^{\mathrm{b}} \quad 2017$

\section{General courses / activities}

$\begin{array}{ll}\text { VLAG PhD Week (NL) } & 2014\end{array}$

Techniques for Writing and Presenting a Scientific Paper (NL) 2015

Teaching and Supervising Thesis Students (NL) 2016

$\begin{array}{ll}\text { Scientific Writing (NL) } & 2016\end{array}$

$\begin{array}{ll}\text { Presenting with Impact (NL) } & 2016\end{array}$ 


\section{Optional activities}

Preparation of Research Proposal (NL) 2014

Food Process Engineering Brainstorm Days (NL) ${ }^{\mathrm{ab}}$ 2014-2018

PhD Study tour Germany and Switzerland (GE and SW) $)^{\text {ab }}$ 2014-2018

${ }^{a}$ Poster presentation

${ }^{\mathrm{b}}$ Oral presentation

Abbreviations: The Netherlands (NL), Italy (IT), Spain (ES), Denmark (DEN), Ireland (IR), France (FR), Peru (PE), Chile (CL), Germany (GE), Switzerland (SW). 
The research described in this thesis was financially supported by the Graduate School VLAG. This thesis is printed by Digiforce I I ProefschriftMaken in 150 copies.

Cover design: Luisa Mariana Rocha Criollo. 


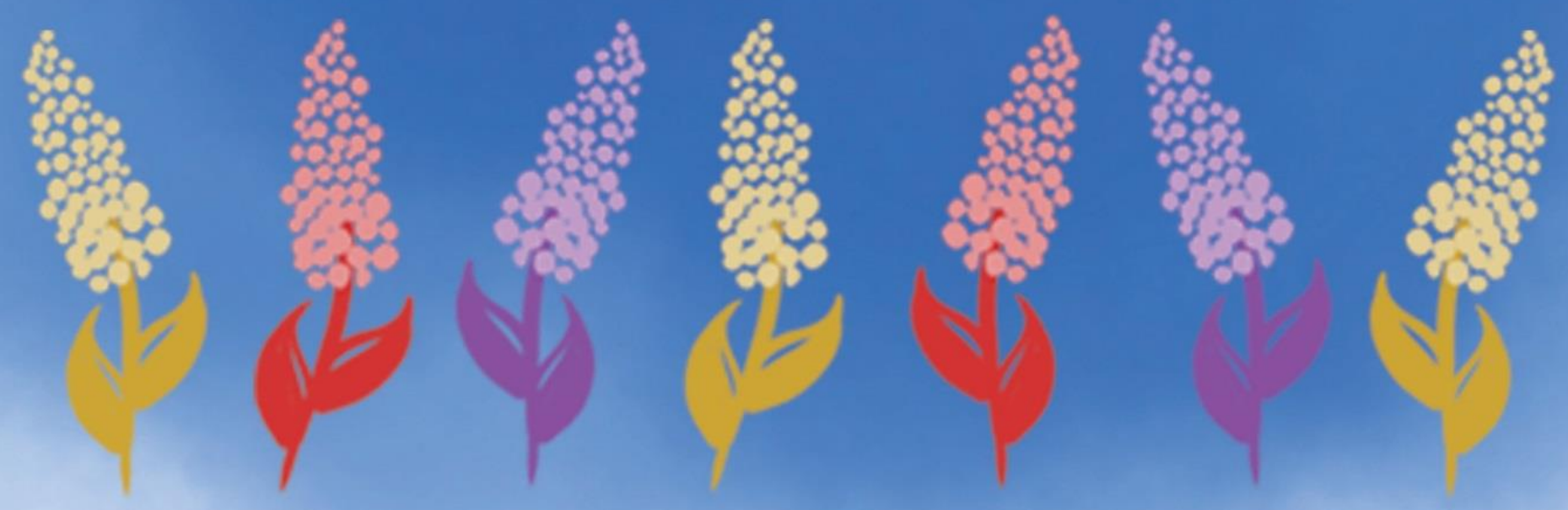

